\title{
Syntheses of azepinoindole alkaloids cimitrypazepine, fargesine and hyrtioreticulins C \& D
}

\author{
Ganesh Ghimire \\ West Virginia University, gghimire@mail.wvu.edu
}

Follow this and additional works at: https://researchrepository.wvu.edu/etd

Part of the Organic Chemistry Commons

\section{Recommended Citation}

Ghimire, Ganesh, "Syntheses of azepinoindole alkaloids cimitrypazepine, fargesine and hyrtioreticulins C \& D" (2018). Graduate Theses, Dissertations, and Problem Reports. 3745.

https://researchrepository.wvu.edu/etd/3745

This Dissertation is protected by copyright and/or related rights. It has been brought to you by the The Research Repository @ WVU with permission from the rights-holder(s). You are free to use this Dissertation in any way that is permitted by the copyright and related rights legislation that applies to your use. For other uses you must obtain permission from the rights-holder(s) directly, unless additional rights are indicated by a Creative Commons license in the record and/ or on the work itself. This Dissertation has been accepted for inclusion in WVU Graduate Theses, Dissertations, and Problem Reports collection by an authorized administrator of The Research Repository @ WVU.

For more information, please contact researchrepository@mail.wvu.edu. 


\title{
Syntheses of azepinoindole alkaloids cimitrypazepine, fargesine and hyrtioreticulins C \& D
}

\author{
Ganesh Ghimire \\ Dissertation submitted \\ to the Eberly College of Arts and Sciences \\ at West Virginia University
}

in partial fulfillment of the requirements for the degree of

Doctor of Philosophy in

Chemistry

\author{
Björn C. G. Söderberg, Ph.D., Chair \\ Jeffrey L. Petersen, Ph.D \\ Kung K. Wang, Ph.D. \\ Brian V. Popp, Ph.D. \\ Patrick Callery, Ph.D.
}

C. Eugene Bennett Department of Chemistry

\section{Morgantown, West Virginia}

2018

Keywords: indole, cimitrypazepine, fargesine, hyrtioreticulins, intramolecular Heck reaction, palladium-catalyzed

Copyright 2018 Ganesh Ghimire 


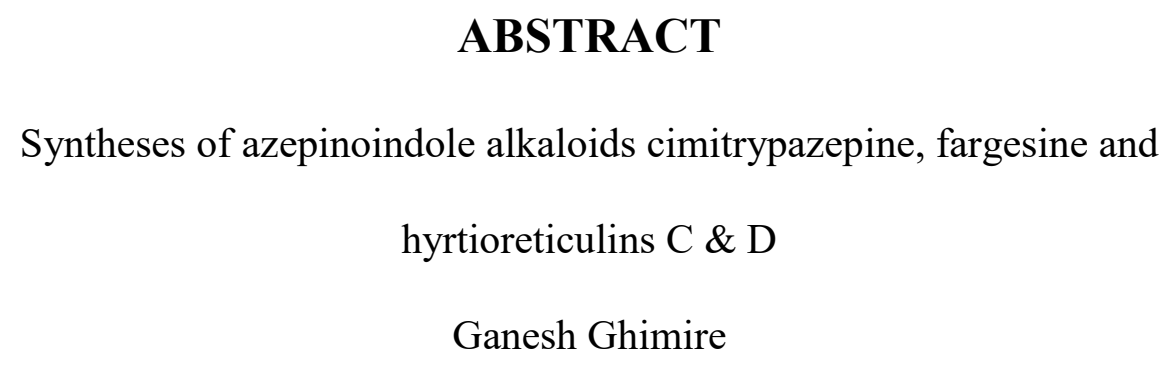

The Watanabe-Cenini-Söderberg reductive $N$-heterocyclization has emerged as a powerful tool for the synthesis of a variety of functionalized indoles. Söderberg's elaboration of this methodology has been utilized as a late-stage cyclization protocol for the synthesis of azepinoindole alkaloids, a class of natural products characterized by an azepane skeleton fused with an indole ring. Short syntheses of the naturally occurring azepino[5,4,3-cd]indole alkaloids, cimitrypazepine, fargesine, and the diastereomeric hyrtioreticulins C \& D have been completed starting from commercially available tetra-substituted benzene derivatives. The key azepinoindole core in each case was assembled via an intramolecular Mizoroki-Heck reaction followed by a Watanabe-Cenini-Söderberg reductive $N$-heterocyclization. Synthesis of aurantioclavine using a similar strategy is currently underway. 


\section{Acknowledgements}

I would like to thank my research advisor, Dr. Bjorn Söderberg, for his support, mentorship and friendship during my time in his research group. The experience of being a graduate student in his research lab has been the most fruitful days of my life. His profound knowledge, valuable insight and helpful guidance, support and encouragement throughout the course of my research were the key elements for the completion of this work. I admire his professional spirit and energy, and extreme patience especially at times when success seemed far from me.

I would like to thank Dr. Jeffrey Petersen, Dr. Kung Wang and Dr. Brian Popp for their valuable time serving as my committee members. I would also like to thank Patrick Callery from health science for serving as an external member on my research committee. In addition, I am very much indebted to the wonderful teachers of WVU Chemistry, particularly Dr. John Penn and Dr. Michelle Richards-Babb for their help and support.

Much appreciation is extended to Dr. Novruz Akhmedov for maintaining the NMR facilities and for helping me run and analyze my samples. Dr. Akhmedov's NMR expertise was vital at numerous points of my graduate work.

I would also like to thank my fellow research group members, both past and present, for their support and companionship. I owe many thanks to my senior Dr. Matthew Cummings for his advice and support. My deepest gratitude goes to Dr. Katharine Lambson who was always there for me to help.

I am grateful to Albert Taylor, Jr., Barbara Foster, Rebecca Secrist, Brenda Prentiss and Michael Torries for their constant help and support throughout my time in the department. 
I would like to acknowledge the National Institutes of Health (NIH 1 R15 GM12202201) for research funding, and Eberly College of Arts and Sciences, C. Eugene Bennett Department of Chemistry and WVU Academic Affairs for travel support.

Most importantly, I would like to thank my parents, who always worked hard for my good education. I am very thankful to my darling my wife, Ganga for all her endless love, support, and understanding throughout our difficult past few years. My special thanks go to my daughter Sejal for being such a caring and understanding daughter in the family; and to Pranjal and Prabal for welcoming me home with your smiling face when I returned late from lab. I apologize to you and your mom for not being able to give proper time for family due to long days in lab, but it is all over now. Last but not least, I would like to thank my brother, Dinesh for his support and encouragement. 


\section{Table of Contents}

Title Page $\quad$ i

$\begin{array}{ll}\text { Abstract } & \text { ii }\end{array}$

$\begin{array}{ll}\text { Acknowledgements } & \text { iii }\end{array}$

Table of Contents $\quad$ V

List of Figures viii

List of Schemes $\quad$ xiii

\section{Chapter 1}

Introduction to Indole and Azepinoindole, Strategies Towards the Synthesis of Azepinoindoles

1.1 Introduction of Indole 2

1.2 Watanabe-Cenini-Söderberg Reductive $N$-Heterocyclization $\quad 4$

1.3 3,4-Fused Azepinoindoles 5

1.4 Strategies Towards the Synthesis of Azepino[5,4,3-cd]indoles $\quad 7$

1.4.1 Synthesis via 'a' Bond Formation 8

1.4.2 Synthesis via ' $b$ ' Bond Formation 9

$\begin{array}{ll}\text { 1.4.3 Synthesis via 'c' Bond Formation } & 12\end{array}$

1.4.4 Cyclization at 3-Position of Indole 13

1.4.5 Synthesis via Sequential 'e' and 'f' or 'b', 'e' and 'f' Bond Formation 15 


\section{Chapter 2}

\section{Short Syntheses of Cimitrypazepine and Fargesine}

2.1 Introduction to Cimitrypazepine and Fargesine 19

2.2 Literature Syntheses of Cimitrypazepine and Fargesine 19

2.2.1 Nikolić's Synthesis of Cimitrypazepine 19

2.2.2 Jia's Synthesis of Fargesine 20

2.2.3 Nemoto's Synthesis of Cimitrypazepine and Fargesine 21

2.3 Short Syntheses of Cimitrypazepine and Fargesine 22

2.3.1 Retrosynthetic Analysis 22

$\begin{array}{ll}\text { 2.3.2 Results and Discussion } & 23\end{array}$

2.4 Conclusions 28

\section{Chapter 3}

\section{Syntheses of Hyrtioreticulins C \& D}

3.1 Introduction to Hyrtioreticulins C \& D 30

3.2 Previous Syntheses of Hyrtioreticulins C \& D 31

3.2.1 Abe and Yamada Synthesis 31

3.3 Total Syntheses of Hyrtioreticulins C \& D 31

3.3.1 Retrosynthetic Analysis 32

3.3.2 Results and Discussion 33

3.4 Conclusions $\quad 41$ 


\section{Chapter 4}

\section{Attempted Synthesis of Aurantioclavine}

4.1 Introduction to Aurantioclavine

4.2 Notable Syntheses of Aurantioclavine

4.2.1 First Synthesis by Somei

4.2.2 First Enantioselective Synthesis by Stoltz

4.2.3 Most Recent Synthesis by Takemoto

4.3 Attempted Synthesis of Aurantioclavine

4.3.1 Retrosynthetic Analysis

\section{Chapter 5}

\section{Supporting Information: Experimental Procedures}

7.1 Supporting Information for Chapter 2: Cimitrypazepine and Fargesine

7.2 Supporting Information for Chapter 3: Hyrtioreticulins C \& D

References and Notes

\section{Appendix}

\section{${ }^{1} \mathrm{H}$ and ${ }^{13} \mathrm{C}$ NMR Spectra}

- ${ }^{1} \mathrm{H}$ and ${ }^{13} \mathrm{C}$ NMR for Chapter 2: Cimitrypazepine and Fargesine

- $\quad{ }^{1} \mathrm{H}$ and ${ }^{13} \mathrm{C}$ NMR for Chapter 3: Hyrtioreticulins C \& D 


\section{List of Figures}

Figure 1: Structure and Numbering of Indole 2

Figure 2: Indole Containing Drugs and Chemicals 2

Figure 3: Naming of Azepinoindoles $\quad 6$

Figure 4: Naturally Occurring azepino $[5,4,3-c d]$ indoles $\quad 6$

Figure 5: Ring Disconnections Employed in Syntheses of Naturally Occurring 8 Azepino $[5,4,3-c d]$ indoles

Figure 6: Structure of $N$-oxide Indole Alkaloids from Evodia fargesii 19

Figure 7: Hyrtioreticulins A-F Isolated from Hyrtios reticulatus 30

Figure 8: Structural Relationship of Aurantioclavine with Communesins 43

Figure 9: ${ }^{1} \mathrm{H}$ NMR of Compound 95

Figure 10: ${ }^{13} \mathrm{C}$ NMR of Compound 95

Figure 11: ${ }^{1} \mathrm{H}$ NMR of Compound 97

Figure 12: ${ }^{13} \mathrm{C}$ NMR of Compound 97

Figure 13: ${ }^{1} \mathrm{H}$ NMR of Compound 98

Figure 14: ${ }^{13} \mathrm{C}$ NMR of Compound 98

Figure 15: ${ }^{1} \mathrm{H}$ NMR of Compound $\mathbf{1 0 1} 97$

Figure 16: ${ }^{13} \mathrm{C}$ NMR of Compound 101

Figure 17: ${ }^{1} \mathrm{H}$ NMR of Compound $\mathbf{1 0 2} 99$

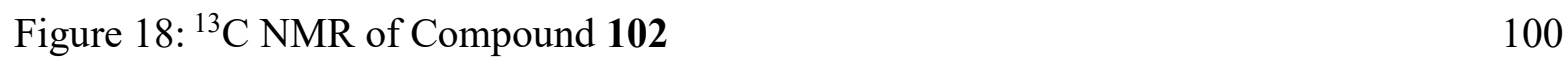

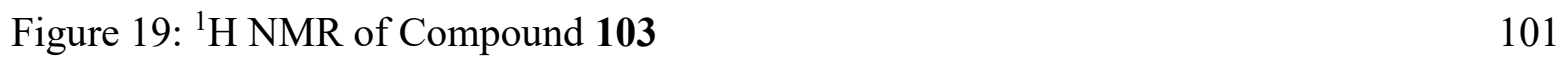


Figure 20: ${ }^{13} \mathrm{C}$ NMR of Compound $\mathbf{1 0 3}$

Figure 21: ${ }^{1} \mathrm{H}$ NMR of Compound 104

103

Figure 22: ${ }^{13} \mathrm{C}$ NMR of Compound 104

104

Figure 23: ${ }^{1} \mathrm{H}$ NMR of Compound 105

105

Figure 24: ${ }^{13} \mathrm{C}$ NMR of Compound 105

106

Figure 25: ${ }^{1} \mathrm{H}$ NMR of Compound 106

107

Figure 26: ${ }^{13} \mathrm{C}$ NMR of Compound 106

108

Figure 27: ${ }^{1} \mathrm{H}$ NMR of Compound $\mathbf{8 8}$

109

Figure 28: ${ }^{13} \mathrm{C}$ NMR of Compound $\mathbf{8 8}$

110

Figure 29: ${ }^{1} \mathrm{H}$ NMR of Compound 107

Figure 30: ${ }^{13} \mathrm{C}$ NMR of Compound 107

112

Figure 31: ${ }^{1} \mathrm{H}$ NMR of Compound 127

113

Figure 32: ${ }^{13} \mathrm{C}$ NMR of Compound $\mathbf{1 2 7}$

114

Figure 33: ${ }^{1} \mathrm{H}$ NMR of Compound 128

115

Figure 34: ${ }^{13} \mathrm{C}$ NMR of Compound 128

116

Figure 35: ${ }^{13} \mathrm{C}$ NMR of Compound 128

117

Figure 36: COSY of Compound 128

118

Figure 37: ${ }^{1} \mathrm{H}$ NMR of Compound 136

119

Figure 38: ${ }^{13} \mathrm{C}$ NMR of Compound $\mathbf{1 3 6}$ 120

Figure 39: ${ }^{1} \mathrm{H}$ NMR of Compound 137

Figure 40: ${ }^{13} \mathrm{C}$ NMR of Compound 137

122

Figure 41: ${ }^{1} \mathrm{H}$ NMR of Compound 138 123

Figure 42: ${ }^{13} \mathrm{C}$ NMR of Compound 138 
Figure 43: ${ }^{1} \mathrm{H}$ NMR of Compound $\mathbf{1 4 0}$ racemic mixture

Figure $44:{ }^{13} \mathrm{C}$ NMR of Compound 140 racemic mixture

126

Figure 45: ${ }^{1} \mathrm{H}$ NMR of Compound $\mathbf{1 4 0}$ single isomer

127

Figure 46: ${ }^{13} \mathrm{C}$ NMR of Compound 140 single isomer

128

Figure 47: ${ }^{1} \mathrm{H}$ NMR of Compound 142

Figure 48: ${ }^{13} \mathrm{C}$ NMR of Compound $\mathbf{1 4 2}$

130

Figure 49: ${ }^{1} \mathrm{H}$ NMR of Compound 143

131

Figure 50: ${ }^{13} \mathrm{C}$ NMR of Compound $\mathbf{1 4 3}$

Figure 51: ${ }^{1} \mathrm{H}$ NMR of Compound 144

133

Figure 52: ${ }^{13} \mathrm{C}$ NMR of Compound $\mathbf{1 4 4}$ 134

Figure 53: ${ }^{1} \mathrm{H}$ NMR of Compound 145 135

Figure 54: ${ }^{13} \mathrm{C}$ NMR of Compound $\mathbf{1 4 5}$ 136

Figure 55: ${ }^{1} \mathrm{H}$ NMR of Compound 146

Figure 56: ${ }^{13} \mathrm{C}$ NMR of Compound 146

138

Figure 57: ${ }^{1} \mathrm{H}$ NMR of Compound 147

Figure 58: ${ }^{13} \mathrm{C}$ NMR of Compound 147

140

Figure 59: ${ }^{1} \mathrm{H}$ NMR of Compound 149 141

Figure 60: ${ }^{13} \mathrm{C}$ NMR of Compound 149 142

Figure 61: ${ }^{1} \mathrm{H}$ NMR of Compound 150 143

Figure 62: ${ }^{13} \mathrm{C}$ NMR of Compound 150 144

Figure 63: ${ }^{1} \mathrm{H}$ NMR of Compound $\mathbf{1 5 2}$ 145

Figure 64: ${ }^{13} \mathrm{C}$ NMR of Compound 152 146

Figure 65: ${ }^{1} \mathrm{H}$ NMR of Compound $\mathbf{1 5 3}$

147 
Figure 66: ${ }^{13} \mathrm{C}$ NMR of Compound $\mathbf{1 5 3}$

Figure 67: ${ }^{1} \mathrm{H}$ NMR of Compound 154

149

Figure 68: ${ }^{13} \mathrm{C}$ NMR of Compound $\mathbf{1 5 4}$

Figure 69: ${ }^{1} \mathrm{H}$ NMR of Compound 155

151

Figure 70: ${ }^{13} \mathrm{C}$ NMR of Compound 155

152

Figure 71: ${ }^{1} \mathrm{H}$ NMR of Compound 158

Figure 72: ${ }^{13} \mathrm{C}$ NMR of Compound 158

154

Figure 73: ${ }^{1} \mathrm{H}$ NMR of Compound 159 155

Figure 74: ${ }^{13} \mathrm{C}$ NMR of Compound 159 156

Figure 75: ${ }^{1} \mathrm{H}$ NMR of Compound 160 157

Figure 76: ${ }^{13} \mathrm{C}$ NMR of Compound 160 158

Figure 77: ${ }^{1} \mathrm{H}$ NMR of Compound 161 159

Figure 78: ${ }^{13} \mathrm{C}$ NMR of Compound 161 160

Figure 79: ${ }^{1} \mathrm{H}$ NMR of Compound 164 161

Figure 80: ${ }^{13} \mathrm{C}$ NMR of Compound $\mathbf{1 6 4}$ 162

Figure 81: ${ }^{1} \mathrm{H}$ NMR of Compound 165

163

Figure 82: ${ }^{13} \mathrm{C}$ NMR of Compound $\mathbf{1 6 5}$ 164

Figure 83: ${ }^{1} \mathrm{H}$ NMR of Compound 200 165

Figure 84: ${ }^{13} \mathrm{C}$ NMR of Compound 200 166

Figure 85: ${ }^{1} \mathrm{H}$ NMR of Compound 201 167

Figure 86: ${ }^{13} \mathrm{C}$ NMR of Compound 201 168

Figure 87: ${ }^{1} \mathrm{H}$ NMR of Compound 203 169

Figure 88: ${ }^{13} \mathrm{C}$ NMR of Compound 203 170 
Figure 89: ${ }^{1} \mathrm{H}$ NMR of Compound 205

Figure 90: ${ }^{1} \mathrm{H}$ NMR of Compound $\mathbf{2 0 5} 172$

Figure 91: ${ }^{1} \mathrm{H}$ NMR of Compound 205

Figure 92: ${ }^{13} \mathrm{C}$ NMR of Compound $205 \quad 174$

$\begin{array}{ll}\text { Figure 93: COSY of Compound } 205 & 175\end{array}$

Figure 94: HSQC of Compound $205 \quad 176$

Figure 95: NOE of Compound 205

$\begin{array}{lr}\text { Figure 96: NOE of Compound } 205 & 178\end{array}$

$\begin{array}{ll}\text { Figure 97: NOE of Compound } 205 & 179\end{array}$

$\begin{array}{lr}\text { Figure 98: HMBC of Compound } 205 & 180\end{array}$

$\begin{array}{ll}\text { Figure 99: HMBC of Compound } 205 & 181\end{array}$

Figure 100: HMBC of Compound $\mathbf{2 0 5} \quad 182$ 


\section{List of Schemes}

Scheme 1: Biosynthesis of Melatonin 3

Scheme 2: Watanabe and Söderberg Reductive Heterocyclization 4

Scheme 3: Söderberg Reductive $N$-Heterocyclization Optimized for Late-Stage 5

Indolization in Natural Products Synthesis

Scheme 4: Synthesis of Clavicipitic Acid by Bartoccini et al. 8

Scheme 5: Syntheses using a Pictet-Spengler Reaction

Scheme 6: Xu's Synthesis of Clavicipitic Acid 10

Scheme 7: Synthesis of Hyrtiazepine by Ito et al. 10

Scheme 8: Synthesis of Clavicipitic Acid by Tahara et al. 11

Scheme 9: Liu's Synthesis of Clavicipitic Acid 12

Scheme 10: Synthesis of Aurantioclavine by Stoltz et al. 12

Scheme 11: Synthesis of Aurantioclavine by Ellman et al. 13

Scheme 12: Chiral Phosphoric Acid Catalyzed Cyclization 13

Scheme 13: Indium Triflate Catalyzed Cyclization 14

Scheme 14: Iridium Catalyzed Cyclization $\quad 15$

Scheme 15: Intramolecular Larock Indole Synthesis 15

Scheme 16: Söderberg's Sequential Cyclization Strategy 16

Scheme 17: Nemoto’s Synthesis of Fargesine 17

Scheme 18: Biomimetic Synthesis of Cimitrypazepine 20

Scheme 19: Jia’s Synthesis of Fargesine $\quad 20$

Scheme 20: Nemoto’s Synthesis of Cimitrypazepine and Fargesine 21

Scheme 21: Proposed Retrosynthetic Outline for Cimitrypazepine and Fargesine 23 
Scheme 22: Reductive Amination of 6-Hydroxy-2-iodo-3-nitrobenzaldehyde 94

Scheme 23: Synthesis of $O$-Boc and $N$-Boc Protected Amines 97 and 98

Scheme 24: Synthesis of 2-Benzazepines 101 and 102 and Benzazocines 103 and $104 \quad 26$

Scheme 25: N-Heterocyclization and Reduction to Give Cimitrypazepine 88

$\begin{array}{ll}\text { Scheme 26: Synthesis of Fargesine } 87 & 28\end{array}$

Scheme 27: First Synthesis of Hyrtioreticulins C \& D 31

Scheme 28: Proposed Retrosynthetic Outline for Hyrtioreticulins 32

Scheme 29: Indirect Reductive Amination to Form 127

Scheme 30: Undesired Cyclization of $\mathbf{1 2 7} 34$

Scheme 31: Revised Retrosynthetic Outline for Hyrtioreticulins 35

Scheme 32: Nitration of 2-Hydroxy-6-methoxyacetophenone 35

Scheme 33: Trans-imination of 2-Hydroxy-6-methoxy-3-nitro acetophenone with L- 36

Allylglycine Methyl Ester

Scheme 34: Triflation of Racemic Phenol 140

$\begin{array}{ll}\text { Scheme 35: Synthesis of 2-Benzazepines } 144 \text { and } 145 & 37\end{array}$

Scheme 36: $N$-Heterocyclization to Give Azepinoindoles 146 and 147

Scheme 37: Nitration of 2-Hydroxy-6-benzylacetophenone 38

Scheme 38: Trans-imination and Triflation to Give $\mathbf{1 5 4}$ and $\mathbf{1 5 5} 39$

Scheme 39: Intramolecular Mizoroki-Heck Reaction and Reductive $N-$

Heterocyclization

Scheme 40: Synthesis of Hyrtioreticulins C \& D 40

Scheme 41: Somei's Synthesis of Aurantioclavine 44

Scheme 42: Stoltz Synthesis of Aurantioclavine 45 
Scheme 43: Concise and Scalable Synthesis by Takemoto

Scheme 44: Proposed Retrosynthetic Outline for Aurantioclavine

Scheme 45: Aldol Reaction and Dehydration of Aldol Product

Scheme 46: Protection of Phenol Using PMBCl

Scheme 47: Reductive Amination of Ketone 203 


\section{Chapter 1}

\section{Introduction to Indole and Azepinoindole, Strategies Towards Azepinoindoles}

$\begin{array}{ll}1.1 \text { Introduction of Indole } & 2\end{array}$

1.2 Watanabe-Cenini-Söderberg Reductive $N$-Heterocyclization 4

1.3 3,4-Fused Azepinoindoles 5

1.4 Strategies Towards the Synthesis of Azepino[5,4,3-cd]indoles $\quad 7$

1.4.1 Synthesis via 'a' Bond Formation $\quad 8$

1.4.2 Synthesis via ' $b$ ' Bond Formation 9

$\begin{array}{ll}\text { 1.4.3 Synthesis via 'c' Bond Formation } & 12\end{array}$

$\begin{array}{lll}\text { 1.4.4 Cyclization at 3-Position of Indole } & 13\end{array}$

1.4.5 Synthesis via Sequential 'e' and 'f'or ' $b$ ', 'e' and ' $\mathrm{f}$ ' Bond Formation 15 


\subsection{Introduction of Indole}

Indole (1), also called benzopyrrole, is an aromatic heterocyclic compound in which a pyrrole ring is fused to a benzene ring (Figure 1).

Figure 1: Structure and Numbering of Indole

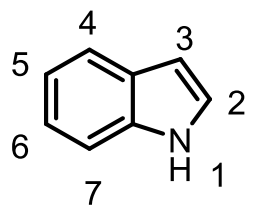

1

After their discovery in 1860's by Baeyer and coworkers, ${ }^{1}$ indole-based compounds are perhaps the most highly studied organic molecules due to their widespread application in industries, pharmaceuticals, agrochemicals, dyes, perfumes and dietary supplements (Figure 2). ${ }^{2}$ Indoles are considered 'Privileged structures' in drug discovery as they are capable of binding to multiple receptors with high affinity..$^{3,4}$

\section{Figure 2: Indole Containing Drugs and Chemicals}

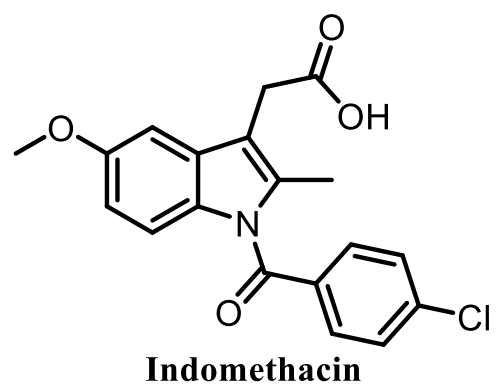

Non-steroidal anti-inflammatory drug

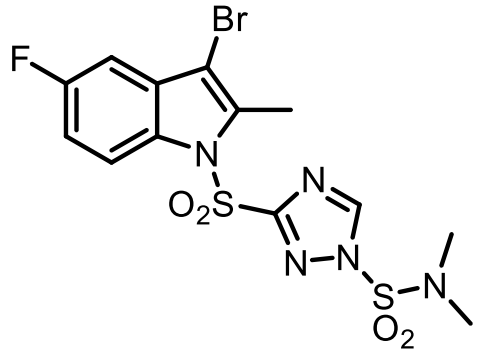

Amisulbrom

Plant fungicide 


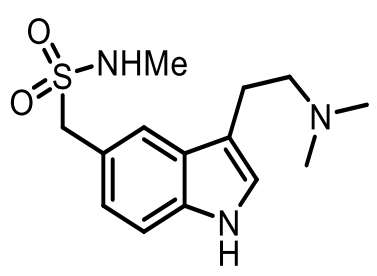

Sumtriptan Anti-migraine drug

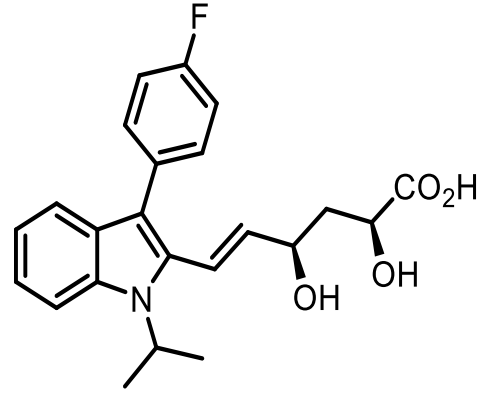

Fluvastatin Hypercholesterolemia medicine

The interest in indole chemistry was more intensified after 1930's when it was discovered that many natural products and bioactive molecules contain indoles as their core structures. The indole nucleus is embedded in many biological systems including the essential amino acid tryptophan, the neurotransmitter serotonin, and the mammalian hormone melatonin. Tryptophan is a structural constituent of many proteins as well as the biosynthetic precursor of serotonin, which in turn serves as the precursor of melatonin (Scheme 1). Serotonin plays a critical role in neuronal cell formation and maintenance, sleep, cognition, appetite, and mood, whereas melatonin is a natural bioregulator that induces and maintains sleep. ${ }^{5,6}$

\section{Scheme 1: Biosynthesis of Melatonin}

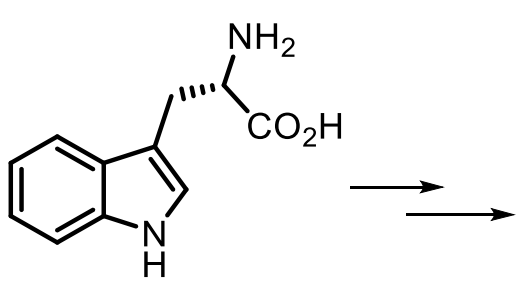

Tryptophan Essential amino acid<smiles>NCCc1c[nH]c2ccc(O)cc12</smiles>

Serotonin Neurotransmitter

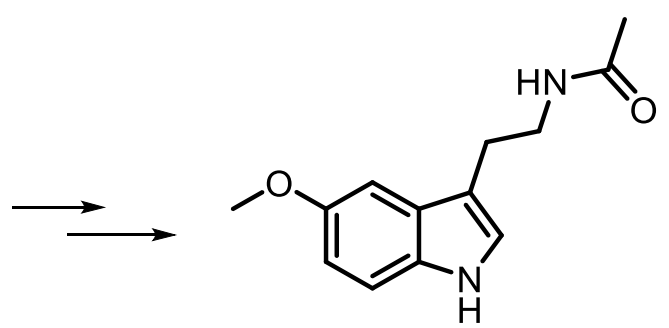

Melatonin Neurohormone

Tryptophan is also the biogenetic precursor of many indole alkaloids. Naturally occurring indole alkaloids are constantly getting more attention from the scientific community due to their intriguing structure and biological activity. Many endeavors are driven by structural complexity 
and their potential as drug candidates. Development of advanced isolation and characterization techniques has made their investigation convenient. As a result, many new indole alkaloids are reported annually. Synthetic attempts toward these complex indole structures may lead to reaction discovery and development. A number of methods have been reported as established routes for the preparation of indole and its analogs. ${ }^{7}$ Among the synthetic routes, there are quite a few transition metal- catalyzed or -mediated methods of indole synthesis. ${ }^{8,9,10}$ Among the plethora of methodologies used for indole synthesis, the Watanabe-Cenini- Söderberg reductive $N$-heterocyclization ${ }^{11}$ has emerged as a powerful tool for indole synthesis, which will be discussed in the following section.

\subsection{Watanabe-Cenini- Söderberg Reductive $N$-Heterocyclization}

Although first discovered by Watanabe, ${ }^{12}$ the reductive $N$-heterocyclization of $o$ nitrostyrenes to give indoles was extensively elaborated by Söderberg group establishing the methodology as a powerful synthetic method (Scheme 2). Although not unprecedented, the Söderberg method provides a number of significant improvements over previously reported conditions such as low temperature, mild reaction conditions and ease of work-up, because the only by-product formed is carbon dioxide. ${ }^{13}$

\section{Scheme 2: Watanabe and Söderberg Reductive Heterocyclization}

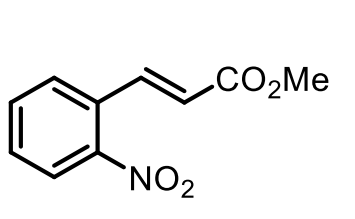

2

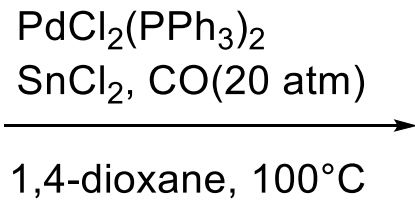

1,4-dioxane, $100^{\circ} \mathrm{C}$

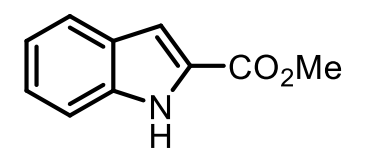

3 

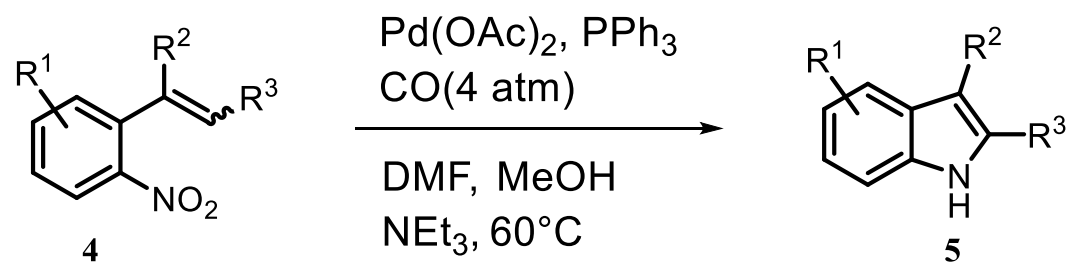

Söderberg's method has been successfully applied to the synthesis of a number of indole analogs including tryptophan derivatives, ${ }^{14}$ bicyclic heteroaromatics, ${ }^{15}$ carbazole alkaloids, ${ }^{16}$ mushroom metabolites, ${ }^{17}$ and various natural products. ${ }^{18-25}$ Through a detailed optimization study of the reaction conditions, it was observed that the $\mathrm{Pd}(\mathrm{dba})_{2}$-dppp-1,10-phenanthroline system using DMF as solvent at $120{ }^{\circ} \mathrm{C}$ under 6 atm of carbon monoxide (Scheme 3) was highly applicable to late stage indolization during many natural products syntheses. ${ }^{22-25}$

Scheme 3: Söderberg Reductive $N$-Heterocyclization Optimized for Late Stage Indolization in Natural Products Synthesis

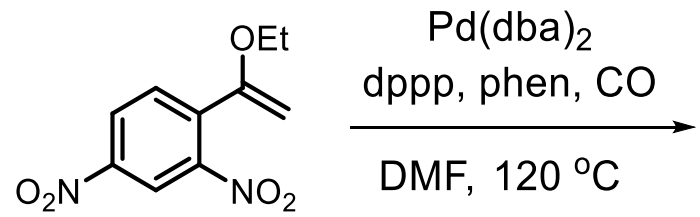

6<smiles>CCOc1c[nH]c2cc([N+](=O)[O-])ccc12</smiles>

7

\subsection{3,4-Fused Azepinoindoles}

Azepinoindoles refer to the organic compounds in which a seven-membered ring containing nitrogen is fused with indole core. Azepinoindoles fused at 1,2-, 2,3- and 3,4- position of the pyrrole ring have been reported. Azepinoindoles are named according to the following scheme based on the fusion position of the azepine-ring with indole. ${ }^{26}$ The nitrogen atom of the azepine ring is designated atom 1 and proceeds towards the pyrrole portion of the molecule 
(Figure 3). The bonds in the pyrrole ring are named a, b, c and d to indicate where the azepine ring is fused. The numbering of fused atoms starts from the number of the atom closest to the pyrrole nitrogen.

\section{Figure 3: Naming of Azepinoindoles}

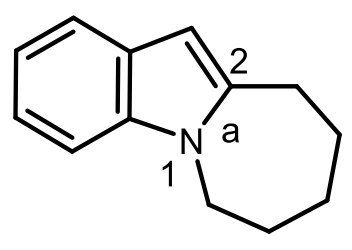

Azepino[1,2-a]indole

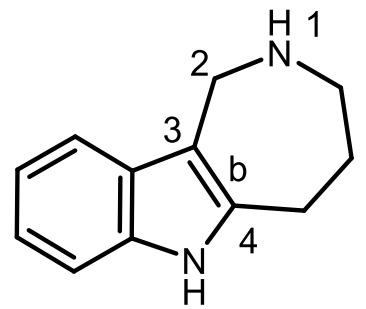

Azepino $[4,3-b]$ indole<smiles>c1ccc2c3c([nH]c2c1)N[In]CCCC3</smiles>

Azepino[2,3-b]indole

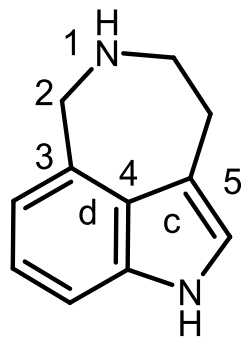

Azepino[5,4,3-cd] indole

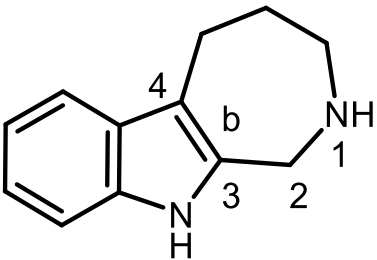

Azepino[3,4-b]indole

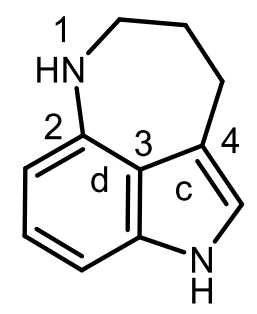

Azepino[4,3,2-cd]indole

Naturally occurring azepino[5,4,3-cd] indoles have been isolated from diverse natural sources (Figure 4). This group of alkaloids include aurantioclavine isolated from the fungus Penicillium aurantiovirens, ${ }^{27}$ clavicipitic acid from the fungus Claviceps fusiformis, ${ }^{28}$ the diastereomeric alkaloids hyrtireticuline $\mathrm{C}$ and $\mathrm{D}$ from the marine sponge Hyrtios reticulatus, ${ }^{29}$ fargesine from the roots and stems of Evodia fargesii, ${ }^{30}$ cimitrypazepine from the roots and rhizomes of black cohosh, Cimicifuga racemosa,${ }^{31}$ and bisindole alkaloid hyrtiazepine from Hyrtios erectus. ${ }^{32}$ 
Figure 4: Naturally Occurring Azepino[5,4,3-cd]indoles.<smiles>CN1CCc2c[nH]c3ccc(O)c(c23)C1</smiles>

Cimitrypazepine<smiles>CC(C)=CC1NCCc2c[nH]c3cccc1c23</smiles>

Aurantioclavine<smiles>Cc1c(O)ccc2[nH]cc(CC[N+](C)([O-])[O-])c12</smiles>

Fargesine<smiles>CC(C)=CC1N[C@@H](C(=O)O)Cc2c[nH]c3cccc1c23</smiles>

Clavicipitic acid<smiles>C[C@H]1N[C@@H](C(=O)O)Cc2c[nH]c3ccc(O)c1c23</smiles>

Hyrtioreticulins C \& D<smiles>O=C(O)[C@@H]1Cc2c[nH]c3ccc(O)c(c23)C(c2c[nH]c3ccccc23)=N1</smiles>

Hyrtiazepine

\subsection{Strategies Towards the Synthesis of Azepino[5,4,3-cd]indoles}

Among the naturally occurring indoles, azepino[5,4,3-cd]indoles have been considered attractive synthetic targets because of their biological activities and intrinsic structural complexity. A variety of synthetic strategies have been used to prepare the azepino[5,4,3-

$c d$ ] indole ring system and the most prevalent are functional group manipulations of 3,4disubstituted indoles to form the azepine ring. The formation of the carbon-nitrogen bond $\mathbf{b}$ is the most commonly used approach in total synthesis ${ }^{33,34}$ although the formation of carbon-nitrogen bond $\mathbf{c}^{35}$ and carbon-carbon bonds $\mathbf{a}^{36,37}$ and $\mathbf{d}^{38}$ have been employed (Figure 5). The assembly of both the pyrrole and azepine rings onto a functionalized benzene ring is more unusual but sequential $\mathbf{f}-\mathbf{e}-\mathbf{b},{ }^{39} \mathbf{b}$ then $\mathbf{f},{ }^{40}$ and $\mathbf{e}$ then $\mathbf{f}^{41}$ bond formations have been described. The latter methodologies offer perhaps more flexible routes to a variety of functionalized analogs compared to the use of a preassembled indole ring as the starting material. 
Figure 5: Ring Disconnections Employed in Syntheses of Naturally Occurring Azepino[5,4,3-cd]indoles

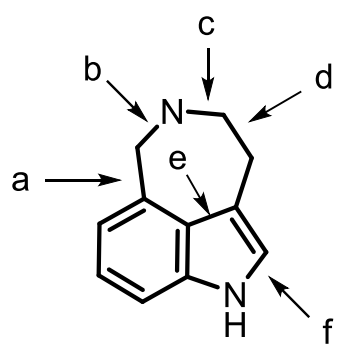

The ensuing sections will discuss various strategies used to synthesize 3,4-fused azepinoindoles.

\subsubsection{Syntheses via 'a' Bond Formation}

Cyclization at 4-position of indole via ' $a$ ' bond formation has been employed to complete the syntheses of various azepinoindoles. Bartoccini et $a l .{ }^{42}$ used rhodium(I) catalyzed intramolecular imine hydroarylation of pinacolboranate ester $\mathbf{8}$ to synthesize clavicipitic acid 12 (Scheme 4). This one pot procedure allowed the regioselective introduction of the prenyl side chain at $\mathrm{C}-4$ of tryptophan, forming a $\mathrm{C}-\mathrm{C}$ bond at the least nucleophilic position $(\mathrm{C}-4)$ of the indole core, instead of at the highly nucleophilic positions C-2 and C-3.

\section{Scheme 4: Synthesis of Clavicipitic Acid by Bartoccini et al.}<smiles>CC(=O)C(N)Cc1c[nH]c2cccc(Br)c12</smiles>

8
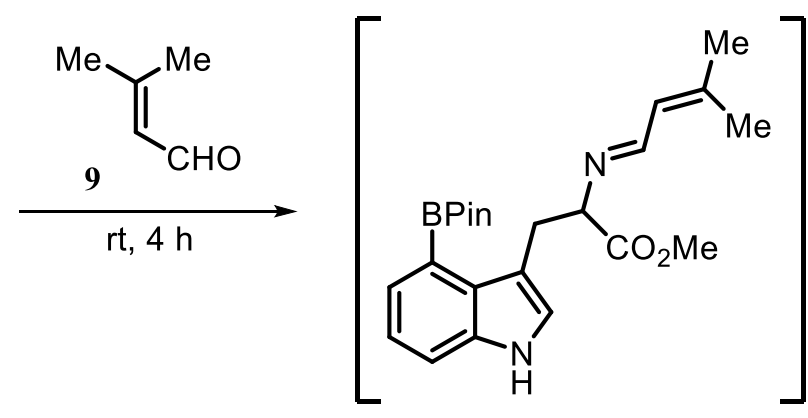

10 


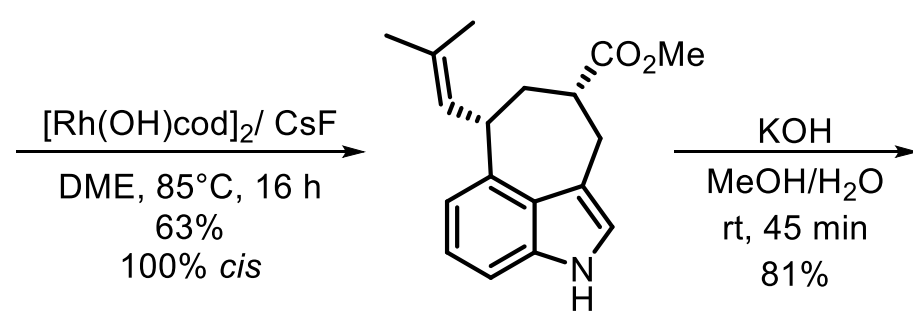

11

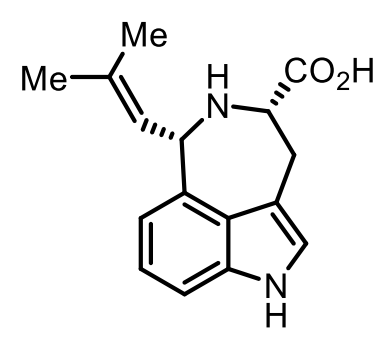

12

Use of base-promoted Pictet-Spengler reaction of in-situ formed iminium ion intermediate 15 to construct the azepine ring was pioneered by Yamada et al. The authors developed a one-pot procedure for the assembly of the azepino[5,4,3-cd] indole ring system through the reaction of $N$-benzylserotonin 13 (Scheme 5) or tryptophan with aldehydes and used this approach to provide a concise synthesis of aurantioclavine $\mathbf{1 7}$ and other hyrtios alkaloids. ${ }^{43}$

\section{Scheme 5: Syntheses Using Pictet-Spengler Reaction}

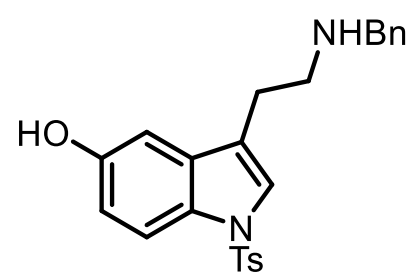

13<smiles>CC(C)=CC=O</smiles>

14

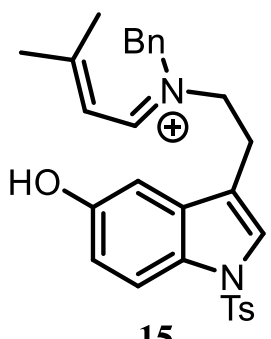

15

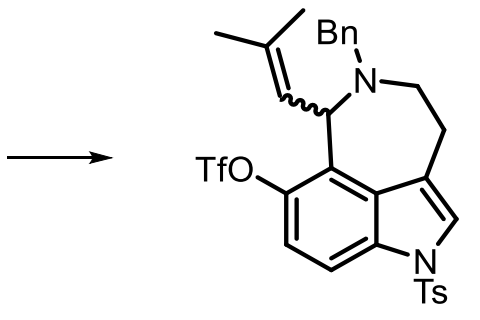

16

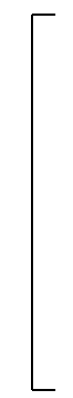<smiles>CC(C)=CC1NCCc2c[nH]c3cccc1c23</smiles>

17

\subsubsection{Syntheses via ' $b$ ' Bond Formation}

In 2009, Xu et al. ${ }^{44}$ obtained the azepinoindole via Lewis acid mediated $\mathrm{S}_{\mathrm{N}} 2$ ' reaction. It was an accidental observation that they obtained cyclized product during removal of boc group 
of 19 by magnesium perchlorate. Even though the exact mechanism has not been explored, it was postulated that $\mathrm{Mg}$ acting as Lewis acid activates the allylic - $\mathrm{OH}$ group and facilitates the $\mathrm{S}_{\mathrm{N}} 2$ ' reaction to complete the synthesis of clavicipitic acid 21 (Scheme 6).

\section{Scheme 6: Xu's Synthesis of Clavicipitic Acid}<smiles>[R6]n1cc(C[C@H](NC(C)(C)C)C(C)=O)c2c(Cl)cccc21</smiles>

18

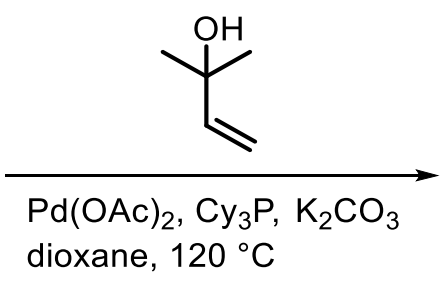

dioxane, $120^{\circ} \mathrm{C}$

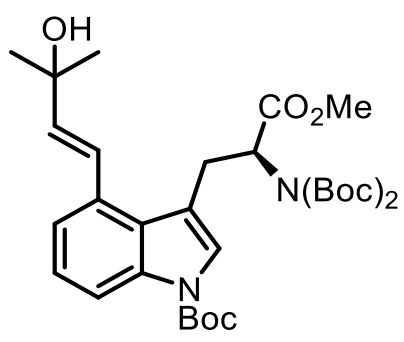

19

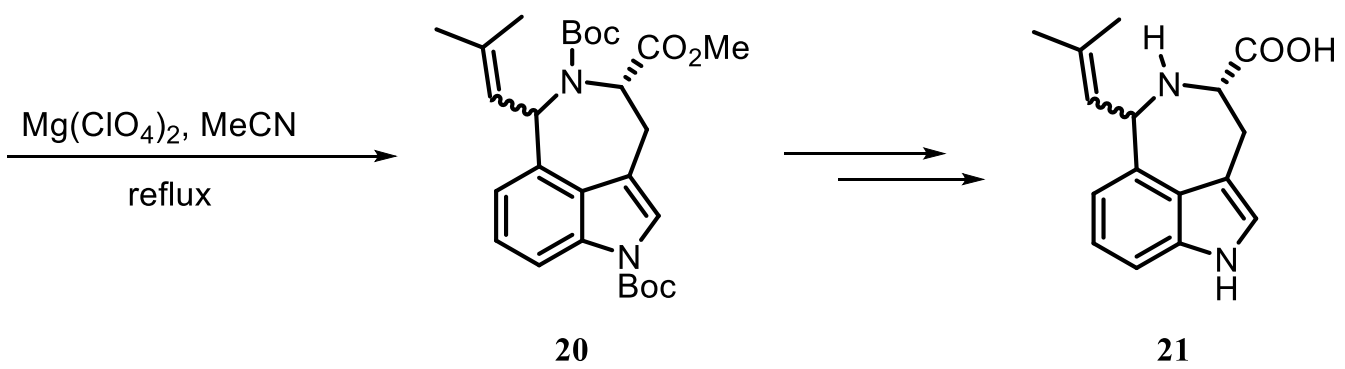

Ito et al. ${ }^{45}$ used an ortho-selective $\alpha$-hydroxyalkylation of indole $\mathbf{2 3}$ followed by intramolecular imination of resulting ketone $\mathbf{2 5}$ to assemble the azepine ring (Scheme 7) and finally complete the synthesis of hyrtiazepine 27 .

\section{Scheme 7: Synthesis of Hyrtiazepine by Ito et al.}<smiles>COc1ccc2c(c1)c(C=O)cn2[13S]</smiles>

22<smiles>Oc1ccc2c(ccn2[AsH])c1</smiles>

23<smiles></smiles> 
<smiles>O=C(O)c1c(O)ccc2c1c(CC(Nc1c[nH]c3ccc(O)cc13)C(=O)O)cn2P</smiles><smiles>[R]c1ccc2[nH]cc(C3=NCC(C(=O)O)Cc4c[nH]c5ccc(O)c3c45)c2c1</smiles><smiles>O=C(O)C1Cc2c[nH]c3ccc(O)c(c23)C(c2c[nH]c3ccc(O)cc23)=N1</smiles>

Later, a similar intramolecular reductive amination of ketone using $\mathrm{NaBH}(\mathrm{OAc})_{3}$ at room temperature was utilized to complete the synthesis of clavicipitic acid by Tahara and coworkers (Scheme 8). ${ }^{46}$

Scheme 8: Synthesis of Clavicipitic Acid by Tahara et al.<smiles>CC(=O)NC(Cc1c[nH]c2cccc(C(=O)C=C(C)C)c12)C(C)=O</smiles>

28

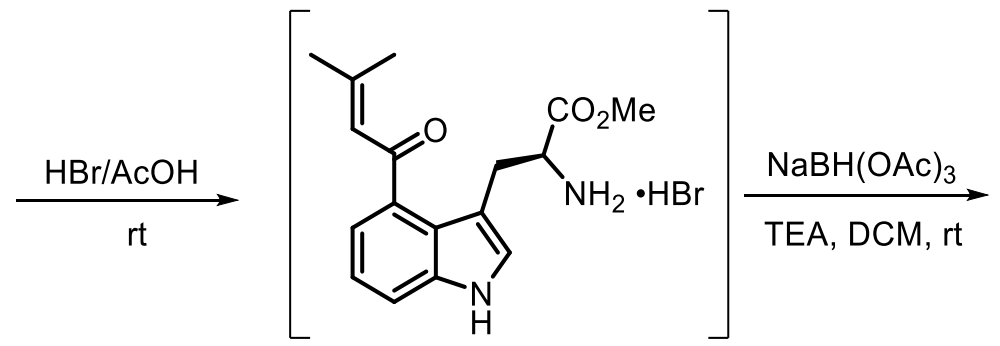

29<smiles>CC(C)=C[C@H]1c2cccc3[nH]cc(c23)C[C@H]1C(=O)O</smiles>

31 
Liu and coworkers ${ }^{47}$ performed olefination at the $\mathrm{C}_{4}$ position of tryptophan derivative $\mathbf{3 2}$ via a palladium catalyzed $\mathrm{C}-\mathrm{H}$ activation and finally a silver acetate catalyzed allylic amination to complete the synthesis of clavicipitic acid $\mathbf{3 6}$ (Scheme 9).

\section{Scheme 9: Liu's Synthesis of Clavicipitic Acid}<smiles>CC(=O)NC(Cc1cn(C(F)(F)F)c2ccccc12)C(C)=O</smiles>

32

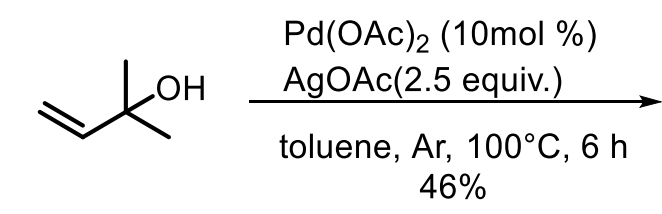

33<smiles></smiles><smiles>CC(C)=CC1N[C@@H](C(=O)O)Cc2c[nH]c3cccc1c23</smiles>

36

\subsubsection{Syntheses via 'c' Bond Formation}

Stoltz group ${ }^{48}$ in 2008 used Mitsunobu reaction of substituted indole $\mathbf{3 7}$ to assemble the azepine ring (Scheme 10) to complete the synthesis of aurantioclavine 39.

\section{Scheme 10: Synthesis of Aurantioclavine by Stoltz et al.}<smiles>CC(C)=C[C@H](N)c1cccc2c1c(CCO)cn2S</smiles>

$\stackrel{\mathrm{DIAD}, \mathrm{PPh}_{3}, \mathrm{PhMe}, 0^{\circ} \mathrm{C}}{\longrightarrow}$

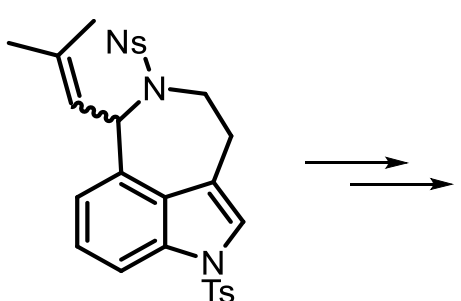

38<smiles>CC(C)=CC1NCCc2c[nH]c3cccc1c23</smiles>

39 
Similarly, Ellman et al. ${ }^{49}$ utilized the imine precursor $\mathbf{4 0}$ which underwent Grignard addition sequence to afford azepinoindole core to complete the synthesis of aurantioclavine $\mathbf{4 3}$ (Scheme 11).

Scheme 11: Synthesis of Aurantioclavine by Ellman et al.<smiles>CC(C)(C)[As](=O)/N=C/c1cccc2[nH]cc(CCO)c12</smiles>

40

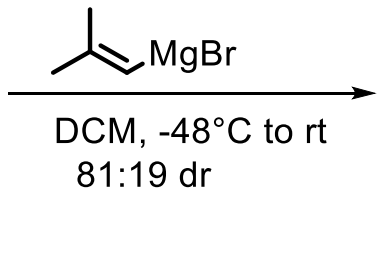

L

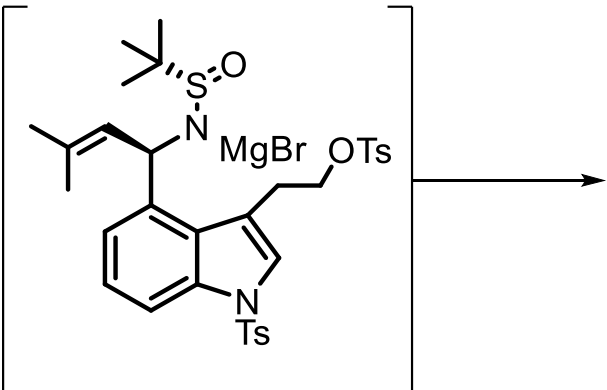

41

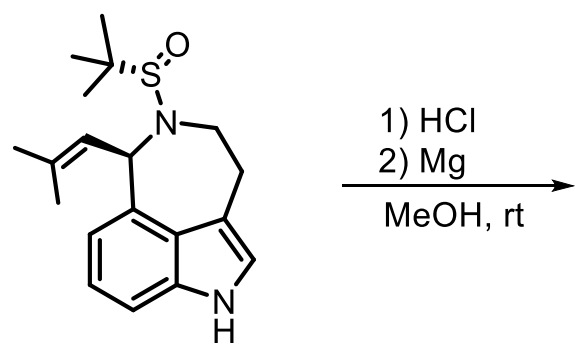

42<smiles>CC(C)=CC1NCCc2c[nH]c3cccc1c23</smiles>

43

\subsubsection{Cyclization at 3-Position of Indole}

Cheng and coworkers ${ }^{50}$ utilized chiral phosphoric acid catalyzed asymmetric PictetSpengler type reaction to close the azepine ring forming the azepinoindole. The method was used successfully to obtain many azepinoindole analogs with high enantioselectivity (Scheme 12). 

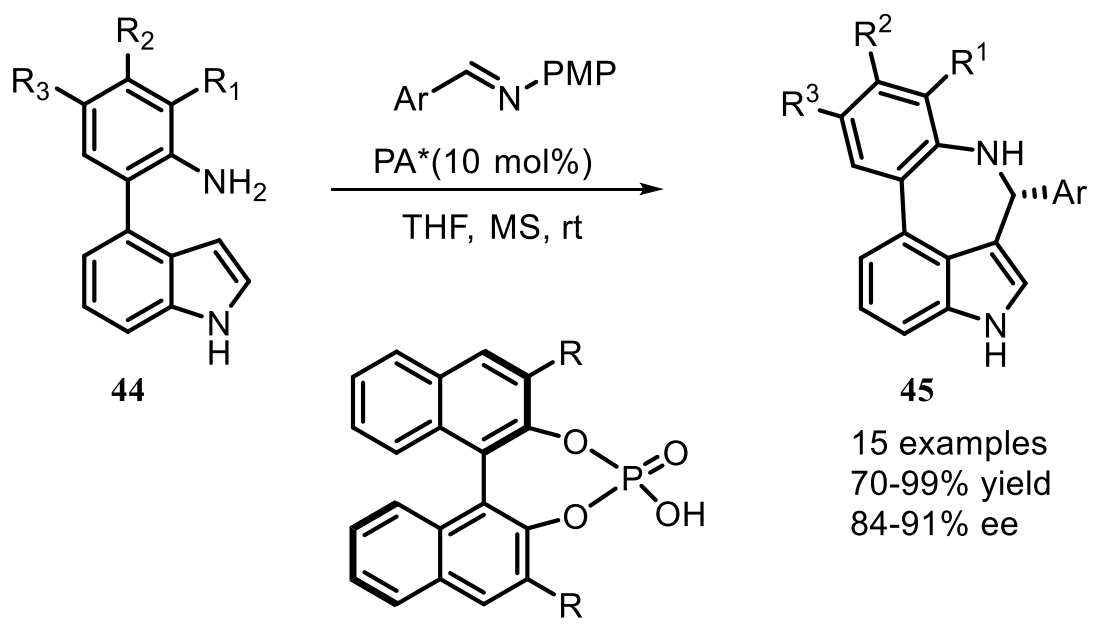

$P A^{*}, R=9$-anthracenyl

Kumar et al. ${ }^{51}$ reported the synthesis of azepinoindoles by post-Ugi indium(III)-mediated regioselective intramolecular hydroarylation reaction (Scheme 13).

\section{Scheme 13: Indium Triflate Catalyzed Cyclization}

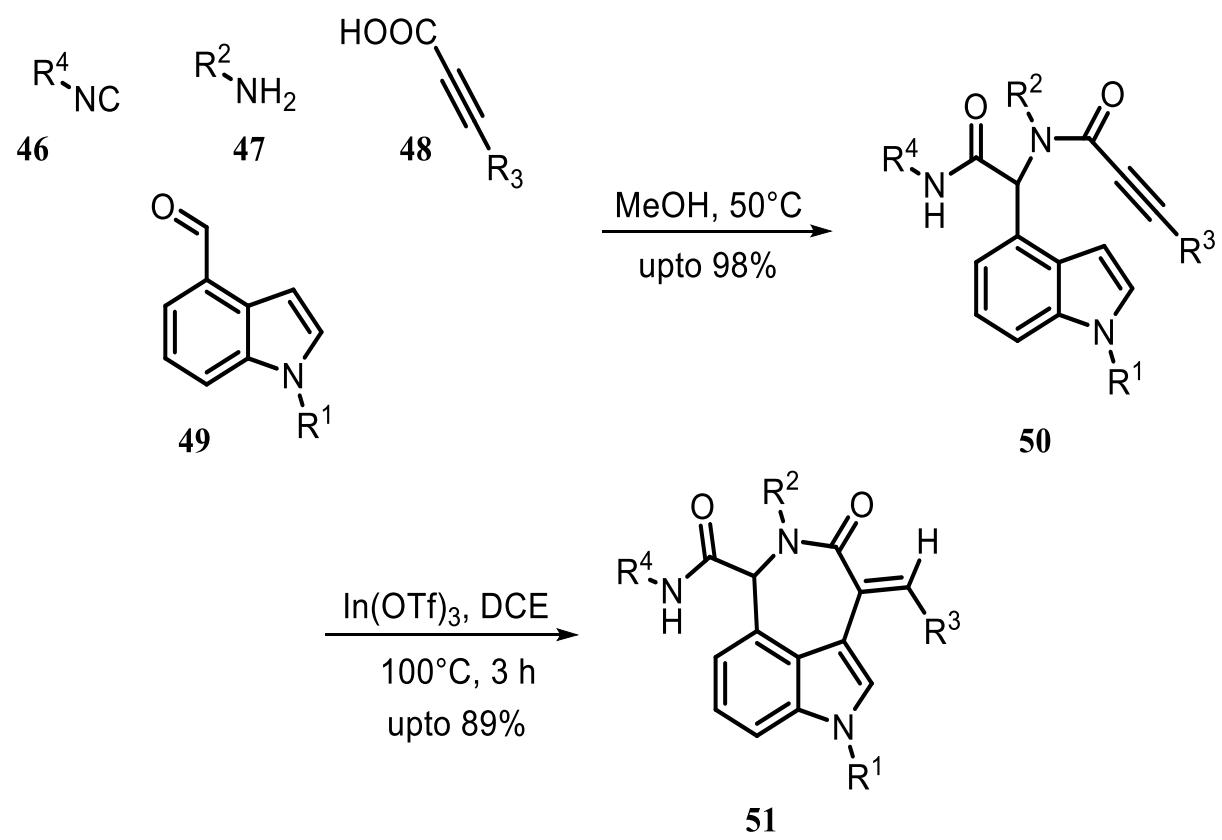


$\mathrm{Xu}$ and coworkers ${ }^{52}$ described diversity-oriented synthesis via allylic alkylation reactions where iridium catalyzed pathway provided azepinoindoles selectively (Scheme 14).

\section{Scheme 14: Iridium Catalyzed Cyclization}

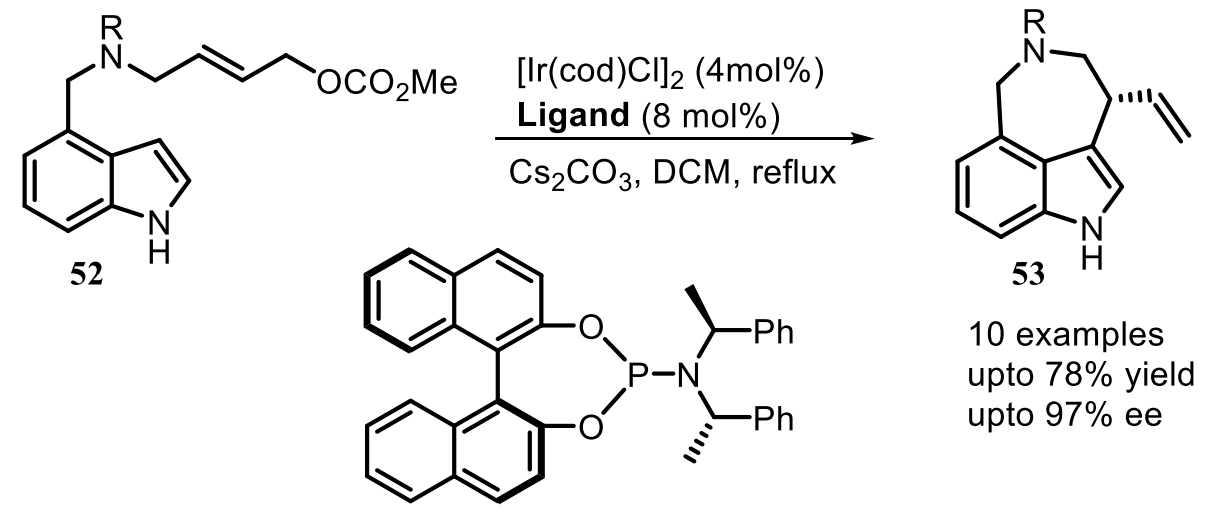

Ligand

\subsubsection{Synthesis via Sequential 'e' and 'f' or 'b', 'e' and 'f' Bond Formation}

The strategies described above, and many others utilize preassembled indole unit as the starting material. Sequential cyclizations forming the 'e' and ' $\mathrm{f}$ ' bonds or ' $\mathrm{b}$ ', 'e' and ' $\mathrm{f}$ ' bonds have also been reported. The latter methodologies employ functionalized benzene rings as the starting materials and, probably offer more flexible routes to a variety of functionalized analogs.

In 2013, Jia and coworkers ${ }^{41}$ reported intramolecular Larock indolization reaction to synthesize azepinoindole nucleus. Starting from tetrasubstituted iodoaniline $\mathbf{5 7}$ as cyclization precursor, the authors revealed a very efficient way to synthesize 3,4-fused azepinoindoles directly. The method was successfully used to complete the synthesis of fargesine $\mathbf{5 9 .}$ 


\section{Scheme 15: Intramolecular Larock Indole Synthesis}

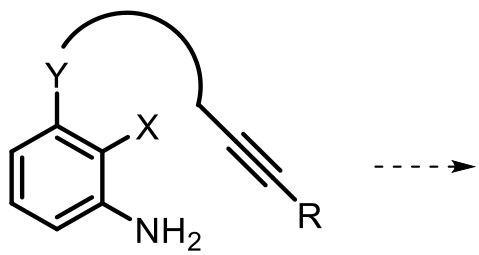

$54 \quad \mathrm{X}=\mathrm{I}, \mathrm{Br}$ $\mathrm{Y}=\mathrm{C}, \mathrm{N}, \mathrm{O}$<smiles>[R]C1=C2CCCCN([Tl])c3cccc(c32)N[Te]1</smiles>

55

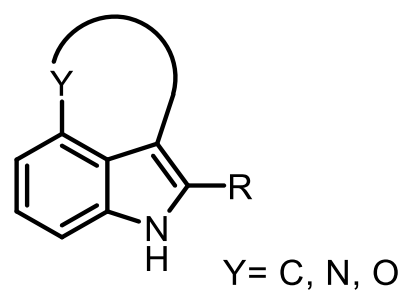

56<smiles>CC(C)(F)[I+]C#CCCNCc1c(OC(=O)OCc2ccccc2)ccc(N)c1I</smiles>

57

\section{$\mathrm{Pd}(\mathrm{OAc})_{2}, \mathrm{PPh}_{3}$ $\underset{\mathrm{K}_{2} \mathrm{CO}_{3}, \mathrm{LiCl}}{\longrightarrow}$ $99 \%$}<smiles>CC(C)(C)OC(=O)Oc1ccc2[nH]c([I-]C(=O)OC(C)(C)C)c3c2c1CN(C(=O)OC(C)(C)C)CC3</smiles>

58

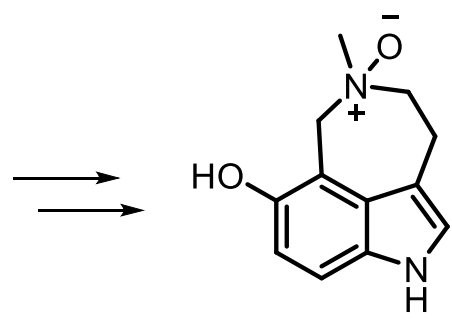

59

Söderberg et al. ${ }^{25}$ used the stepwise cyclization strategy to form the azepine ring via intramolecular Mizoroki-Heck reaction followed by $N$-heterocyclization to form the azepinoindole. The strategy was successfully used for the total synthesis of cimitrypazepine, fargesine and Hyrtioreticulins C \& D.

\section{Scheme 16: Söderberg's Sequential Cyclization}

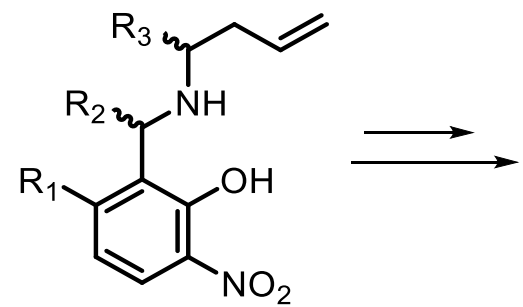

60

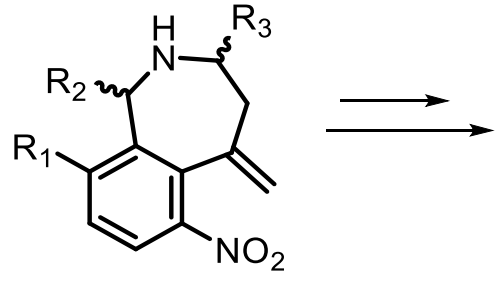

61<smiles>[R3][C]1Cc2c[nH]c3ccc([R])c(c23)C([R2])N1</smiles>

62

Recently, Nemoto et al. ${ }^{53}$ described the synthesis of 3,4-fused tricyclic indole structure based on the platinum-catalyzed intramolecular Friedel-Crafts-type $\mathrm{C}-\mathrm{H}$ coupling-allylic amination cascade and used it to complete the total synthesis of fargesine (Scheme 17). 
Compared to Jia et al. who used tetrasubstituted iodoaniline derivative, they used trisubstituted aniline derivative for the synthesis.

\section{Scheme 17: Nemoto's Synthesis of Fargesine}

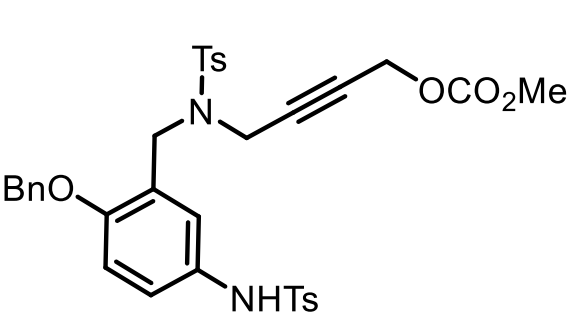

63

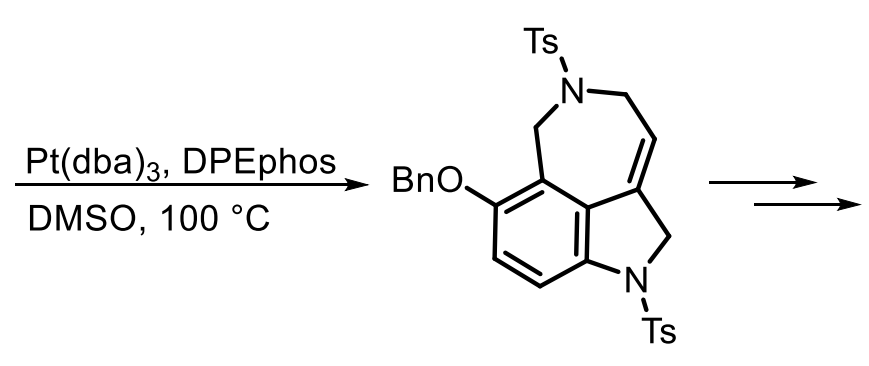

64

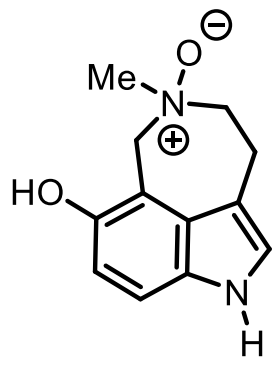

65 


\section{Chapter 2}

\section{Short Syntheses of Cimitrypazepine and Fargeisne}

2.1 Introduction to Cimitrypazepine and Fargesine 19

2.2 Literature synthesis of Cimitrypazepine and Fargesine

2.2.1 Nikolić's Synthesis of Cimitrypazepine

2.2.2 Jia’s Synthesis of Fargesine 


\subsection{Introduction to Cimitrypazepine and Fargesine}

Cimitrypazepine was extracted from the roots of black cohosh Cimicifuga racemosa in 2012. The roots/rhizomes of black cohosh have traditionally been used by Native Americans for treating a variety of medical conditions such as colds, rheumatism as well as for alleviating menopausal symptoms such as hot flashes. Because of the risks associated with hormone replacement therapy, black cohosh preparations have become popular dietary supplements among women seeking alternative treatments for menopausal complaints. Nikolić and coworkers $^{31}$ confirmed the azepinoindole structure of cimitrypazepine by comparing the mass spectrometric fragmentation of natural and synthetic samples of the alkaloid.

Traditional Chinese folk medicine has employed the fruits of Evodia fargesii as a cough suppressant as well as an analgesic for stomach aches. Three new $N$-oxide alkaloids were isolated from the roots and stems of the plant in 2006 (Figure 6). ${ }^{30}$ Among those, the tricyclic $N$ oxide alkaloid fargesine $\mathbf{6 6}$ was identified to be an azepino[5,4,3-cd]indole. Even though the components from the extracts of Evodia species have been found to be biologically active, biological activity of fargesine has not been studied so far.

Figure 6: Structure of $N$-Oxide Alkaloids from Evodia fargesii<smiles>C[N+]1([O-])CCc2c[nH]c3ccc(O)c(c23)C1</smiles>

66

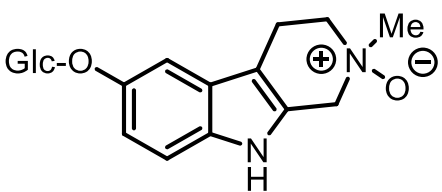

67<smiles>C[N+]([O-])([O-])CCc1c[nH]c2ccc(O)cc12</smiles>

68 


\subsection{Literature Synthesis of Cimitrypazepine and Fargesine}

\subsubsection{Nikolić's Synthesis of Cimitrypazepine}

Nikolić et al. ${ }^{31}$ reported the synthesis of cimitrypazepine 71 using a Pictet-Spengler type cyclization of $N$-methylserotonin 69 and formaldehyde as the key azepine ring-forming step. The authors reported ${ }^{1} \mathrm{H}-\mathrm{NMR}$ data and also compared the mass spectrometric data of the synthetic cimitrypazepine with the natural compound.

\section{Scheme 18: Biomimetic Synthesis of Cimitrypazepine}<smiles>CNCCc1c[nH]c2ccc(O)cc12</smiles>

69
$\stackrel{\mathrm{HCHO}, \mathrm{MeOH}, \mathrm{NEt}_{3}}{\longrightarrow}$<smiles></smiles>

70<smiles>CN1CCc2c[nH]c3ccc(O)c(c23)C1</smiles>

71

\subsubsection{Jia's Synthesis of Fargesine}

In 2013, Jia and coworkers ${ }^{41}$ developed an efficient strategy to synthesize fused tricyclic indoles from substituted 2-halogenanilines via the palladium-catalyzed intramolecular Larock indolization process and used it to complete the first total synthesis of fargesine (Scheme 19). The reductive amination between benzaldehyde and primary amine afforded the secondary amine adduct 74. Protection of both hydroxy and amine functional groups using $\mathrm{Boc}_{2} \mathrm{O}$ followed by reduction of nitro group provided the cyclization precursor $\mathbf{7 5}$ in good yield. The key Larock indolization of aniline $\mathbf{7 5}$ gave the tricyclic azepinoindole which after stepwise deprotection, $N$ methylation and $N$-oxidation sequence provided fargesine $\mathbf{7 8 .}$ 


\section{Scheme 19: Jia's Synthesis of Fargesine}<smiles>O=Cc1c(O)ccc([N+](=O)[O-])c1I</smiles>

72<smiles>NCCC#CC#[SH]</smiles>

73

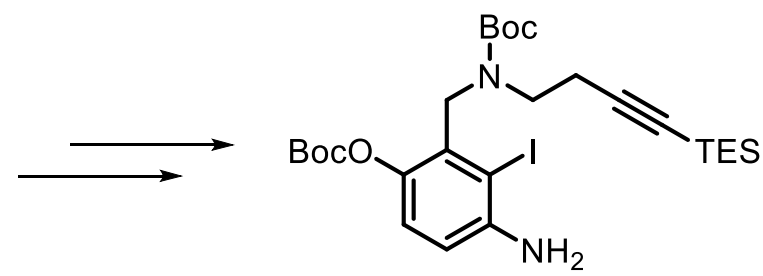

75

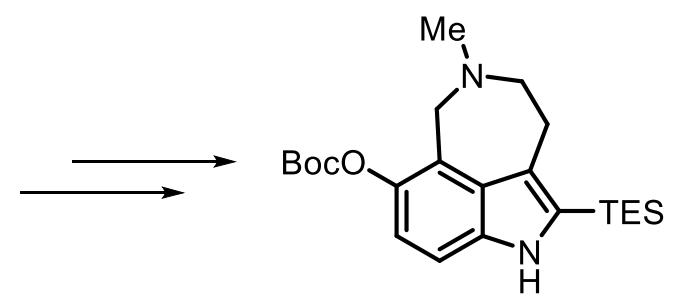

77

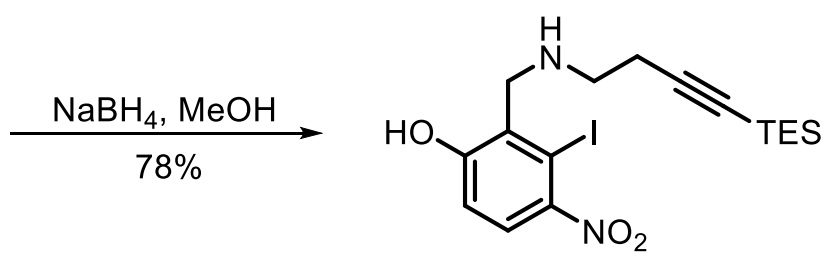

74<smiles>O=C(Oc1ccccc1)Oc1ccc2[nH]c([I-]#[SH])c3c2c1CN(C(=O)OCc1ccccc1)CC3</smiles>

76

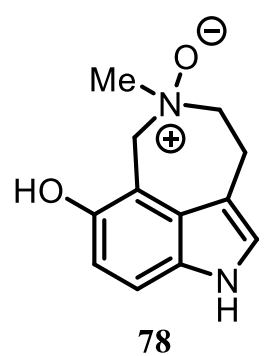

\subsubsection{Nemoto's Synthesis of Cimitrypazepine and Fargesine}

Cimitrypazepine and fargesine were also synthesized recently by Nemoto and coworkers $^{53}$ using a platinum-catalyzed intramolecular Friedel-Crafts type C-H coupling-allylic amination cascade (Scheme 20). The cyclization precursor 83 was synthesized using two consecutive Mitsunobu reactions followed by Zn-mediated reduction of nitro group. The platinum-catalyzed intramolecular Friedel-Crafts type $\mathrm{C}-\mathrm{H}$ coupling-allylic amination cascade provided the tricyclic indoline $\mathbf{8 4}$, which after TFA mediated isomerization, Na-naphthalide reduction, $N$-methylation and debenzylation sequence gave cimitrypazepine $\mathbf{8 5}$. Finally, $m$ CPBA mediated $N$-oxidation of cimitrypazepine afforded fargesine $\mathbf{8 6}$. 


\section{Scheme 20: Nemoto's Synthesis of Cimitrypazepine and Fargesine}

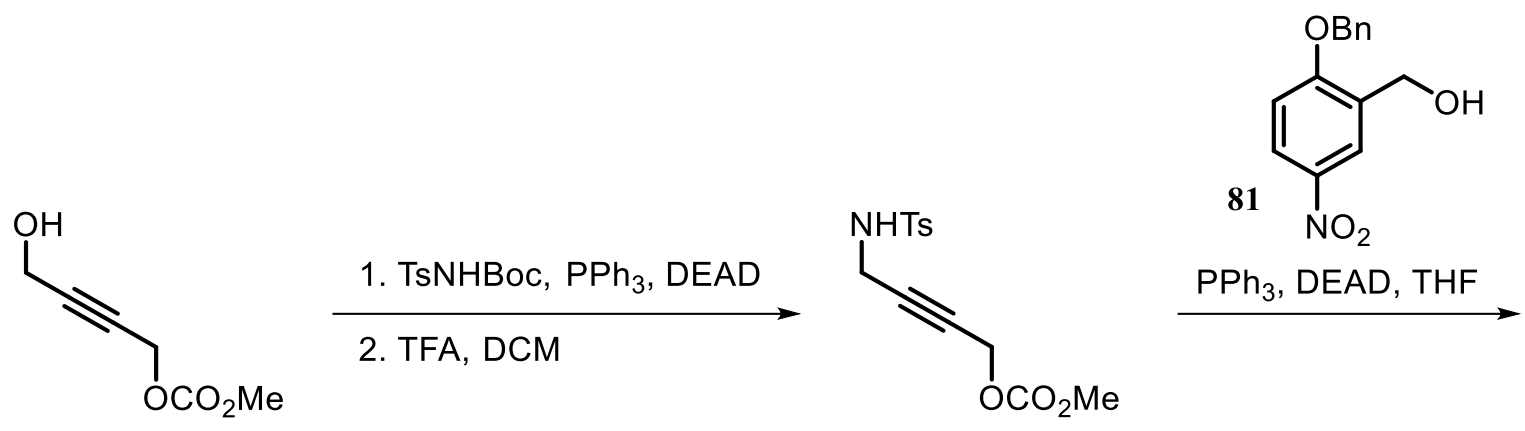

79

80<smiles>COCC#CCN([13CH3])Cc1cc([N+](=O)[O-])ccc1OCc1ccccc1</smiles>

82
1. $\mathrm{Zn}, \mathrm{AcOH}, \mathrm{DCM}$ 2.TSCl, pyridine, DCM<smiles>COCC#CCN([18F])Cc1cc(N)ccc1OCc1ccccc1</smiles>

83

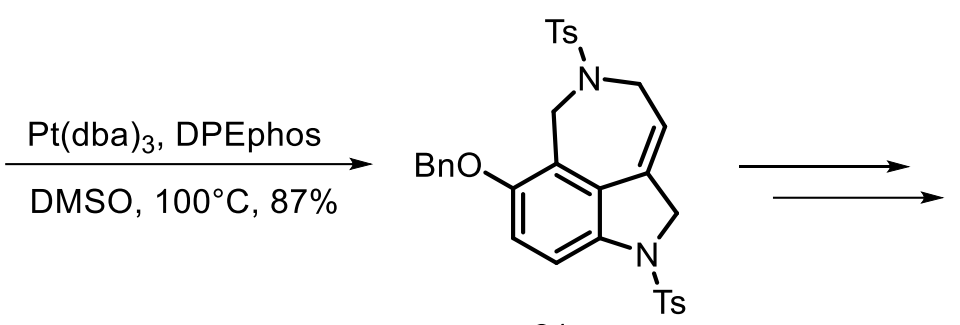

84

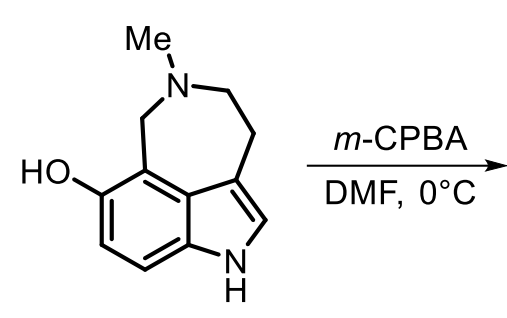

85<smiles>C[N+]1([O-])CCc2c[nH]c3ccc(O)c(c23)C1</smiles>

86

\subsection{Short Syntheses of Cimitrypazepine and Fargesine}

The unique structure of fargesine featuring an azepino $[5,4,3-c d]$ indole core and $N$-oxide function in the azepine ring inspired us to commence a synthetic study. The goal of the synthesis was to highlight the use of the Watanabe-Cenini-Söderberg palladium-catalyzed reductive $N$ heterocyclization as the key step to assemble the indole ring at the later stage of natural products synthesis. 


\subsubsection{Retrosynthetic Analysis}

The intriguing structure of cimitrypazepine and fargesine allowed us to propose a relatively concise synthetic route (Scheme 21). It was envisioned that fargesine 87 could result from $N$-oxidation of cimitrypazepine 88. Cimitrypazepine 88, in turn, could be achieved by $N$ methylation of the azepine ring of $N$-protected amine $\mathbf{8 9}$. The indole core of $\mathbf{8 9}$ could be prepared through Watanabe-Cenini-Söderberg reductive $N$-heterocyclization of nitroaromatic 90. Intramolecular Heck reaction of terminal alkene 91 would give the desired reductive $N$ heterocyclization precursor $\mathbf{9 0}$. The terminal alkene 91 could be prepared by a reductive amination of known aldehyde 93 and 4-amino-1-butene 92.

\section{Scheme 21: Proposed Retrosynthetic Outline for Cimitrypazepine and Fargesine}
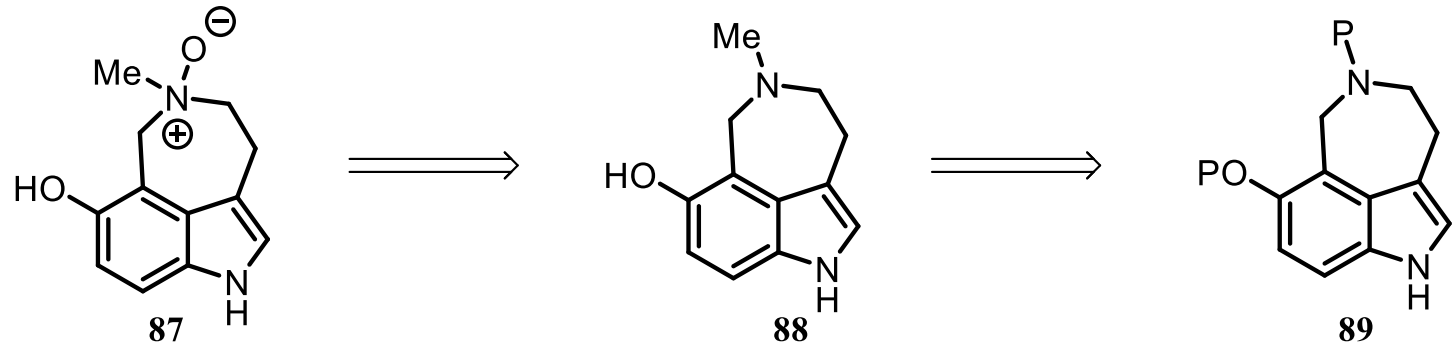

$\mathrm{P}=$ Protecting group

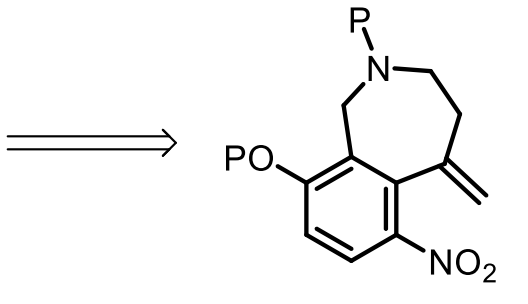

90

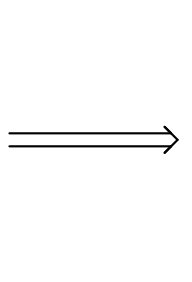<smiles>C=CCCN([PH-])Cc1c(O)ccc([N+](=O)[O-])c1I</smiles>

91<smiles>C=CCCN</smiles>

93 


\subsubsection{Results and Discussion}

6-Hydroxy-2-iodo-3-nitrobenzaldehyde $(\mathbf{9 4}),{ }^{54}$ readily prepared from commercially available 4-hydroxy-2-iodo-1-nitrobenzene, served as the starting point for the synthesis of both cimitrypazepine and fargesine (Scheme 22). Reductive amination of 94 using 4-amino-1-butene and sodium borohydride afforded the expected product 95 in good yield.

Scheme 22: Reductive Amination of 6-Hydroxy-2-iodo-3-nitrobenzaldehyde<smiles>O=Cc1c(O)ccc([N+](=O)[O-])c1I</smiles>

94

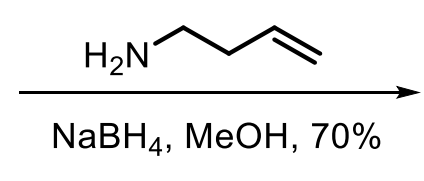

$\mathrm{NaBH}$

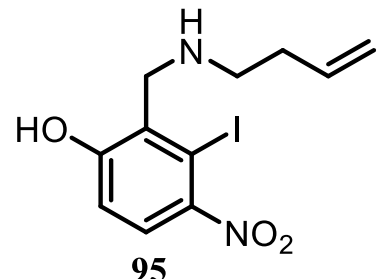

95

The next goal was to assemble the azepine ring from $\mathbf{9 5}$. Treatment of compound 95 under typical Heck conditions, using a palladium diacetate - tri( o-tolyl) phosphine catalyst system in triethylamine as the solvent and stirring at $125^{\circ} \mathrm{C}$, did not furnish any observable amount of the anticipated bicyclic product. This was probably due to the coordination of -NH and -OH group with the catalyst system inhibiting the desired coordination with the alkene moiety. Therefore, both the hydroxy and the amino group in $\mathbf{9 5}$ were protected by reaction with di-t-butyldicarbonate $\left((\mathrm{Boc})_{2} \mathrm{O}\right)$ in the presence of 4 - $(N, N$-dimethylamino)pyridine (DMAP). The starting material 95 was cleanly converted into a single new compound (by TLC). The anticipated di-protected compound 97 was the only aromatic compound seen in the ${ }^{1} \mathrm{H}$ NMR spectrum of the crude reaction mixture. However, upon purification by chromatography on silica gel, the $O$-deprotected compound $\mathbf{9 8}$ was isolated as the major product, in addition to 97 (Scheme 23). It was speculated that the $-O$-Boc group readily falls off during purification under standard silica gel chromatography conditions. However, it was possible to increase the 
percentage of di-protected compound $\mathbf{9 7}$ upon treatment of $\mathbf{9 8}$ using the same reaction conditions. The $N$-Boc group was intended to serve a dual purpose, lowering the coordination ability of the nitrogen, at times a problem in intramolecular Heck reactions, and as a source of the azepine $N$-methyl group after reduction. In our case, protection of the amine was crucial for the Heck reaction to occur. ${ }^{55}$

\section{Scheme 23: Synthesis of $O$-Boc and $N$-Boc Protected Amines 97 and 98.}

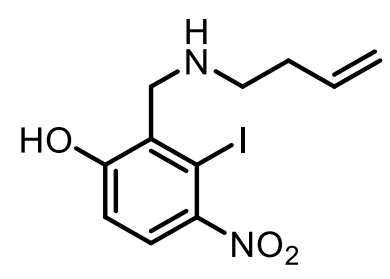

96

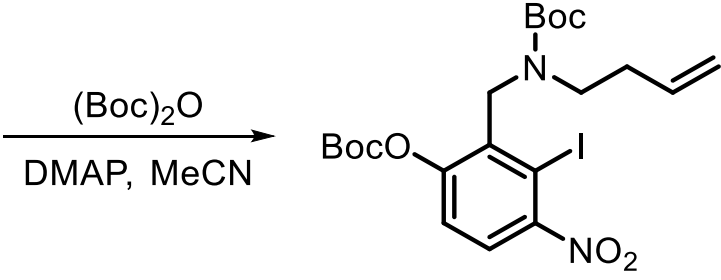

$97(31 \%)$

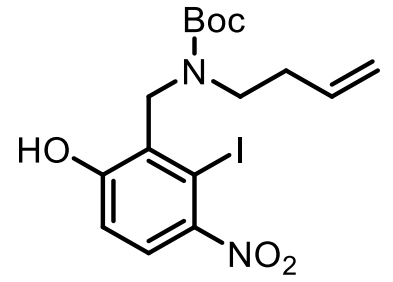

$98(56 \%)$

Intramolecular Heck reactions were attempted using both $\mathbf{9 7}$ and $\mathbf{9 8}$ in order to evaluate the need for $O$-protection. Di-protected compound 97 was completely consumed after $3.5 \mathrm{~h}$ as observed by TLC. Work up and careful purification by chromatography gave four different products (Scheme 24). Two 2-benzazepines, the di-O, $N$-Boc protected compound 101 and the $\mathrm{N}$-Boc protected compound 102, were isolated as the major products. In addition, minor amounts of two 2-benzazocines (103 and 104) differing in the position of the unsaturation in the eightmembered ring were also obtained. The latter two compounds had lost the $O$-Boc group during the reaction or upon purification of the crude reaction mixture. Intramolecular Heck reactions affording mixtures of 2-benzazepines and 2-benzazocines have previously been reported. ${ }^{56} \mathrm{It}$ should be noted that the Heck reaction of $\mathbf{9 7}$ was unpredictable and varying ratios and yields of products were obtained from seemingly identical reaction conditions and concentrations. The result shown in Scheme 24 represents the highest isolated yield of 101 and 102 obtained in 
several cyclizations of $\mathbf{9 7}$. In comparison to the reaction of $\mathbf{9 7}$, cyclization of 98 was more consistent but gave a slightly lower isolated yield of the 2-benzazepine product 102 (relative to 101+102, 66\%) and a slightly higher yield of 2-benzazocine 103 .

Scheme 24. Synthesis of 2-Benzazepines 101 and 102 and Benzazocines 103 and 104.<smiles>C=CCCN(Cc1c(OC(=O)OC(C)(C)C)ccc([N+](=O)[O-])c1I)C(=O)OCc1ccccc1</smiles>

97

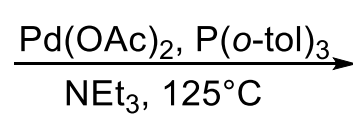<smiles>C=C1CCN(C(=O)OC(C)(C)C)Cc2c(OC(=O)OC(C)(C)C)ccc([N+](=O)[O-])c21</smiles>

$101(43 \%)$<smiles>CC(C)(C)OC(=O)N1C/C=C\Cc2c([N+](=O)[O-])ccc(O)c2C1</smiles>

103 (8\%)<smiles>C=C1CCN(C(=O)OC(C)(C)C)Cc2c(O)ccc([N+](=O)[O-])c21</smiles>

$102(58 \%)$<smiles>C=C1CCN(C(=O)OC(C)(C)C)Cc2c(O)ccc([N+](=O)[O-])c21</smiles>

$102(23 \%)$<smiles>CC(C)(C)OC(=O)N1CCC=Cc2c([N+](=O)[O-])ccc(O)c2C1</smiles>

$104(2 \%)$<smiles>CC(C)(C)OC(=O)N1C/C=C\Cc2c([N+](=O)[O-])ccc(O)c2C1</smiles>

$103(13 \%)$

Palladium catalyzed reductive $N$-heterocyclization of 101 using a

bis(dibenzylideneacetone)palladium-1,3-bis(diphenylphosphino)propane-1,10-phenanthroline catalyst system in the presence of carbon monoxide $\left(p \mathrm{CO}=6 \mathrm{~atm}, 120^{\circ} \mathrm{C}\right)$ in $N, N-$ dimethylformamide, furnished the di-N,O-protected azepino[5,4,3-cd] indole 105 in addition to 
the $N$-protected analogue 106 in 79\% total yield (Scheme 25). Treatment of compound 102 using the same reagents and reaction conditions also gave $\mathbf{1 0 6}$ in a somewhat lower isolated yield. Finally, upon treatment of $\mathbf{1 0 5}$ with sodium bis(2-methoxyethoxy) aluminum hydride (Red-Al) in toluene at reflux, the $O$-Boc group was removed and the $N$-Boc group of $\mathbf{1 0 5}$ was reduced to a methyl group affording $\mathbf{8 8}$ (cimitryptazepine). Alkaloid $\mathbf{8 8}$ was also isolated in excellent yield from Red-Al reduction of 106. All analytical data including ${ }^{1} \mathrm{H}$ and ${ }^{13} \mathrm{C} \mathrm{NMR}$, IR, HRMS, and melting point of synthetic cimitryptazepine were identical to the literature values of the compound isolated and synthesized by Nikolic et al. ${ }^{31}$

\section{Scheme 25. N-Heterocyclization and Reduction to Give Cimitryptazepine 88}<smiles>[R6]c1ccc([N+](=O)[O-])c2c1CN(C(=O)OCc1ccccc1)CCC2=O</smiles>

$101(\mathrm{R}=\mathrm{Boc})$ $102(\mathrm{R}=\mathrm{H})$

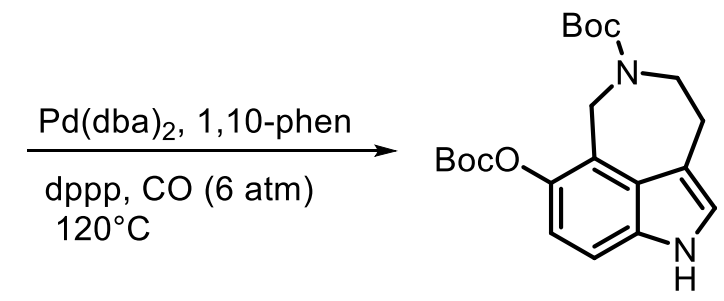

$105(50 \%)$<smiles>CN1CCc2c[nH]c3ccc(O)c(c23)C1</smiles>

88 (from 105, 74\%)

$\mathbf{8 8}$ (from 106, 95\%)

Direct oxidation of the azepine-nitrogen of $\mathbf{8 8}$ using $m$-chloroperbenzoic acid ( $m$-CPBA) in dichloromethane ${ }^{57}$ or hydrogen peroxide - ammonium hydrogen carbonate in water did not furnish fargesine; instead intractable mixtures were obtained in all attempted reactions. In place of a direct oxidation of $\mathbf{8 8}$ to fargesine, we decided to intercept an intermediate reported in the 
previous synthesis of fargesine. ${ }^{41}$ Thus, cimitrypazepine $\mathbf{8 8}$ was $O$-Boc-protected to give $\mathbf{1 0 7}$ in excellent yield. This compound has previously been oxidized and deprotected using $m$-CPBA and sodium hydroxide, respectively, to afford fargesine $\mathbf{8 7}$.

Scheme 26. Synthesis of Fargesine 87<smiles>CN1CCc2c[nH]c3ccc(O)c(c23)C1</smiles><smiles>C[N+]([O-])([O-])CCc1c[nH]c2ccc(O)c(CCN)c12</smiles>

87 (Not observed)<smiles>C[N+](C)=NCOC(C)(C)C</smiles>

88

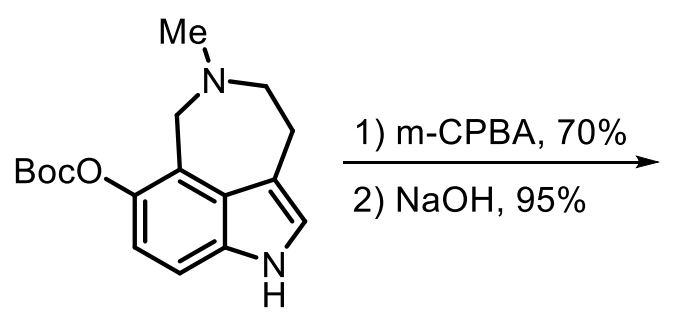

$107(84 \%)$<smiles></smiles>

87

\subsection{Conclusions}

A concise linear total syntheses of the naturally occurring azepino[5,4,3-cd]indoles, cimitrypazepine and fargesine has been completed utilizing an intramolecular Heck reaction forming the azepine ring and Watanabe-Cenini- Söderberg reductive $N$-heterocyclization building the pyrrole ring of the indole as key steps. The flexibility offered by our intramolecular Heck reaction to form the azepine ring and late stage reductive $N$-heterocyclization opens the possibility of using the strategy in other synthesis of other azepinoindole alkaloids. 


\section{Chapter 3}

\section{Syntheses of Hyrtioreticulins C \& D}

3.1 Introduction to Hyrtioreticulins C \& D 30

3.2 Previous Syntheses of Hyrtioreticulins C \& D 31

3.2.1 Abe and Yamada Syntheses of Hyrtioreticulins C \& D 31

3.3 Total Syntheses of Hyrtioreticulins C \& D 31

3.3.1 Retrosynthetic Analysis $\quad 32$

3.3.2 Results and Discussion 33

$\begin{array}{ll}\text { 3.3.3 Conclusions } & 41\end{array}$ 


\subsection{Introduction to Hyrtioreticulins C \& D}

Marine sponges of the genus Hyrtios are known to be rich sources of structurally diverse natural products such as alkaloids, sesterterpenes and macrolide with significant cytotoxic and antimicrobial activities. Out of six hyrtioreticuline analogs (A-F, 108-113) isolated so far from the Hyrtios species (Figure 7), ${ }^{58,59}$ Hyrtioreticulins A and B inhibited ubiquitin-activating enzyme (E1). Hyrtioreticulins C \& D were isolated as diastereomeric azepinoindole alkaloids from the marine sponge Hyrtios reticulatus, which was collected in Indonesia by Tsukamoto and co-workers. ${ }^{58}$ Even though the detailed biological study of hyrtioreticulins C \& D has not been reported, these azepinoindole alkaloids are attractive synthetic targets as they resemble aurantioclavine and clavicipitic acid. The first synthesis of hyrtioreticulins C and D was reported by Abe and Yamada ${ }^{43 c}$ in 2017 wherein a Pictet-Spengler cyclization was employed as the key step.

Figure 7: Hyrtioreticulins A-F (108-113) Isolated From Hyrtios reticulatus<smiles>O=C(O)C1Cc2c([nH]c3ccc(O)cc23)[C@H](Cc2c[nH]cn2)N1</smiles>

108<smiles>O=C(O)C1Cc2c([nH]c3ccc(O)cc23)[C@H](Cc2c[nH]cn2)N1</smiles>

109<smiles>C[C@H]1NC(=O)Cc2c[nH]c3ccc(O)c1c23</smiles>

110<smiles>C[C@H]1NC(C(=O)O)Cc2c[nH]c3ccc(O)c1c23</smiles>

111<smiles>C[C@H]1NC(C(=O)O)Cc2c1[nH]c1ccc(O)cc21</smiles>

112<smiles>C[C@@H]1N[C@@H](C(=O)O)Cc2c1[nH]c1ccc(O)c([C@H](C)NCC(=O)O)c21</smiles>

113 


\subsection{Previous Synthesis of Hyrtioreticulins C \& D}

\subsubsection{Abe and Yamada Synthesis}

In 2017, Abe and Yamada ${ }^{43 c}$ reported the first total syntheses of hyrtioreticulins C \& D. Their biomimetic synthesis featured an unprecedented base-promoted C-4 Pictet-Spengler reaction of tryptophan. Microwave irradiation of 5-hydroxytryptophan 114 with 3 equivalents of acetaldehyde under basic condition selectively formed azepino[5,4,3-cd]indoles having trans isomer as the major product (Scheme 27). Basic hydrolysis of azepinoindoles 115 and 116 gave hyrtioreticulins C \& D (117 and 118), respectively.

\section{Scheme 27: First Synthesis of Hyrtioreticulins C \& D}<smiles>CC(=O)CC(N)Cc1c[nH]c2ccc(O)cc12</smiles>

114

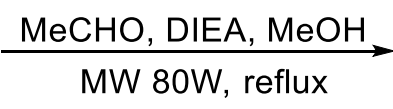

$\underset{\mathrm{MeOH}}{\stackrel{10 \% \mathrm{NaOH} / \mathrm{H}_{2} \mathrm{O}}{\longrightarrow}}$

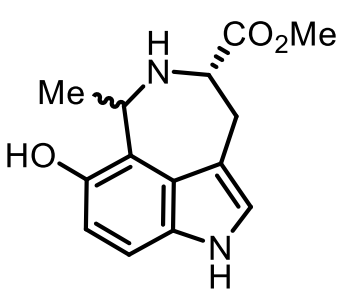

$115(\beta-\mathrm{Me}), 59 \%$

$116(\alpha-\mathrm{Me}), 4 \%$

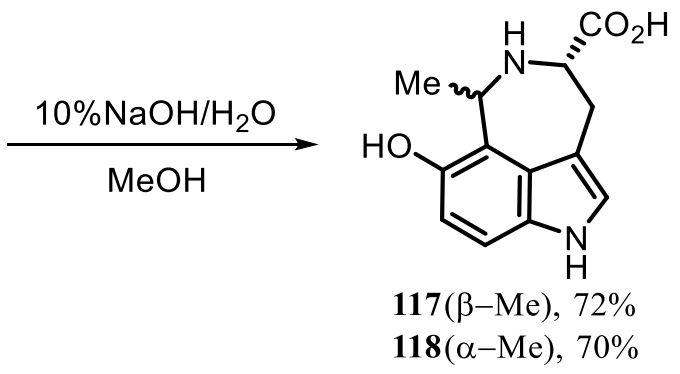

\subsection{Total Syntheses of Hyrtioreticulins C \& D}

Abe and Yamada synthesis utilized the preformed tryptophan which possessed a preinstalled indole ring as the starting material. Our goal was to elaborate the use of Watanabe- 
Cenini-Söderberg reductive $N$-heterocyclization reaction as an efficient tool for a late stage indole ring formation.

\subsubsection{Retrosynthetic Analysis}

The resemblance of hyrtioreticulins with cimitrypazepine and fargesine previously synthesized in our lab ${ }^{25}$ prompted us to propose a relatively similar synthetic route (Scheme 28). In order to explore the versatility of our terminally unsaturated $N$-tethered cyclization precursor, our initial synthetic design was inspired from the work of Zhang et al. that utilized an efficient rhodium(III)-catalyzed intramolecular hydroarylation of alkynes. ${ }^{60}$ The method would serve as an alternative route for installing the key azepine ring and thereby provide a straight forward route, after reductive $N$ - heterocyclization, to the tricyclic azepinoindole.

It was envisioned that the hyrtioreticulins 119 could result from protecting group manipulation of 120. The indole core of $\mathbf{1 2 0}$ could be prepared through Watanabe-Cenini-Söderberg reductive $N$ heterocyclization of nitroaromatic 121. It was speculated that the rhodium(III)-catalyzed intramolecular hydroarylation of alkynes proposed by Zhang and coworkers could be used for terminal alkyne $\mathbf{1 2 2}$ to give the desired reductive cyclization precursor 121. The terminal alkyne 122 could be prepared by reductive amination of known acetophenone derivative 124 and propargyl glycine methyl ester $\mathbf{1 2 3}$.

\section{Scheme 28: Proposed Retrosynthetic Outline for Hyrtioreticulins}

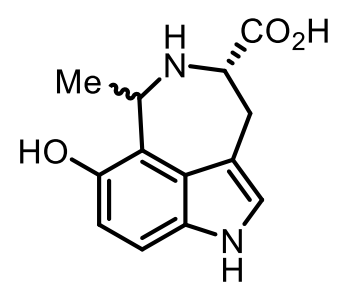

119

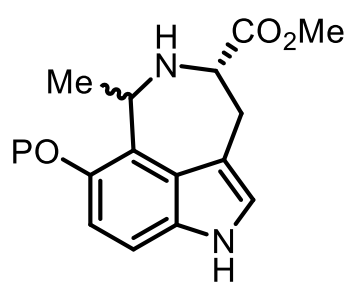

120<smiles>[CH]C1N[C@H](C(C)=O)CC(=C)c2c([N+](=O)[O-])ccc(O)c21</smiles>

121 


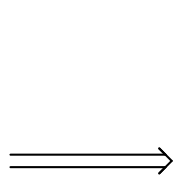

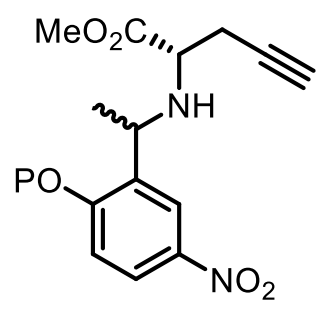

122

$\mathrm{P}=$ Protecting group

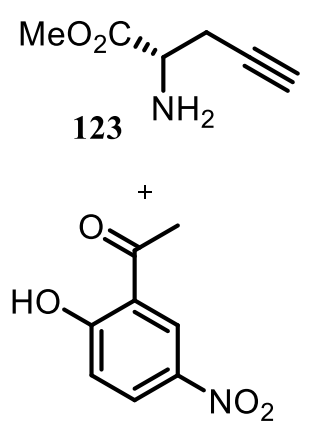

124

\subsubsection{Results and Discussion}

The forward synthesis of hyrtioreticulins started from commercially available 2-hydroxy-5nitroacetophenone. Under the optimized conditions, transimination of in situ generated primary ketimine of 2-hydroxy-5-nitroacetophenone 125 with amine 126 followed by sodium borohydride reduction of the corresponding imine gave the new racemic amine 127 in 33\% overall yield (Scheme 29).

Scheme 29: Indirect Reductive Amination to Form 127

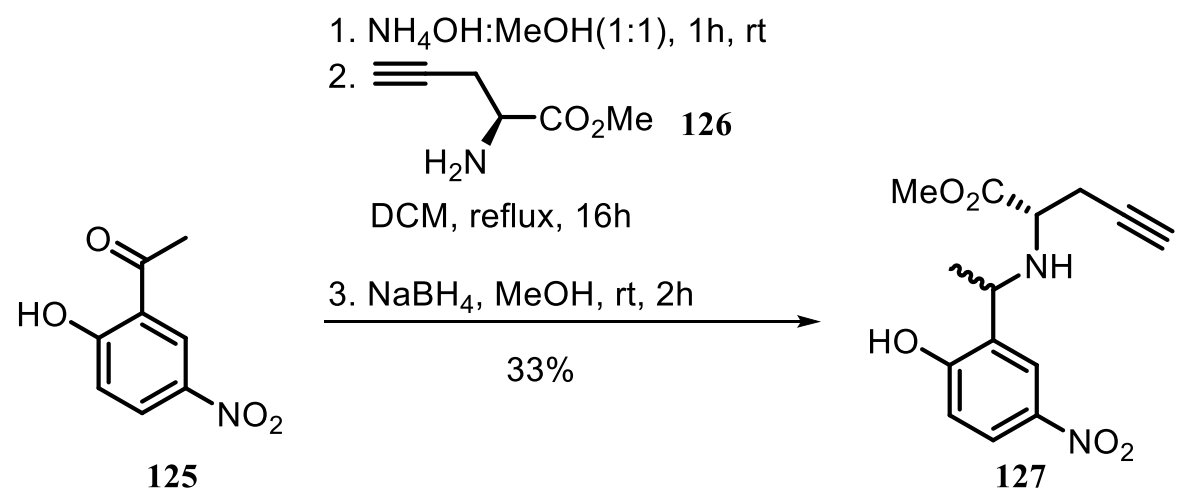

Amine $\mathbf{1 2 7}$ was then subjected to $\mathrm{Rh}(\mathrm{III})$-catalyzed intramolecular annulation as described by Zhang et al. ${ }^{60}$ Unfortunately, the desired 2-benzazepine 129 was not detected even after varied reaction conditions; instead an undesired cyclization product $\mathbf{1 2 8}$ was isolated as the sole product in $42 \%$ yield (Scheme 30 ). The product 128 was also isolated in about $30 \%$ yield 
under similar reaction conditions without the rhodium catalyst. The isolated product probably resulted from an intramolecular hydroamination of terminal alkyne 127 favoring a 5-endo-dig cyclization. ${ }^{61}$ It was also expected that the unprotected secondary amine in $\mathbf{1 2 7}$ could coordinate with the metal and prevent the otherwise possible $\mathrm{C}-\mathrm{H}$ activation by the catalyst thereby favoring the formation of $\mathbf{1 2 8}$.

\section{Scheme 30: Undesired Cyclization of 127}

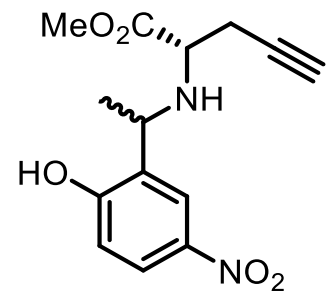

127

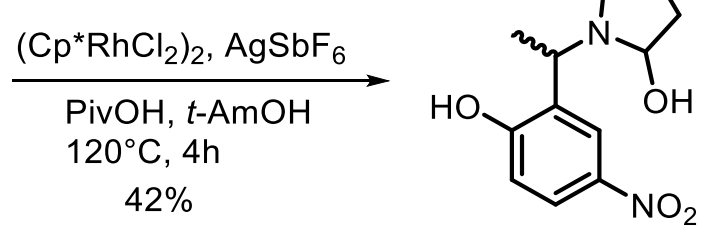

128

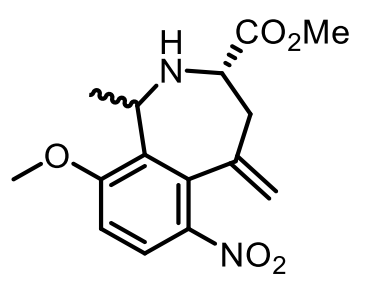

129

not observed

These results prompted us to revisit our synthetic design where the key benzazepine could be obtained using Mizoroki-Heck reaction of terminal alkene as evidenced by our synthesis of cimitrypazepine and fargesine. ${ }^{25}$ This allowed us to modify our retrosynthetic analysis as shown in scheme 31 . It was envisioned that the hyrtioreticulins $\mathbf{1 3 0}$ could result, after the removal of protecting groups, from Watanabe-Cenini-Söderberg reductive $N$ heterocyclization of benzazepine 131. Intramolecular Mizoroki-Heck reaction of terminal alkene 132 would give the desired reductive $N$-heterocyclization precursor 131 . The terminal alkene 132 could be prepared by reductive amination of known acetophenone derivative 133 and allyl glycine methyl ester 134. 


\section{Scheme 31: Revised Retrosynthetic Outline for Hyrtioreticulins}<smiles>C[C@H]1N[C@@H](C(=O)O)Cc2c[nH]c3ccc(O)c1c23</smiles>

130

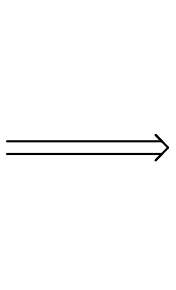

133<smiles>C=C1C[C@H](C(C)=O)N[C@H](C)c2c(OC)ccc([N+](=O)[O-])c21</smiles>

131<smiles>C=CC[C@H](N[C@@H](C)C(C)=O)c1c(OC)ccc([N+](=O)[O-])c1[O-]</smiles>

132<smiles>C=CC=C</smiles>

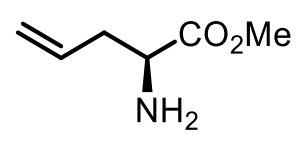

134

The alternative synthesis was started from nitration of commercially available 2-hydroxy6-methoxyacetophenone $\mathbf{1 3 5}$ according to Cushman et al. ${ }^{62}$ The authors reported only $\mathbf{1 3 8}$ as the nitration product from 135. But after careful purification of the crude reaction mixture by chromatography, we were able to isolate three products 136, 137 and $\mathbf{1 3 7}$ (Scheme 32).

\section{Scheme 32: Nitration of 2-Hydroxy-6-methoxyacetophenone}<smiles>COc1cccc(O)c1C(C)=O</smiles>

135<smiles></smiles><smiles>COc1c([N+](=O)[O-])ccc(O)c1C(C)=O</smiles>

$136(6 \%)$<smiles>COc1c([N+](=O)[O-])cc([N+](=O)[O-])c(O)c1C(C)=O</smiles>

$137(7 \%)$<smiles>COc1ccc([N+](=O)[O-])c(O)c1C(C)=O</smiles>

$138(32 \%)$

The next goal was to use the desired $\mathbf{1 3 8}$ to construct the Heck reaction precursor. It should be noted here that direct reductive amination of $\mathbf{1 3 8}$ with allyl glycine methyl ester $\mathbf{1 3 4}$ using a series of reagents $\left(\mathrm{NaBH}_{4}, \mathrm{NaBH}_{3} \mathrm{CN}, \mathrm{TiCl}_{4}\right.$ etc. $)$ did not produce the desired product. The ketone 138 was then subjected to trans-imination conditions by treating it with excess 
ammonia solution in methanol followed by the amino acid methyl ester before reducing the corresponding imine with sodium borohydride. The product obtained was a racemic mixture $\mathbf{1 4 0}$ in $78 \%$ overall yield (Scheme 33 ).

\section{Scheme 33: Trans-imination of 2-Hydroxy-6-methoxy-3-nitroacetophenone with L-}

\section{allylglycine Methyl Ester}

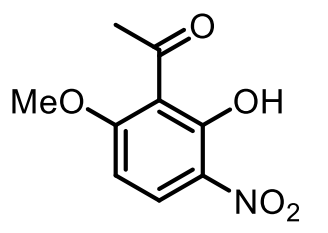

138

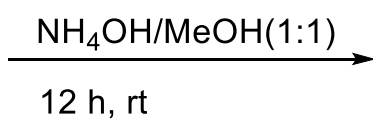

$12 \mathrm{~h}, \mathrm{rt}$

2) $\mathrm{NaBH}_{4}, \mathrm{MeOH}$
1)

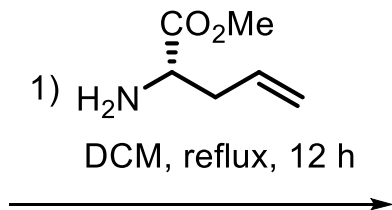<smiles>COc1ccc([N+](=O)[O-])c(O)c1C(C)=N</smiles>

139

not isolated

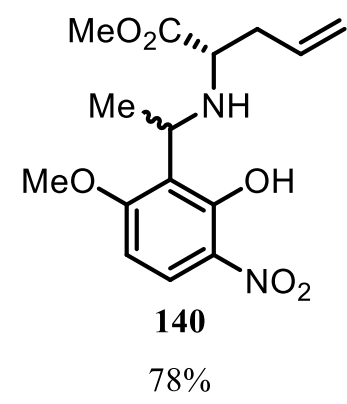

Intramolecular Heck reaction of $\mathbf{1 4 0}$ using one of the standard catalyst systems, palladium diacetate - tri $(o$-tolyl $)$ phosphine - triethyl amine $\left(125^{\circ} \mathrm{C}\right)^{25,55}$ did not furnish any observable amount of the anticipated bicyclic product. Eventually, we decided to adopt an alternative method recently reported by Zhou et al. ${ }^{63}$ The authors described a highly regioselective intermolecular Mizoroki-Heck reaction of aryltriflates with aliphatic olefins leading to the formation of 1,1-disubstituted alkene. To the best of our knowledge, the catalyst system developed by Zhou et al. has not been evaluated in intramolecular reactions.

Even though partial separation of the diastereomers of $\mathbf{1 4 0}$ was possible, they were directly reacted with trifluoromethanesulfonic anhydride $\left(\mathrm{Tf}_{2} \mathrm{O}\right)$ and pyridine with the 
speculation that the corresponding triflates could be separated during purification of the crude product. As expected, the corresponding triflates 142 and 143 were readily separated during purification of the crude reaction mixture with excellent isolated yields (Scheme 34).

\section{Scheme 34: Triflation of Racemic Phenol 140}<smiles>C=CC[C@H](COC)N[C@H](C(C)=O)c1c(OC)ccc([N+](=O)[O-])c1O</smiles>

140

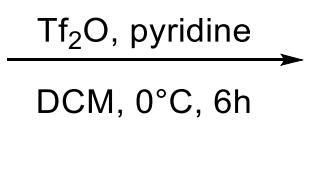

$142(\beta-\mathrm{Me} 53 \%)$

$143(\alpha-M e 36 \%)$

When the triflates 142 and 143 were subjected to intramolecular Mizoroki-Heck reaction under Zhou's conditions using bis(dibenzylidenacetone)palladium $\left(\mathrm{Pd}(\mathrm{dba})_{2}\right)$, bis(diphenylphosphino)ferroccene (dppf), and urotropin in $N, N$-dimethylacetamide (DMA), the corresponding 2-benzazepines $\mathbf{1 4 4}$ and $\mathbf{1 4 5}$ were isolated as the only products albeit in moderate yields (Scheme 35). It should be noted here that cyclization of $\mathbf{1 4 2}$ gave a slightly higher isolated yield than 143 .

\section{Scheme 35: Synthesis of 2-Benzazepines 144 and 145.}<smiles>C=CC[C@@H](N[C@H](C)c1c(OC)ccc([N+](=O)[O-])c1OC)C(C)=O</smiles>

$142(\beta-\mathrm{Me})$

$143(\alpha-\mathrm{Me})$

$$
\underset{\mathrm{Pd}(\mathrm{dba})_{2}, \mathrm{dppf} \text {, urotropine, DMA }}{85^{\circ} \mathrm{C}, 40 \mathrm{~h}}
$$

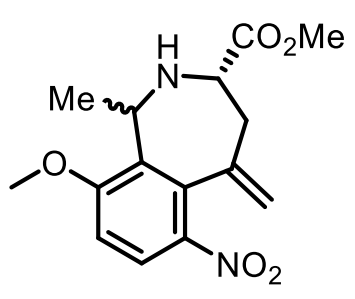

$144(53 \%)$

$145(43 \%)$

Watanabe-Cenini-Söderberg reductive $N$-heterocyclization of 144 and 145 using a 
bis(dibenzylideneacetone)palladium-1,3-bis(diphenyl)phosphinopropane- 1,10-phenanthroline catalyst system in the presence of carbon monoxide $\left(p \mathrm{CO}=6 \mathrm{~atm}, 120^{\circ} \mathrm{C}\right)$ in $\mathrm{N}, \mathrm{N}$ -

dimethylformamide, furnished the azepino[5,4,3-cd] indoles 146 and 147 in $44 \%$ and $43 \%$ yield (Scheme 36), respectively.

Scheme 36: $N$-heterocyclization to Give Azepinoindoles 146 and 147.

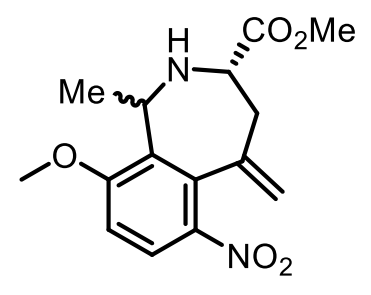

$144(\beta-\mathrm{Me})$ $145(\alpha-\mathrm{Me})$

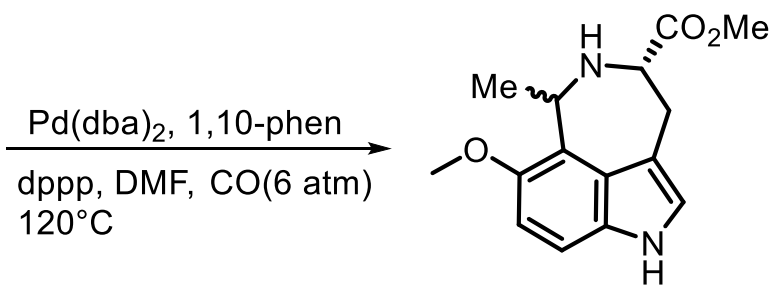
$120^{\circ} \mathrm{C}$

$146(44 \%)$

$147(43 \%)$

Finally, removal of the protecting groups in 146 and 147 would give hyrtioreticulins C \& D. Demethylation using $\mathrm{BBr}_{3}$ in $\mathrm{DCM}$ has been reported to be successful in similar substrates in the total synthesis of hyrtiazepine by Ito et al. ${ }^{45}$ Treatment of 146 and 147 with $\mathrm{BBr}_{3}$ under reported and varied temperature and solvent conditions did not furnish hyrtioreticulins; instead intractable mixtures were obtained in all attempted reactions. This prompted us to think about alternative protecting groups to replace the methoxy group. We anticipated that benzyl protecting group would be a better choice as it could be easily removed by reduction over $\mathrm{Pd} / \mathrm{C} .{ }^{43 \mathrm{~d}, 45}$

Thus, the synthesis was attempted again starting from nitration of 2-hydroxy-6benzylacetophenone according to Cushman et al. ${ }^{62}$ which gave two products 149 and 150 in $4 \%$ and $45 \%$ yield respectively (Scheme 37 ). 


\section{Scheme 37: Nitration of 2-Hydroxy-6-benzylacetophenone}<smiles>CCOc1cccc(O)c1C(C)=O</smiles>

148

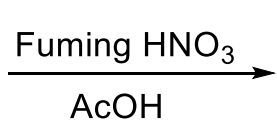

$149(4 \%)$<smiles>CCOc1ccc([N+](=O)[O-])c(O)c1C(C)=O</smiles>

$150(45 \%)$

Imination trans-imination of the desired $\mathbf{1 5 0}$ with allylgycine methyl ester under the same conditions described above afforded the cis and trans products $\mathbf{1 5 3}$ and $\mathbf{1 5 2}$ which were readily separated by chromatography with $34 \%$ and $45 \%$ yields respectively. Treatment of 152 and 153 with triflic anhydride in presence of pyridine afforded the corresponding triflates 145 and 155 in excellent yields (Scheme 38).

Scheme 38: Imination, Trans-imination and Triflation to Give 154 and 155

1. $\mathrm{NH}_{4} \mathrm{OH}: \mathrm{MeOH}(1: 1), \mathrm{rt}, 12 \mathrm{~h}$<smiles>CC(=O)c1c(OCc2ccccc2)ccc([N+](=O)[O-])c1O</smiles>

151

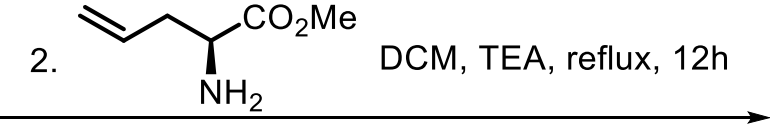

3. $\mathrm{NaBH}_{4}, \mathrm{MeOH}, \mathrm{rt}, 1 \mathrm{~h}$<smiles>C=CC[C@H](COC)N[C@@H](C(C)=O)c1c(OCc2ccccc2)ccc([N+](=O)[O-])c1O</smiles>

$152(\beta-\mathrm{Me} 45 \%)$

$153(\alpha-\mathrm{Me} 34 \%)$

$\mathrm{Tf}_{2} \mathrm{O}$, pyridine, $\mathrm{DCM}, 0^{\circ} \mathrm{C}, 4 \mathrm{~h}$<smiles>C=CC[C@@H](COC)N[C@H](C(C)=O)c1c(OCc2ccccc2)ccc([N+](=O)[O-])c1[O-]</smiles>

$154(\beta-\mathrm{Me} 87 \%)$

$155(\alpha-\mathrm{Me} 87 \%)$

With the triflates 154 and 155 in hand, intramolecular Mizoroki-Heck reaction under Zhou's conditions provided 2-benzazepines 158 and 159 smoothly as expected. Watanabe- 
Cenini-Söderberg reductive $N$-heterocyclization of the nitroaromatic compounds 158 and 159 afforded the benzyl protected analogs of azepinoindoles $\mathbf{1 6 0}$ and $\mathbf{1 6 1}$ in $73 \%$ and 59\% respectively (Scheme 39).

Scheme 39: Intramolecular Heck Reaction and Reductive $N$-heterocylization<smiles>C=CC[C@H](N[C@H](C(C)=O)c1c(OCc2ccccc2)ccc([N+](=O)[O-])c1OCC)C(=O)O</smiles>

$$
\begin{aligned}
& \underset{\mathrm{Pd}(\mathrm{dba})_{2}, 1,10 \text {-phen }}{\mathrm{dppp}, \mathrm{DMF}, \mathrm{CO}(6 \mathrm{~atm})} \\
& 120^{\circ} \mathrm{C}
\end{aligned}
$$

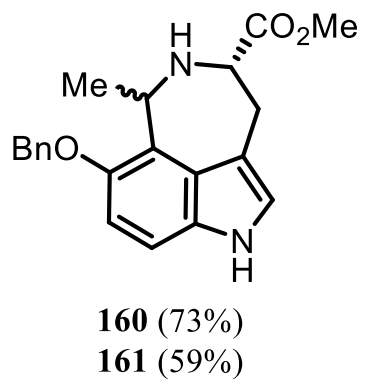

Finally, reduction of azepinoindoles $\mathbf{1 6 0}$ and $\mathbf{1 6 1}$ using $\mathrm{Pd} / \mathrm{C}$ at 1 atm $\mathrm{H}_{2}$ removed the benzyl group as expected to give hyrtioreticulins methyl esters 164 and 165 (Scheme 40). These compounds have previously been hydrolyzed using $10 \% \mathrm{NaOH} / \mathrm{H}_{2} \mathrm{O}$ in methanol to afford hyrtioreticulins C \& D. ${ }^{43 c}$ 
Scheme 40: Synthesis of Hyrtioreticulins C \& D

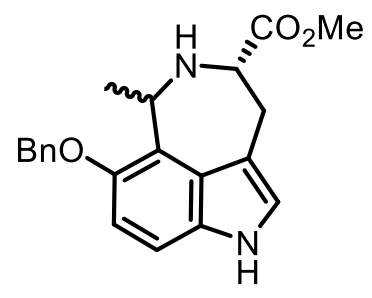

$162(\beta-\mathrm{Me})$

$163(\alpha-\mathrm{Me})$

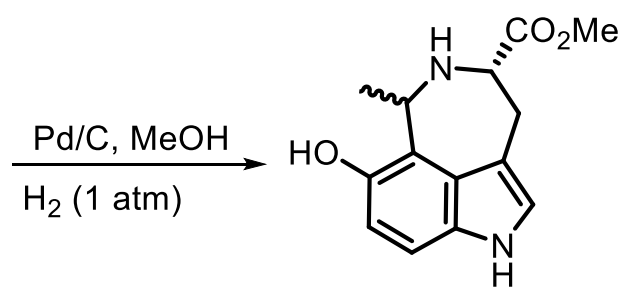

$164(83 \%)$

$165(88 \%)$

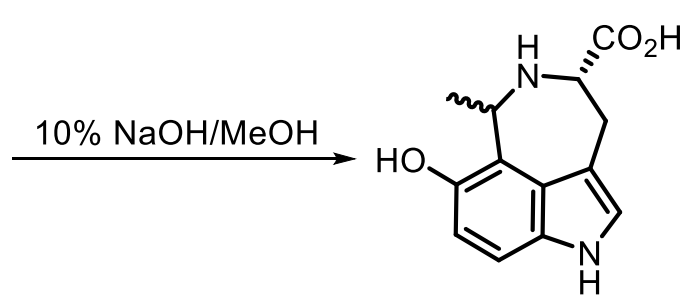

$166(72 \%)$

$167(70 \%)$

\subsection{Conclusions}

A concise linear total syntheses of the naturally occurring azepino[5,4,3-cd]indole diastereomers, hyrtioreticulins $\mathrm{C} \& \mathrm{D}$ has been completed. An imination, trans-imination, a regio-selective intramolecular Mizoroki-Heck reaction and a Watanabe-Cenini- Söderberg reductive $N$-heterocyclization are the key steps in the syntheses. 


\section{Chapter 4}

\section{Attempted Synthesis of Aurantioclavine}

4.1 Introduction to Aurantioclavine $\quad 43$

4.2 Notable syntheses of Aurantioclavine

4.2.1 First synthesis of Aurantioclavine by Somei

43

4.2.2 First Enantioselective Synthesis by Stoltz

4.2.3 Most recent Synthesis by Takemoto 


\subsection{Introduction to Aurantioclavine}

Aurantioclavine 168 was first isolated from the fungus Penicillium aurantiovirens in 1981 by Kozlovskii and coworkers. ${ }^{27}$ This molecule and a related alkaloid, clavicipitic acid 169 isolated from the fungus Claviceps fusiformis, are proposed to be biosynthetic intermediates of the complex polycyclic alkaloids of the communesin family (Figure 8). ${ }^{64}$ Members of this family display notable bioactivities, including insecticidal properties and cytotoxicity toward leukemia cell lines.

Figure 8: Structural Relationship of Aurantioclavine with Communesins 170

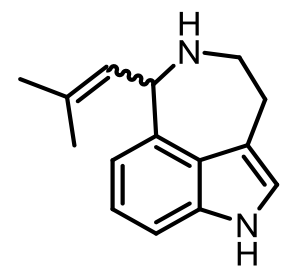

168

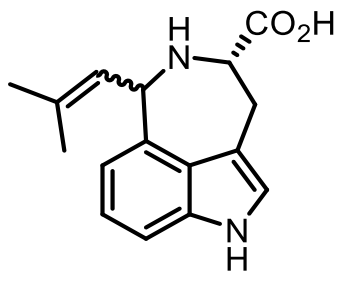

169

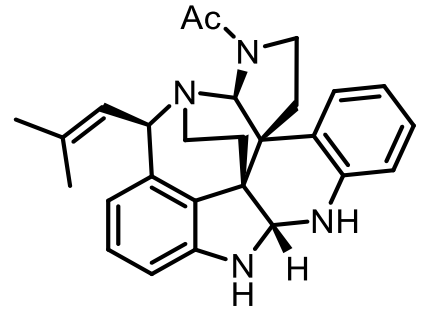

170

\subsection{Notable Syntheses of Aurantioclavine}

After the first total synthesis of aurantioclavine 168 in 1985 by Somei et al., ${ }^{34 a}$ several racemic and enantioselective syntheses have been reported to date. ${ }^{34,35,49}$ Stoltz and coworkers ${ }^{48}$ reported the first enantioselective synthesis and determination of the absolute stereochemistry.

\subsubsection{First Synthesis of Aurantioclavine by Somei}

Somei and coworkers reported the first total synthesis of aurantioclavine (Scheme 41). ${ }^{34 a}$ The starting 3-formylindole 171 was readily converted into nitroethylindole 172. An intermolecular Heck reaction of 4-iodoindole 172 with allylic alcohol 173 provided 174. Finally, 
an intramolecular reductive amination using $\mathrm{Zn}-\mathrm{Hg} / \mathrm{HCl}$ afforded racemic aurantioclavine $\mathbf{1 7 5}$ (Scheme 41).

\section{Scheme 41: Somei's Synthesis of Aurantioclavine}

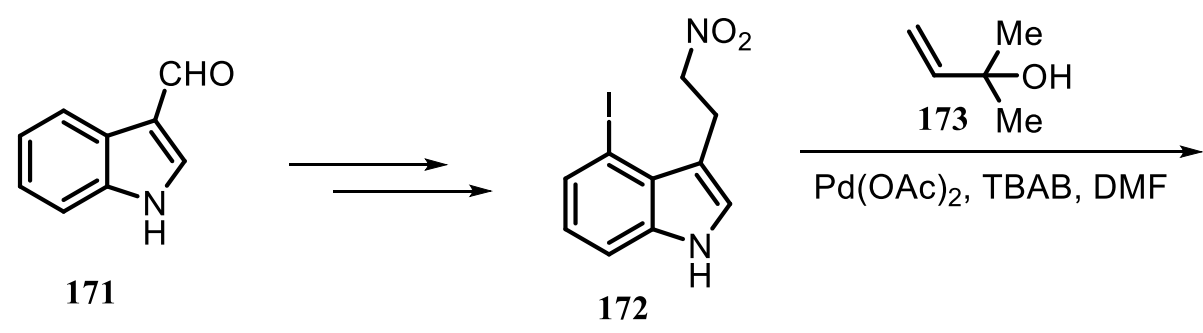

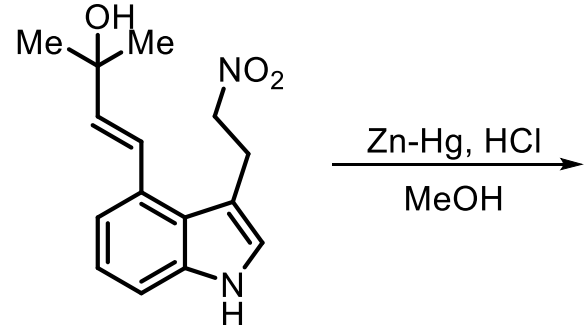

$174(80 \%)$

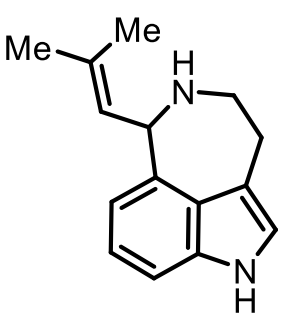

$175(67 \%)$

\subsubsection{First Enantioselective Synthesis by Stoltz}

Stoltz and coworkers ${ }^{48}$ reported the first enantioselective synthesis of (-)-aurantioclavine (Scheme 42). The key reactions were a palladium-catalyzed oxidative kinetic resolution ${ }^{65}$ and an intramolecular Mitsunobu reaction to install the azepine ring.

The starting 4-formylindole $\mathbf{1 7 6}$ was readily converted into racemic diol $\mathbf{1 7 8}$ by the addition of organolithium 177. A palladium-catalyzed oxidative kinetic resolution in presence of chiral ligand (-)-sparteine gave 179 with $96 \%$ ee albeit in low isolated yield. The diol 179 was converted to 181 over five steps which underwent intramolecular Mitsunobu reaction to afford azepinoindole 182 in excellent yield, which after deprotection of tosyl and nosyl groups gave (-)aurantioclavine. Absolute configuration of (-)-aurantioclavine was confirmed by X-ray analysis. 
Scheme 42: Stoltz Synthesis of Aurantioclavine

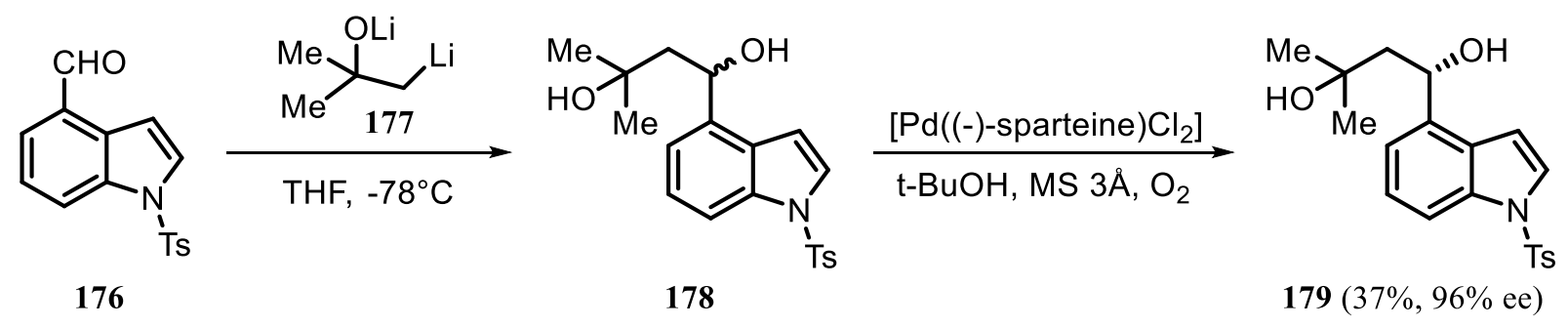<smiles></smiles><smiles>CC(C)=C[C@H]1NCCc2c[nH]c3cccc1c23</smiles>

\subsubsection{Most recent Synthesis by Takemoto}

The most recent scalable synthesis of aurantioclavine was reported by Takemoto and coworkers (Scheme 43). ${ }^{66}$ The hydroxyethylindole 184 was converted to 185 using a Mitsunobu reaction. Removal of Boc group followed by a Suzuki-Miyaura coupling with boronic ester 186 introduced the allylic alcohol unit at the C-4 position. A desilylation using TBAF to afford $\mathbf{1 8 8}$, and a $\mathrm{Mg}\left(\mathrm{ClO}_{4}\right)_{2}$ mediated allylic amination of $\mathbf{1 8 8}$ provided the $N$-tosylated azepinoindole $\mathbf{1 8 9}$, which after removal of the tosyl group gave aurantioclavine $\mathbf{1 9 0 .}$ 
Scheme 43: Concise and Scalable Synthesis by Takemoto<smiles>CN(C(=O)O)C(=O)OCc1c[nH]c2cccc(Br)c12</smiles>

184<smiles>CN(CCc1c[nH]c2cccc(Br)c12)C(=O)OC(C)(C)C</smiles>

$185(62 \%)$
1) TFA, DCM

2)

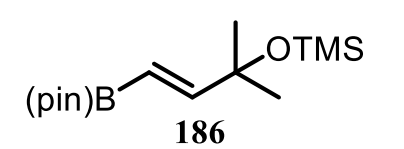

$\mathrm{Pd}\left(\mathrm{PPh}_{3}\right)_{4}, 1,2-\mathrm{DME}$

$\mathrm{Na}_{2} \mathrm{CO}_{3}, 85^{\circ} \mathrm{C}$

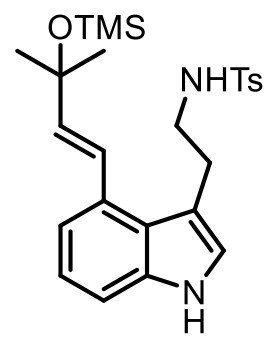

187 ( 2 steps, $49 \%$ )

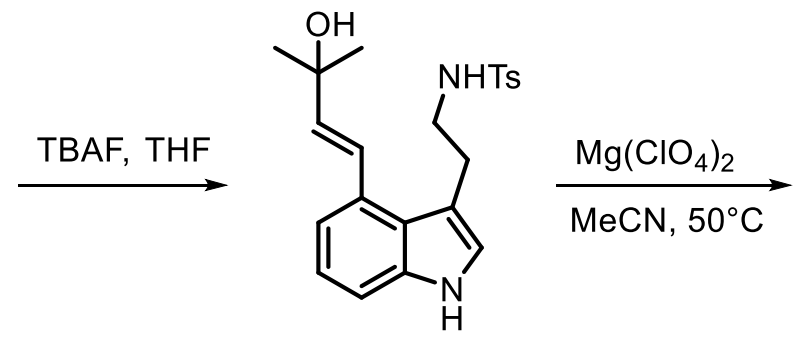

$188(70 \%)$<smiles>CC(C)=CC1c2cccc3[nH]cc(c23)CCN1[AsH3]</smiles>

$189(63 \%)$

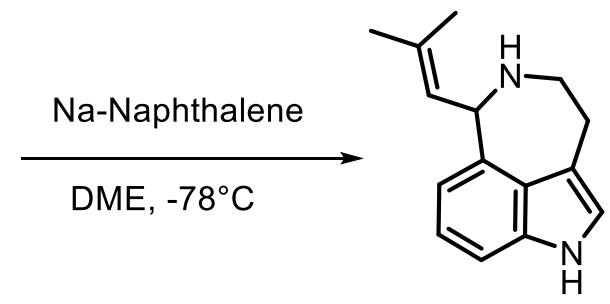

190

\subsection{Attempted Synthesis of Aurantioclavine}

Our comparatively short strategy to synthesize azepinoindoles comprised of three important steps: reductive amination, intramolecular Mizoroki-Heck reaction, and WatanabeCenini-Söderberg reductive $N$-heterocyclization. Since aurantioclavine shares a common azepinoindole framework like fargesine and hyrtioreticulins, we anticipated that similar strategy could be used for its synthesis.

\subsubsection{Retrosynthetic Analysis}

The resemblance of aurantioclavine with the natural products previously synthesized in our lab prompted us to propose a relatively similar synthetic route (Scheme 44). Aurantioclavine possesses a 2-methylpropene substituent at the C-6 position of the ring. Therefore, our synthetic strategy was focused primarily on synthesizing a cyclization precursor having pre-installed 2- 
methylpropene substituent. It was envisioned that aurantioclavine 191 could result from Watanabe-Cenini -Söderberg reductive $N$-heterocyclization of nitroaromatic 192. Intramolecular Mizoroki-Heck reaction of $\mathbf{1 9 3}$ would give the desired reductive $N$-heterocyclization precursor 192. The terminal alkene 193 could be prepared by reductive amination of enone derivative 194 and known 4-amino-1-butene 195. The enone 194 could be obtained by dehydration of aldol adduct 196 which, in turn, could result from a crossed-aldol reaction between known 2-hydroxy3-nitroacetophenone 197 and acetone 198.

\section{Scheme 44: Proposed Retrosynthetic Outline of Aurantioclavine}

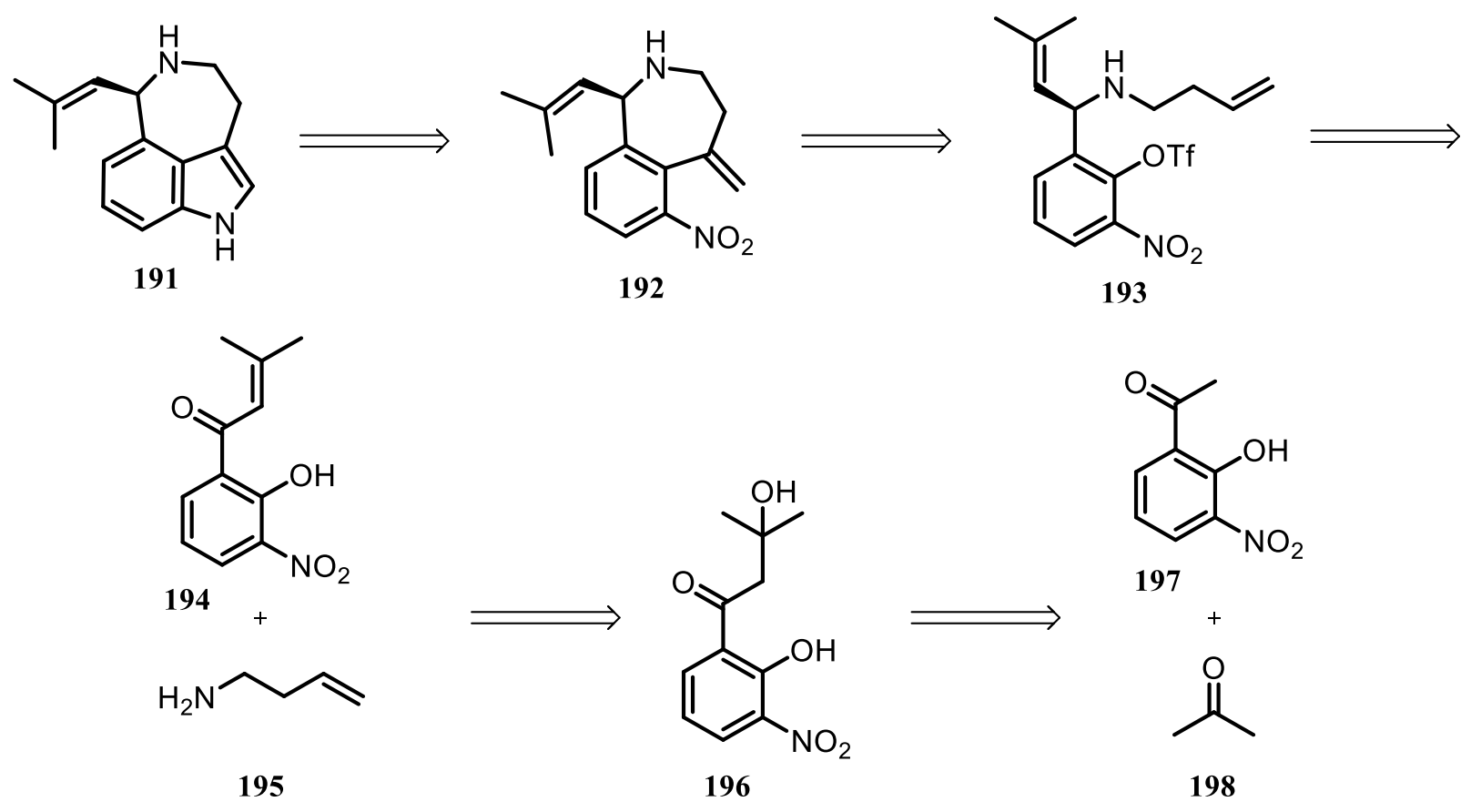

\subsubsection{Results and Discussion}

The synthesis of aurantioclavine began with the crossed aldol reaction between 2hydroxy-3-nitroacetophenone 199 and acetone using LHMDS as a base at $-78{ }^{\circ} \mathrm{C}$ which furnished the expected aldol product $\mathbf{2 0 0}$ in 72\% isolated yield. Dehydration of compound $\mathbf{2 0 0}$ in 
the presence of TFAA and pyridine at $0{ }^{\circ} \mathrm{C}$ went smoothly to afford the enone 201 in excellent yield (Scheme 45).

\section{Scheme 45: Aldol Reaction and Dehydration of the Aldol Product}

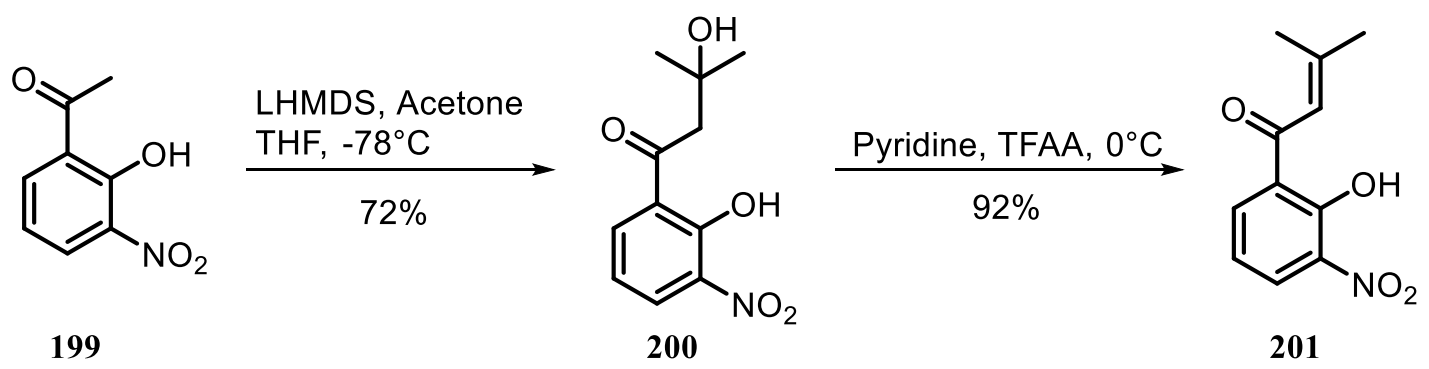

Attempts of reductive amination of $\mathbf{2 0 1}$ with 4-amino-1-butene under various conditions yielded only the undesired retro-aldol product. With a view that dehydration step could be performed after reductive amination, some reductive amination protocols found in the literature were also tried with the ketone 200. Unfortunately, formation of retro-aldol products was even more pronounced in reactions when $\mathbf{2 0 0}$ was used in reactions. Additionally, attempts to protect the phenolic group of $\mathbf{2 0 1}$ with triflic anhydride and pyridine were also unsuccessful. Therefore, the hydroxy group of $\mathbf{2 0 1}$ was protected using $p$-methoxybenzyl chloride (PMBCl) to give $\mathbf{2 0 3}$ in good yield (Scheme 46).

\section{Scheme 46: Protection of Phenol Using PMBCl}<smiles>CC(C)=CC(=O)c1cccc([N+](=O)[O-])c1O</smiles>

201
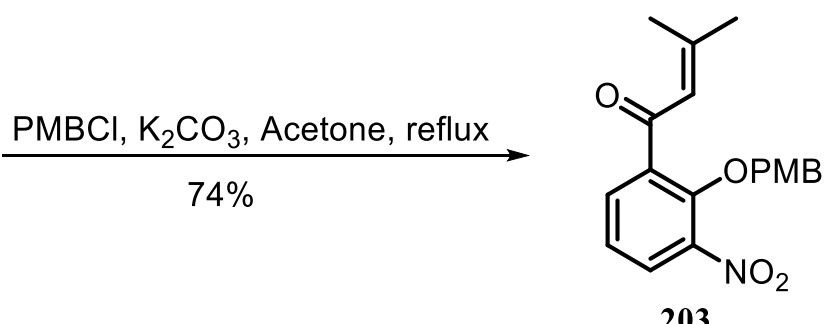

203 
The PMB-protected ketone $\mathbf{2 0 3}$ finally underwent $\mathrm{TiCl}_{4}$-mediated reductive amination with 4-amino-1-butene at $-78{ }^{\circ} \mathrm{C}$ in the presence of sodium borohydride as reducing agent to give the desired amine 205, albeit without the protecting group (Scheme 47). This unexpected removal of $p$-methoxybenzyl group during the reductive amination procedure was beneficial in the sense that it could save the deprotection step.

\section{Scheme 47: Reductive Amination of Enone 203}

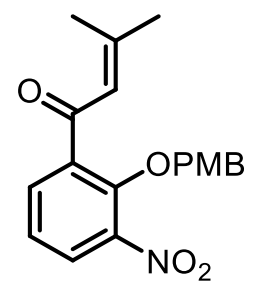

203

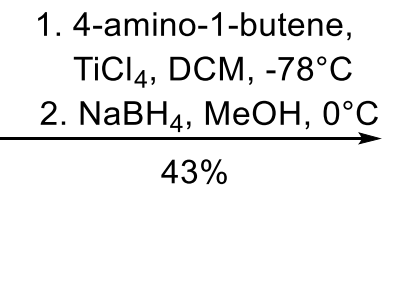

4-amino-1-butene, $\mathrm{TiCl}_{4}, \mathrm{DCM},-78^{\circ} \mathrm{C}$ $43 \%$

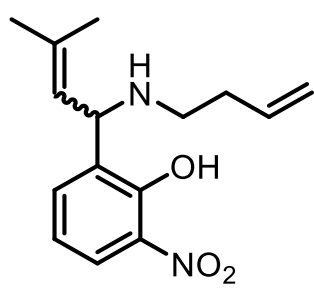

205

The terminal alkene $\mathbf{2 0 5}$, after converting the hydroxy group into triflate, would undergo intramolecular Mizoroki-Heck reaction as evidenced by our previous syntheses (vide supra). Attempts to convert $\mathbf{2 0 5}$ into a triflate as cyclization precursor using triflic anhydride and pyridine at varying temperature conditions were unsuccessful as all our endeavors resulted in decomposed products.

\subsubsection{Conclusions}

A short synthesis of aurantioclavine is currently underway. A crossed-aldol reaction and a $\mathrm{TiCl}_{4}$-mediated reductive amination served as an expedient route to the Heck reaction precursor 205. Further optimization is deemed necessary to perform the Heck reaction, which would, in turn, lead to the azepinoindole alkaloid aurantioclavine. 


\section{Overall Conclusion}

Short synthetic schemes leading to naturally occurring azepino[5,4,3-cd]indole alkaloids cimitrypazepine, fargesine and diastereomeric hyrtioreticulins C \& D have been developed. A terminal alkene-tethered tetra-substituted nitrobenzene analogue served as a key intermediate for a sequential formation for the azepine ring and the pyrrole ring of the natural products.

The intramolecular Mizoroki-Heck reaction using one of the standard catalyst systems, palladium diacetate $-\operatorname{tri}\left(o\right.$-tolyl)phosphine - triethyl amine $\left(125^{\circ} \mathrm{C}\right)$ provided, in addition to the desired seven-membered ring, the eight-membered rings as minor products. Alternatively, intramolecular cyclization of related substrates using bis(dibenzylideneacetone)palladium $\left(\mathrm{Pd}(\mathrm{dba})_{2}\right)$, bis(diphenylphosphino)ferroccene (dppf), and urotropin in $\mathrm{N}, \mathrm{N}$-diemethylacetamide (DMA) provided a seven membered rings as the single product. Thus, our results suggested that the synthesis of both 1,1-disubstituted and 1,2-disubstituted alkenes can be obtained from the same substrate simply by modifying the catalyst system.

The Watanabe-Cenini-Söderberg reductive $N$-heterocyclization served as an efficient late stage cyclization protocol for the syntheses of above mentioned azepinoindole alkaloids. The catalyst system $\mathrm{Pd}(\mathrm{dba})_{2}$-dppp-1,10-phenanthroline using DMF as solvent at $120{ }^{\circ} \mathrm{C}$ under 6 atm of carbon monoxide was successfully utilized in all of the four syntheses to afford the desired indole ring, which further elaborated its synthetic utility for the synthesis of a variety of functionalized indoles. 


\section{Chapter 5}

\section{Supporting Information: Experimental Procedures}

5.1 Supporting Information for Chapter 2: Cimitrypazepine and Fargesine 53

5.2 Supporting Information for Chapter 3: Hyrtioreticulins C \& D 61

5.3 Supporting Information for Chapter 4: Aurantioclavine $\quad 80$ 
General Procedures. NMR spectra were determined in $\mathrm{CDCl}_{3}$ at $600 \mathrm{MHz}\left({ }^{1} \mathrm{H} \mathrm{NMR}\right)$ and 150 $\mathrm{MHz}\left({ }^{13} \mathrm{C} \mathrm{NMR}\right), 400 \mathrm{MHz}\left({ }^{1} \mathrm{H} \mathrm{NMR}\right)$ and $100 \mathrm{MHz}\left({ }^{13} \mathrm{C} \mathrm{NMR}\right)$, or at $270 \mathrm{MHz}\left({ }^{1} \mathrm{H} \mathrm{NMR}\right)$ and 67.5 MHz $\left({ }^{13} \mathrm{C}\right.$ NMR $)$. The chemical shifts are expressed in $\delta+$ values relative to $\mathrm{SiMe}_{4}(0.0$ ppm, ${ }^{1} \mathrm{H}$ and $\left.{ }^{13} \mathrm{C}\right)$ or $\mathrm{CDCl}_{3}\left(77.0 \mathrm{ppm},{ }^{13} \mathrm{C}\right)$ internal standards. ${ }^{1} \mathrm{H}-{ }^{1} \mathrm{H}$ coupling constants are reported as calculated from spectra, thus a slight difference between $J_{\mathrm{a}, \mathrm{b}}$ and $J_{\mathrm{b}, \mathrm{a}}$ is usually observed. Tetrahydrofuran (THF) was distilled from sodium benzophenone ketyl prior to use. Hexanes and ethyl acetate were distilled from calcium hydride. Anhydrous acetonitrile, benzene, dichloromethane, 1,4-dioxane, $N, N$-dimethylformamide, and toluene were used as received. Chemicals prepared according to literature procedures have been footnoted the first time used; all other reagents were obtained from commercial sources and used as received. All reactions were performed under a nitrogen atmosphere in oven-dried glassware. Solvents were removed from reaction mixtures and products on a rotary evaporator at water aspirator pressure unless otherwise stated. Chromatography was performed on silica gel 60 (40-63 $\mu \mathrm{m}$, Sorbtech). Melting points (uncorrected) were recorded directly from products obtained by chromatography. 


\subsection{Supporting Information for Chapter 2: Cimitrypazepine and Fargesine}<smiles>O=Cc1c(O)ccc([N+](=O)[O-])c1I</smiles>

94

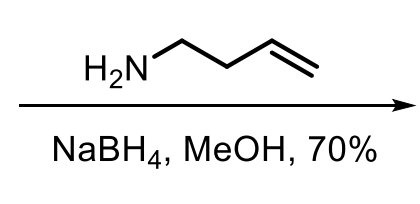

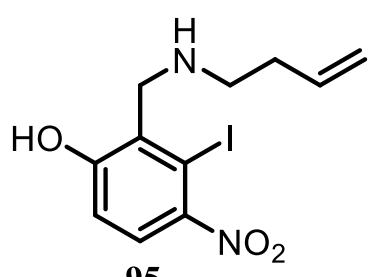

95

To a stirred solution of 6-hydroxy-2-iodo-3-nitrobenzaldehyde (94), (200 mg, 0.682 $\mathrm{mmol})$ and 4-amino-1-butene $(48.5 \mathrm{mg}, 0.682 \mathrm{mmol})$ in methanol $(2.1 \mathrm{~mL})$ at ambient temperature was added $\mathrm{NaBH}_{4}(51.6 \mathrm{mg}, 1.36 \mathrm{mmol})$. The mixture was stirred at ambient temperature for $1 \mathrm{~h}$. Water $(21 \mathrm{~mL})$ was added and the resulting mixture was extracted with EtOAc $(3 \times 25 \mathrm{~mL})$. The combined organic layers were dried $\left(\mathrm{MgSO}_{4}\right)$, filtered and solvents were removed under reduced pressure. The crude product was purified by chromatography $\left(\mathrm{CHCl}_{3} / \mathrm{MeOH} / \mathrm{NH}_{4} \mathrm{OH}, 100: 10: 1\right)$ affording 95 (166 mg, $\left.0.477 \mathrm{mmol}, 70 \%\right)$ as a yellow solid. Analytical data for 95: $\mathrm{mp}=158-160{ }^{\circ} \mathrm{C} ;{ }^{1} \mathrm{H} \mathrm{NMR}\left(400 \mathrm{MHz}, \mathrm{CDCl}_{3}\right) \delta 7.65(\mathrm{~d}, J=8.4 \mathrm{~Hz}, 1 \mathrm{H})$, $7.0($ br s, 2H) $6.80(\mathrm{~d}, J=9.2 \mathrm{~Hz}, 1 \mathrm{H}), 5.77(\mathrm{ddt}, J=17.6,10.4,6.4, \mathrm{~Hz}, 1 \mathrm{H}), 5.17$ (d, $J=18.0 \mathrm{~Hz}$, $1 \mathrm{H}), 5.16(\mathrm{~d}, J=9.2 \mathrm{~Hz}, 1 \mathrm{H}), 4.32(\mathrm{~s}, 2 \mathrm{H}), 2.79(\mathrm{t}, J=6.8 \mathrm{~Hz}, 2 \mathrm{H}), 2.35(\mathrm{q}, J=6.4 \mathrm{~Hz}, 2 \mathrm{H}) ;{ }^{13} \mathrm{C}$ NMR $\left(100 \mathrm{MHz}, \mathrm{CDCl}_{3}\right) \delta 162.7,146.3,134.6,126.1,125.5,118.2,116.8,92.8,58.5,47.2$, 33.2; IR (ATR) 2954, 2874, 2174, 1524, 1453, 1338, 1243, 829, $727 \mathrm{~cm}^{-1}$; HRMS (ESI) calcd for $\mathrm{C}_{11} \mathrm{H}_{14} \mathrm{IN}_{2} \mathrm{O}_{3}\left(\mathrm{M}+\mathrm{H}^{+}\right)$249.0049, found 249.0049. 


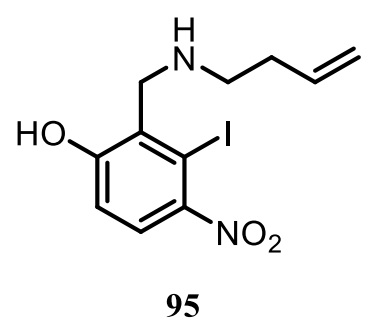

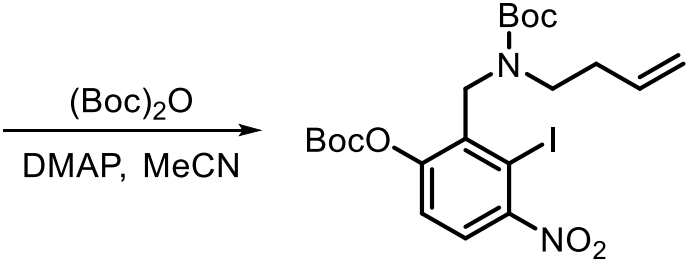

$97(31 \%)$

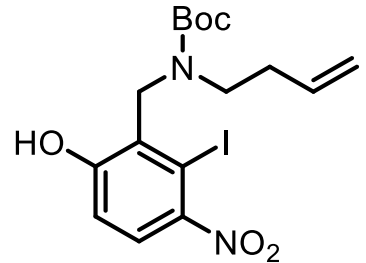

$98(56 \%)$

To a stirred solution of compound $95(166 \mathrm{mg}, 0.477 \mathrm{mmol})$ in acetonitrile (MeCN, 4.8 $\mathrm{mL})$ was added di-t-butyldicarbonate $\left((\mathrm{Boc})_{2} \mathrm{O}, 208 \mathrm{mg}, 0.954 \mathrm{mmol}\right)$ and $4-(N, N-$ dimethylamino)pyridine (DMAP, $11.8 \mathrm{mg}, 0.095 \mathrm{mmol}$ ) at ambient temperature. The mixture was stirred for $18 \mathrm{~h}$. The solvent was removed under reduced pressure and the crude product was dissolved in water $(20 \mathrm{~mL})$. The mixture was extracted with EtOAc $(3 \times 20 \mathrm{~mL})$. The combined organic layers were dried $\left(\mathrm{MgSO}_{4}\right)$, filtered, and the solvents were removed under reduced pressure. The crude product was purified by chromatography (hexanes/EtOAc, 98:2) to give, in order of elution, 97 (82 mg, $0.150 \mathrm{mmol}, 31 \%)$ as a pale-yellow oil and 98 (119 $\mathrm{mg}, 0.265$ mmol, 56\%) as a pale yellow solid. Analytical data for $97:{ }^{1} \mathrm{H} \mathrm{NMR}\left(400 \mathrm{MHz}, \mathrm{CDCl}_{3}, 50{ }^{\circ} \mathrm{C}\right) \delta$ $7.58(\mathrm{~d}, J=9.2 \mathrm{~Hz}, 1 \mathrm{H}), 7.29$ (d, $J=9.2 \mathrm{~Hz}, 1 \mathrm{H}), 5.77$ (ddt, $J=17.2,10.0,6.8, \mathrm{~Hz}, 1 \mathrm{H}), 5.01$ (d, $J=18.8 \mathrm{~Hz}, 1 \mathrm{H}), 4.97(\mathrm{~d}, J=10.0 \mathrm{~Hz}, 1 \mathrm{H}), 4.75(\mathrm{~s}, 2 \mathrm{H}), 3.06(\mathrm{br} \mathrm{s}, 2 \mathrm{H}), 2.22(\mathrm{q}, J=7.2 \mathrm{~Hz}, 2 \mathrm{H})$, $1.56(\mathrm{~s}, 9 \mathrm{H}), 1.47(\mathrm{~s}, 9 \mathrm{H}) ;{ }^{13} \mathrm{C} \mathrm{NMR}\left(100 \mathrm{MHz}, \mathrm{CDCl}_{3}, 60{ }^{\circ} \mathrm{C}\right.$, mixture of rotamers $) \delta 155.1$, $153.5,151.9,150.6,135.9,135.3,124.1,123.4,116.6,93.4,85.1,80.1,50.5,45.7,32.7,28.7$, 28.5,28.3, 27.9, 27.7; IR (ATR) 3082, 2978, 2936, 1760, 1693, $1123 \mathrm{~cm}^{-1}$; HRMS (ESI) calcd for $\mathrm{C}_{21} \mathrm{H}_{30} \mathrm{IN}_{2} \mathrm{O}_{7}\left(\mathrm{M}+\mathrm{H}^{+}\right)$549.1098, found 549.1104.

Analytical data for 98: $\mathrm{mp}=105-106{ }^{\circ} \mathrm{C} ;{ }^{1} \mathrm{H} \mathrm{NMR}\left(400 \mathrm{MHz}, \mathrm{CDCl}_{3}\right) \delta 7.67(\mathrm{~d}, J=9.2 \mathrm{~Hz}, 1 \mathrm{H})$, $6.93(\mathrm{~d}, J=8.8 \mathrm{~Hz}, 1 \mathrm{H}), 5.75(\mathrm{ddt}, J=17.2,10.0,6.8, \mathrm{~Hz}, 1 \mathrm{H}), 5.07-5.01(\mathrm{~m}, 2 \mathrm{H}), 4.82(\mathrm{~s}, 2 \mathrm{H})$, $3.42(\mathrm{t}, J=7.2 \mathrm{~Hz}, 2 \mathrm{H}), 2.34$ (pent, $J=7.6 \mathrm{~Hz}, 2 \mathrm{H}), 1.50(\mathrm{~s}, 9 \mathrm{H}) ;{ }^{13} \mathrm{C} \mathrm{NMR}\left(100 \mathrm{MHz}, \mathrm{CDCl}_{3}\right) \delta$ 160.7, 159.2, 147.6, 134.6, 128.2, 127.4, 118.1, 117.6, 95.7, 83.0, 51.5, 46.5, 32.9, 28.5; IR 
(ATR) 3078, 2980, 2937, 1737, 1641, 1525, $1442 \mathrm{~cm}^{-1}$; HRMS (ESI) calcd for $\mathrm{C}_{16} \mathrm{H}_{22} \mathrm{IN}_{2} \mathrm{O}_{5}$

$\left(\mathrm{M}+\mathrm{H}^{+}\right)$449.0573, found 449.0578.<smiles>C=CCCN(Cc1c(OC(=O)OC(C)(C)C)ccc([N+](=O)[O-])c1I)C(=O)O</smiles>

97

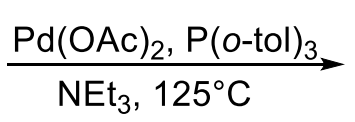<smiles>C=C1CCN(C(=O)OC(C)(C)C)Cc2c(OC(=O)OC(C)(C)C)ccc([N+](=O)[O-])c21</smiles>

101(43\%)<smiles>O=C(c1ccccc1)N1C/C=C\Cc2c([N+](=O)[O-])ccc(O)c2C1</smiles>

$103(8 \%)$<smiles>C=C1CCN(C(=O)c2ccccc2)Cc2c(O)ccc([N+](=O)[O-])c21</smiles>

$102(23 \%)$<smiles>O=C(c1ccccc1)N1CC/C=C\c2c([N+](=O)[O-])ccc(O)c2C1</smiles>

$104(2 \%)$

A solution of 97 (749 mg, $1.37 \mathrm{mmol}), \mathrm{Pd}(\mathrm{OAc})_{2}(15.3 \mathrm{mg}, 0.068 \mathrm{mmol})$, and tri $(o-$ tolyl)phosphine (TTP, $41.4 \mathrm{mg}, 0.136 \mathrm{mmol}$ ) in triethylamine (TEA, $6.8 \mathrm{~mL}$ ) was heated at 125 ${ }^{\circ} \mathrm{C}(2 \mathrm{~h})$. After $2 \mathrm{~h}$, the reaction mixture was cooled to ambient temperature, diluted with ethyl acetate $(10 \mathrm{~mL})$ and filtered (Celite). The filtrate was evaporated to remove the solvents. Purification of the crude product by chromatography (hexanes/EtOAc, 98:2 then 8:2) gave, in order of elution, $101(250 \mathrm{mg}, 0.595 \mathrm{mmol}, 43 \%)$ as pale yellow oil, compound 103 (10 mg, $0.031 \mathrm{mmol}, 2 \%)$ as pale yellow solid, $104(36 \mathrm{mg}, 0.112 \mathrm{mmol}, 8 \%)$ as yellow oil, and 102 (102 $\mathrm{mg}, 0.318 \mathrm{mmol}, 23 \%)$ as yellow solid.<smiles>C=CCCN(Cc1c(O)ccc([N+](=O)[O-])c1I)C(=O)OC(C)(C)C</smiles>

98

$$
\frac{\mathrm{Pd}(\mathrm{OAc})_{2}, \mathrm{P}\left(\mathrm{o}-\mathrm{tol}_{3}\right)_{3}}{\mathrm{NEt}_{3}, 125^{\circ} \mathrm{C}}
$$<smiles>C=C1CCN(C(=O)OC(C)(C)C)Cc2c(O)ccc([N+](=O)[O-])c21</smiles>

$102(58 \%)$<smiles>O=C(c1ccccc1)N1C/C=C\Cc2c([N+](=O)[O-])ccc(O)c2C1</smiles>

103(13\%) 
A solution of $98(132 \mathrm{mg}, 0.295 \mathrm{mmol})$, palladium diacetate $\left(\mathrm{Pd}(\mathrm{OAc})_{2}, 3.3 \mathrm{mg}, 0.015\right.$ mmol), and tri $(o$-tolyl)phosphine (TTP, $9.0 \mathrm{mg}, 0.030 \mathrm{mmol})$ in triethylamine (TEA, $1.5 \mathrm{~mL})$ was heated at $125^{\circ} \mathrm{C}$ for $6 \mathrm{~h}$. The reaction mixture was cooled to ambient temperature, diluted with EtOAc $(10 \mathrm{~mL})$ and filtered (Celite). The solvent was removed under reduced pressure from the filtrate. Purification of the crude product by chromatography (hexanes/EtOAc, 95:5 then 90:10) gave, in order of elution, 103 (12 $\mathrm{mg}, 0.037 \mathrm{mmol}, 13 \%)$ as yellow oil and compound 102 (55 mg, $0.172 \mathrm{mmol}, 58 \%$ ) as yellow solid.

Analytical data for 101: ${ }^{1} \mathrm{H} \mathrm{NMR}\left(600 \mathrm{MHz}, \mathrm{CDCl}_{3},-52{ }^{\circ} \mathrm{C}\right.$, mixture of rotamers $) \delta 7.73(\mathrm{~d}, J=$ $9.0 \mathrm{~Hz}, 1 \mathrm{H}), 7.70(\mathrm{~d}, J=8.9 \mathrm{~Hz}, 1 \mathrm{H}), 7.26(\mathrm{~d}, J=8.9 \mathrm{~Hz}, 1 \mathrm{H}), 7.23(\mathrm{~d}, J=8.9 \mathrm{~Hz}, 1 \mathrm{H}), 5.27(\mathrm{~s}$, 2H), $4.98(\mathrm{~s}, 1 \mathrm{H}), 4.97$ (s, 1H), 4.47 (br s, 2H), 4.21 (br s, 2H) 3.25 (br s, 2H), 3.10 (br s, 2H), 2.60 (br s 2H), 2.52 (br s, 2H), $1.60(\mathrm{~s}, 9 \mathrm{H}), 1.58(\mathrm{~s}, 9 \mathrm{H}), 1.44(\mathrm{~s}, 9 \mathrm{H}), 1.40(\mathrm{~s}, 9 \mathrm{H}) ;{ }^{13} \mathrm{C} \mathrm{NMR}$ $\left(100 \mathrm{MHz}, \mathrm{CDCl}_{3},-52^{\circ} \mathrm{C}\right.$, mixture of rotamers) $\delta 154.2,154.0,151.1,150.9,149.7,149.2$, $146.9,146.7,143.4,143.2,139.9,139.4,131.2,123.6,123.2,122.3,121.1,116.9,116.8,84.6$, $80.5,79.9,50.1,49.9,44.4,44.0,36.3,35.6,28.1,28.0,27.4,27.3$; IR (ATR) 2981, 2936, 2359, 1760, 1694, 1228, $1132 \mathrm{~cm}^{-1}$; HRMS (ESI) calcd for $\mathrm{C}_{16} \mathrm{H}_{22} \mathrm{IN}_{2} \mathrm{O}_{5}\left(\mathrm{M}+\mathrm{H}^{+}\right)$421.1975, found 421.1977 .

Analytical data for 102: $\mathrm{mp}=137-138{ }^{\circ} \mathrm{C} ;{ }^{1} \mathrm{H} \mathrm{NMR}\left(400 \mathrm{MHz}, \mathrm{CDCl}_{3}, 45^{\circ} \mathrm{C}\right) \delta 7.62(\mathrm{~d}, J=8.8$ Hz, 1H), $6.91(\mathrm{~d}, J=8.8 \mathrm{~Hz}, 1 \mathrm{H}), 5.32(\mathrm{~s}, 1 \mathrm{H}), 5.10$ (s, 1H), 4.31 (br s, 2H), 3.77 (br s, 2H), 2.50 $(\mathrm{t}, J=5.6 \mathrm{~Hz}, 2 \mathrm{H}), 1.43(\mathrm{~s}, 9 \mathrm{H}) ;{ }^{13} \mathrm{C} \mathrm{NMR}\left(100 \mathrm{MHz}, \mathrm{CDCl}_{3}, 45^{\circ} \mathrm{C}\right) \delta 158.2,156.7,143.2$, 142.0, 140.1, 124.9, 124.7, 81.7, 51.1, 44.6, 37.0, 28.3; IR (ATR) 3221, 2981, 2933, 1695, 1652 , 1577, 1520, 1457, 1423, $1307 \mathrm{~cm}^{-1}$; HRMS (ESI) calcd for $\mathrm{C}_{16} \mathrm{H}_{21} \mathrm{~N}_{2} \mathrm{O}_{5}\left(\mathrm{M}+\mathrm{H}^{+}\right) 321.1450$, found 321.1451. 
Analytical data for 103: ${ }^{1} \mathrm{H}$ NMR $\left(600 \mathrm{MHz}, \mathrm{CDCl}_{3}\right) \delta 10.40(\mathrm{~s}, 1 \mathrm{H}), 7.78(\mathrm{~d}, J=8.4 \mathrm{~Hz}, 1 \mathrm{H})$, $6.89(\mathrm{~d}, J=9.0 \mathrm{~Hz}, 1 \mathrm{H}), 6.36(\mathrm{dt}, J=10.1,8.4 \mathrm{~Hz}, 1 \mathrm{H}), 5.83(\mathrm{dt}, J=10.1,7.2 \mathrm{~Hz}, 1 \mathrm{H}), 4.69(\mathrm{~s}$, 2H), $4.14(\mathrm{~d}, J=7.2 \mathrm{~Hz}, 2 \mathrm{H}), 3.74(\mathrm{~d}, J=7.8 \mathrm{~Hz}, 2 \mathrm{H}), 1.43(\mathrm{~s}, 9 \mathrm{H}) ;{ }^{13} \mathrm{C} \mathrm{NMR}\left(150 \mathrm{MHz}, \mathrm{CDCl}_{3}\right)$ $\delta 161.3,157.6,142.7,138.8,136.6,127.5,126.5,125.4,117.5,82.3,46.7,46.2,29.4,28.5 ;$ IR (ATR) 3099, 2978, 2934, 1711, 1641, 1519, 1423, $1264 \mathrm{~cm}^{-1}$; HRMS (ESI) calcd for $\mathrm{C}_{16} \mathrm{H}_{21} \mathrm{~N}_{2} \mathrm{O}_{5}\left(\mathrm{M}+\mathrm{H}^{+}\right) 321.1450$, found 321.1446.

Analytical data for 104: $\mathrm{mp} 154-155{ }^{\circ} \mathrm{C} ;{ }^{1} \mathrm{H}$ NMR $\left(600 \mathrm{MHz}, \mathrm{CDCl}_{3}\right) \delta 11.52(\mathrm{~s}, 1 \mathrm{H}), 8.10(\mathrm{~d}$, $J=9.6 \mathrm{~Hz}, 1 \mathrm{H}), 7.03(\mathrm{~d}, J=10.8 \mathrm{~Hz}, 1 \mathrm{H}), 6.96(\mathrm{~d}, J=9.6 \mathrm{~Hz}, 1 \mathrm{H}), 6.14(\mathrm{dt}, J=11.4,8.4 \mathrm{~Hz}, 1 \mathrm{H})$, 4.89 (br s, 1H), 4.09 (br s, 1H), 3.76 (br s, 1H), 2.71 (br s, 1H), 2.47 (br s, 1H), 1.81 (br s, 1H), $1.49(\mathrm{~s}, 9 \mathrm{H}) ;{ }^{13} \mathrm{C} \mathrm{NMR}\left(150 \mathrm{MHz}, \mathrm{CDCl}_{3}\right) \delta 162.7,158.2,140.1,134.6,131.4,128.5,127.6$, 124.4, 117.3, 82.9, 43.9, 41.4, 28.6, 28.4; IR (ATR) 2980, 2934, 2871, 2720, 2632, 1641, 1520, $1449 \mathrm{~cm}^{-1}$; HRMS (ESI) calcd for $\mathrm{C}_{16} \mathrm{H}_{21} \mathrm{~N}_{2} \mathrm{O}_{5}\left(\mathrm{M}+\mathrm{H}^{+}\right)$321.1450, found 321.1446.

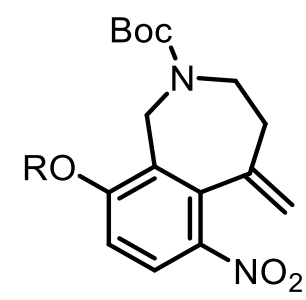

$101(\mathrm{R}=\mathrm{Boc})$ $102(\mathrm{R}=\mathrm{H})$

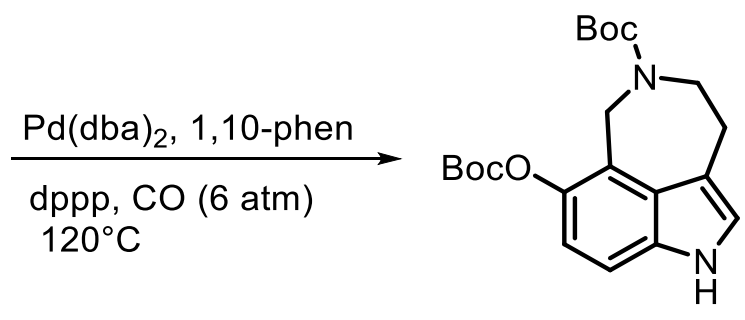

$105(50 \%)$

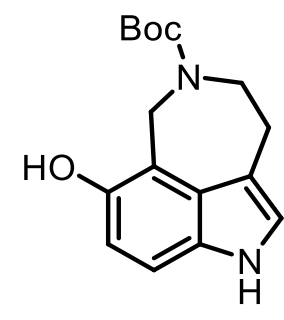

$106(29 \%)$ $106(60 \%)$

A solution of 101 (102 mg, $0.243 \mathrm{mmol})$, bi(dibenzylidenacetone)palladium (13.9 mg, $0.024 \mathrm{mmol}), 1,3$-bis(diphenylphosphino)propane (10 mg, $0.024 \mathrm{mmol}$ ), and 1,10phenanthroline $(8.7 \mathrm{mg}, 0.048 \mathrm{mmol})$ in anhydrous $N, N$-dimethylformamide $(1.3 \mathrm{~mL})$, in an ACE-Glass pressure tube fitted with a pressure head, was saturated with carbon monoxide (4 cycles to $6 \mathrm{~atm}$ of $\mathrm{CO})$. The reaction mixture was stirred under $\mathrm{CO}(6 \mathrm{~atm})$ at $120^{\circ} \mathrm{C}$ for $20 \mathrm{~h}$. The mixture was cooled to ambient temperature, diluted with EtOAc $(5 \mathrm{~mL})$, and washed with 
brine $(3 \times 5 \mathrm{~mL})$. The organic phase was dried $\left(\mathrm{MgSO}_{4}\right)$ and filtered. The solvent was removed under reduced pressure and the resulting residue was purified by chromatography (hexanes/EtOAc, 9:1 then 4:1) to afford, in order of elution, 105 (47 mg, $0.12 \mathrm{mmol}, 50 \%)$ as a pale yellow solid and 106 (20 mg, $0.069 \mathrm{mmol}, 29 \%)$ as a pale yellow solid.

A solution of 102 (48.0 mg, $0.150 \mathrm{mmol})$, bis(dibenzylideneacetone)-palladium (6.0 mg, $0.010 \mathrm{mmol}), 1,3-$ bis(diphenylphosphino)propane ( $4.3 \mathrm{mg}, 0.010 \mathrm{mmol})$, and 1,10phenanthroline $(3.8 \mathrm{mg}, 0.021 \mathrm{mmol})$ in anhydrous $N, N$-dimethylformamide $(0.6 \mathrm{~mL})$, in an ACE-Glass pressure tube fitted with a pressure head, was saturated with carbon monoxide (4 cycles to $6 \mathrm{~atm}$ of $\mathrm{CO})$. The reaction mixture was stirred under $\mathrm{CO}(6 \mathrm{~atm})$ at $120^{\circ} \mathrm{C}$ for $72 \mathrm{~h}$. The mixture was cooled to ambient temperature, diluted with EtOAc $(3 \mathrm{~mL})$, and washed with brine $(3 \times 3 \mathrm{~mL})$. The organic phase was dried $\left(\mathrm{MgSO}_{4}\right)$ and filtered. The solvent was removed under reduced pressure and the resulting residue was purified by chromatography (hexanes/EtOAc, 4:1) to afford $\mathbf{1 0 6}(26 \mathrm{mg}, 0.09 \mathrm{mmol}, 60 \%)$ as a pale yellow solid. Analytical data for $\mathbf{1 0 5}$ from a mixture of rotamers: $\mathrm{mp}=153-155^{\circ} \mathrm{C} ;{ }^{1} \mathrm{H}$ NMR $(400 \mathrm{MHz}$, $\left.\mathrm{CDCl}_{3}\right) \delta 8.20(\mathrm{br} \mathrm{s}, 1 \mathrm{H}), 7.16(\mathrm{~d}, J=8.8 \mathrm{~Hz}, 0.5 \mathrm{H}), 7.15(\mathrm{~d}, J=9.2 \mathrm{~Hz}, 0.5 \mathrm{H}), 6.97(\mathrm{~s}, 1 \mathrm{H}), 6.90$ (d, $J=8.8 \mathrm{~Hz}, 1 \mathrm{H}), 4.90(\mathrm{~s}, 1 \mathrm{H}), 4.82(\mathrm{~s}, 1 \mathrm{H}), 3.76(\mathrm{t}, J=6.0 \mathrm{~Hz}, 1 \mathrm{H}), 3.71(\mathrm{t}, J=4.8,1 \mathrm{H}), 3.14(\mathrm{t}$, $J=5.6 \mathrm{~Hz}, 1 \mathrm{H}), 3.10(\mathrm{t}, J=4.8 \mathrm{~Hz}, 1 \mathrm{H}), 1.58(\mathrm{~s}, 4.5 \mathrm{H}), 1.55(\mathrm{~s}, 4.5 \mathrm{H}), 1.46(\mathrm{~s}, 4.5 \mathrm{H}), 1.39(\mathrm{~s}$, $4.5 \mathrm{H}) ;{ }^{13} \mathrm{C} \mathrm{NMR}\left(100 \mathrm{MHz}, \mathrm{CDCl}_{3}\right) \delta 155.3,155.0,152.9,152.8,140.9,140.5,135.0,134.8$, $125.9,125.8,124.4,124.2,122.8,122.6,116.4,116.3,115.5,115.2,110.1,109.9,83.2,83.2$, 80.0, 79.8, 49.1, 48.3, 47.8, 28.8, 28.6, 28.0, 27.9, 27.7, 26.6; IR (ATR) 3315, 2978, 2935, 1752, 1693, 1669, $1140 \mathrm{~cm}^{-1}$; HRMS (ESI) calcd for $\mathrm{C}_{21} \mathrm{H}_{29} \mathrm{~N}_{2} \mathrm{O}_{5}\left(\mathrm{M}+\mathrm{H}^{+}\right)$389.2076, found 389.2078 . Analytical data for 106: $\mathrm{mp}=186-188^{\circ} \mathrm{C} ;{ }^{1} \mathrm{H} \mathrm{NMR}\left(400 \mathrm{MHz}, \mathrm{CDCl}_{3}, 60^{\circ} \mathrm{C}\right) \delta 7.82(\mathrm{br} \mathrm{s}, 1 \mathrm{H})$, $7.06(\mathrm{~d}, J=8.4 \mathrm{~Hz}, 1 \mathrm{H}), 6.96(\mathrm{~s}, 1 \mathrm{H}), 6.68(\mathrm{~d}, J=8.4 \mathrm{~Hz}, 1 \mathrm{H}), 4.93(\mathrm{~s}, 2 \mathrm{H}), 3.77$ (br s, 2H), 3.14 
(br s, 2H), $1.45(\mathrm{~s}, 9 \mathrm{H}) ;{ }^{13} \mathrm{C} \mathrm{NMR}\left(100 \mathrm{MHz}, \mathrm{CDCl}_{3}\right.$, mixture of rotamers) $\delta 155.0,146.0,145.7$, 131.8, 126.1, 125.9, 122.2, 122.0, 116.9, 113.8, 113.4, 112.0, 111.6, 109.4, 79.2, 79.1, 49.0, 48.9, 48.4, 48.0, 40.4, 40.2, 40.0, 39.8, 39.6, 28.5, 28.4, 27.5, 26.7; IR (ATR) 3335, 2972, 1665, 1582, 1367, $1165 \mathrm{~cm}^{-1}$; HRMS (ESI) calcd for $\mathrm{C}_{16} \mathrm{H}_{21} \mathrm{~N}_{2} \mathrm{O}_{3}\left(\mathrm{M}+\mathrm{H}^{+}\right)$289.1552, found 289.1552 .

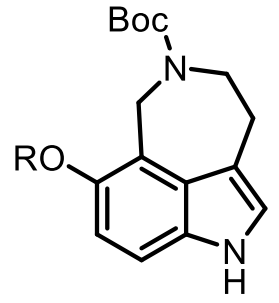

$105(\mathrm{R}=\mathrm{Boc})$ $106(\mathrm{R}=\mathrm{H})$
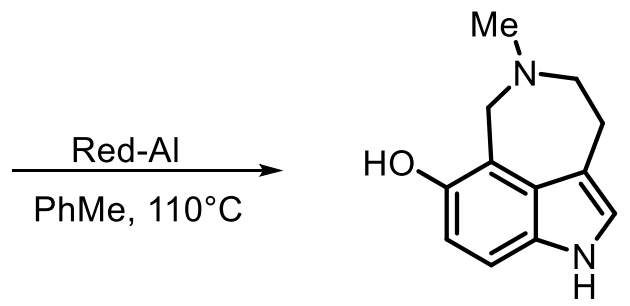

$\mathbf{8 8}(74 \%)$ $\mathbf{8 8}(95 \%)$

To a solution of $\mathbf{1 0 5}(110 \mathrm{mg}, 0.283 \mathrm{mmol})$ in anhydrous toluene $(28 \mathrm{~mL})$ under a nitrogen atmosphere was added sodium bis(2-methoxyethoxy)aluminumhydride (in toluene $\sim 3.5$ $\mathrm{M}, 1.9 \mathrm{~mL}, 6.65 \mathrm{mmol}$ ) drop wise. The mixture was stirred at $110^{\circ} \mathrm{C}$ for $3 \mathrm{~h}$ and then allowed to cool to ambient temperature. Brine $(56 \mathrm{~mL})$ was added, and the mixture was extracted with EtOAc $(3 \times 60 \mathrm{~mL})$. The organic phases were combined, dried $\left(\mathrm{MgSO}_{4}\right)$, and filtered. The solvent was removed under reduced pressure and the residue was purified by chromatography (EtOAc/MeOH, 9:1) to give $\mathbf{8 8}$ (42 $\mathrm{mg}, 0.21 \mathrm{mmol}, 74 \%$ ) as yellow paste.

To a solution of $\mathbf{1 0 6}(218 \mathrm{mg}, 0.756 \mathrm{mmol})$ in a mixture of toluene $(70 \mathrm{~mL})$ and tetrahydrofuran $(5 \mathrm{~mL})$ under a nitrogen atmosphere was added sodium bis(2methoxyethoxy)aluminumhydride (in toluene $\sim 3.5 \mathrm{M}, 5.07 \mathrm{~mL}, 17.7 \mathrm{mmol}$ ) drop wise. The mixture was stirred at $110^{\circ} \mathrm{C}$ for $4 \mathrm{~h}$ and then allowed to cool to ambient temperature. Brine $(150 \mathrm{~mL})$ was added, and the mixture was extracted with EtOAc $(3 \times 150 \mathrm{~mL})$. The organic phases were combined, dried $\left(\mathrm{MgSO}_{4}\right)$, and filtered. The solvent was removed under reduced 
pressure and the resulting residue was purified by chromatography (EtOAc/MeOH, 9:1) to give $\mathbf{8 8}$ (145 $\mathrm{mg}, 0.717 \mathrm{mmol}, 95 \%)$ as a yellow paste.

Analytical data for 88: ${ }^{1} \mathrm{H}$ NMR $\left(400 \mathrm{MHz}, \mathrm{CD}_{3} \mathrm{OD}\right) \delta 7.08(\mathrm{~d}, J=8.8 \mathrm{~Hz}, 1 \mathrm{H}), 7.00(\mathrm{~s}, 1 \mathrm{H})$, $6.67(\mathrm{~d}, J=8.8 \mathrm{~Hz}, 1 \mathrm{H}), 4.26(\mathrm{~s}, 2 \mathrm{H}), 3.22(\mathrm{t}$ with further fine splittings, $J=5.2 \mathrm{~Hz}, 2 \mathrm{H}), 3.12(\mathrm{t}$ with further fine splittings, $J=5.6 \mathrm{~Hz}, 2 \mathrm{H}), 2.68(\mathrm{~s}, 3 \mathrm{H}) ;{ }^{13} \mathrm{C} \mathrm{NMR}\left(100 \mathrm{MHz}, \mathrm{CD}_{3} \mathrm{OD}\right) \delta 148.9$, 132.9, 127.0, 124.5, 113.4, 112.5, 110.9, 107.5, 60.6, 57.8, 44.9, 24.4; IR (ATR) 3284, 2913, 1704, 1583, 1437, 1363, $789 \mathrm{~cm}^{-1}$; HRMS (ESI) calcd for $\mathrm{C}_{12} \mathrm{H}_{15} \mathrm{~N}_{2} \mathrm{O}_{2}\left(\mathrm{M}+\mathrm{H}^{+}\right)$203.1184, found 203.1182.

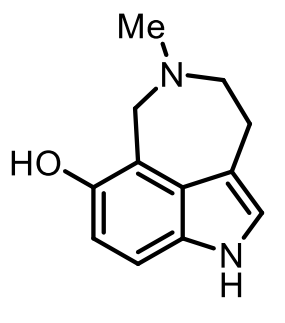

88

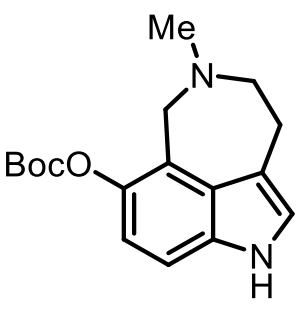

$107(84 \%)$

To a stirred solution of $\mathbf{8 8}(20 \mathrm{mg}, 0.099 \mathrm{mmol})$ in $\mathrm{MeCN}(1.0 \mathrm{~mL})$ was added DMAP $(1.3 \mathrm{mg}, 0.010 \mathrm{mmol})$ at ambient temperature. The mixture was cooled to $0{ }^{\circ} \mathrm{C}$ and $(\mathrm{Boc})_{2} \mathrm{O}$ (23.7 $\mathrm{mg}, 0.108 \mathrm{mmol})$ as a solution of $\mathrm{MeCN}(0.5 \mathrm{~mL})$ was added in portions. The resulting mixture was stirred at $0{ }^{\circ} \mathrm{C}$ for $6 \mathrm{~h}$. The solvent was removed under reduced pressure and the crude product was purified by chromatography $\left(\mathrm{CH}_{2} \mathrm{Cl}_{2} / \mathrm{MeOH}, 20: 1\right)$ to afford 107 (25 $\mathrm{mg}$, $0.083 \mathrm{mmol}, 84 \%$ ) as yellow oil. ${ }^{1} \mathrm{H}$ NMR and ${ }^{13} \mathrm{C}$ NMR data were in accordance with literature value. HRMS (ESI) calcd for $\mathrm{C}_{17} \mathrm{H}_{23} \mathrm{~N}_{2} \mathrm{O}_{3}\left(\mathrm{M}+\mathrm{H}^{+}\right)$303.1709, found 303.1708 . 


\subsection{Supporting Information for Chapter 3: Hyrtioreticulins C \& D}

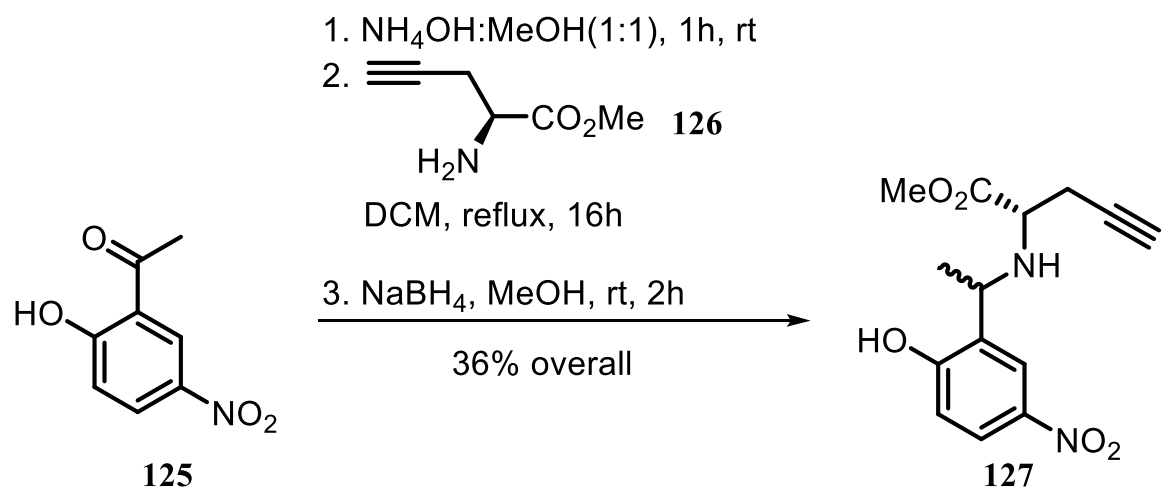

A solution of $\mathrm{NH}_{4} \mathrm{OH}$ and $\mathrm{MeOH}(1: 1, \mathrm{v} / \mathrm{v})(1.7 \mathrm{~mL})$ was added dropwise to 2-hydroxy3-nitroacetophenone 126 (1.825 g, $10.07 \mathrm{mmol})$ at ambient temperature. The resulting mixture was stirred for $2 \mathrm{~h}$ and the solvents were removed under reduced pressure to obtain yellow solid. The crude imine was dissolved in dichloromethane $(50 \mathrm{~mL})$, and $(\mathrm{S})$-2-amino-4-pentynoic acid methyl ester hydrochloride $(2.45 \mathrm{~g}, 14.95 \mathrm{mmol})$ and triethylamine $(1.51 \mathrm{~g}, 14.95 \mathrm{mmol})$ were added. The mixture was stirred at ambient temperature for $21 \mathrm{~h}$. Solvents were removed under reduced pressure and the crude product was dissolved in methanol $(50 \mathrm{~mL})$. To the stirred mixture at ambient temperature was added $\mathrm{NaBH}_{4}(575 \mathrm{mg}, 14.95 \mathrm{mmol})$ in one portion. The resulting mixture was stirred for $2 \mathrm{~h}$ at ambient temperature. The volatiles were removed under reduced pressure and the crude product was purified by chromatography $\left(\mathrm{DCM} / \mathrm{MeOH} / \mathrm{NH}_{4} \mathrm{OH}\right.$, 100:2:1) to afford 127 as an inseparable mixture of diastereomers $(1.041 \mathrm{~g}, 3.56 \mathrm{mmol}, 36 \%$ overall) as yellow solid.

Analytical data for 127: $\mathrm{mp}=87-88^{\circ} \mathrm{C} ;{ }^{1} \mathrm{H} \mathrm{NMR}\left(400 \mathrm{MHz}, \mathrm{CDCl}_{3}\right)$ (as a mixture of diastereomers) $\delta 11.85$ (br s, 1H) 11.75 (br s, 1H), 8.09 (t with further splitting, $J=2.8 \mathrm{~Hz}, 1 \mathrm{H}$ ), 8.06 (t with further splitting, $J=3.2 \mathrm{~Hz}, 1 \mathrm{H}), 7.95(\mathrm{~d}, J=2.8 \mathrm{~Hz}, 1 \mathrm{H}), 7.88(\mathrm{~d}, J=2.8 \mathrm{~Hz}, 1 \mathrm{H})$, $6.88(\mathrm{~d}, J=9.2 \mathrm{~Hz}, 1 \mathrm{H}), 6.87(\mathrm{~d}, J=9.2 \mathrm{~Hz}, 1 \mathrm{H}), 4.18$ (q, $J=6.8 \mathrm{~Hz}, 1 \mathrm{H}), 3.99$ (q, $J=6.8 \mathrm{~Hz}, 1 \mathrm{H})$, 
$3.82(\mathrm{~s}, 3 \mathrm{H}), 3.77(\mathrm{~s}, 3 \mathrm{H}), 3.56(\mathrm{~m}, 1 \mathrm{H}), 3.38(\mathrm{~m}, 1 \mathrm{H}), 2.72(\mathrm{~m}, 6 \mathrm{H}), 2.16(\mathrm{t}, J=2.4 \mathrm{~Hz}, 1 \mathrm{H}), 2.12$ $(\mathrm{t}, J=2.4 \mathrm{~Hz}, 1 \mathrm{H}), 1.53(\mathrm{~d}, J=2.8 \mathrm{~Hz}, 3 \mathrm{H}), 1.52(\mathrm{~d}, J=3.2 \mathrm{~Hz}, 3 \mathrm{H}) ;{ }^{13} \mathrm{C} \mathrm{NMR}\left(100 \mathrm{MHz}, \mathrm{CDCl}_{3}\right)$ (as a mixture of diastereomers) $\delta 172.3,171.7,163.7,163.6,140.6,140.6,126.5,126.2,125.5$, $125.4,125.0,124.4,117.8,117.8,77.8,73.0,72.8,57.9,57.9,56.8,55.5,55.1,55.0,53.0,29.9$, 23.7, 22.7, 21.7, 21.3; IR (ATR) 3326, 2943, 2229, 2117, 1736, 1544, 1452, 1094, $925 \mathrm{~cm}^{-1}$; HRMS (ESI) calcd for $\mathrm{C}_{14} \mathrm{H}_{17} \mathrm{~N}_{2} \mathrm{O}_{5}\left(\mathrm{M}+\mathrm{H}^{+}\right)$293.1137, found 293.1131

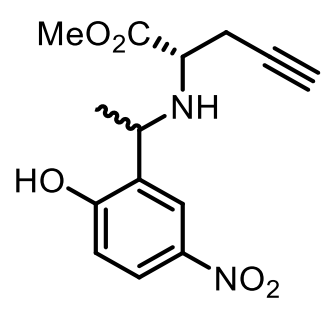

127

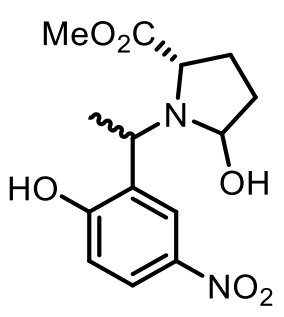

128

In an ACE-Glass pressure tube, $127(102 \mathrm{mg}, 0.349 \mathrm{mmol})$, pivalic acid (178 mg, 1.745 mmol), $t$-amyl alcohol (3.6 mL), and pentamethylcyclopentadienylrhodium(III) chloride dimer $\left(\left[\mathrm{Rh}\left(\mathrm{C}_{5} \mathrm{Me}_{5}\right) \mathrm{Cl}_{2}\right]_{2}\right)(5.4 \mathrm{mg}, 0.009 \mathrm{mmol})$ were added respectively. To the stirred mixture was added silver hexafluoroantimonate $\left[\mathrm{AgSbF}_{6}\right](12.0 \mathrm{mg}, 0.035 \mathrm{mmol})$ and the pressure tube was capped tightly. The resulting mixture was stirred at $120^{\circ} \mathrm{C}$ for $4 \mathrm{~h}$. The reaction mixture was cooled at ambient temperature and filtered through a pad of silica gel. Solvents were removed under reduced pressure from the filtrate and the crude product was purified by chromatography (MeOH/DCM, 4:96) to afford $\mathbf{1 2 8}(46 \mathrm{mg}, 0.15 \mathrm{mmol}, 43 \%)$ as a grey solid.

Analytical data for 128: $\mathrm{mp}=74-75{ }^{\circ} \mathrm{C} ;{ }^{1} \mathrm{H}$ NMR $\left(400 \mathrm{MHz}, \mathrm{CDCl}_{3}\right) \delta 8.01(\mathrm{dd}, J=9.2,2.8 \mathrm{~Hz}$, 2H), $7.97(\mathrm{~d}, J=2.8 \mathrm{~Hz}, 1 \mathrm{H}), 6.83(\mathrm{~d}, J=9.2 \mathrm{~Hz}, 1 \mathrm{H}), 5.41(\mathrm{~d}, J=3.6 \mathrm{~Hz}, 1 \mathrm{H}), 4.08$ (q, $J=7.2 \mathrm{~Hz}$ $1 \mathrm{H}), 3.76(\mathrm{~s}, 3 \mathrm{H}), 3.54(\mathrm{dd}, J=10.2,6.0 \mathrm{~Hz}, 1 \mathrm{H}), 2.25(\mathrm{~m}, 4 \mathrm{H}), 1.58(\mathrm{~d}, J=6.8 \mathrm{~Hz}, 3 \mathrm{H}) ;{ }^{13} \mathrm{C}$ NMR (100 MHz, $\left.\mathrm{CDCl}_{3}\right) \delta 173.6,159.1,141.1,124.4,124.1,123.7,117.6,88.2,62.2,52.5$, 
50.5, 30.9, 25.9, 24.6; IR (ATR) 3327, 2243, 2229, 2071, 1739, 1599, 1498, 1360, 1241, 1094, $925 \mathrm{~cm}^{-1}$.<smiles>COc1cccc(O)c1C(C)=O</smiles>

135

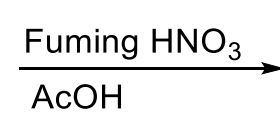<smiles>COc1c([N+](=O)[O-])cc([N+](=O)[O-])c(O)c1C(C)=O</smiles>

137 (7\%)<smiles>COc1ccc([N+](=O)[O-])c(O)c1C(C)=O</smiles>

$138(32 \%)$

2-Hydroxy-6-methoxyacetophenone (3.32 g, $20.0 \mathrm{mmol})$ was dissolved in glacial acetic acid $(20 \mathrm{~mL})$ and fuming nitric acid $(2.0 \mathrm{~mL})$ was added dropwise. The reaction mixture was stirred in a round-bottomed flask equipped with a drying tube $\left(\mathrm{CaCl}_{2}\right)$ at room temperature for $40 \mathrm{~min}$, and then at $50{ }^{\circ} \mathrm{C}$ for $18 \mathrm{~h}$. The solvents were removed under reduced pressure, and water $(80 \mathrm{~mL})$ was added. The mixture was extracted with EtOAc $(3 \times 80 \mathrm{~mL})$. The combined organic layers were dried $\left(\mathrm{MgSO}_{4}\right)$, filtered and solvents were removed under reduced pressure. The crude product was purified by chromatography (EtOAc/hexane, 2:8) affording, in the order of elution, 136 (321 mg, $1.23 \mathrm{mmol}, 6 \%)$ as a yellow solid and 137 (369 mg, $1.44 \mathrm{mmol}, 7 \%)$ as yellow solid and $\mathbf{1 3 8}(1.35 \mathrm{~g}, 6.40 \mathrm{mmol}, 32 \%)$ as a yellow solid.

Analytical data for 136: $\mathrm{mp}=68-69^{\circ} \mathrm{C} ;{ }^{1} \mathrm{H} \mathrm{NMR}\left(400 \mathrm{MHz}, \mathrm{CDCl}_{3}\right) \delta 13.32(\mathrm{~s}, 1 \mathrm{H}), 8.06(\mathrm{~d}, J=$ $9.6 \mathrm{~Hz}, 1 \mathrm{H}), 6.81(\mathrm{~d}, J=9.2 \mathrm{~Hz}, 1 \mathrm{H}), 3.97(\mathrm{~s}, 3 \mathrm{H}), 2.78(\mathrm{~s}, 3 \mathrm{H}) ;{ }^{13} \mathrm{C} \mathrm{NMR}\left(100 \mathrm{MHz}, \mathrm{CDCl}_{3}\right) \delta$ 204.7, 167.5, 157.9, 134.8, 132.5, 114.9, 114.1, 63.2, 32.4; IR (ATR) 3091, 2957, 1942, 1631, 1592, 1336, 1297, 1224, 1100, $791 \mathrm{~cm}^{-1}$; HRMS (ESI) calcd for $\mathrm{C}_{9} \mathrm{H}_{10} \mathrm{NO}_{5}\left(\mathrm{M}+\mathrm{H}^{+}\right) 212.0559$, found 212.0556.

Analytical data for 137: $\mathrm{mp}=70-71{ }^{\circ} \mathrm{C} ;{ }^{1} \mathrm{H} \mathrm{NMR}\left(400 \mathrm{MHz}, \mathrm{CDCl}_{3}\right) \delta 11.62(\mathrm{~s}, 1 \mathrm{H}), 8.85(\mathrm{~s}$, 1H), $4.00(\mathrm{~s}, 3 \mathrm{H}), 2.63(\mathrm{~s}, 3 \mathrm{H}) ;{ }^{13} \mathrm{C} \mathrm{NMR}\left(100 \mathrm{MHz}, \mathrm{CDCl}_{3}\right) \delta 198.1,157.7,156.2,135.2,129.1$, 
126.5, 125.1, 64.4, 32.1; IR (ATR) 3210, 2958, 2155, 1790, 1713, 1587, 1530, 1125, 960, 665

$\mathrm{cm}^{-1}$; HRMS (ESI) calcd for $\mathrm{C}_{9} \mathrm{H}_{9} \mathrm{~N}_{2} \mathrm{O}_{7}\left(\mathrm{M}+\mathrm{H}^{+}\right)$257.0410, found 257.0398 .

Analytical data for 138: $\mathrm{mp}=94-95{ }^{\circ} \mathrm{C} ;{ }^{1} \mathrm{H}$ NMR $\left(400 \mathrm{MHz}, \mathrm{CDCl}_{3}\right) \delta 12.44(\mathrm{~s}, 1 \mathrm{H}), 8.20(\mathrm{~d}, J=$ $10.8 \mathrm{~Hz}, 1 \mathrm{H}), 6.57(\mathrm{~d}, J=9.6 \mathrm{~Hz}, 1 \mathrm{H}), 3.98(\mathrm{~s}, 3 \mathrm{H}), 2.61(\mathrm{~s}, 3 \mathrm{H}) ;{ }^{13} \mathrm{C} \mathrm{NMR}\left(100 \mathrm{MHz}, \mathrm{CDCl}_{3}\right) \delta$ 202.0, 164.0, 156.2, 130.4, 129.6, 115.7, 102.5, 65.5, 32.6; IR (ATR) 3008, 2970, 1738, 1442, 1366, 1217, 1229, $1109 \mathrm{~cm}^{-1}$; HRMS (ESI) calcd for $\mathrm{C}_{9} \mathrm{H}_{10} \mathrm{NO}_{5}\left(\mathrm{M}+\mathrm{H}^{+}\right) 212.0559$, found 212.0556.<smiles>COc1ccc([N+](=O)[O-])c(O)c1C(C)=O</smiles>

138

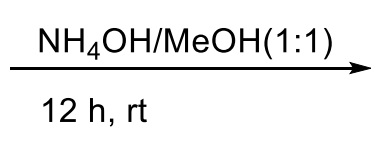

$12 \mathrm{~h}, \mathrm{rt}$

1)

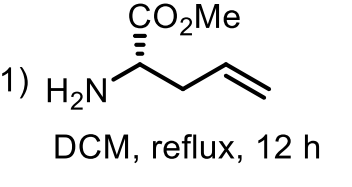

2) $\mathrm{NaBH}_{4}, \mathrm{MeOH}$

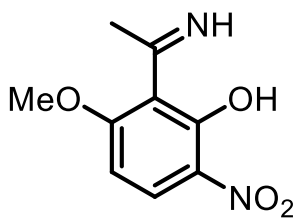

139

not isolated

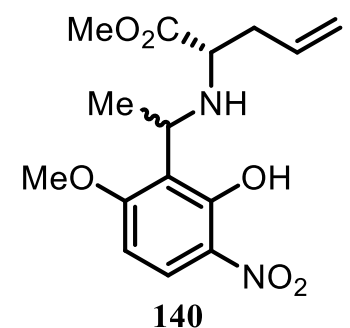

$78 \%$

A solution of $\mathrm{NH}_{4} \mathrm{OH}$ and $\mathrm{MeOH}(1: 1, \mathrm{v} / \mathrm{v})(20 \mathrm{~mL})$ was added dropwise to 138 (973 mg, $4.61 \mathrm{mmol}$ ) at ambient temperature. The resulting mixture was stirred for $12 \mathrm{~h}$ and the solvents were removed under reduced pressure to obtain yellow solid. This crude imine was dissolved in dichloromethane $(10 \mathrm{~mL})$, and $(\mathrm{S})$-2-amino-4-pentenoic acid methyl ester hydrochloride $(1.53 \mathrm{~g}$, $9.22 \mathrm{mmol}$ ) and triethylamine (466 mg, $4.61 \mathrm{mmol}$ ) were added. The mixture was stirred under reflux for $12 \mathrm{~h}$. Solvents were removed under reduced pressure and the crude product was dissolved in methanol $(20 \mathrm{~mL})$. To the stirred mixture at ambient temperature was added $\mathrm{NaBH}_{4}$ 
(261 mg, $6.91 \mathrm{mmol}$ ) in one portion. The resulting mixture was stirred for $2 \mathrm{~h}$ at ambient temperature. The solvent was removed under reduced pressure and the crude product was purified by chromatography (DCM: $\left.\mathrm{MeOH}: \mathrm{NH}_{4} \mathrm{OH}, 100: 2: 1\right)$ to afford 140 as a mixture of diastereomers (1.16 g, $3.58 \mathrm{mmol}, 78 \%$ overall) as yellow solid.

Analytical data for $\mathbf{1 4 0}$ as a mixture of diastereomers: $\mathrm{mp}=104-106{ }^{\circ} \mathrm{C} ;{ }^{1} \mathrm{H}$ NMR $(400 \mathrm{MHz}$, $\left.\mathrm{CDCl}_{3}\right) \delta 8.00(\mathrm{~d}, J=9.2 \mathrm{~Hz}, 1 \mathrm{H}), 7.96(\mathrm{~d}, J=9.6 \mathrm{~Hz}, 1 \mathrm{H}), 6.45(\mathrm{~d}, J=8.8 \mathrm{~Hz}, 1 \mathrm{H}), 6.42(\mathrm{~d}, J=$ $9.6 \mathrm{~Hz}, 1 \mathrm{H}), 5.73(\mathrm{~m}, 1 \mathrm{H}), 5.61(\mathrm{~m}, 1 \mathrm{H}), 5.13(\mathrm{~m}, 4 \mathrm{H}), 4.54(\mathrm{q}, J=7.2 \mathrm{~Hz}, 1 \mathrm{H}), 4.37$ (q, $J=7.2$ Hz, 1H), 3.91 (s, 3H), 3.85 (s, 3H), 3.75 (s, 3H), 3.49 (s, 3H), 3.35 (t, $J=6.4 \mathrm{~Hz}, 1 \mathrm{H}), 3.29(\mathrm{t}, J=$ $6.0 \mathrm{~Hz}, 1 \mathrm{H}), 2.44(\mathrm{~m}, 4 \mathrm{H}), 1.44(\mathrm{~d}, J=3.6 \mathrm{~Hz}, 3 \mathrm{H}), 1.42(\mathrm{~d}, J=4.0 \mathrm{~Hz}, 3 \mathrm{H}) ;{ }^{13} \mathrm{C}$ NMR $(151$ $\left.\mathrm{MHz}, \mathrm{CDCl}_{3}\right) \delta 173.8,173.7,163.0,162.0,155.2,154.9,133.0,131.9,131.2,129.7,126.5$, 126.0, 119.4, 118.4, 118.3, 115.7, 102.7, 101.6, 77.2, 77.0, 76.8, 58.8, 58.4, 56.1, 56.0, 52.1, 51.6, 50.1, 47.9, 37.4, 36.8, 20.4, 19.7; IR (ATR) 3305, 2953, 2229, 2171, 1739, 1599, 1498, 1279, 1241, 1094, $925 \mathrm{~cm}^{-1}$; HRMS (ESI) calcd for $\mathrm{C}_{15} \mathrm{H}_{21} \mathrm{~N}_{2} \mathrm{O}_{6}\left(\mathrm{M}+\mathrm{H}^{+}\right)$325.1400, found 325.1405

Analytical data for $\mathbf{1 4 0}$ (single isomer): $[\alpha]_{\mathrm{D}}^{21}=-110.3 \pm 0.1(c=0.1, \mathrm{MeOH}) ; \mathrm{mp}=94-95^{\circ} \mathrm{C} ;{ }^{1} \mathrm{H}$ NMR (400 MHz, CDCl $) \delta 7.97(\mathrm{~d}, J=9.6 \mathrm{~Hz}, 1 \mathrm{H}), 6.42(\mathrm{~d}, J=9.6 \mathrm{~Hz}, 1 \mathrm{H}), 5.62(\mathrm{~m}, 1 \mathrm{H}), 5.13$ (m, 2H), 4.37 (q, $J=7.2 \mathrm{~Hz}, 1 \mathrm{H}), 3.85(\mathrm{~s}, 3 \mathrm{H}), 3.75(\mathrm{~s}, 3 \mathrm{H}), 3.29(\mathrm{t}, J=6.0 \mathrm{~Hz}, 1 \mathrm{H}), 2.45(\mathrm{t}, J=$ 6.4 Hz, 2H), $1.43(\mathrm{~d}, J=6.4 \mathrm{~Hz}, 3 \mathrm{H}) ;{ }^{13} \mathrm{C} \mathrm{NMR}\left(151 \mathrm{MHz}, \mathrm{CDCl}_{3}\right) \delta 173.7,162.0,155.2,131.9$, 131.3, 126.6, 119.5, 115.8, 101.6, 77.2, 77.0, 76.8, 58.4, 56.0, 52.1, 50.2, 37.4, 20.4; IR (ATR) 3305, 2953, 2848, 2531, 2196, 1735, 1596, 1497, 1276, 1237, 1014, $806 \mathrm{~cm}^{-1}$; HRMS (ESI) calcd for $\mathrm{C}_{15} \mathrm{H}_{21} \mathrm{~N}_{2} \mathrm{O}_{6}\left(\mathrm{M}+\mathrm{H}^{+}\right)$325.1400, found 325.1405 


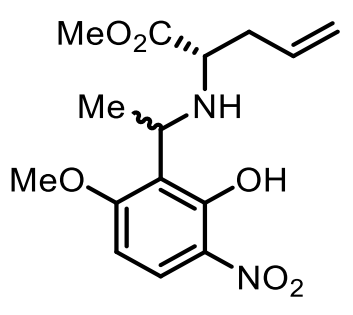

140

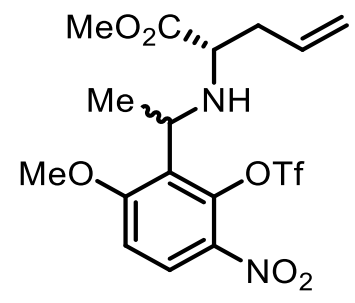

$142(\beta-\mathrm{Me} 53 \%)$

$143(\alpha-\mathrm{Me} 36 \%)$

To a stirred solution of $\mathbf{1 4 0}(1.028 \mathrm{~g}, 3.17 \mathrm{mmol})$ in DCM (32 mL) under nitrogen at ambient temperature was added pyridine $(627 \mathrm{mg}, 7.92 \mathrm{mmol})$. The resulting mixture was cooled to $0{ }^{\circ} \mathrm{C}$ and trifluoromethanesulfonic anhydride $(1.073 \mathrm{~g}, 3.80 \mathrm{mmol})$ was added dropwise. After stirring for $6 \mathrm{~h}$ at $0{ }^{\circ} \mathrm{C}$, the reaction was quenched with saturated $\mathrm{NH}_{4} \mathrm{Cl}$ solution $(50 \mathrm{~mL})$ and extracted with DCM $(3 \times 50 \mathrm{~mL})$. The organic phases were combined, washed with $5 \% \mathrm{CuSO}_{4}$ solution $(50 \mathrm{~mL})$, dried $\left(\mathrm{MgSO}_{4}\right)$ and filtered. The filtrate was evaporated under reduced pressure and the crude product was purified by chromatography (EtOAc/hexane/AcOH, 50:50:1) affording, in the order of elution, 142 (622 mg, $1.36 \mathrm{mmol}, 43 \%)$ as yellow oil and 143 (640 $\mathrm{mg}$, $1.40 \mathrm{mmol}, 44 \%$ ) as yellow solid.

Analytical data for 142: $[\alpha]_{\mathrm{D}}^{21}=-131.6 \pm 0.1(c=0.03, \mathrm{MeOH}) ;{ }^{1} \mathrm{H} \mathrm{NMR}\left(400 \mathrm{MHz}, \mathrm{CDCl}_{3}\right) \delta$ $7.96(\mathrm{~d}, J=6.4 \mathrm{~Hz}, 1 \mathrm{H}), 6.94(\mathrm{~d}, J=6.0 \mathrm{~Hz}, 1 \mathrm{H}), 5.72(\mathrm{~m}, 1 \mathrm{H}), 5.04(\mathrm{~m}, 2 \mathrm{H}), 4.21(\mathrm{q}, J=4.8 \mathrm{~Hz}$, 1H), $3.99(\mathrm{~s}, 3 \mathrm{H}), 3.30(\mathrm{~s}, 3 \mathrm{H}), 3.21(\mathrm{t}, J=4.8 \mathrm{~Hz}, 1 \mathrm{H}), 2.33(\mathrm{~m}, 2 \mathrm{H}), 1.51(\mathrm{~d}, J=4.8 \mathrm{~Hz}, 3 \mathrm{H})$; ${ }^{13} \mathrm{C}$ NMR $\left(150 \mathrm{MHz}, \mathrm{CDCl}_{3}\right) \delta 174.7,163.3,137.9,135.9,133.5,128.4,126.4,121.4,119.3$, 117.7, 117.2, 115.0, 110.1, 77.2, 77.0, 76.8, 60.1, 56.6, 51.3, 50.7, 38.2, 19.9; IR (ATR) 2954, 2162, 1737, 1598, 1586, $1215 \mathrm{~cm}^{-1}$; HRMS (ESI) calcd for $\mathrm{C}_{16} \mathrm{H}_{20} \mathrm{~F}_{3} \mathrm{~N}_{2} \mathrm{O}_{8} \mathrm{~S}\left(\mathrm{M}+\mathrm{H}^{+}\right)$457.0893, found 457.0910

Analytical data for 143: $[\alpha]_{\mathrm{D}}^{21}=27.9 \pm 0.1(c=0.04, \mathrm{MeOH}) ; \mathrm{mp}=68-69{ }^{\circ} \mathrm{C} ;{ }^{1} \mathrm{H} \mathrm{NMR}(400 \mathrm{MHz}$, $\left.\mathrm{CDCl}_{3}\right) \delta 8.04(\mathrm{~d}, J=6.0 \mathrm{~Hz}, 1 \mathrm{H}), 6.97(\mathrm{~d}, J=6.0 \mathrm{~Hz}, 1 \mathrm{H}), 5.51(\mathrm{~m}, 1 \mathrm{H}), 5.08(\mathrm{~m}, 2 \mathrm{H}), 4.34(\mathrm{q}$, $J=4.8 \mathrm{~Hz}, 1 \mathrm{H}), 3.98(\mathrm{~s}, 3 \mathrm{H}), 3.74(\mathrm{~s}, 3 \mathrm{H}), 3.01(\mathrm{dd}, J=6.0,3.2 \mathrm{~Hz}, 1 \mathrm{H}), 2.55(\mathrm{br} \mathrm{s}, 1 \mathrm{H}), 2.43(\mathrm{~m}$, 
1H), $2.29(\mathrm{~m}, 1 \mathrm{H}), 1.54(\mathrm{~d}, J=4.8 \mathrm{~Hz}, 3 \mathrm{H}) ;{ }^{13} \mathrm{C} \mathrm{NMR}\left(151 \mathrm{MHz}, \mathrm{CDCl}_{3}\right) \delta 174.0,162.8,138.6$, 136.4, 133.6, 128.6, 126.6, 121.5, 119.3, 118.5, 117.2, 115.1, 109.9, 58.7, 56.5, 51.9, 49.5, 37.4, 19.5; IR (ATR) 2953, 2229, 2031, 1740, 1531, 1348, $1216 \mathrm{~cm}^{-1}$; HRMS (ESI) calcd for $\mathrm{C}_{16} \mathrm{H}_{20} \mathrm{~F}_{3} \mathrm{~N}_{2} \mathrm{O}_{8} \mathrm{~S}\left(\mathrm{M}+\mathrm{H}^{+}\right) 457.0893$, found 457.0910
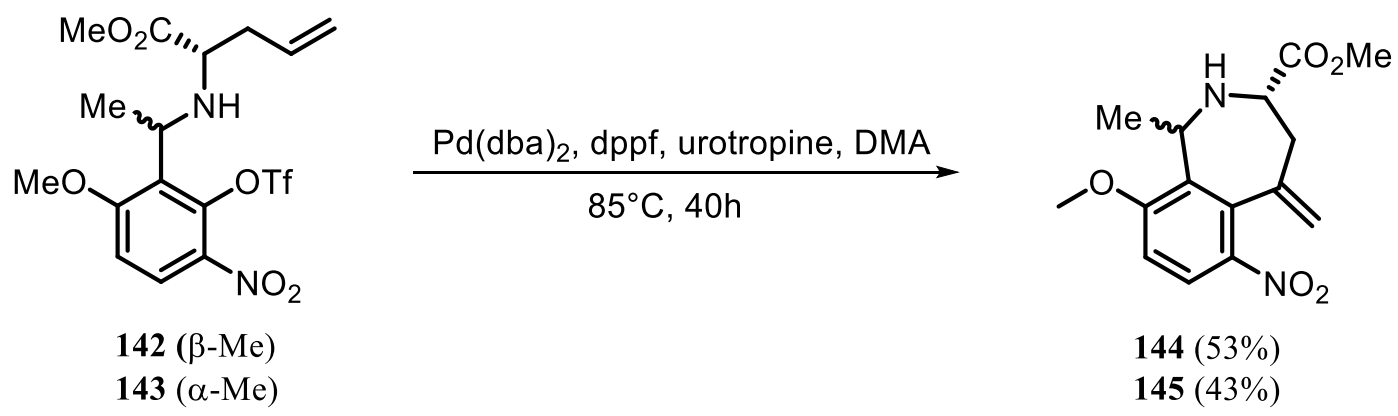

Urotropine (382 mg, $2.73 \mathrm{mmol}$ ), bis(diphenylphospino)ferrocene (76 mg, $0.14 \mathrm{mmol}$ ), bis(dibenzylideneacetone)palladium (39 $\mathrm{mg}, 0.07 \mathrm{mmol}$ ) and $N, N$-dimethylacetamide (DMA) $(10 \mathrm{~mL})$ were added in a $50-\mathrm{mL}$ round-bottomed flask. The mixture was stirred at ambient temperature for 5 minutes and a solution of $142(622 \mathrm{mg}, 1.36 \mathrm{mmol})$ in DMA $(3.6 \mathrm{~mL})$ was added under nitrogen. The resulting mixture was stirred at $90{ }^{\circ} \mathrm{C}$ for $48 \mathrm{~h}$, cooled to ambient temperature and filtered through a pad of silica gel. The filtrate was washed with water $(50 \mathrm{~mL})$, dried $\left(\mathrm{MgSO}_{4}\right)$, filtered and the solvents were removed under reduced pressure. Purification of the crude product by chromatography (EtOAc/hexanes, 4:6) gave 144 (220 mg, 0.72mmol, 53\%) as yellow solid.

Analytical data for 144: $[\alpha]_{\mathrm{D}}^{21}=-45.5 \pm 0.1(c=0.02, \mathrm{MeOH}) ; \mathrm{mp}=78-80{ }^{\circ} \mathrm{C},{ }^{1} \mathrm{H}$ NMR $(400$ $\left.\mathrm{MHz}, \mathrm{CDCl}_{3}\right) \delta 7.57(\mathrm{~d}, J=8.8 \mathrm{~Hz}, 1 \mathrm{H}), 6.76(\mathrm{~d}, J=9.2 \mathrm{~Hz}, 1 \mathrm{H}), 5.06(\mathrm{~m}, 4 \mathrm{H}), 4.09$ (dd, $J=11.2$, $3.2 \mathrm{~Hz}, 1 \mathrm{H}), 3.86(\mathrm{~s}, 3 \mathrm{H}), 3.73$ (s, 3H), 3.04 (dd, $J=12.8,3.2 \mathrm{~Hz}, 1 \mathrm{H}), 2.50$ (br s, 1H), 2.25 (br s, 1H), $1.37(\mathrm{~d}, J=7.2 \mathrm{~Hz}, 3 \mathrm{H}) ;{ }^{13} \mathrm{C} \mathrm{NMR}\left(151 \mathrm{MHz}, \mathrm{CDCl}_{3}\right) \delta 173.4,157.6,144.1,142.4,137.3$, 133.8, 123.5, 117.9, 108.7, 77.2, 77.0, 76.8, 56.7, 56.1, 52.2, 46.9, 41.1, 17.0; IR (ATR) 2970, 
2229, 1738, 1574, 1520, 1353, $1217 \mathrm{~cm}^{-1}$; HRMS (ESI) calcd for $\mathrm{C}_{15} \mathrm{H}_{19} \mathrm{~N}_{2} \mathrm{O}_{5}\left(\mathrm{M}+\mathrm{H}^{+}\right) 307.1294$, found 307.1292

Urotropine (393 mg, $2.80 \mathrm{mmol}$ ), bis(diphenylphospino) ferrocene (78 mg, $0.14 \mathrm{mmol}$ ), bis(dibenzylideneacetone)palladium (40 mg, $0.07 \mathrm{mmol})$ and $\mathrm{N}, \mathrm{N}$-dimethylacetamide (DMA)(5 $\mathrm{mL}$ ) were added in a $50 \mathrm{~mL}$ round-bottomed flask. The mixture was stirred at ambient temperature for 10 minutes and a solution of $143(640 \mathrm{mg}, 1.40 \mathrm{mmol})$ in DMA $(9 \mathrm{~mL})$ was added under nitrogen. The resulting mixture was stirred at $90{ }^{\circ} \mathrm{C}$ for $48 \mathrm{~h}$, cooled to ambient temperature and filtered through a pad of silica gel. The filtrate was washed with water $(50 \mathrm{~mL})$, dried $\left(\mathrm{MgSO}_{4}\right)$, filtered and the solvents were removed under reduced pressure. Purification of the crude product by chromatography (EtOAc/hexanes, 4:6) gave 145 (183 mg, $0.60 \mathrm{mmol}$, $43 \%$ ) as yellow oil.

Analytical data for 145: $[\alpha]_{\mathrm{D}}^{21}=11.6 \pm 0.1(c=0.02, \mathrm{MeOH}) ;{ }^{1} \mathrm{H} \mathrm{NMR}\left(400 \mathrm{MHz}, \mathrm{CDCl}_{3}\right) \delta 7.66$ $(\mathrm{d}, J=9.2 \mathrm{~Hz}, 1 \mathrm{H}), 6.81(\mathrm{~d}, J=9.2 \mathrm{~Hz}, 1 \mathrm{H}), 5.14(\mathrm{~s}, 1 \mathrm{H}), 4.92(\mathrm{~s}, 1 \mathrm{H}), 4.60(\mathrm{q}, J=6.4 \mathrm{~Hz}, 1 \mathrm{H})$, $3.86(\mathrm{~s}, 3 \mathrm{H}), 3.69(\mathrm{~s}, 3 \mathrm{H}), 3.53(\mathrm{dd}, J=11.2,6.4 \mathrm{~Hz}, 1 \mathrm{H}), 3.26(\mathrm{ddt}, J=14.0,6.0,2.0 \mathrm{~Hz}, 1 \mathrm{H})$, $2.70(\mathrm{dd}, J=13.6,11.2 \mathrm{~Hz}, 1 \mathrm{H}), 1.29(\mathrm{~d}, J=6.8 \mathrm{~Hz}, 3 \mathrm{H}) ;{ }^{13} \mathrm{C} \mathrm{NMR}\left(100 \mathrm{MHz}, \mathrm{CDCl}_{3}\right) \delta 174.0$, $159.2,143.3,140.7,133.7,132.1,123.8,118.3,108.9,77.3,77.0,76.7,55.9,54.6,53.1,52.1$, 41.4, 21.6; IR (ATR) 2971, 2205, 1737, 1712, 1518, 1219, $996 \mathrm{~cm}^{-1}$; HRMS (ESI) calcd for $\mathrm{C}_{15} \mathrm{H}_{19} \mathrm{~N}_{2} \mathrm{O}_{5}\left(\mathrm{M}+\mathrm{H}^{+}\right) 307.1294$, found 307.1291

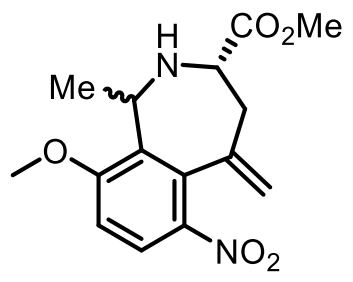

$144(\beta-\mathrm{Me})$ $145(\alpha-\mathrm{Me})$

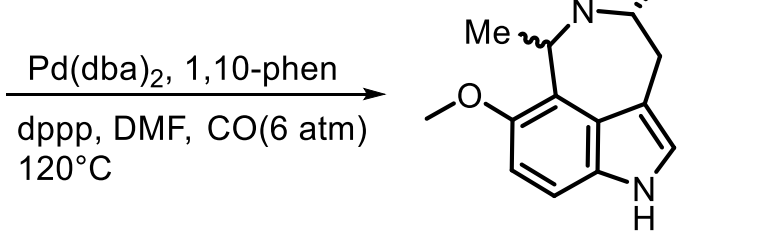

$146(44 \%)$ $147(43 \%)$ 
A solution of 144 (106 mg, $0.35 \mathrm{mmol})$, bis(dibenzylideneacetone)palladium (14 mg, $0.024 \mathrm{mmol}$ ), 1,3-bis(diphenylphosphino)propane (10 mg, $0.024 \mathrm{mmol})$, and 1,10phenanthroline ( $9 \mathrm{mg}, 0.048 \mathrm{mmol}$ ) in anhydrous $N, N$-dimethylformamide $(3.5 \mathrm{~mL})$, in an ACEGlass pressure tube fitted with a pressure head, was saturated with carbon monoxide ( 4 cycles to $6 \mathrm{~atm}$ of $\mathrm{CO})$. The reaction mixture was stirred under $\mathrm{CO}(6 \mathrm{~atm})$ at $120^{\circ} \mathrm{C}$ for $72 \mathrm{~h}$. The mixture was cooled to ambient temperature, filtered through a pad of silica gel and the filtrate was evaporated under reduced pressure. The resulting residue was purified by chromatography (hexanes/EtOAc, 1:1) to afford 146 (42 mg, $0.15 \mathrm{mmol}, 44 \%$ ) as yellow solid.

Analytical data for 146: $[\alpha]_{\mathrm{D}}^{21}=66.7 \pm 0.1(c=0.003, \mathrm{MeOH}) ; \mathrm{mp}=126-127^{\circ} \mathrm{C},{ }^{1} \mathrm{H}$ NMR $(400$ $\left.\mathrm{MHz}, \mathrm{CDCl}_{3}\right) \delta 8.05(\mathrm{~s}, 1 \mathrm{H}), 7.16(\mathrm{~d}, J=8.8 \mathrm{~Hz}, 1 \mathrm{H}), 7.00(\mathrm{~s}, 1 \mathrm{H}), 6.87$ (d, $\left.J=8.8 \mathrm{~Hz}, 1 \mathrm{H}\right), 4.99$ (q, $J=6.8 \mathrm{~Hz}, 1 \mathrm{H}), 4.17$ (dd, $J=12.0,2.8 \mathrm{~Hz}, 1 \mathrm{H}), 3.86$ (s, 3H), 3.80 (s, 3H), 3.55 (dd, $J=15.2$, $2.8 \mathrm{~Hz}, 1 \mathrm{H}), 3.01(\mathrm{~m}, 1 \mathrm{H}), 1.49(\mathrm{~d}, J=6.8 \mathrm{~Hz}, 3 \mathrm{H}) ;{ }^{13} \mathrm{C} \mathrm{NMR}\left(101 \mathrm{MHz}, \mathrm{CDCl}_{3}\right) \delta$ 175.1, 149.0, 132.6, 127.6, 124.9, 122.7, 112.5, 109.0, 108.5, 77.3, 77.0, 76.7, 57.1, 54.0, 52.3, 51.5, 34.6, 19.9; IR (ATR) 3650, 3003, 2003, 1739, 1439, 1366, 1231, $1216 \mathrm{~cm}^{-1}$; HRMS (ESI) calcd for $\mathrm{C}_{15} \mathrm{H}_{19} \mathrm{~N}_{2} \mathrm{O}_{3}\left(\mathrm{M}+\mathrm{H}^{+}\right) 275.1396$, found 275.1401.

A solution of 145 (194 mg, $0.63 \mathrm{mmol})$, bis(dibenzylideneacetone)palladium ( $25 \mathrm{mg}$, $0.044 \mathrm{mmol}), 1,3-$ bis(diphenylphosphino)propane (18 mg, $0.044 \mathrm{mmol})$, and 1,10phenanthroline (16 mg, $0.089 \mathrm{mmol})$ in anhydrous $N, N$-dimethylformamide $(6 \mathrm{~mL})$, in an ACEGlass pressure tube fitted with a pressure head, was saturated with carbon monoxide ( 4 cycles to $6 \mathrm{~atm}$ of $\mathrm{CO})$. The reaction mixture was stirred under $\mathrm{CO}(6 \mathrm{~atm})$ at $120^{\circ} \mathrm{C}$ for $72 \mathrm{~h}$. The mixture was cooled to ambient temperature, filtered through a pad of silica gel and the filtrate was evaporated under reduced pressure. The resulting residue was purified by chromatography (hexanes/EtOAc, 1:1) to afford 147 (75 $\mathrm{mg}, 0.27 \mathrm{mmol}, 43 \%$ ) as yellow solid. 
Analytical data for 147: $[\alpha]_{\mathrm{D}}^{21}=-8.3 \pm 0.1(c=0.012, \mathrm{MeOH}) ; \mathrm{mp}=141-143{ }^{\circ} \mathrm{C},{ }^{1} \mathrm{H}$ NMR $(400$ $\left.\mathrm{MHz}, \mathrm{CDCl}_{3}\right) \delta 7.96(\mathrm{br} \mathrm{s}, 1 \mathrm{H}), 7.17(\mathrm{~d}, J=8.4 \mathrm{~Hz}, 1 \mathrm{H}), 7.00(\mathrm{br} \mathrm{s}, 1 \mathrm{H}), 6.88(\mathrm{~d}, J=8.4 \mathrm{~Hz}, 1 \mathrm{H})$, $4.68(\mathrm{q}, J=6.4 \mathrm{~Hz}, 1 \mathrm{H}), 3.87(\mathrm{dd}, J=11.8,2.8 \mathrm{~Hz}, 1 \mathrm{H}), 3.84(\mathrm{~s}, 3 \mathrm{H}), 3.79$ (s, 3H), 3.37 (dd, $J=$ 15.2, $2.8 \mathrm{~Hz}, 1 \mathrm{H}), 3.17(\mathrm{~m}, 1 \mathrm{H}), 1.58(\mathrm{~d}, J=6.4 \mathrm{~Hz}, 3 \mathrm{H}) ;{ }^{13} \mathrm{C} \mathrm{NMR}\left(101 \mathrm{MHz}, \mathrm{CDCl}_{3}\right) \delta$ 175.1, $150.2,132.7,126.7,125.7,122.7,112.8,109.2,109.2,77.3,77.0,76.7,59.0,57.0,54.0,52.2$, 34.3, 23.7; IR (ATR) 3823, 3675, 3651, 1983, 1512, 1363, 1235; HRMS (ESI) calcd for $\mathrm{C}_{15} \mathrm{H}_{19} \mathrm{~N}_{2} \mathrm{O}_{3}\left(\mathrm{M}+\mathrm{H}^{+}\right)$275.1396, found 275.1400<smiles>CC(=O)c1c(O)cccc1OCc1ccccc1</smiles>

148

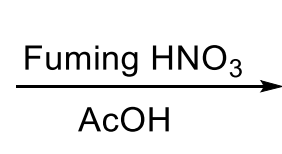
$\mathrm{AcOH}$

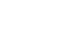<smiles>CC(=O)c1c(O)ccc([N+](=O)[O-])c1OCc1ccccc1</smiles>

$149(4 \%)$

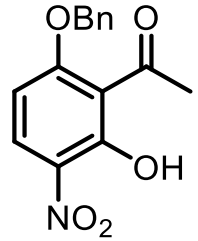

$150(45 \%)$

1-[2-Hydroxy-6-(phenylmethoxy)phenyl]ethanone (148) (1.54 g, $6.3 \mathrm{mmol})$ was dissolved in glacial acetic acid $(6.3 \mathrm{~mL})$ and fuming nitric acid $(0.6 \mathrm{~mL})$ was added dropwise. The reaction mixture was stirred in a round-bottomed flask equipped with a drying tube $\left(\mathrm{CaCl}_{2}\right)$ at room temperature for $40 \mathrm{~min}$, and then at $50{ }^{\circ} \mathrm{C}$ for $16 \mathrm{~h}$. The reaction mixture was poured into ice-water $(40 \mathrm{~mL})$ and extracted with EtOAc $(3 \times 40 \mathrm{~mL})$. The combined organic layers were dried $\left(\mathrm{MgSO}_{4}\right)$, filtered and solvents were removed under reduced pressure. The crude product was purified by chromatography (EtOAc/hexane, 2:8) affording, in the order of elution, 149 (96 $\mathrm{mg}, 0.33 \mathrm{mmol}, 5 \%)$ as a yellow solid and $\mathbf{1 5 0}(837 \mathrm{mg}, 2.91 \mathrm{mmol}, 46 \%)$ as yellow solid. Analytical data for 149: $\mathrm{mp}=103-104{ }^{\circ} \mathrm{C} ;{ }^{1} \mathrm{H}$ NMR $\left(400 \mathrm{MHz}, \mathrm{CDCl}_{3}\right) \delta 13.13(\mathrm{~s}, 1 \mathrm{H}), 8.10(\mathrm{~d}$, $J=12.0 \mathrm{~Hz}, 1 \mathrm{H}), 7.41(\mathrm{~m}, 5 \mathrm{H}), 6.83(\mathrm{~d}, J=8.0 \mathrm{~Hz}, 1 \mathrm{H}), 5.06(\mathrm{~s}, 2 \mathrm{H}), 2.60(\mathrm{~s}, 3 \mathrm{H}) ;{ }^{13} \mathrm{C} \mathrm{NMR}(100$ $\left.\mathrm{MHz}, \mathrm{CDCl}_{3}\right) \delta$ 205.0, 167.3, 156.4, 134.6, 132.5, 129.2, 128.8, 128.7, 115.9, 114.5, 79.4, 32.8; IR (ATR) 2933, 2189, 1631, 1593, 1456, 1365, 1053, 969, 831 $\mathrm{cm}^{-1}$; HRMS (ESI) calcd for $\mathrm{C}_{15} \mathrm{H}_{14} \mathrm{NO}_{5}\left(\mathrm{M}+\mathrm{H}^{+}\right)$288.0872, found 288.0867 
Analytical data for 150: $\mathrm{mp}=123-124{ }^{\circ} \mathrm{C} ;{ }^{1} \mathrm{H}$ NMR $\left(400 \mathrm{MHz}, \mathrm{CDCl}_{3}\right) \delta 12.38(\mathrm{~s}, 1 \mathrm{H}), 8.16(\mathrm{~d}$, $J=9.6 \mathrm{~Hz}, 1 \mathrm{H}), 7.39(\mathrm{~m}, 5 \mathrm{H}), 6.61(\mathrm{~d}, J=9.6 \mathrm{~Hz}, 1 \mathrm{H}), 5.23(\mathrm{~s}, 2 \mathrm{H}), 2.58(\mathrm{~s}, 3 \mathrm{H}) ;{ }^{13} \mathrm{C} \mathrm{NMR}(100$ $\left.\mathrm{MHz}, \mathrm{CDCl}_{3}\right) \delta 201.3,162.8,155.9,134.6,130.0,129.7,128.9,128.8,127.4,117.3,104.0,71.5$, 32.8; IR (ATR) 3071, 3039, 2628, 2193, 1623, 1588, 1367, 1319, 1246, 990, $777 \mathrm{~cm}^{-1}$; HRMS (ESI) calcd for $\mathrm{C}_{15} \mathrm{H}_{14} \mathrm{NO}_{5}\left(\mathrm{M}+\mathrm{H}^{+}\right) 288.0872$, found 288.0868

1. $\mathrm{NH}_{4} \mathrm{OH}: \mathrm{MeOH}(1: 1), \mathrm{rt}, 12 \mathrm{~h}$

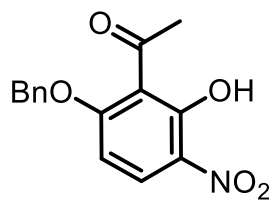

151

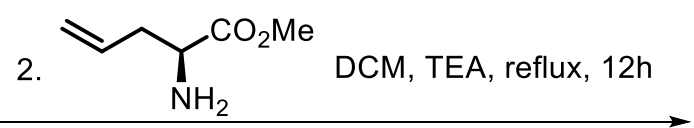

3. $\mathrm{NaBH}_{4}, \mathrm{MeOH}, \mathrm{rt}, 1 \mathrm{~h}$

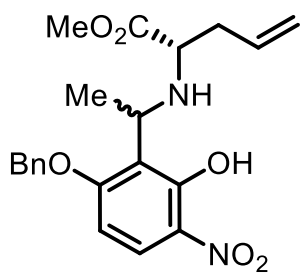

$152(\beta-\mathrm{Me} 45 \%)$

153 ( $\alpha$-Me 34\%)

A solution of $\mathrm{NH}_{4} \mathrm{OH}$ and $\mathrm{MeOH}(1: 1, \mathrm{v} / \mathrm{v})(20 \mathrm{~mL})$ was added dropwise to $150(1.675 \mathrm{~g}$, $5.83 \mathrm{mmol}$ ) at ambient temperature. The resulting mixture was stirred for $12 \mathrm{~h}$ and the solvents were removed under reduced pressure to obtain yellow solid. This crude imine was dissolved in dichloromethane (30 mL), and (S)-2-amino-4-pentenoic acid methyl ester hydrochloride (1.931 g, $11.66 \mathrm{mmol}$ ) and triethylamine $(590 \mathrm{mg}, 5.83 \mathrm{mmol})$ were added. The mixture was stirred under reflux for $12 \mathrm{~h}$. Solvents were removed under reduced pressure and the crude product was dissolved in methanol $(30 \mathrm{~mL})$. To the stirred mixture at ambient temperature was added $\mathrm{NaBH}_{4}$ (331 $\mathrm{mg}, 8.75 \mathrm{mmol}$ ) in one portion. The resulting mixture was stirred for $2 \mathrm{~h}$ at ambient temperature. The solvent was removed under reduced pressure and the crude product was purified by chromatography (EtOAc/hexane, 2:8) affording, in the order of elution, 152 (1.053 g, $2.63 \mathrm{mmol}, 45 \%$ ) and $\mathbf{1 5 3}$ (798 $\mathrm{mg}, 1.99 \mathrm{mmol}, 34 \%$ ) as yellow solids.

Analytical data for 152: $[\alpha]_{\mathrm{D}}^{21}=-2.1 \pm 0.1(c=0.05, \mathrm{MeOH}) ; \mathrm{mp}=110-112{ }^{\circ} \mathrm{C} ;{ }^{1} \mathrm{H}$ NMR $(400$ $\left.\mathrm{MHz}, \mathrm{CDCl}_{3}\right) \delta 7.98(\mathrm{~d}, J=9.6 \mathrm{~Hz}, 1 \mathrm{H}), 7.39(\mathrm{~m}, 5 \mathrm{H}), 6.55(\mathrm{~d}, J=9.2 \mathrm{~Hz}, 1 \mathrm{H}), 5.71(\mathrm{~m}, 1 \mathrm{H})$, 
$5.16(\mathrm{~m}, 2 \mathrm{H}), 5.07(\mathrm{~m}, 2 \mathrm{H}), 4.59(\mathrm{q}, J=6.8 \mathrm{~Hz}, 1 \mathrm{H}), 3.47(\mathrm{~s}, 3 \mathrm{H}), 3.37(\mathrm{t}, J=6.4 \mathrm{~Hz}, 1 \mathrm{H}), 2.42(\mathrm{t}$, $J=6.8 \mathrm{~Hz}, 2 \mathrm{H}), 1.44(\mathrm{~d}, J=6.8 \mathrm{~Hz}, 3 \mathrm{H}) ;{ }^{13} \mathrm{C} \mathrm{NMR}\left(100 \mathrm{MHz}, \mathrm{CDCl}_{3}\right) \delta 173.8,162.2,155.1$, $135.5,132.9,129.7,128.9,128.8,128.5,127.5,127.4,126.0,118.7,118.4,104.0,71.0,58.9$, 51.6, 48.0, 36.8, 19.8.; IR (ATR) 3649, 2952, 2033, 1737, 1592, 1435, 1275, $1238 \mathrm{~cm}^{-1}$; HRMS (ESI) calcd for $\mathrm{C}_{21} \mathrm{H}_{25} \mathrm{~N}_{2} \mathrm{O}_{6}\left(\mathrm{M}+\mathrm{H}^{+}\right) 401.1713$, found 401.1717

Analytical data for 153: $[\alpha]_{\mathrm{D}}^{21}=-21.6 \pm 0.1(c=0.05, \mathrm{MeOH}) ; \mathrm{mp}=109-110{ }^{\circ} \mathrm{C} ;{ }^{1} \mathrm{H} \mathrm{NMR}(400$ $\left.\mathrm{MHz}, \mathrm{CDCl}_{3}\right) \delta 7.95(\mathrm{~d}, J=9.6 \mathrm{~Hz}, 1 \mathrm{H}), 7.38(\mathrm{~m}, 5 \mathrm{H}), 6.48(\mathrm{~d}, J=9.6 \mathrm{~Hz}, 1 \mathrm{H}), 5.62(\mathrm{~m}, 1 \mathrm{H})$, $5.15(\mathrm{~m}, 4 \mathrm{H}), 4.49$ (q, $J=6.8 \mathrm{~Hz}, 1 \mathrm{H}), 3.69(\mathrm{~s}, 3 \mathrm{H}), 3.32(\mathrm{t}, J=6.4 \mathrm{~Hz}, 1 \mathrm{H}), 2.45(\mathrm{t}, J=6.0 \mathrm{~Hz}$, 2H), $1.48(\mathrm{~d}, J=6.4 \mathrm{~Hz}, 3 \mathrm{H}) ;{ }^{13} \mathrm{C} \mathrm{NMR}\left(100 \mathrm{MHz}, \mathrm{CDCl}_{3}\right) \delta 173.7,161.0,155.3,135.7,131.8$, $128.9,128.8,128.4,127.4,127.0,126.5,119.6,116.1,110.0,102.9,70.6,58.5,52.1,50.2,37.4$, 20.4; IR (ATR) 3650, 3305, 2953, 2173, 1910, 1736, 1597, $1276 \mathrm{~cm}^{-1}$; HRMS (ESI) calcd for $\mathrm{C}_{21} \mathrm{H}_{25} \mathrm{~N}_{2} \mathrm{O}_{6}\left(\mathrm{M}+\mathrm{H}^{+}\right) 401.1713$, found 401.1718

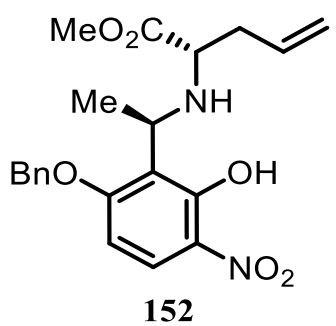

152

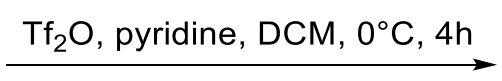

To a stirred solution of 152 (1.053 g, $2.63 \mathrm{mmol})$ in DCM (26 mL) under nitrogen at ambient temperature was added pyridine $(520 \mathrm{mg}, 6.58 \mathrm{mmol})$. The resulting mixture was cooled to $0{ }^{\circ} \mathrm{C}$ and trifluoromethanesulfonic anhydride $(890 \mathrm{mg}, 3.16 \mathrm{mmol})$ was added dropwise. After stirring for $4 \mathrm{~h}$ at $0{ }^{\circ} \mathrm{C}$, the reaction was quenched with saturated $\mathrm{NH}_{4} \mathrm{Cl}$ solution $(25 \mathrm{~mL})$ and extracted with DCM $(3 \times 50 \mathrm{~mL})$. The organic phases were combined, washed with $5 \% \mathrm{CuSO}_{4}$ solution $(50 \mathrm{~mL})$, dried $\left(\mathrm{MgSO}_{4}\right)$ and filtered. The filtrate was evaporated under reduced 
pressure and the crude product was purified by chromatography (EtOAc/hexane, 2:8) affording $154(1.223 \mathrm{~g}, 2.30 \mathrm{mmol}, 87 \%)$ as yellow oil.

Analytical data for 154: $[\alpha]_{\mathrm{D}}^{21}=75.8 \pm 0.1(c=0.03, \mathrm{MeOH}) ;{ }^{1} \mathrm{H}$ NMR $\left(400 \mathrm{MHz}, \mathrm{CDCl}_{3}\right) \delta 7.98$ (d, $J=10.0 \mathrm{~Hz}, 1 \mathrm{H}), 7.48(\mathrm{~m}, 5 \mathrm{H}), 7.03(\mathrm{~d}, J=9.2 \mathrm{~Hz}, 1 \mathrm{H}), 5.68(\mathrm{~m}, 1 \mathrm{H}), 5.22(\mathrm{~s}, 2 \mathrm{H}), 5.02(\mathrm{~m}$, $2 \mathrm{H}), 4.24(\mathrm{q}, J=7.2 \mathrm{~Hz}, 1 \mathrm{H}), 3.34(\mathrm{~s}, 3 \mathrm{H}), 3.25(\mathrm{t}, J=6.4 \mathrm{~Hz}, 1 \mathrm{H}), 2.83(\mathrm{br} \mathrm{s}, 1 \mathrm{H}), 2.33(\mathrm{t}, J=6.4$ $\mathrm{Hz}, 2 \mathrm{H}), 1.51(\mathrm{~d}, J=6.8 \mathrm{~Hz}, 3 \mathrm{H}) ;{ }^{13} \mathrm{C} \mathrm{NMR}\left(101 \mathrm{MHz}, \mathrm{CDCl}_{3}\right) \delta 174.8,162.5,138.0,136.1$, 134.5, 133.2, 129.0, 129.0, 128.6, 128.2, 126.4, 123.0, 119.9, 117.9, 116.7, 113.5, 111.0, 77.3, 77.0, 76.7, 72.1, 60.1, 51.4, 50.7, 38.2, 20.1; IR (ATR) 3464, 3004, 2949, 1737, 1433, 1365, $1227 \mathrm{~cm}^{-1}$; HRMS (ESI) calcd for $\mathrm{C}_{22} \mathrm{H}_{24} \mathrm{~F}_{3} \mathrm{~N}_{2} \mathrm{O}_{8} \mathrm{~S}\left(\mathrm{M}+\mathrm{H}^{+}\right) 533.1206$, found 533.1230<smiles>C=CC[C@@H](N[C@@H](C(C)=O)c1c(O)ccc([N+](=O)[O-])c1O)C(C)=O</smiles>

153

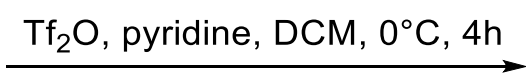

To a stirred solution of $\mathbf{1 5 3}$ (798 $\mathrm{mg}, 1.99 \mathrm{mmol})$ in DCM $(20 \mathrm{~mL})$ under nitrogen at ambient temperature was added pyridine $(394 \mathrm{mg}, 4.98 \mathrm{mmol})$. The resulting mixture was cooled to $0{ }^{\circ} \mathrm{C}$ and trifluoromethanesulfonic anhydride $(675 \mathrm{mg}, 2.39 \mathrm{mmol})$ was added dropwise. After stirring for $4 \mathrm{~h}$ at $0{ }^{\circ} \mathrm{C}$, the reaction was quenched with saturated $\mathrm{NH}_{4} \mathrm{Cl}$ solution $(25 \mathrm{~mL})$ and extracted with DCM $(3 \times 50 \mathrm{~mL})$. The organic phases were combined, washed with $5 \% \mathrm{CuSO}_{4}$ solution $(50 \mathrm{~mL})$, dried $\left(\mathrm{MgSO}_{4}\right)$ and filtered. The filtrate was evaporated under reduced pressure and the crude product was purified by chromatography (EtOAc/hexanes, 2:8) affording 155 (918 $\mathrm{mg}, 1.72 \mathrm{mmol}, 87 \%)$ as yellow oil. 
Analytical data for 155: $[\alpha]_{\mathrm{D}}^{21}=-2.7 \pm 0.1(c=0.04, \mathrm{MeOH}) ;{ }^{1} \mathrm{H} \mathrm{NMR}\left(400 \mathrm{MHz}, \mathrm{CDCl}_{3}\right) \delta 8.02$ $(\mathrm{d}, J=9.2 \mathrm{~Hz}, 1 \mathrm{H}), 7.43(\mathrm{~m}, 5 \mathrm{H}), 7.05(\mathrm{~d}, J=10.4 \mathrm{~Hz}, 1 \mathrm{H}), 5.47(\mathrm{~m}, 1 \mathrm{H}), 5.21(\mathrm{~m}, 2 \mathrm{H}), 4.96(\mathrm{~m}$, 2H), $4.32(\mathrm{q}, J=6.8 \mathrm{~Hz}, 1 \mathrm{H}), 3.70(\mathrm{~s}, 3 \mathrm{H}), 3.05(\mathrm{dd}, J=8.4,5.6 \mathrm{~Hz}, 1 \mathrm{H}), 2.38(\mathrm{~m}, 1 \mathrm{H}), 2.24(\mathrm{~m}$, 1H), $1.56(\mathrm{~d}, J=8.0 \mathrm{~Hz}, 3 \mathrm{H}) ;{ }^{13} \mathrm{C} \mathrm{NMR}\left(101 \mathrm{MHz}, \mathrm{CDCl}_{3}\right) \delta 173.9,161.9,138.6,136.4,134.2$, 133.3, 129.0, 129.0, 128.7, 127.6, 126.6, 123.0, 119.9, 118.6, 116.7, 113.5, 111.1, 71.8, 58.9, 51.9, 49.4, 37.4, 19.6; IR (ATR) 3467, 3016, 2971, 2952, 1740, 1365, 1228, $1029 \mathrm{~cm}^{-1}$; HRMS (ESI) calcd for $\mathrm{C}_{22} \mathrm{H}_{24} \mathrm{~F}_{3} \mathrm{~N}_{2} \mathrm{O}_{8} \mathrm{~S}\left(\mathrm{M}+\mathrm{H}^{+}\right)$533.1206, found 533.1234

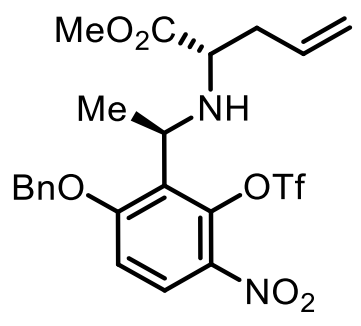

154

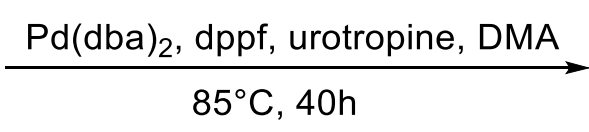

$85^{\circ} \mathrm{C}, 40 \mathrm{~h}$

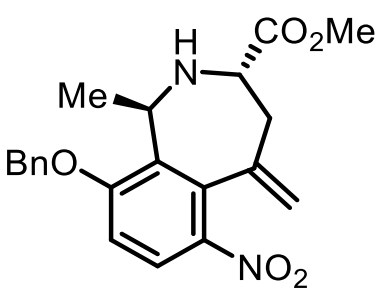

$158(52 \%)$

Urotropine (581 mg, $4.14 \mathrm{mmol}$ ), bis(diphenylphospino) ferrocene (115 mg, $0.21 \mathrm{mmol}$ ), bis(dibenzylideneacetone)palladium $(60 \mathrm{mg}, 0.10 \mathrm{mmol})$ and $N, N$-dimethylacetamide (DMA) (5 $\mathrm{mL}$ ) were added in a 50-mL round-bottomed flask. The mixture was stirred at ambient temperature for 10 minutes and a solution of 154 (1.103 g, $2.07 \mathrm{mmol})$ in DMA (15 mL) was added under nitrogen. The resulting mixture was stirred at $90^{\circ} \mathrm{C}$ for $48 \mathrm{~h}$, cooled to ambient temperature and filtered through a pad of silica gel. The filtrate was washed with brine $(50 \mathrm{~mL})$, dried $\left(\mathrm{MgSO}_{4}\right)$, filtered and the solvents were removed under reduced pressure. Purification of the crude product by chromatography (EtOAc/hexanes, 4:6) gave 158 (414 mg, $1.08 \mathrm{mmol}$, $52 \%)$ as yellow oil.

Analytical data for 158: $[\alpha]_{\mathrm{D}}^{21}=-235.3 \pm 0.1(c=0.007, \mathrm{MeOH}) ;{ }^{1} \mathrm{H} \mathrm{NMR}\left(400 \mathrm{MHz}, \mathrm{CDCl}_{3}\right) \delta$ $7.58(\mathrm{~d}, J=8.8 \mathrm{~Hz}, 1 \mathrm{H}), 7.37(\mathrm{~m}, 5 \mathrm{H}), 6.84(\mathrm{~d}, J=9.2 \mathrm{~Hz}, 1 \mathrm{H}), 5.18(\mathrm{~m}, 4 \mathrm{H}), 4.96(\mathrm{~s}, 1 \mathrm{H}), 4.12$ 
(dd, $J=11.2,2.8 \mathrm{~Hz}, 1 \mathrm{H}), 3.76$ (s, 3H), 3.09 (dd, $J=12.4,3.2 \mathrm{~Hz}, 1 \mathrm{H}$ ), 2.54 (br s, 1H), 2.08 (br s, 1H), $1.42(\mathrm{~d}, J=7.2 \mathrm{~Hz}, 3 \mathrm{H}) ;{ }^{13} \mathrm{C} \mathrm{NMR}\left(101 \mathrm{MHz}, \mathrm{CDCl}_{3}\right) \delta 173.3,156.6,144.3,142.3,139.9$, $137.4,135.8,134.2,128.7,128.3,127.1,123.5,118.0,110.1,77.3,77.0,76.7,70.8,56.6,52.2$, 47.2, 41.0, 17.1; IR (ATR) 3462, 3015, 2971, 2946, 1738, 1365, $1217 \mathrm{~cm}^{-1}$; HRMS (ESI) calcd for $\mathrm{C}_{21} \mathrm{H}_{23} \mathrm{~N}_{2} \mathrm{O}_{5}\left(\mathrm{M}+\mathrm{H}^{+}\right)$383.1607, found 383.1617

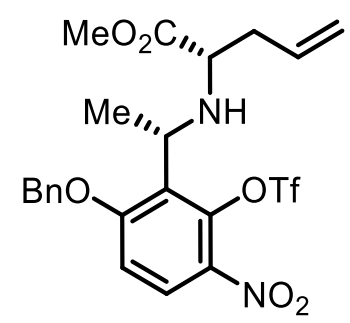

155

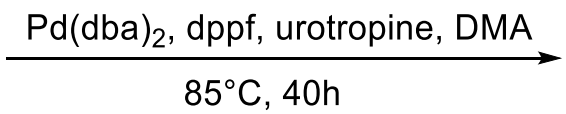

Urotropine (483 mg, $3.45 \mathrm{mmol}$ ), bis(diphenylphospino) ferrocene (96 mg, $0.17 \mathrm{mmol}$ ), $\mathrm{mL}$ ) were added in a 50-mL round-bottomed flask. The mixture was stirred at ambient temperature for 10 minutes and a solution of 155 (918 $\mathrm{mg}, 1.72 \mathrm{mmol})$ in DMA (12 mL) was added under nitrogen. The resulting mixture was stirred at $90{ }^{\circ} \mathrm{C}$ for $48 \mathrm{~h}$, cooled to ambient temperature and filtered through a pad of silica gel. The filtrate was washed with brine $(50 \mathrm{~mL})$, dried $\left(\mathrm{MgSO}_{4}\right)$, filtered and the solvents were removed under reduced pressure. Purification of the crude product by chromatography (EtOAc/hexanes, 4:6) gave 159 (303 mg, $0.79 \mathrm{mmol}$, $46 \%)$ as yellow oil.

Analytical data for 159: $[\alpha]_{\mathrm{D}}^{21}=-14.5 \pm 0.1(c=0.014, \mathrm{MeOH}) ;{ }^{1} \mathrm{H} \mathrm{NMR}\left(400 \mathrm{MHz}, \mathrm{CDCl}_{3}\right) \delta$ $7.69(\mathrm{~d}, J=9.2 \mathrm{~Hz}, 1 \mathrm{H}), 7.37$ (m, 5H), $6.90(\mathrm{~d}, J=9.2 \mathrm{~Hz}, 1 \mathrm{H}), 5.15(\mathrm{~m}, 3 \mathrm{H}), 4.98(\mathrm{~s}, 1 \mathrm{H}), 4.77$ (q, $J=6.4 \mathrm{~Hz}, 1 \mathrm{H}), 3.74(\mathrm{~s}, 3 \mathrm{H}), 3.60(\mathrm{dd}, J=11.2,6.4 \mathrm{~Hz}, 1 \mathrm{H}), 3.32(\mathrm{dd}, J=14.0,6.4 \mathrm{~Hz}, 1 \mathrm{H})$, $2.75(\mathrm{dd}, J=13.8,11.6 \mathrm{~Hz}, 1 \mathrm{H}), 1.64(\mathrm{br} \mathrm{s}, 1 \mathrm{H}), 1.38(\mathrm{~d}, J=6.4 \mathrm{~Hz}, 3 \mathrm{H}) ;{ }^{13} \mathrm{C} \mathrm{NMR}(101 \mathrm{MHz}$, $\left.\mathrm{CDCl}_{3}\right) \delta 174.1,158.2,143.6,140.7,135.6,133.9,132.5,128.7,128.3,126.9,123.9,118.5$, 
110.1, 77.3, 77.0, 76.7, 70.5, 54.7, 53.3, 52.2, 41.5, 21.8; IR (ATR) 3464, 3349, 3005, 2971, 1738, 1519, 1352, $1217 \mathrm{~cm}^{-1}$; HRMS (ESI) calcd for $\mathrm{C}_{21} \mathrm{H}_{23} \mathrm{~N}_{2} \mathrm{O}_{5}\left(\mathrm{M}+\mathrm{H}^{+}\right)$383.1607, found 383.1615<smiles>C=C1C[C@@H](C(C)=O)NC(C)c2c(OC(C)=O)ccc([N+](=O)[O-])c21</smiles>

158

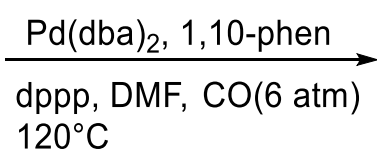
$120^{\circ} \mathrm{C}$

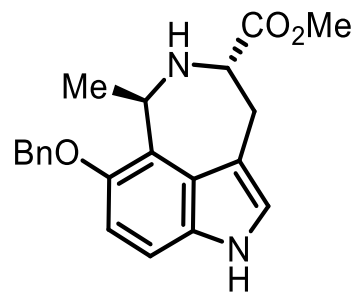

$160(73 \%)$

A solution of 158 (75 mg, $0.196 \mathrm{mmol})$, bis(dibenzylideneacetone)palladium ( $8 \mathrm{mg}$, $0.014 \mathrm{mmol}), 1,3$-bis(diphenylphosphino)propane (6 mg, $0.014 \mathrm{mmol})$, and 1,10-phenanthroline ( $5 \mathrm{mg}, 0.027 \mathrm{mmol}$ ) in anhydrous $N, N$-dimethylformamide $(2 \mathrm{~mL})$, in an ACE-Glass pressure tube fitted with a pressure head, was saturated with carbon monoxide (4 cycles to 6 atm of CO). The reaction mixture was stirred under $\mathrm{CO}(6 \mathrm{~atm})$ at $120^{\circ} \mathrm{C}$ for $72 \mathrm{~h}$. The mixture was cooled to ambient temperature, filtered through a pad of silica gel and the filtrate was evaporated under reduced pressure. The resulting residue was purified by chromatography (hexanes/EtOAc, 6:4) to afford 160 (50 mg, $0.143 \mathrm{mmol}, 73 \%)$ as white solid.

Analytical data for 160: $[\alpha]_{\mathrm{D}}^{21}=+16.7 \pm 0.1(c=0.012, \mathrm{MeOH}) ; \mathrm{mp}=163-164{ }^{\circ} \mathrm{C},{ }^{1} \mathrm{H}$ NMR $(400$ $\left.\mathrm{MHz}, \mathrm{CDCl}_{3}\right) \delta 8.19$ (br s, 1H), $7.39(\mathrm{~m}, 5 \mathrm{H}), 7.14(\mathrm{~d}, J=9.2 \mathrm{~Hz}, 1 \mathrm{H}), 6.98$ (br s, 1H), 6.91 (d, $J=8.8 \mathrm{~Hz}, 1 \mathrm{H}), 5.12(\mathrm{~m}, 3 \mathrm{H}), 4.20(\mathrm{dd}, J=12.2,2.8 \mathrm{~Hz}, 1 \mathrm{H}), 3.81(\mathrm{~s}, 3 \mathrm{H}), 3.56(\mathrm{dd}, J=15.6,2.4$ $\mathrm{Hz}, 1 \mathrm{H}), 3.03(\mathrm{ddd}, J=15.4,12.4,1.6 \mathrm{~Hz}, 1 \mathrm{H}), 2.32(\mathrm{br} \mathrm{s}, 2 \mathrm{H}), 1.55(\mathrm{~d}, J=6.8 \mathrm{~Hz}, 3 \mathrm{H}) ;{ }^{13} \mathrm{C}$ NMR $\left(101 \mathrm{MHz} \mathrm{CDCl}_{3}\right) \delta 175.0,148.0,138.1,132.8,128.4,128.1,127.6,127.6,127.2,127.0$, $124.9,122.8,112.5,109.9,109.2,77.3,77.0,76.7,71.8,54.0,52.3,51.6,34.5,20.1$; IR (ATR) $3823,3675,3651,1983,1512,1363,1235$; HRMS (ESI) calcd for $\mathrm{C}_{21} \mathrm{H}_{23} \mathrm{~N}_{2} \mathrm{O}_{3}\left(\mathrm{M}+\mathrm{H}^{+}\right)$ 351.1709 , found 351.1716 


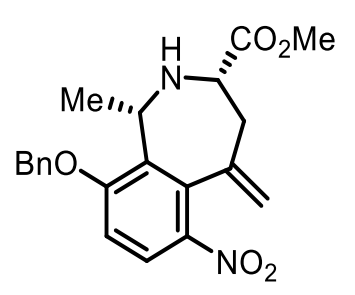

159

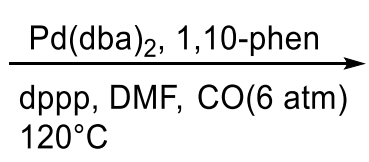

$120^{\circ} \mathrm{C}$

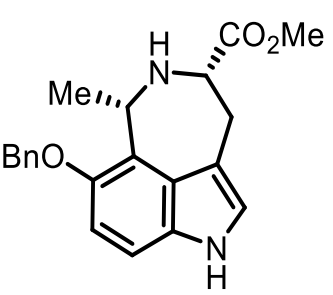

$161(59 \%)$

A solution of 159 (120 mg, $0.314 \mathrm{mmol})$, bis(dibenzylideneacetone)palladium (13 mg, $0.022 \mathrm{mmol}$ ), 1,3-bis(diphenylphosphino)propane (9 mg, $0.022 \mathrm{mmol}$ ), and 1,10-phenanthroline (8 mg, $0.044 \mathrm{mmol})$ in anhydrous $N, N$-dimethylformamide $(3.1 \mathrm{~mL})$, in an ACE-Glass pressure tube fitted with a pressure head, was saturated with carbon monoxide ( 4 cycles to 6 atm of CO). The reaction mixture was stirred under $\mathrm{CO}(6 \mathrm{~atm})$ at $120^{\circ} \mathrm{C}$ for $72 \mathrm{~h}$. The mixture was cooled to ambient temperature, filtered through a pad of silica gel and the filtrate was evaporated under reduced pressure. The resulting residue was purified by chromatography (hexanes/EtOAc, 6:4) to afford 161 (65 mg, $0.185 \mathrm{mmol}, 59 \%)$ as white solid.

Analytical data for 161: $[\alpha]_{\mathrm{D}}^{21}=-25.0 \pm 0.1(c=0.008, \mathrm{MeOH}) ; \mathrm{mp}=151-152{ }^{\circ} \mathrm{C} ;{ }^{1} \mathrm{H}$ NMR $(400$ $\left.\mathrm{MHz}, \mathrm{CDCl}_{3}\right) \delta 7.92$ (br s, 1H), $7.34(\mathrm{~m}, 5 \mathrm{H}), 7.16(\mathrm{~d}, J=8.4 \mathrm{~Hz}, 1 \mathrm{H}), 7.02$ (br s, 1H), 6.94 (d, $J=8.8 \mathrm{~Hz}, 1 \mathrm{H}), 5.09(\mathrm{dd}, J=16.4,12.0 \mathrm{~Hz}, 2 \mathrm{H}), 4.78(\mathrm{q}, J=6.4 \mathrm{~Hz}, 1 \mathrm{H}), 3.89(\mathrm{dd}, J=12.0,2.8$ Hz, 1H), 3.79 (s, 3H), 3.39 (dd, $J=15.2,2.8 \mathrm{~Hz}, 1 \mathrm{H}), 3.21$ (ddd, $J=15.4,11.6,1.6 \mathrm{~Hz}, 1 \mathrm{H}), 1.62$ $(\mathrm{d}, J=6.4 \mathrm{~Hz}, 3 \mathrm{H}) ;{ }^{13} \mathrm{C} \mathrm{NMR}\left(101 \mathrm{MHz}, \mathrm{CDCl}_{3}\right) \delta 175.0,149.2,138.0,132.9,128.4,127.6$, $127.4,127.2,125.8,122.7,113.0,110.7,109.3,77.3,77.0,76.7,72.1,59.0,53.9,52.2,34.1$, 23.9; IR (ATR) 3823, 3675, 3651, 1983, 1512, 1363, 1235; HRMS (ESI) calcd for $\mathrm{C}_{21} \mathrm{H}_{23} \mathrm{~N}_{2} \mathrm{O}_{3}$ $\left(\mathrm{M}+\mathrm{H}^{+}\right)$351.1709, found 351.1699 


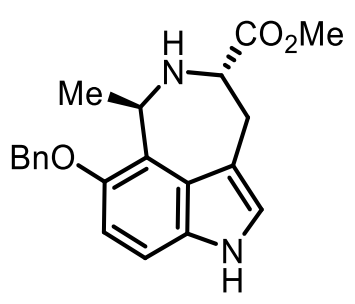

162

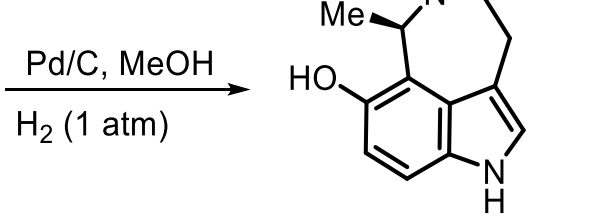

$164(83 \%)$

To a solution of $\mathbf{1 6 2}(50 \mathrm{mg}, 0.14 \mathrm{mmol})$ in methanol in an ACE-Glass pressure tube was added $\mathrm{Pd} / \mathrm{C}(10 \%)(7 \mathrm{mg}, 0.007 \mathrm{mmol})$. The resulting mixture was saturated with hydrogen gas (3 cycles to $2.7 \mathrm{~atm}$ ) and stirred at $60^{\circ} \mathrm{C}$ for $12 \mathrm{~h}$. The reaction mixture was filtered through celite and the filtrate obtained was concentrated under reduced pressure. Purification of the crude product using $\mathrm{MeOH} / \mathrm{CHCl}_{3}(1: 4)$ afforded $164(30 \mathrm{mg}, 0.12 \mathrm{mmol}, 83 \%)$ as an amorphous white powder.

Analytical data for 164: $[\alpha]_{\mathrm{D}}^{21}=-20.0 \pm 0.1(c=0.005, \mathrm{MeOH}) ; \mathrm{mp}=168-170{ }^{\circ} \mathrm{C}$ (lit: $183-185$

$\left.{ }^{\circ} \mathrm{C}\right){ }^{1} \mathrm{H}$ NMR (400 MHz, DMSO-D 6$) \delta 10.54$ (br s, 1H), 8.44 (s, 1H), $7.02(\mathrm{~s}, 1 \mathrm{H}), 6.98(\mathrm{~d}, J=8.4$ $\mathrm{Hz}, 1 \mathrm{H}), 6.62(\mathrm{~d}, J=8.4 \mathrm{~Hz}, 1 \mathrm{H}), 4.70(\mathrm{q}, J=6.8 \mathrm{~Hz}, 1 \mathrm{H}), 3.95(\mathrm{~d}, J=10.8 \mathrm{~Hz}, 1 \mathrm{H}), 3.68(\mathrm{~s}, 3 \mathrm{H})$, $3.32(\mathrm{~d}, J=14.8 \mathrm{~Hz}, 1 \mathrm{H}), 2.87(\mathrm{dd}, J=14.4,11.6 \mathrm{~Hz}, 1 \mathrm{H}), 1.34(\mathrm{~d}, J=6.8 \mathrm{~Hz}, 3 \mathrm{H}) ;{ }^{13} \mathrm{C} \mathrm{NMR}$ $\left(101 \mathrm{MHz}, \mathrm{CDCl}_{3}\right) \delta 175.0,144.4,132.4,125.1,125.0,122.4,112.6,112.2,109.3,54.0,52.3$, 51.5, 34.5, 19.5; IR (ATR) 3698, 3671, 3622, 2111, 1519, 1356, 1245; HRMS (ESI) calcd for $\mathrm{C}_{14} \mathrm{H}_{17} \mathrm{~N}_{2} \mathrm{O}_{3}\left(\mathrm{M}+\mathrm{H}^{+}\right)$261.1239, found 261.1237<smiles>CC(=O)[C@@H]1Cc2c[nH]c3ccc(OCc4ccccc4)c(c23)[C@H](C)N1</smiles>

163

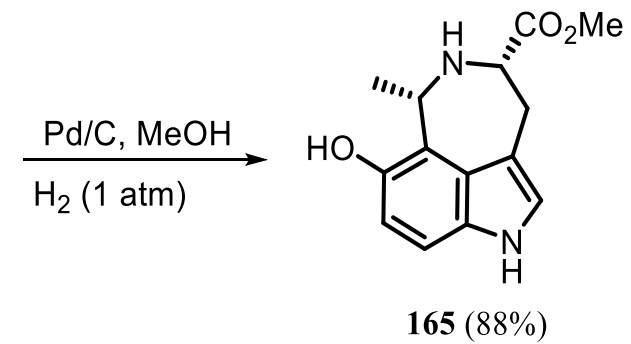

To a solution of 163 (46 mg, $0.13 \mathrm{mmol})$ in methanol in an ACE-Glass pressure tube was added $\mathrm{Pd} / \mathrm{C}(10 \%)(7 \mathrm{mg}, 0.007 \mathrm{mmol})$. The resulting mixture was saturated with hydrogen gas 
( 3 cycles to $2.7 \mathrm{~atm}$ ) and stirred at room temperature for $1 \mathrm{~h}$. The reaction mixture was filtered through celite and the filtrate obtained was concentrated under reduced pressure. Purification of the crude product using $\mathrm{MeOH} / \mathrm{CHCl}_{3}(1: 4)$ afforded $165(30 \mathrm{mg}, 0.12 \mathrm{mmol}, 88 \%)$ as an amorphous white powder.

Analytical data for 165: $[\alpha]_{\mathrm{D}}^{21}=-40.0 \pm 0.1(c=0.005, \mathrm{MeOH}) ; \mathrm{mp}=91-93{ }^{\circ} \mathrm{C}\left(\right.$ lit: $\left.80-83{ }^{\circ} \mathrm{C}\right){ }^{1} \mathrm{H}$ NMR (400 MHz, CDCl $) \delta 7.93$ (brs, 1H), 7.07 (d, $J=8.8 \mathrm{~Hz}, 1 \mathrm{H}), 7.00$ (s, 1H), 6.65 (d, $J=8.4$ Hz, 1H), 4.67 (q, $J=6.4 \mathrm{~Hz}, 1 \mathrm{H}), 3.87$ (dd, $J=11.4,2.8 \mathrm{~Hz}, 1 \mathrm{H}), 3.79$ (s, 3H), 3.38 (dd, $J=14.8$, $2.8 \mathrm{~Hz}, 1 \mathrm{H}), 3.16(\mathrm{ddd}, J=15.2,11.8,1.6 \mathrm{~Hz}, 1 \mathrm{H}), 1.64(\mathrm{~d}, J=6.4 \mathrm{~Hz}, 3 \mathrm{H}) ;{ }^{13} \mathrm{C}$ NMR $(101 \mathrm{MHz}$, $\left.\mathrm{CDCl}_{3}\right) \delta 175.0,145.5,132.5,125.8,123.9,122.5,112.9,112.7,109.4,59.1,54.0,52.2,34.5$, 23.2; IR (ATR) 3823, 3693, 3652, 2031, 1566, 1341, 1254; HRMS (ESI) calcd for $\mathrm{C}_{14} \mathrm{H}_{17} \mathrm{~N}_{2} \mathrm{O}_{3}$ $\left(\mathrm{M}+\mathrm{H}^{+}\right) 261.1239$, found 261.1238 


\subsection{Supporting Information for Chapter 4: Aurantioclavine}

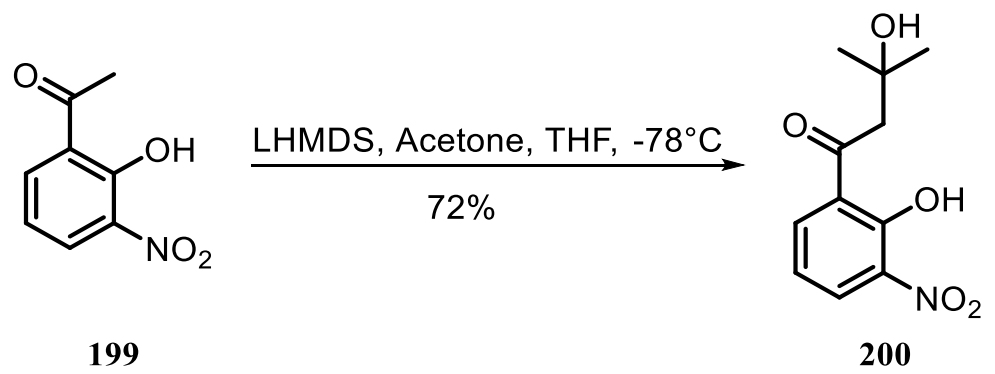

A solution of 2-hydroxy-3-nitroacetophenone 199 (513 mg, $2.83 \mathrm{mmol})$ in THF (15 mL) was added dropwise into a solution of LHMDS (1 M in THF) $(11.3 \mathrm{~mL}, 11.3 \mathrm{mmol})$ at $-78^{\circ} \mathrm{C}$ under argon atmosphere. The resulting mixture was stirred at $-78^{\circ} \mathrm{C}$ for $1 \mathrm{~h}$. To the stirred mixture was added acetone $(2.1 \mathrm{~mL}, 28.32 \mathrm{mmol})$ dropwise and continued to stir for $3 \mathrm{~h}$ at -78 ${ }^{\circ} \mathrm{C}$ before quenching with saturated $\mathrm{NH}_{4} \mathrm{Cl}$ solution $(15 \mathrm{~mL})$. The mixture was extracted with EtOAc $(3 \times 50 \mathrm{~mL})$. The combined organic layers were dried $\left(\mathrm{MgSO}_{4}\right)$, filtered and solvents were removed under reduced pressure. The crude product was purified by chromatography (MeOH/DCM, 1:99) affording, 200 (490 mg, 2.05 mmol, 72\%) as a yellow oil. Analytical data for 200: ${ }^{1} \mathrm{H}$ NMR $\left(400 \mathrm{MHz}, \mathrm{CDCl}_{3}\right) \delta 12.66($ br s, $1 \mathrm{H}), 8.22(\mathrm{dd}, J=8.4,2.0 \mathrm{~Hz}$, 1H), $8.08(\mathrm{dd}, J=8.0,1.6 \mathrm{~Hz}, 1 \mathrm{H}), 7.05(\mathrm{t}, J=8.4 \mathrm{~Hz}, 1 \mathrm{H}), 3.31(\mathrm{br} \mathrm{s}, 1 \mathrm{H}), 3.25(\mathrm{~s}, 2 \mathrm{H}), 1.37$ (s, $6 \mathrm{H}) ;{ }^{13} \mathrm{C} \mathrm{NMR}\left(100 \mathrm{MHz}, \mathrm{CDCl}_{3}\right) \delta 204.7,155.7,137.2,136.8,131.2,125.2,118.7,77.3,77.0$, 76.7, 70.2, 51.3, 29.6; IR (ATR) 3857, 3676, 3652, 2243, 1734, 1556, 1345; HRMS (ESI) calcd for $\mathrm{C}_{11} \mathrm{H}_{14} \mathrm{NO}_{5}\left(\mathrm{M}+\mathrm{H}^{+}\right)$240.0872, found 240.0869 .

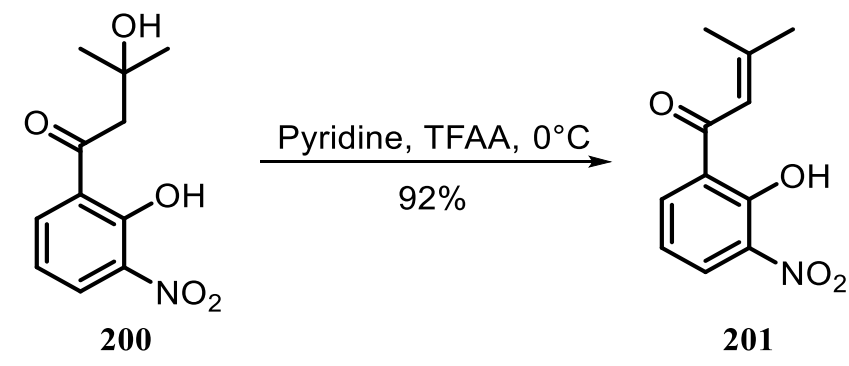


To a solution of $\mathbf{2 0 0}(1.13 \mathrm{~g}, 3.86 \mathrm{mmol})$ in pyridine $(7.7 \mathrm{~mL})$ under a nitrogen atmosphere was added trifluoroacetic anhydride $(1.1 \mathrm{~mL}, 7.72 \mathrm{mmol})$ at $0^{\circ} \mathrm{C}$. The resulting mixture was stirred $0{ }^{\circ} \mathrm{C}$ for $4 \mathrm{~h}$. The solvents were removed under reduced pressure and the crude product was purified by chromatography (EtOAc/hexanes, 5:95) affording 201 (784 mg, $3.54 \mathrm{mmol}, 92 \%)$ as yellow solid.

Analytical data for 201: $\mathrm{mp}=70-71{ }^{\circ} \mathrm{C} ;{ }^{1} \mathrm{H}$ NMR $\left(400 \mathrm{MHz}, \mathrm{CDCl}_{3}\right) \delta 13.77(\mathrm{~s}, 1 \mathrm{H}), 8.13(\mathrm{dd}, J=$ 8.0, 1.6 Hz, 1H), $8.04(\mathrm{dd}, J=8.4,1.6 \mathrm{~Hz}, 1 \mathrm{H}), 6.98(\mathrm{t}, J=8.0 \mathrm{~Hz}, 1 \mathrm{H}), 6.78(\mathrm{~m}, 1 \mathrm{H}), 2.27(\mathrm{~d}, J=$ $1.2 \mathrm{~Hz}, 3 \mathrm{H}), 2.09(\mathrm{~d}, J=1.2 \mathrm{~Hz}, 3 \mathrm{H}) ;{ }^{13} \mathrm{C} \mathrm{NMR}\left(100 \mathrm{MHz}, \mathrm{CDCl}_{3}\right) \delta 194.5,161.9,157.0,138.1$, 135.3, 130.9, 124.0, 119.7, 117.8, 28.5, 21.8; IR (ATR) 3035, 2961, 2022, 1763, 1596, 1312, $1197 \mathrm{~cm}^{-1}$; HRMS (ESI) calcd for $\mathrm{C}_{11} \mathrm{H}_{12} \mathrm{NO}_{4}\left(\mathrm{M}+\mathrm{H}^{+}\right)$222.0766, found 222.0762.

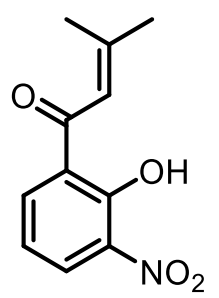

201
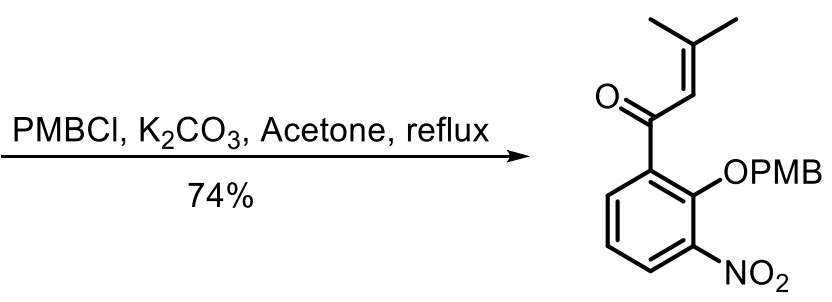

203

To a solution of $201(610 \mathrm{mg}, 2.76 \mathrm{mmol})$ in acetone $(28 \mathrm{~mL})$ was added solid potassium carbonate $(1.15 \mathrm{~g}, 8.29 \mathrm{mmol})$ and $p$-methoxybenzyl chloride $(520 \mathrm{mg}, 3.31 \mathrm{mmol})$. The resulting mixture was stirred under reflux for $54 \mathrm{~h}$. After cooling at ambient temperature, the reaction mixture was filtered through celite. The solvents were removed from the filtrate under reduced pressure. Water $(50 \mathrm{~mL})$ was added to the crude residue and the resulting mixture was extracted with EtOAc $(3 \times 80 \mathrm{~mL})$. Organic layers were combined and dried $\left(\mathrm{MgSO}_{4}\right)$, filtered and the filtrate was evaporated under reduced pressure. The crude product was purified by chromatography $\left(5 \% \mathrm{~K}_{2} \mathrm{CO}_{3}\right.$ added to silica gel, EtOAc/hexane, 5:95) affording 203 (700 mg, $2.05 \mathrm{mmol}, 74 \%$ ) as yellow oil. 
Analytical data for 203: ${ }^{1} \mathrm{H}$ NMR (400 MHz, DMSO-D $) ~ \delta 8.05(\mathrm{dd}, J=8.0,2.0 \mathrm{~Hz}, 1 \mathrm{H}), 7.78$ (dd, $J=7.6,1.6 \mathrm{~Hz}, 1 \mathrm{H}), 7.43(\mathrm{t}, J=8.0 \mathrm{~Hz}, 1 \mathrm{H}), 7.21(\mathrm{~m}, 2 \mathrm{H}), 6.93(\mathrm{~m}, 2 \mathrm{H}), 6.57(\mathrm{~m}, 1 \mathrm{H}), 4.86$ (s, 2H), 3.76 (s, 3H), 2.20 (d, $J=1.2 \mathrm{~Hz}, 3 \mathrm{H}), 1.92$ (d, $J=1.2 \mathrm{~Hz}, 3 \mathrm{H}) ;{ }^{13} \mathrm{C}$ NMR $(101 \mathrm{MHz}$, DMSO-D $\left._{6}\right) \delta 190.6,160.0,159.3,149.0,145.2,138.0,134.1,130.7,127.8,127.5,125.4,124.2$, 114.3, 114.0, 78.6, 55.6, 28.0, 21.5; IR (ATR) 3041, 2974, 1898, 1740, 1586, $1336 \mathrm{~cm}^{-1}$; HRMS (ESI) calcd for $\mathrm{C}_{19} \mathrm{H}_{20} \mathrm{NO}_{5}\left(\mathrm{M}+\mathrm{H}^{+}\right)$342.1342, found 342.1336.

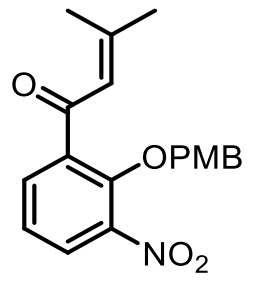

203

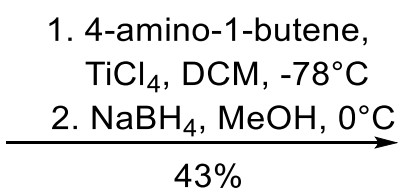

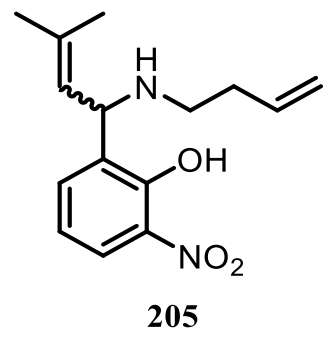

205

To a mixture of 203 (360 mg, $1.05 \mathrm{mmol})$ in DCM (5 mL) was added 4-amino-1-butene (450 mg, $6.33 \mathrm{mmol})$. The resulting mixture was cooled to $-78{ }^{\circ} \mathrm{C}$ and $\mathrm{TiCl}_{4}(1 \mathrm{M}$ in DCM) $(1.2$ $\mathrm{mL}, 1.2 \mathrm{mmol}$ ) solution was added dropwise. After stirring at $-78^{\circ} \mathrm{C}$ for $4 \mathrm{~h}, \mathrm{NaBH}_{4}(60 \mathrm{mg}$, $1.58 \mathrm{mmol})$ and methanol $(5 \mathrm{~mL})$ were added. The resulting mixture was allowed to warm to $0^{\circ} \mathrm{C}$ and stirred for $1 \mathrm{~h}$. To the stirred mixture was added $0.5 \mathrm{~N} \mathrm{NaOH}(20 \mathrm{~mL})$ and extracted with EtOAc $(3 \times 50 \mathrm{~mL})$. The combined organic layers were dried $\left(\mathrm{MgSO}_{4}\right)$, filtered and solvents were removed under reduced pressure. The crude product was purified by chromatography (EtOAc/hexane, 2:8) affording 205 (126 $\mathrm{mg}, 0.46 \mathrm{mmol}, 43 \%)$ as a yellow solid. Analytical data for $205: \mathrm{mp}=128-130^{\circ} \mathrm{C} ; \delta 7.85(\mathrm{dd}, J=8.4,1.6 \mathrm{~Hz}, 1 \mathrm{H}), 7.29(\mathrm{~d}, J=7.6 \mathrm{~Hz}$, 1H), $6.77(\mathrm{t}, J=7.6 \mathrm{~Hz}, 1 \mathrm{H}), 5.76(\mathrm{~m}, 1 \mathrm{H}), 5.34(\mathrm{dt}, J=9.6,1.6 \mathrm{~Hz}, 1 \mathrm{H}), 5.12(\mathrm{~m}, 2 \mathrm{H}), 4.74(\mathrm{~d}$, $J=9.2 \mathrm{~Hz}, 1 \mathrm{H}), 2.73(\mathrm{~m}, 2 \mathrm{H}), 2.33(\mathrm{~m}, 2 \mathrm{H}), 1.75(\mathrm{~s}, 6 \mathrm{H}) ;{ }^{13} \mathrm{C} \mathrm{NMR}\left(100 \mathrm{MHz}, \mathrm{CDCl}_{3}\right) \delta$ 136.9, 136.8, 135.0, 133.6, 129.9, 124.7, 123.3, 117.6, 117.5, 58.9, 45.5, 33.4, 25.8, 18.3; IR (ATR) 
$3352,2973,2221,1833,1586,1456,1243,1053 \mathrm{~cm}^{-1}$; HRMS (ESI) calcd for $\mathrm{C}_{15} \mathrm{H}_{21} \mathrm{~N}_{2} \mathrm{O}_{3}$ $\left(\mathrm{M}+\mathrm{H}^{+}\right) 277.1552$, found 277.1551 


\section{References and Notes}

1. Baeyer, A.; Knopp, C. A. Chemische Berichte. 1868, 1, 17.

2. Barden, T. C. Top. Heterocycl. Chem. 2010, 26, 31.

3. Evans, B. E.; Rittle, K. E.; Bock, M. G.; DiPardo, R. M.; Freidinger, R. M.; Whitter, W. L.; Lundell, G. F.; Veber, D. F.; Anderson, P. S.; Chang, R. S. L.; Lotti, V. J.; Cerino, D. J.; Chen, T. B.; Kling, P. J.; Kunkel, K. A.; Springer, J. P.; Hirshfield, J. J. Med. Chem. 1988, 3, 2235

4. Horton, D. A.; Bourne, G. T.; Smythe, M. L. Chem. Rev. 2003, 103, 893

5. Wu, Y.J. Top. Heterocycl. Chem. 2010, 26, 1

6. Corey, E. J.; Czako, B.; Kurti, L. Molecules and medicine, 2007, Wiley, Hoboken, NJ

7. Taber, D. F.; Tirunahari, P. K.; Tetrahedron. 2011, 67, 7195

8. Hegedus, L. S.; Allen, G. F.; Waterman, E. L. J. Am. Chem. Soc. 1976, 98, 2674.

9. Larock, R. C.; Yum, E. K.; Refvik, M. D. J. Org. Chem. 1998, 63, 7652-7662.

10. Newhouse, T.; Baran, P. S. J. Am. Chem. Soc. 2008, 130, 10886-10887.

11. Gribble, G. W. Indole Ring Synthesis: From Natural Products to Drug Discovery, 2016, 604606, John Wiley \& Sons Ltd

12. Akazome, M.; Kondo, T.; Watanabe, Y. J. Org. Chem. 1994, 59, 3375.

13. Söderberg, B. C.; Shriver, J. A. J. Org. Chem. 1997, 62, 5838.

14. Dacko, C. A.; Akhmedov, N. G.; Söderberg, B. C. G. Tetrahedron Asymm. 2008, 19, 27752783.

15. Gorugantula, S. P.; Carrero-Martinez, G. M.; Dantale, S. W.; Söderberg, B. C. G. Tetrahedron 2010, 66, 1800-1805.

16. Clawson Jr., R. W.; Dacko, C. A.; Deavers III, R. E.; Akhmedov, N. G.; Söderberg, B. C. G. 
Tetrahedron 2009, 65, 8786-8793.

17. Clawson Jr., R. W.; Söderberg, B. C. G. Tetrahedron Lett. 2007, 48, 6019-6021.

18. Scott, T. L.; Söderberg, B. C. G. Tetrahedron 2003, 59, 6323-6332.

19. Dantale, S. W.; Söderberg, B. C. G. Tetrahedron 2003, 59, 5507-5514.

20. Scott, T. L.; Yu, X.; Gorunatula, S. P.; Carrero-Martínez, G.; Söderberg, B. C. G. Tetrahedron 2006, 62, 10835-10842.

21. Söderberg, B. C.; Chisnell, A. C.; O'Neil, S. N.; Shriver, J. A. J. Org. Chem. 1999, 64, 97319734.

22. Clawson, R. W., Jr.; Deavers, R. E., III; Akhmedov, N. G.; Söderberg, B. C. G. Tetrahedron 2006, 62, 10829.

23. Zhang, Y.; Hubbard, J. W.; Akhmedov, N. G.; Petersen, J. L.; Söderberg, B. C. G. J. Org. Chem. 2015, 80, 4783-4790.

24. Cummings, M. M.; Clawson, R. W.; Sharma, S. B.; Byerly, R. A.; Akhmedov, N. G.; Söderberg, B. C. G. Tetrahedron 2011, 67, 4753-4757.

25. Ghimire, G.; Söderberg, B. C. G. Tetrahedron Lett. 2016, 57, 3873-3876.

26. Moss, G. P. Pure \& Appl. Chem. 1998, 70, 143-216

27. Kozlovski, A. G.; Soloveva, T. F.; Sakharovskii, V. G.; Adanin, V. M. Dokl. Akad. Nauk. SSSR $1981,260,230-233$.

28. King, G. S.; Waight, E. S.; Mantle, P. G.; Szcyrbak, C. A. J. Chem. Soc., Perkin Trans 1 1977, 2099-2103.

29. Yamanokuchi, R.; Imada, K.; Miyazaki, M.; Kato, H.; Watanabe, T.; Fujimuro, M.; Saeki, Y.; Yoshinaga, S.; Terasawa, H.; Iwasaki, N.; Rotinsulu, H.; Losing, F.; Mangindaan, R. E. P.; 
Namikoshi, M.; de Voogd, N. J.; Yokosawa, H.; Tsukamoto, S. Bioorg. Med. Chem. 2012, 20, 4437-4442.

30. Qu, S.-J.; Liu, Q.-W.; Tan, C.-H.; Jiang, S.-H.; Zhu, D.-Y. Planta Med. 2006, 72, 264-266.

31. Nikolic, D.; Gödecke, T.; Chen, S.-N.; White, J.; Lankin, D. C.; Pauli, G. F.; van Breemen, R. B. Fitoterapia 2012, 83, 441-460.

32. Ito, F.; Shudo, K.; Yamaguchi, K. Tetrahedron 2011, 67,1805

33. a) Kozikowski, A. P.; Greco, M. N. Heterocycles 1982, 19, 2269-2273. b) Harrington, P. J.; Hegedus, L. S.; McDaniel, K. F. J. Am. Chem. Soc. 1987, 109, 4335-4338. c) Matsumoto, M.; Kobayashi, H.; Watanabe, N. Heterocycles 1987, 26, 1197-1202. d) Boyles, D. A.; Nichols, D. E. J. Org. Chem. 1988, 53, 5128-5130. e) Somei, M.; Hamamoto, S.; Nakagawa, K.; Yamada, F.; Ohta, T. Heterocycles 1994, 37, 719-724. f) Yokoyama, Y.; Matsumoto, T.; Murakami, Y. J. Org. Chem. 1995, 60, 1486-1487. g) Shinohara, H.; Fukuda, T.; Iwao, M.

Tetrahedron 1999, 55, 10989-11000. h) Yokoyama, Y.; Hikawa, H.; Mitsuhashi, M.; Uyama, A.; Murakami, Y. Tetrahedron Lett. 1999, 40, 7803-7806. i) Ku, J.-M.; Jeong, B.-S.; Jew, S.S.; Park, H.-G. J. Org. Chem. 2007, 72, 8115-8118. j) Xu, Z.; Hu, W.; Liu, Q.; Zhang, L.; Jia, Y.J. Org. Chem. 2010, 75, 7626-7635. k) Liu, Q.; Li, Q.; Ma, Y.; Jia, Y. Org. Lett. 2013, 15, 4528-4531. 1) Bartoccini, F.; Casoli, M.; Mari, M.; Piersanti, G. J. Org. Chem. 2014, 79, 3255-3259. m) Tahara, Y.-k.; Ito, M.; Kanyiva, K. S.; Shibata, T. Chem-Eur. J. 2015, 21, 11340-11343.

34. a) Yamada, F.; Makita, Y.; Suzuki, T.; Somei, M. Chem. Pharm. Bull. 1985, 33, 2162-2163. b) Hegedus, L. S.; Toro, J. L.; Miles, W. H.; Harrington, P. J. J. Org. Chem. 1987, 52, 3319-3322. c) Somei, M.; Yamada, F. Heterocycles 2007, 74, 943-950. d) Lei, T.; Zhang, H.; Yang, Y.-R. Tetrahedron Lett. 2015, 56, 5933-5936. 
35. a) Krishnan, S.; Bagdanoff, J. T.; Ebner, D. C.; Ramtohul, Y. K.; Tambar, U. K.; Stoltz, B. M. J. Am. Chem. Soc. 2008, 130, 13745-13754. b) Brak, K.; Ellman, J. A. Org. Lett. 2010, 12, 2004-2007.

36. Yamada, K.; Namerikawa, Y.; Haruyama, T.; Miwa, Y.; Yanada, R.; Ishikura, M. Eur. J. Org. Chem. 2009, 33, 5752-5759.

37. Nikolic, D.; Gödecke, T.; Chen, S.-N.; White, J.; Lankin, D. C.; Pauli, G. F.; van Breemen, R. B. Fitoterapia 2012, 83, 441-460.

38. Muratake, H.; Takahashi, T.; Natsume, M. Heterocycles 1983, 20, 1963-1968.

39. Xu, Z.; Li, Q.; Zhang, L.; Jia, Y. J. Org. Chem. 2009, 74, 6859-6862.

40. Suetsugu, S.; Nishiguchi, H.; Tsukano, C.; Takemoto, Y. Org. Lett. 2014, 16, 996-999.

41. a) Shan, D.; Gao, Y.; Jia, Y. Angew. Chem., Int. Ed. 2013, 52, 4902-4905. b) Gao, Y.; Shan, D.; Jia, Y. Tetrahedron 2014, 70, 5136-5141.

42. Bartoccini, F.; Casoli, M.; Mari, M.; Piersanti, G. J. Org. Chem. 2014, 79, 3255.

43. a)Yamada, K.; Namerikawa, Y.; Haruyama, T.; Miwa, Y.; Yanada, R.; Ishikura, M. Eur. J. Org. Chem., 2009, 5752. b) Yamada, K.; Namerikawa, Y.; Abe, T.; Ishikura, M. Heterocycles 2009, 77, 825-828 c) Abe, T.; Yamada, K.; J. Nat. Prod. 2017, 80, 241-245 d) Abe, T.;

Haruyama, T.; Yamada, K. Synthesis 2017, 49, 4141-4150

44. Xu, Z.; Li, Q.; Zhang, L.; Jia, Y. J. Org. Chem. 2009, 74, 6859.

45. Ito, F.; Shudo, K.; Yamaguchi, K. Tetrahedron 2011, 67, 1805

46. Tahara, Y. K.; Ito, M.; Kanyiva, K. S.; Shibata, T. Chem. Eur. J. 2015, 21, 11340.

47. Liu, Q.; Li, Q.; Ma, Y.; Jia, Y. Org. Lett. 2013, 15, 4528.

48. Krishnan, S.; Bagdanoff, J. T.; Ebner, D. C.; Ramtohul, Y. K.; Tambar, U. K.; Stoltz, B. M. J. Am. Chem. Soc., 2008, 130, 13745. 
49. Brak, K.; Ellman, J. A. Org. Lett. 2010, 12, 2004-2007.

50. Cheng, D.-J.; Wu, H.-B.; Tian, S.-K. Org. Lett. 2011, 13, 5636

51. Kumar, A.; Li, Z.; Sharma, S. K.; Parmar, V. S.; Van der Eycken, E. V. Chem. Commun. 2013, 49,6803 .

52. Xu, Q.-L.; Dai, L.-X.; You, S.-L. Chem. Sci. 2013, 4, 97.

53. Tanaka, Y.; Suzuki, Y.; Hamada, Y.; Nemoto, T. Heterocycles 2017, 95, 243

54. a) Inouye, M.; Ueno, M.; Kitao, T. J. Org. Chem. 1992, 57, 1639-1641; (b) Inouye, M.;

Akamatsu, K.; Nakazumi, H. J. Am. Chem. Soc. 1997, 119, 9160-9165

55. Söderberg, B. C. G.; Hubbard, J. W.; Rector, S. R.; O’Neil, S. N. Tetrahedron 2005, 61, 36373649.

56. a) Foley, D. J.; Doveston, R. G.; Churcher, I. Nelson, A.; Marsden, S. P. Chem. Commun. 2015, 51, 11174-11177. b) Ferraccioli, R.; Carenzi, D.; Catellani, M. Synlett 2002, 1860-1864

57. Qu, S.-J.; Wang, G.-F.; Duan, W.-H.; Yao, S.-Y.; Zuo, J.-P.; Tan, C.-H.; Zhu, D.-Y. Bioorg. Med. Chem. 2011, 19, 3120-3127.

58. Yamanokuchi, R.; Imada, K.; Miyazaki, M.; Kato, H.; Watanabe, T.; Fujimuro, M.; Saeki, Y.; Yoshinaga, S.; Terasawa, H.; Iwasaki, N.; Rotinsulu, H.; Losung, F.; Mangindaan, R.;

Namikoshi, M.; de Voogd, N.; Yokosawa, H.; Tsukamoto, S. Bioorg. Med. Chem. 2012, 20, 4437-4442.

59. Imada, K.; Sakai, E.; Kato, H.; Kawabata, T.; Yoshinaga, S.; Nehira, T.; Terasawa, H.; Tsukamoto, S. Tetrahedron 2013, 69, 7051-7055.

60. Zhang, X.; Li, Y.; Shi, H.; Zhang, L.; Zhang, S.; Xu, X.; Liu, Q. Chem. Commun. 2014, 50, 7306-7309. 
61. a) Yang, L.; Ma, Y.; Song, F.; You, J. Chem. Commun. 2014, 50, 3024. b) Utsunomiya, M.; Kuwano, R.; Kawatsura, M.; Hartwig, J. F. J. Am. Chem. Soc. 2003, 125, 5608-5609

62. Cushman, M.; Zhu, H.; Geahlen, R. L.; Kraker, A. J. J. Med. Chem. 1994, 37, 3353-3362.

63. a) Qin, L.; Ren, X.; Lu, Y.; Li, Y.; Zhou, J. Angew. Chem. Int. Ed. 2012, 51, 5915. b) Qin, L.; Hirao, H.; Zhou, J. Chem. Commun. 2013, 49, 10236

64. Lin, H.C.; Chiou, G.; Chooi, Y. H.; McMahon, T. C.; Xu, W., Garg, N.K.; Tang, Y. Angew. Chem., Int. Ed., 2015, 54, 3004-3007.

65. a) Ferreira, E. M.; Stoltz, B. M. J. Am. Chem. Soc. 2001, 123, 7725. b) Jensen, D. R.; Pugsley, J. S.; Sigman, M. S. J. Am. Chem. Soc. 2001, 123, 7475.

66. Ikota, H.; Tsukano, C.; Takemoto, Y. Heterocycles 2018 (DOI: 10.3987/COM-18-S(T)49) (in press) 


\section{Appendix}

\section{${ }^{1} \mathrm{H}$ and ${ }^{13} \mathrm{C}$ NMR Spectra}

- $\quad{ }^{1} \mathrm{H}$ and ${ }^{13} \mathrm{C}$ NMR for Chapter 2: Cimitrypazepine and Fargesine

- ${ }^{1} \mathrm{H}$ and ${ }^{13} \mathrm{C}$ NMR for Chapter 3: Hyrtioreticulins C \& D

- ${ }^{1} \mathrm{H}$ and ${ }^{13} \mathrm{C}$ NMR for Chapter 4: Aurantioclavine 
${ }^{1} \mathrm{H}$ and ${ }^{13} \mathrm{C}$ NMR for Chapter 2: Cimitrypazepine and Fargesine
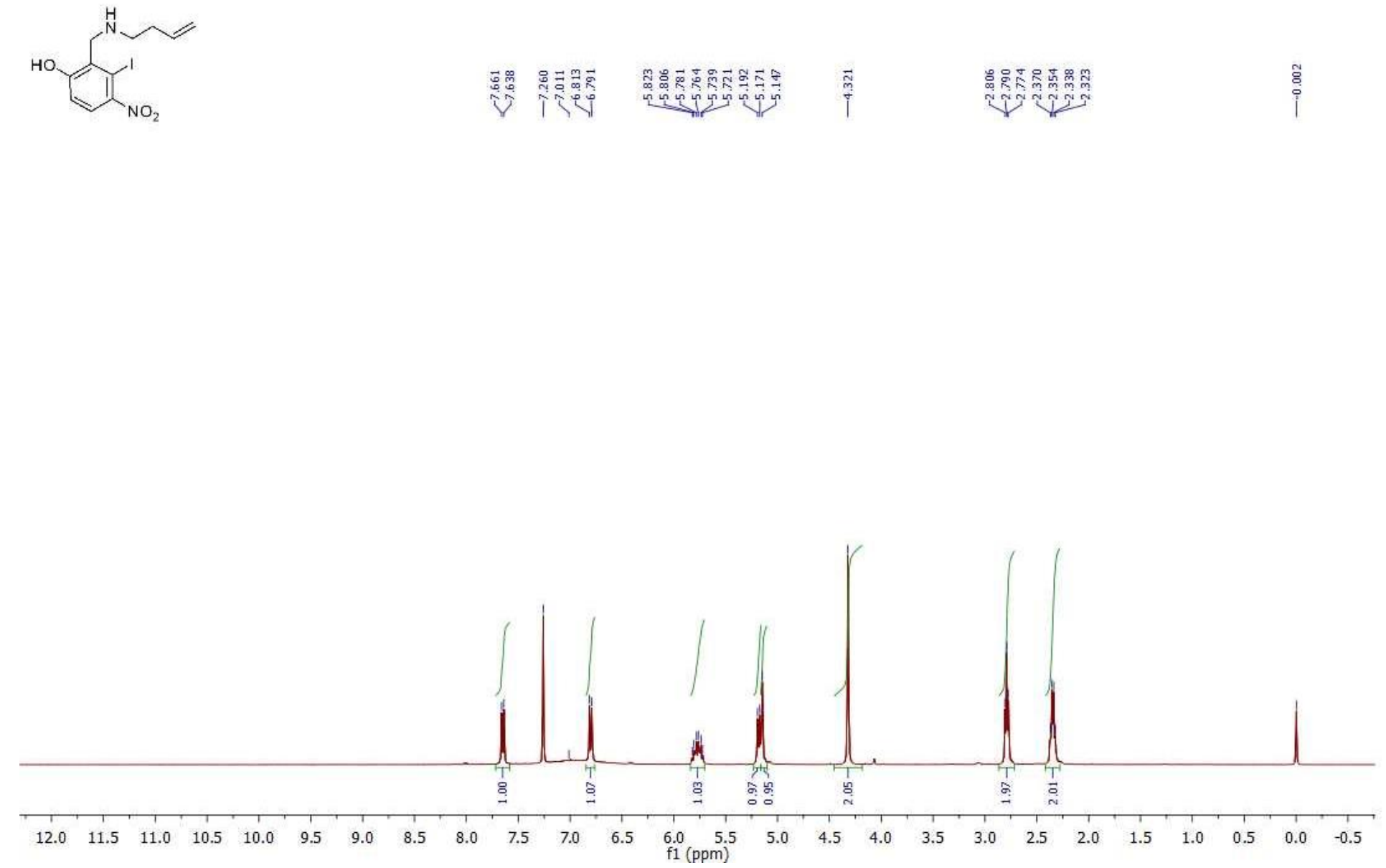

Figure 9: ${ }^{1} \mathrm{H}$ NMR of Compound 95 
<smiles>C=CCCNc1c(O)ccc([N+](=O)[O-])c1C</smiles>

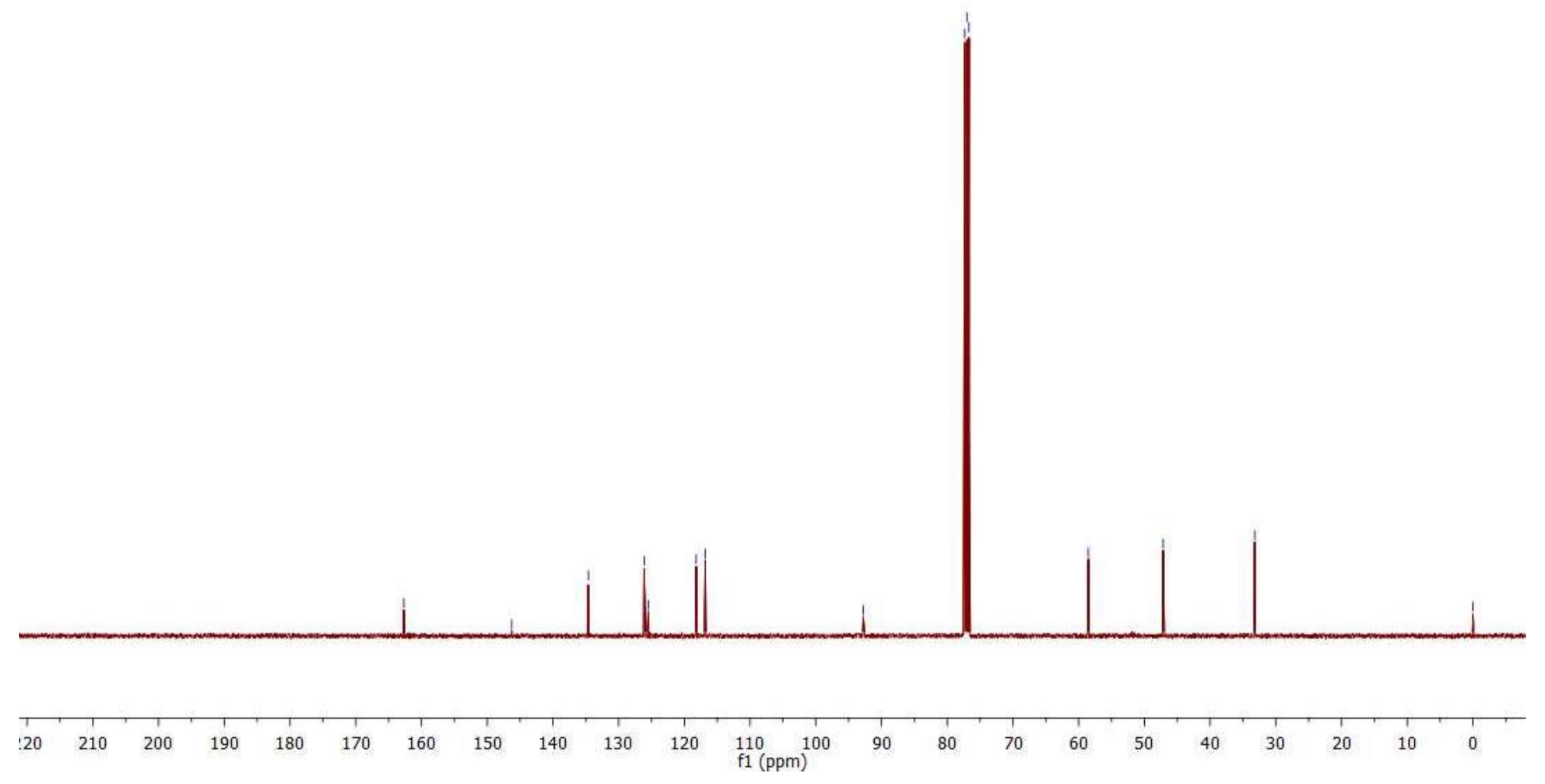

Figure 10: ${ }^{13} \mathrm{C}$ NMR of Compound 95 


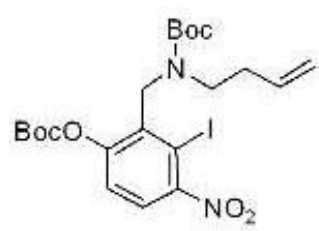

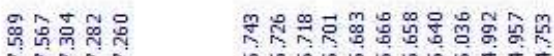

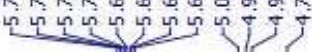

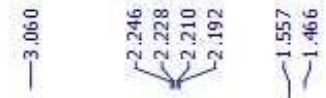

$\mathrm{NO}_{2}$

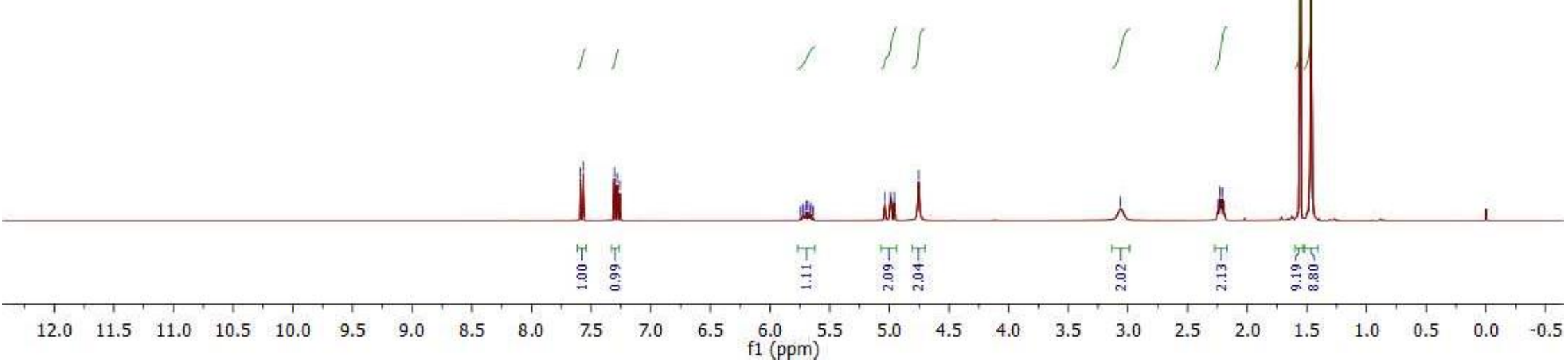

Figure 11: ${ }^{1} \mathrm{H}$ NMR of Compound 97 

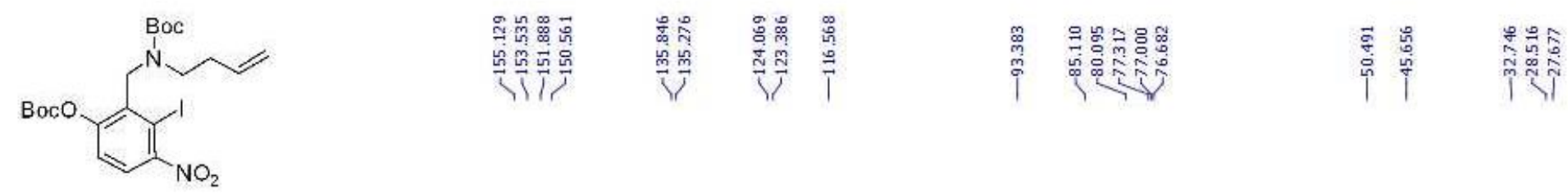

$\mathrm{NO}_{2}$
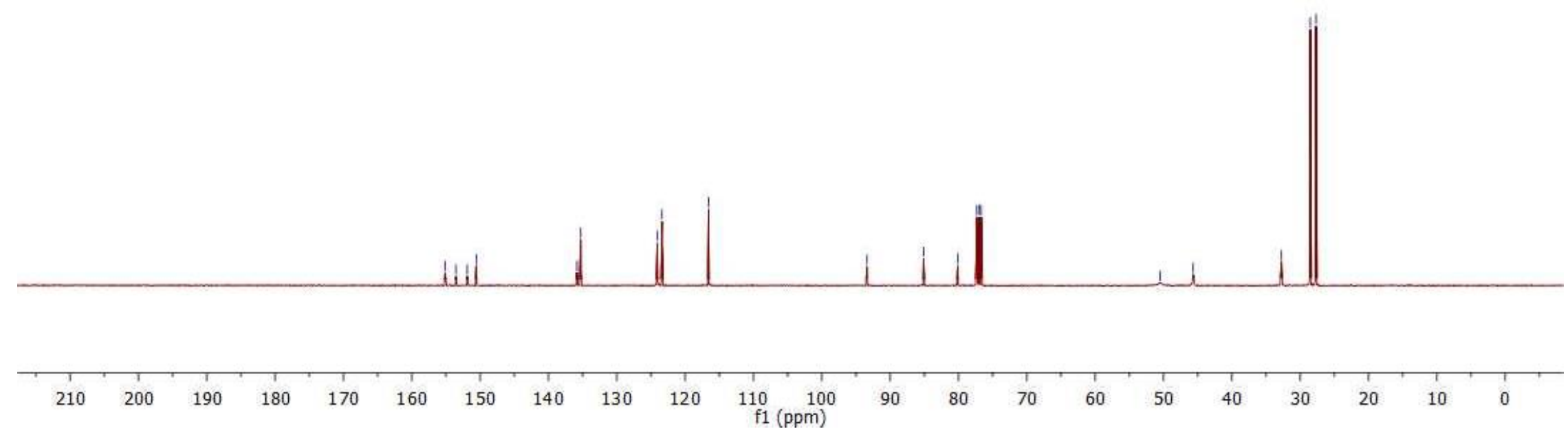

Figure 12: ${ }^{13} \mathrm{C}$ NMR of Compound 97 


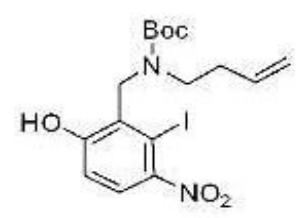

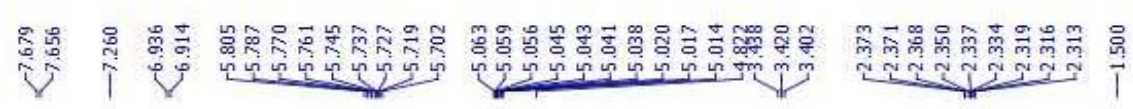

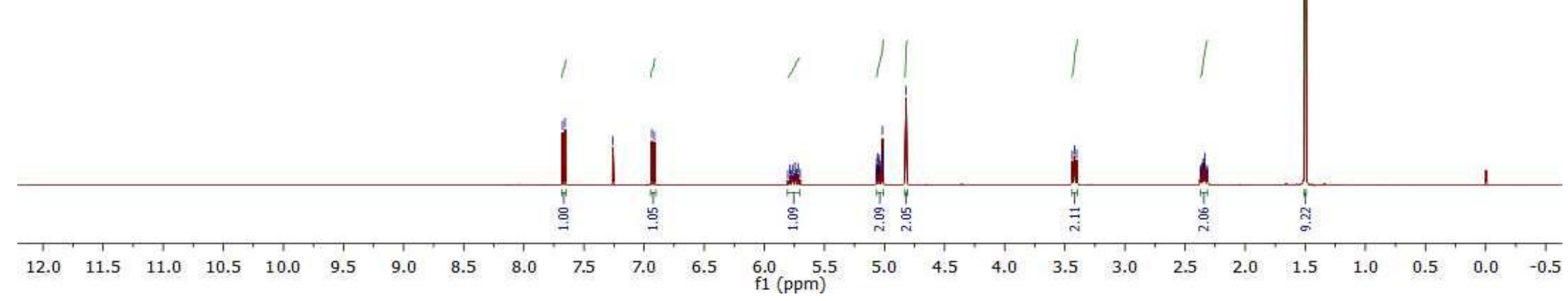

Figure 13: ${ }^{1} \mathrm{H}$ NMR of Compound 98 

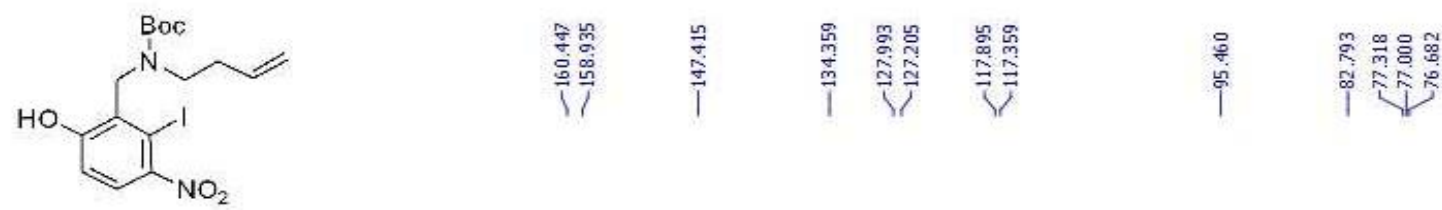

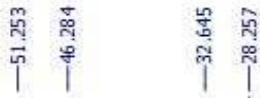
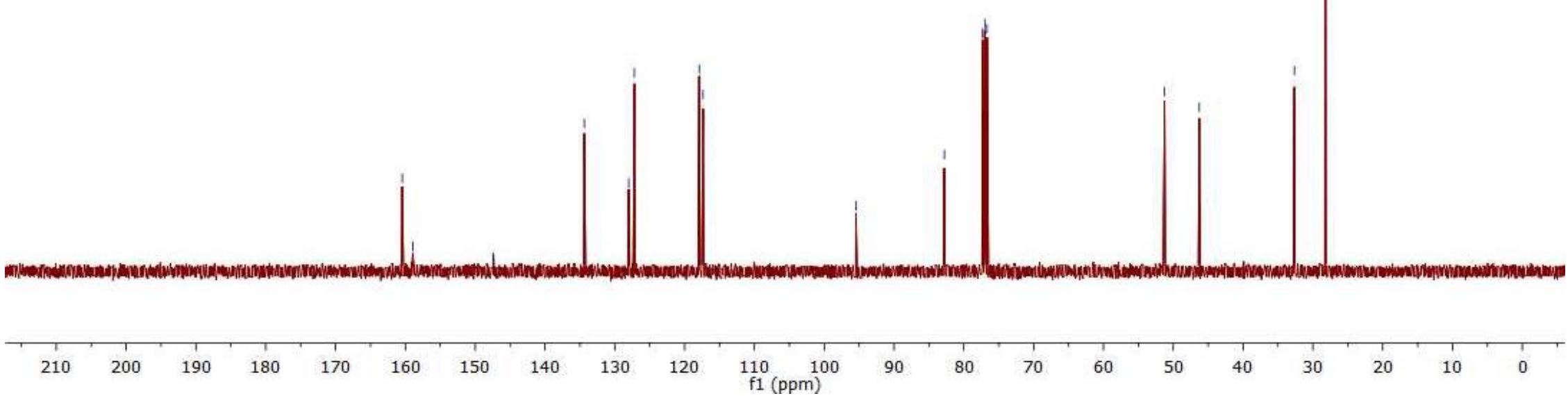

Figure 14: ${ }^{13} \mathrm{C}$ NMR of Compound 98 


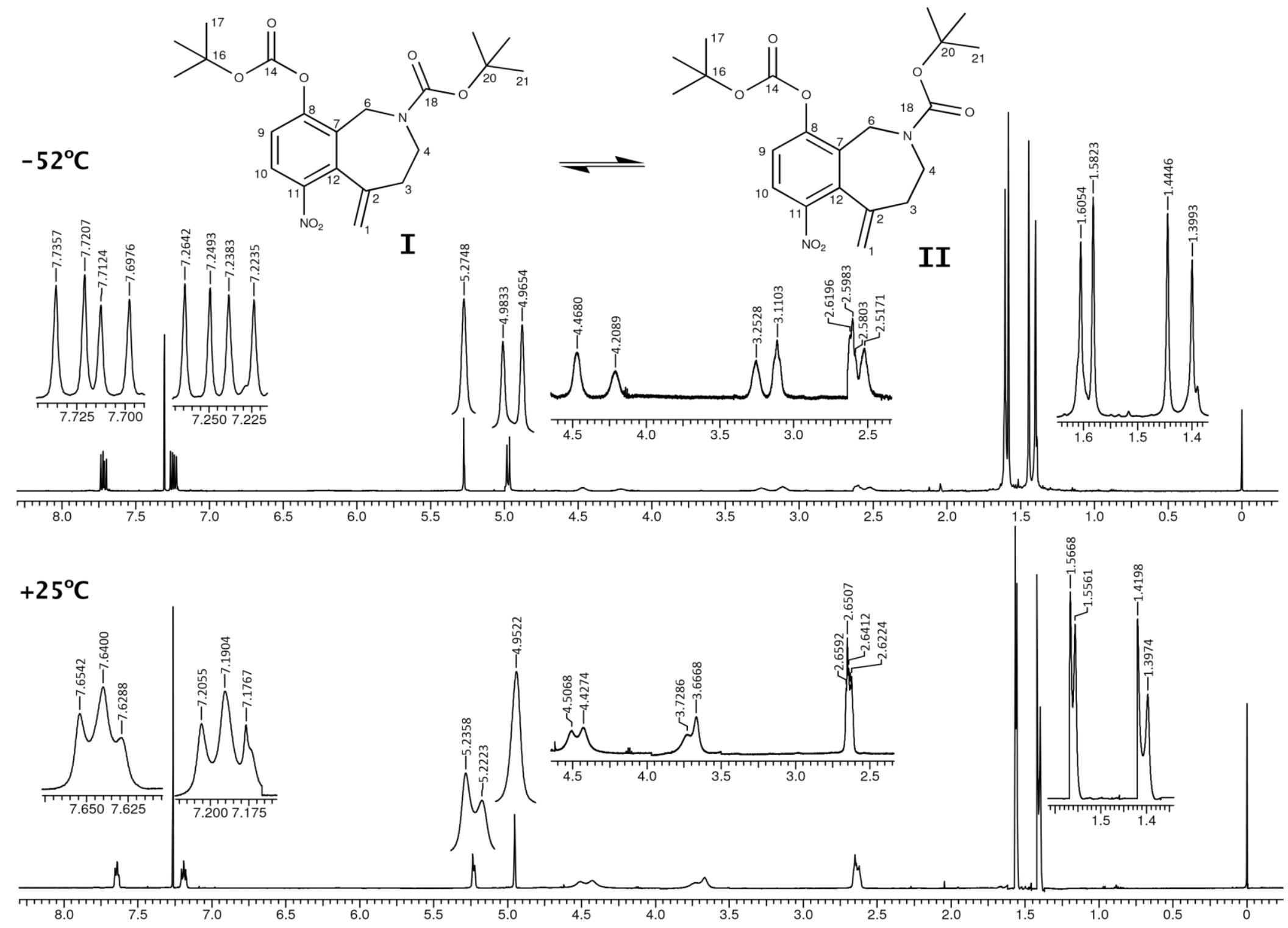

Figure 15: ${ }^{1} \mathrm{H}$ NMR of Compound 101 


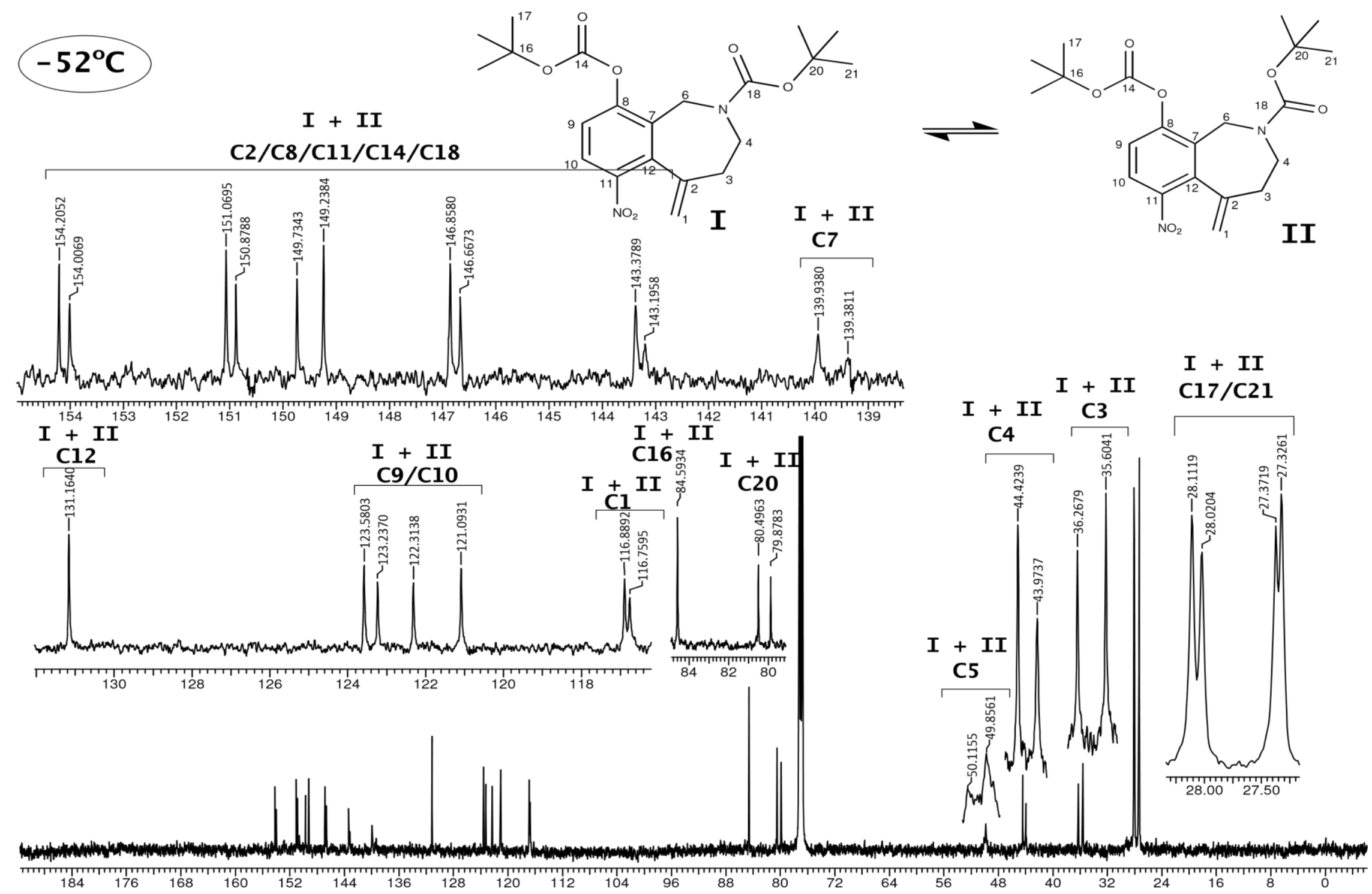

Figure 16: ${ }^{13} \mathrm{C}$ NMR of Compound 101 

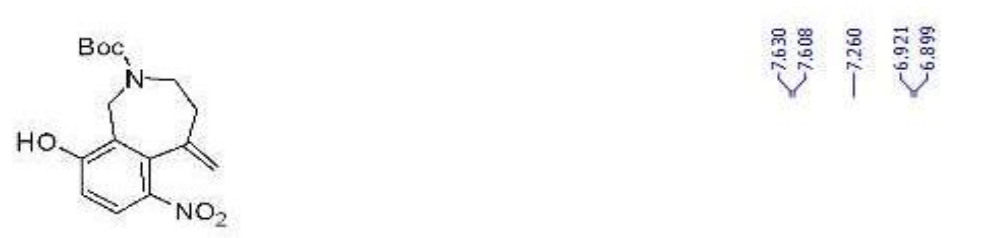

कै
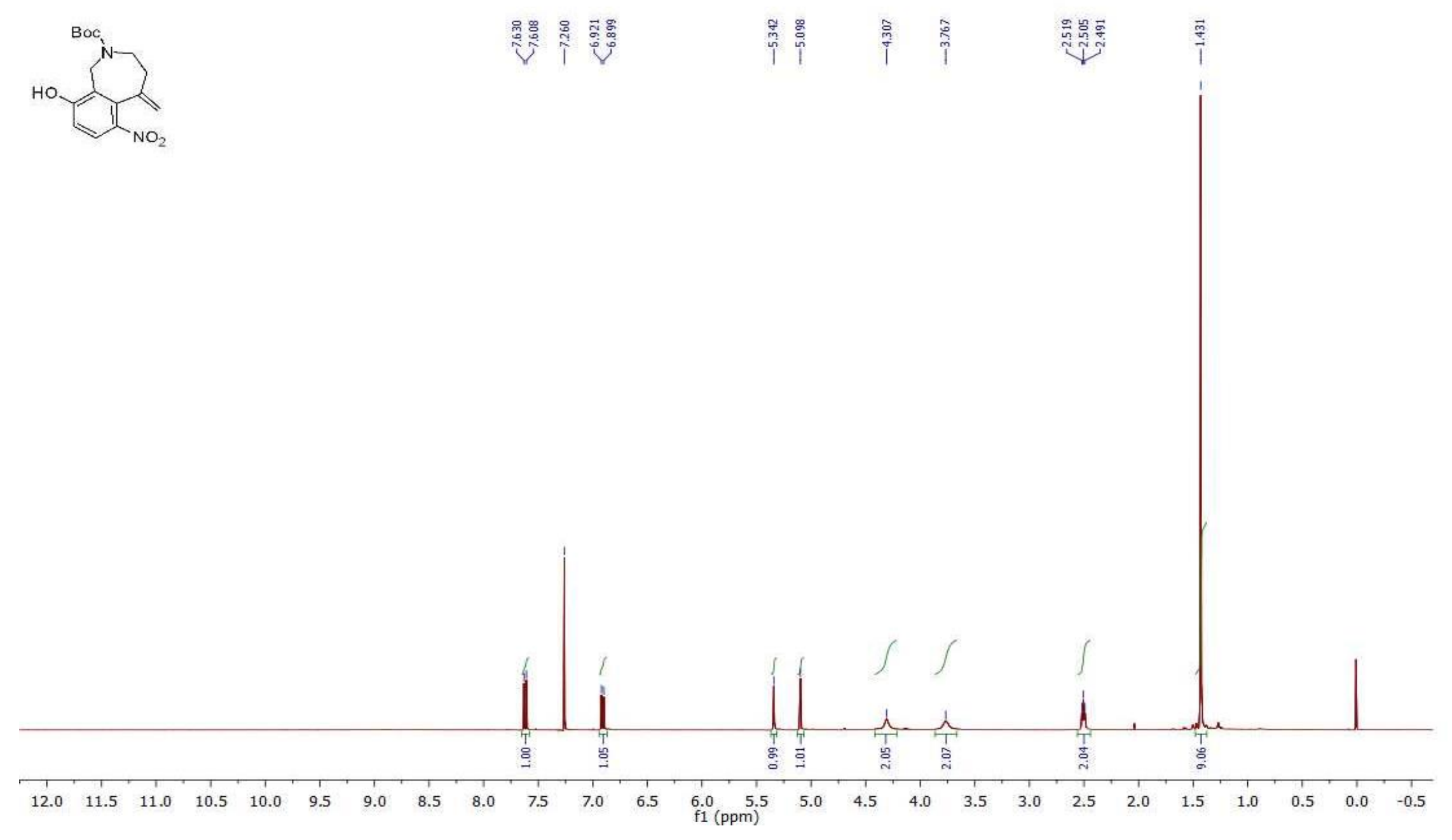

Figure 17: ${ }^{1} \mathrm{H}$ NMR of Compound 102 

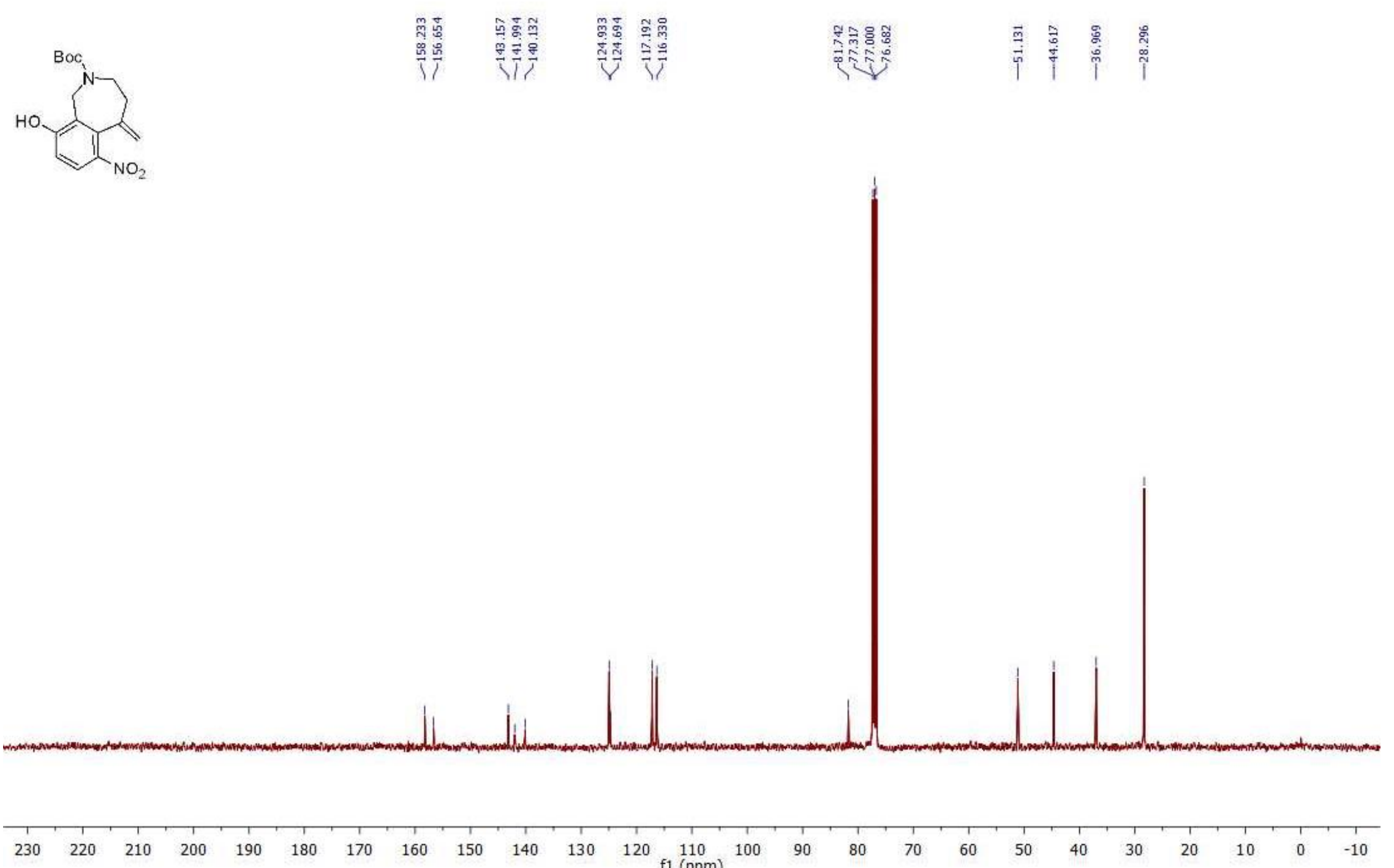

Figure 18: ${ }^{13} \mathrm{C}$ NMR of Compound 102 

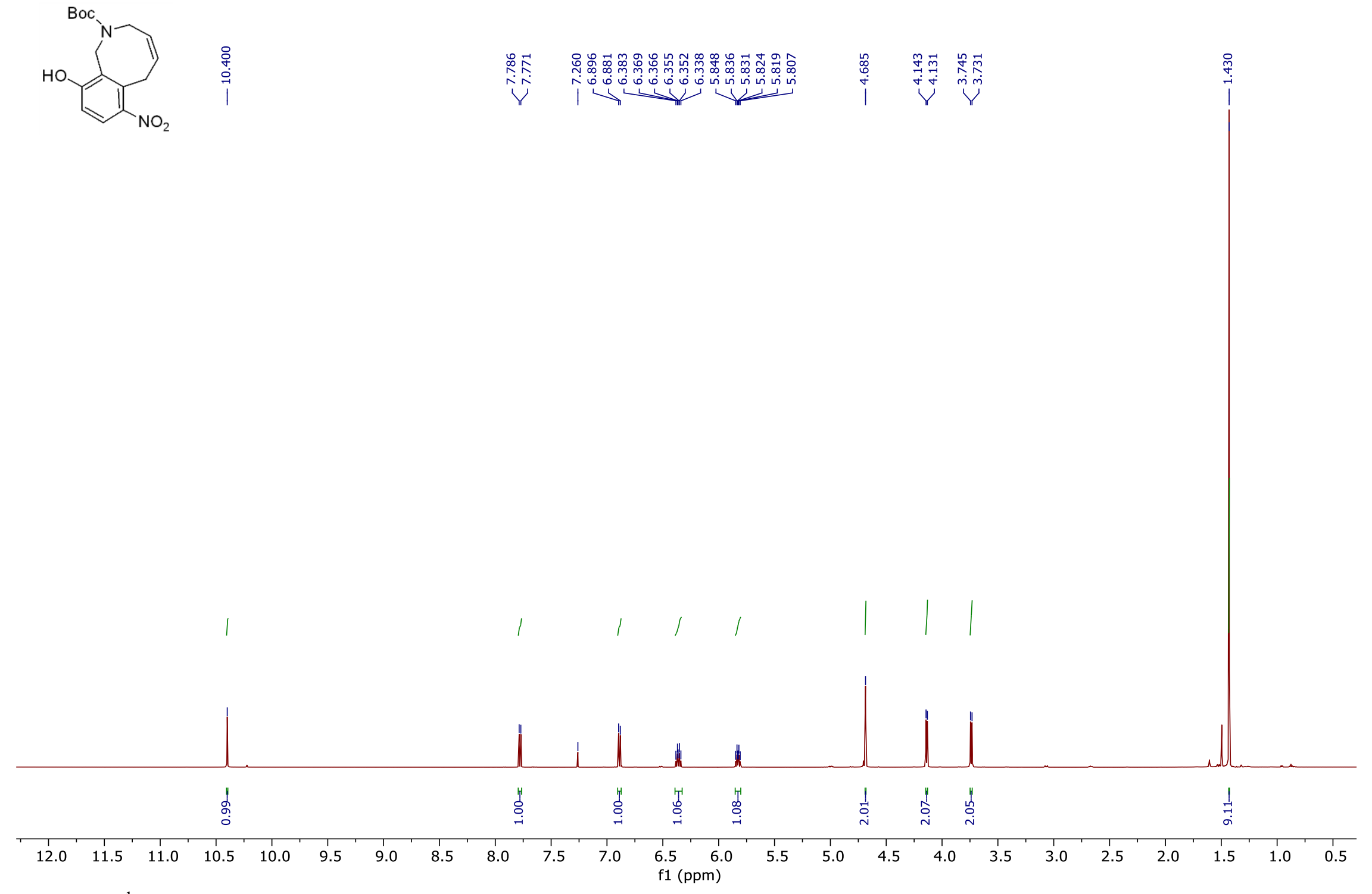

Figure 19: ${ }^{1} \mathrm{H}$ NMR of Compound 103 

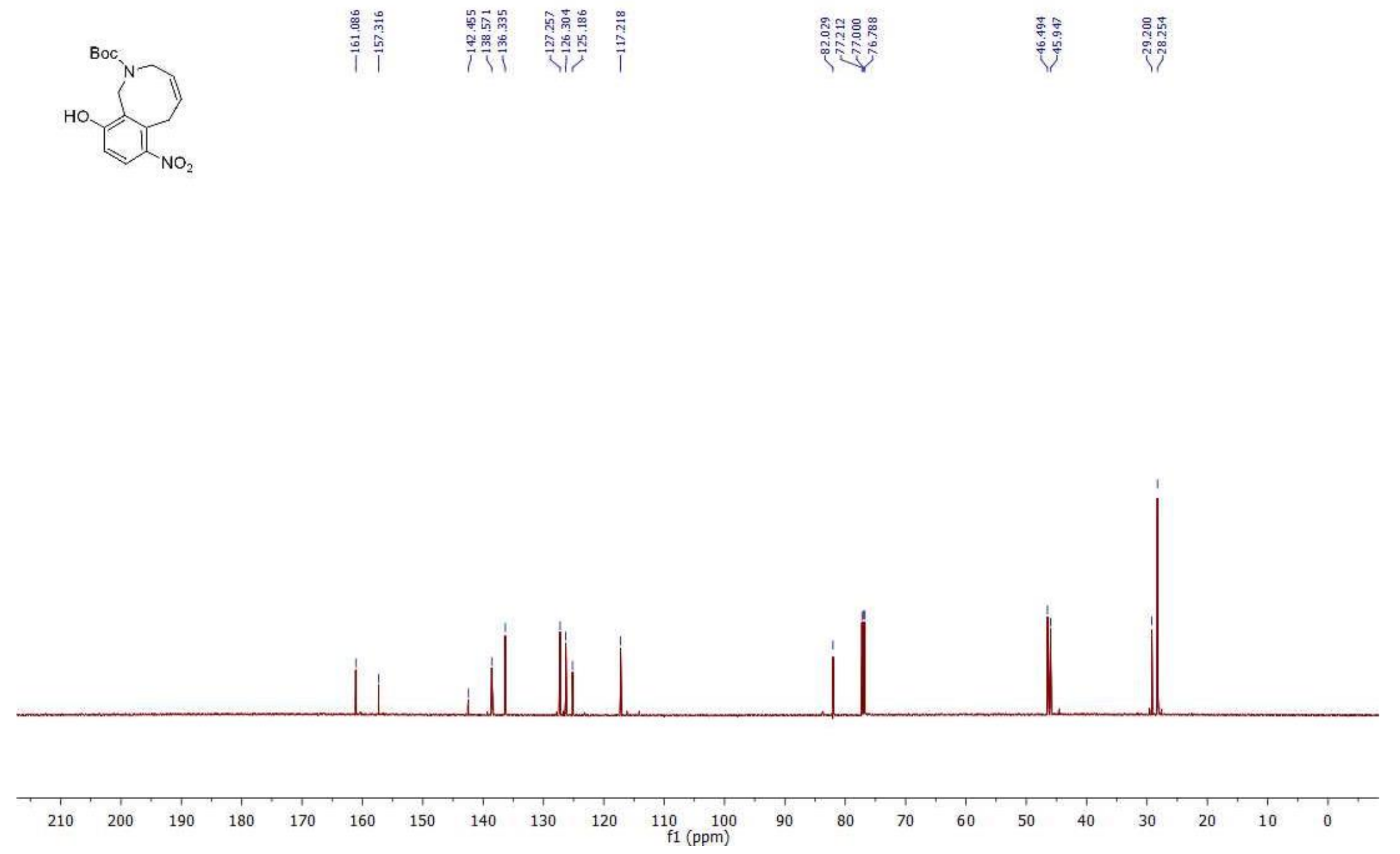

Figure 20: ${ }^{13} \mathrm{C}$ NMR of Compound 103 


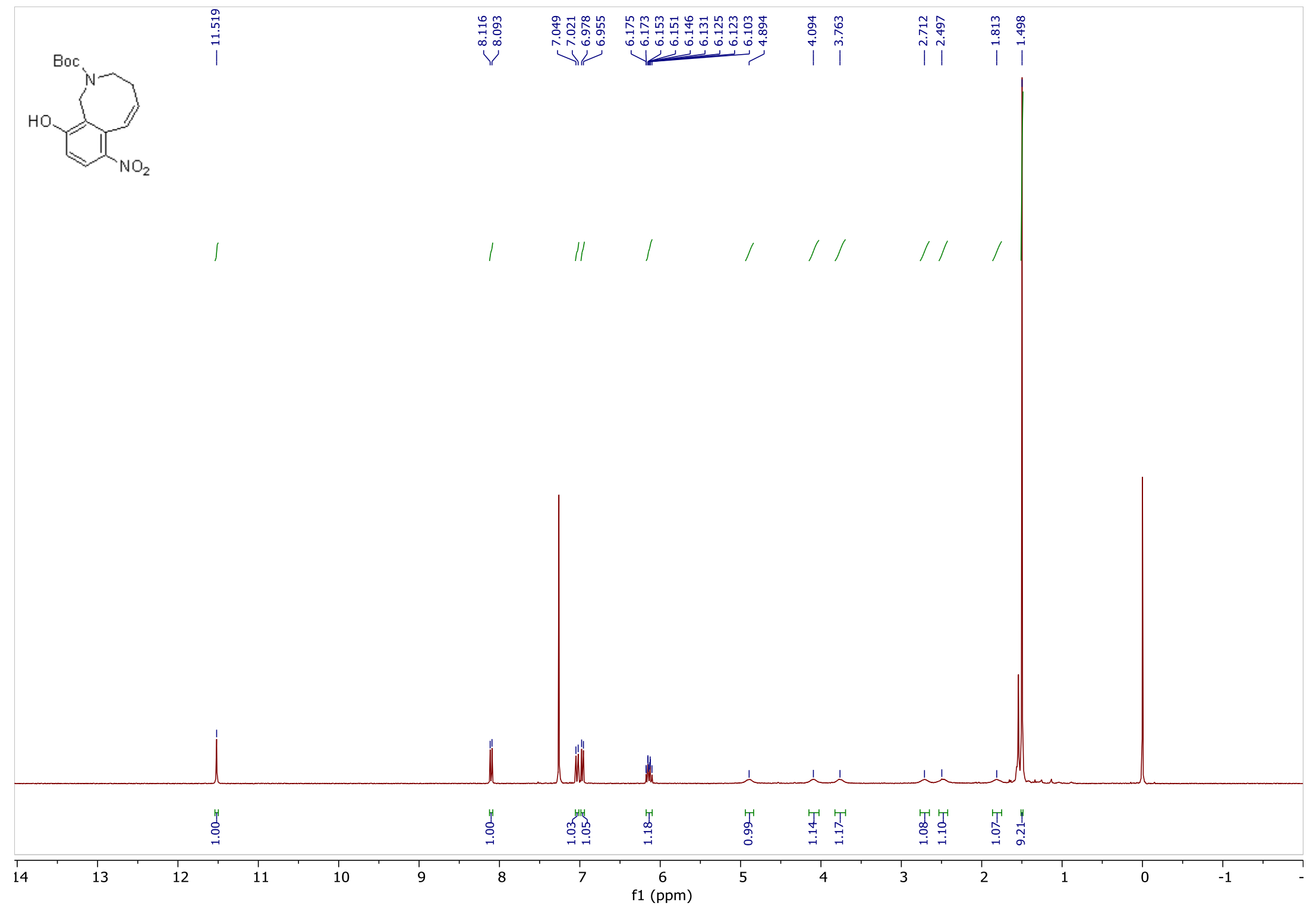

Figure 21: ${ }^{1} \mathrm{H}$ NMR of Compound 104 

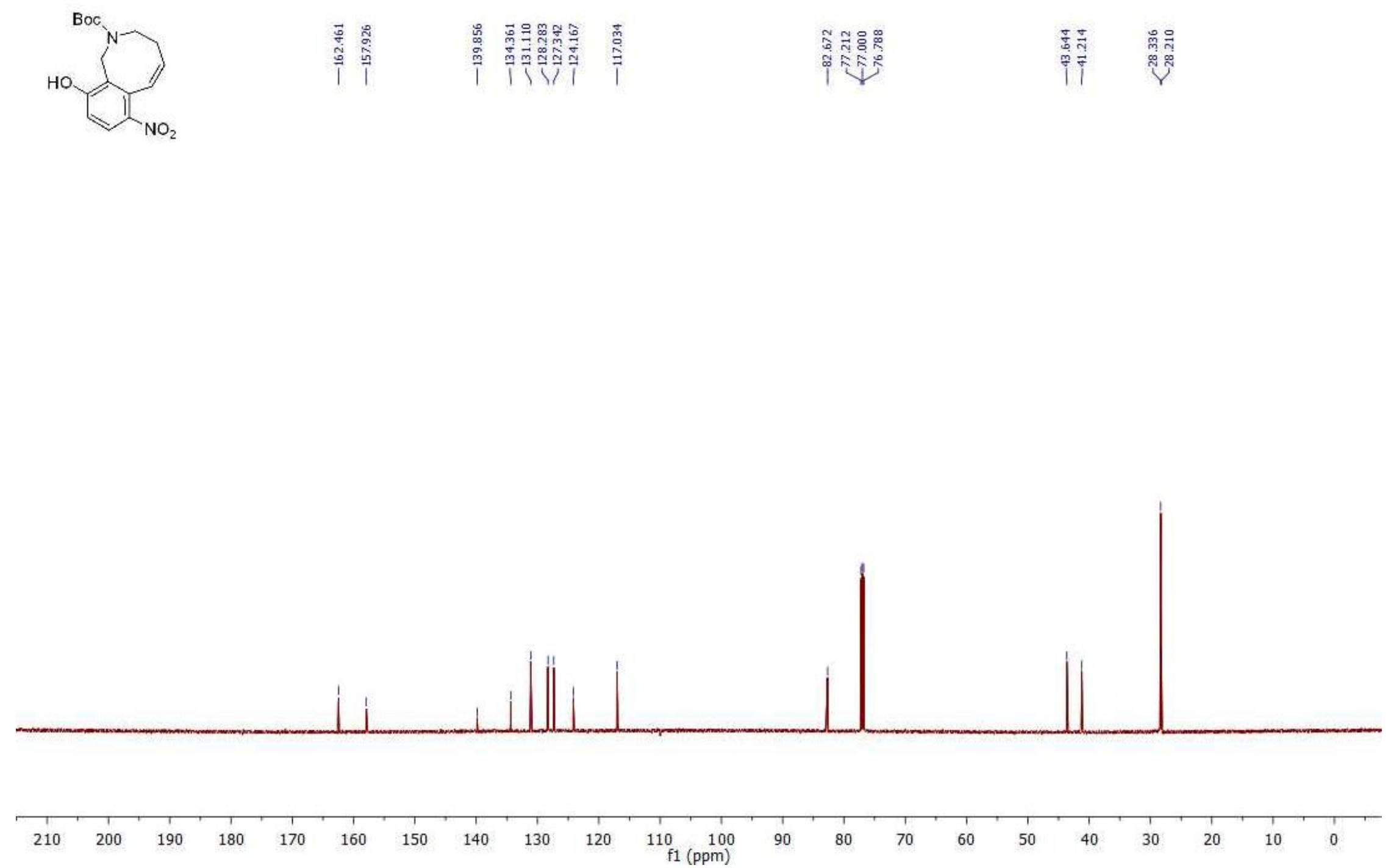

Figure 22: ${ }^{13} \mathrm{C}$ NMR of Compound 104 

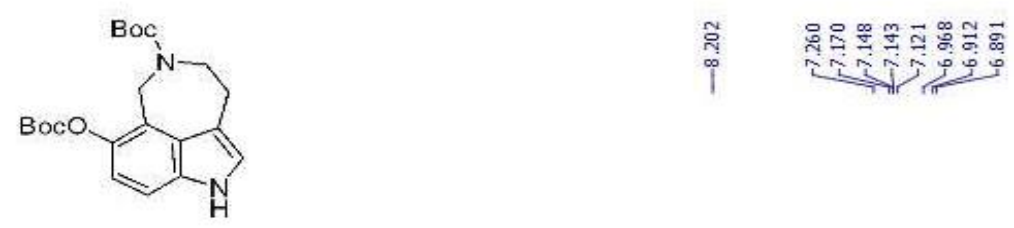

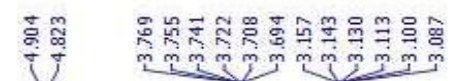

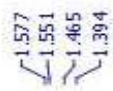

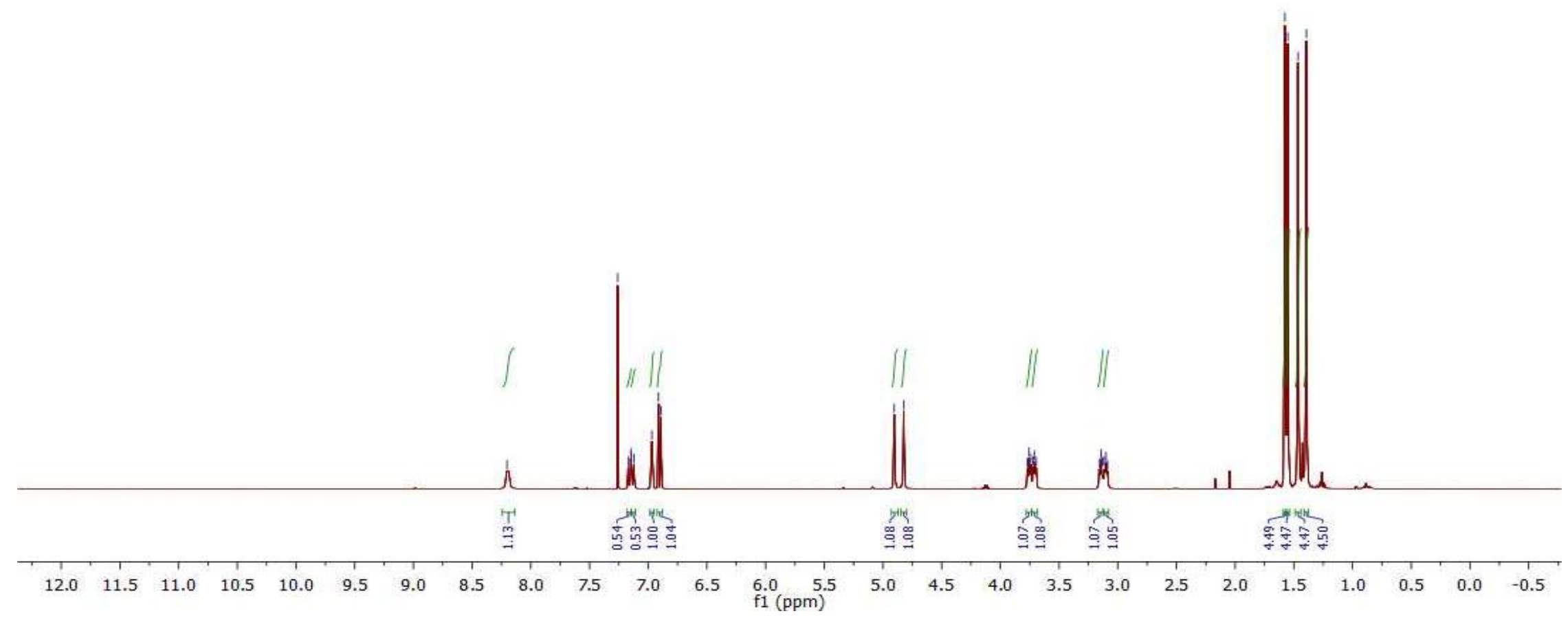

Figure 23: ${ }^{1} \mathrm{H}$ NMR of Compound $\mathbf{1 0 5}$ 

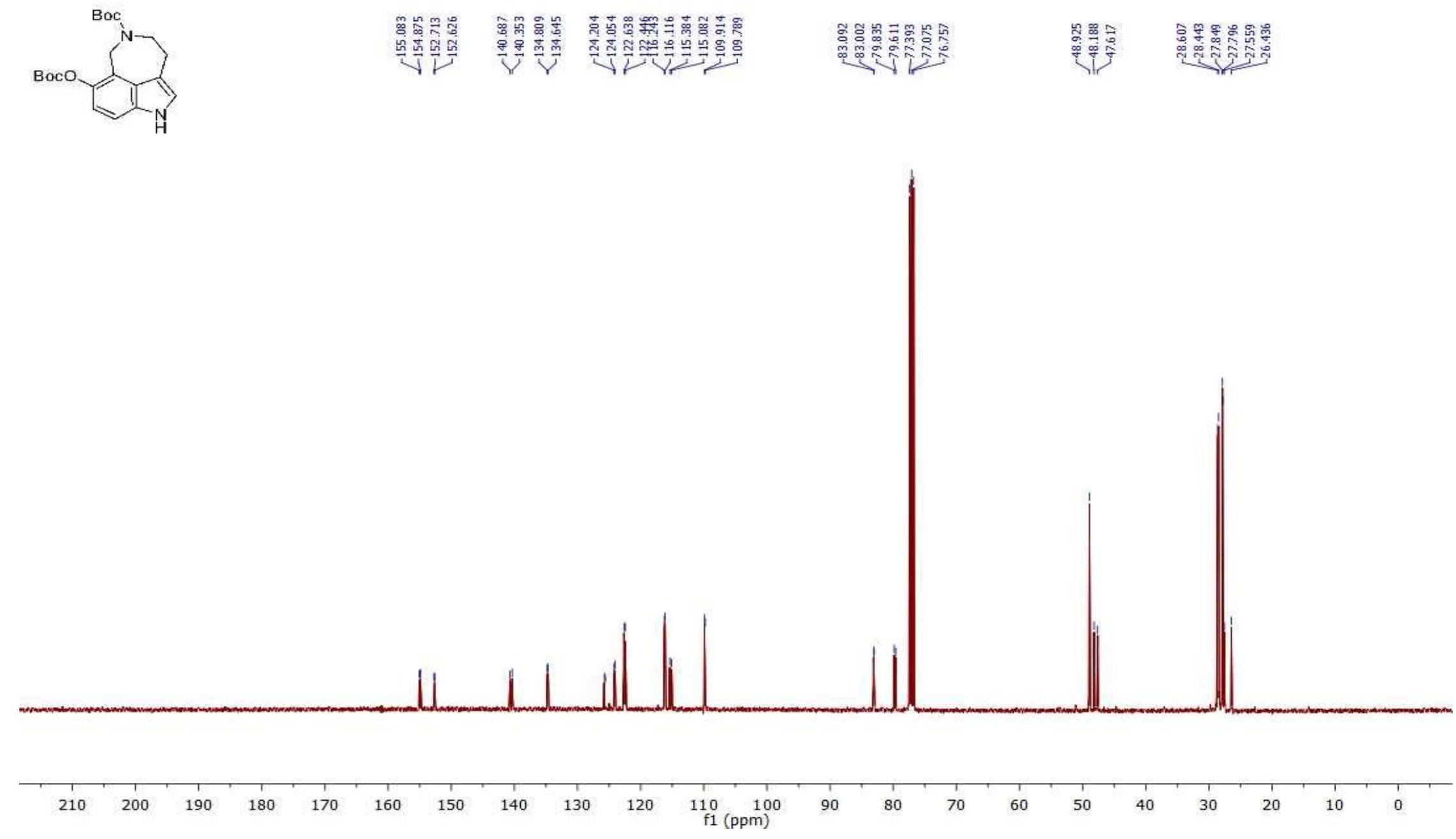

Figure 24: ${ }^{13} \mathrm{C}$ NMR of Compound 105 


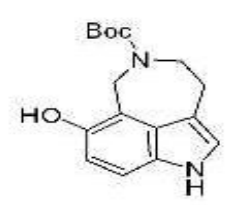

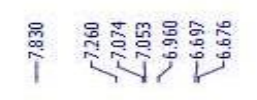

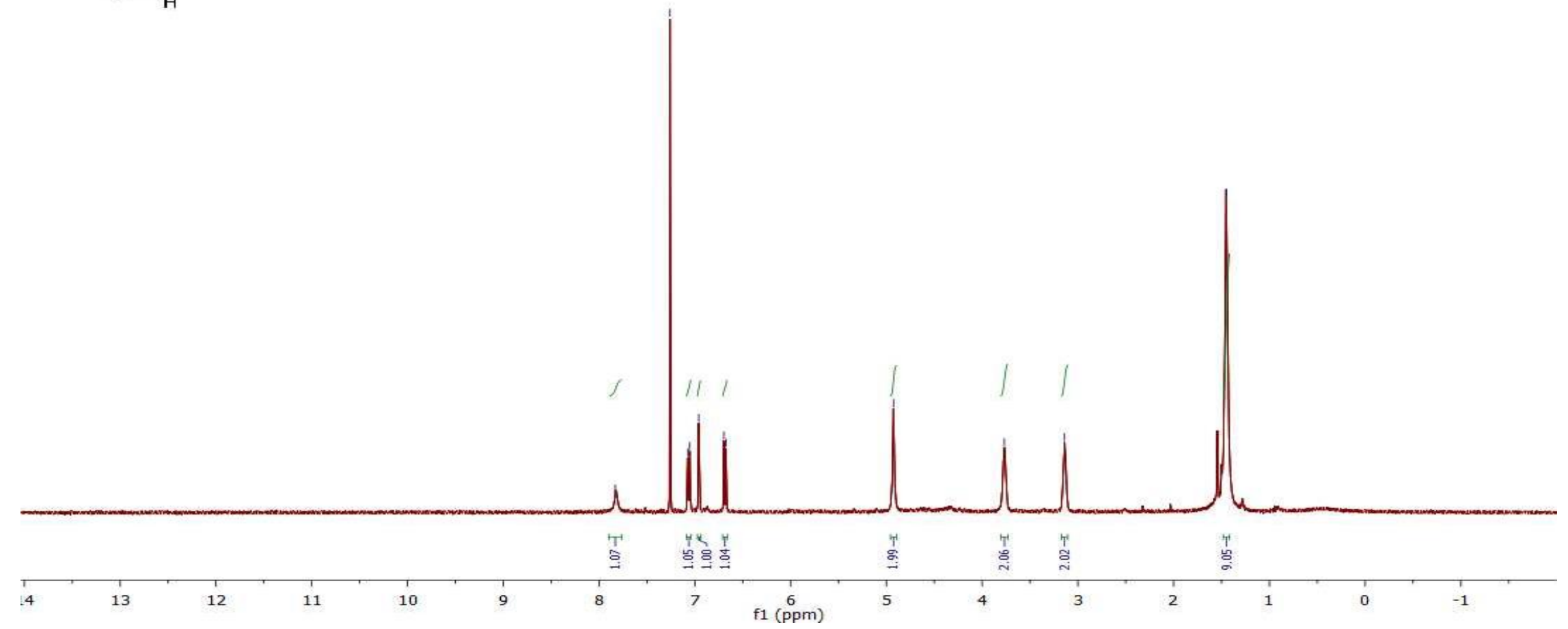

Figure 25: ${ }^{1} \mathrm{H}$ NMR of Compound 106 $\stackrel{2}{i}$

$\stackrel{\circ}{i}$

商

$\stackrel{i}{i}$

107 

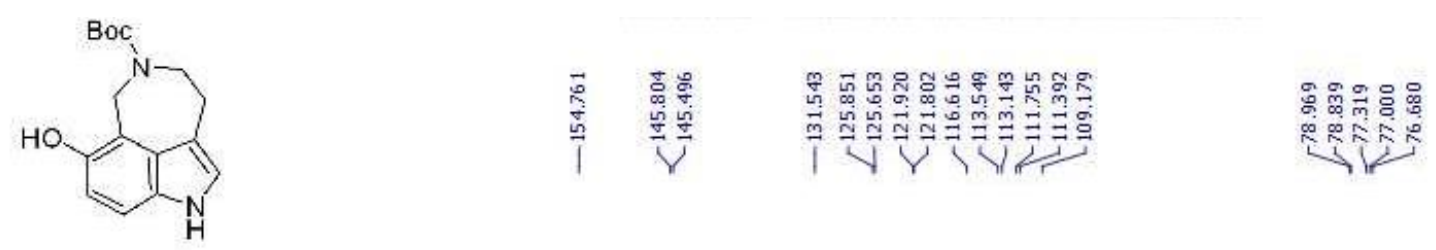

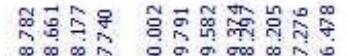

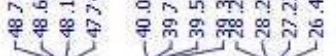

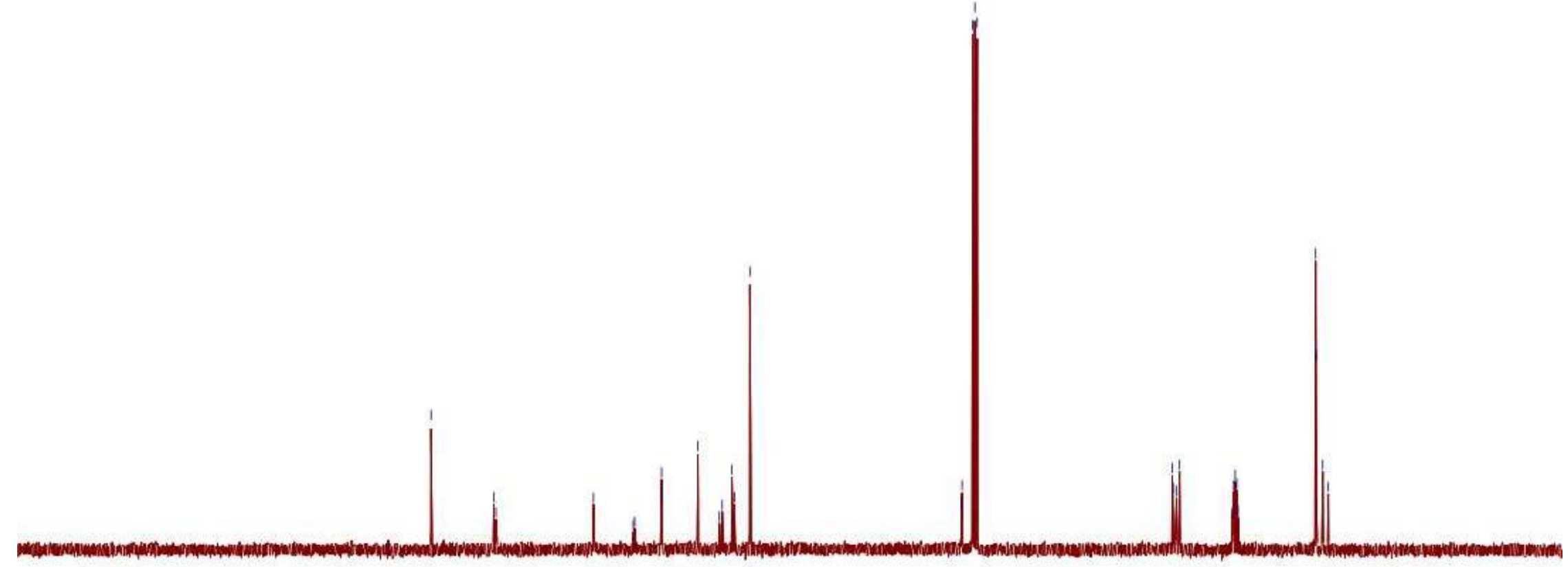

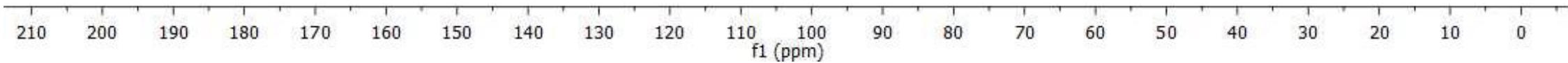

Figure 26: ${ }^{13} \mathrm{C}$ NMR of Compound 106 


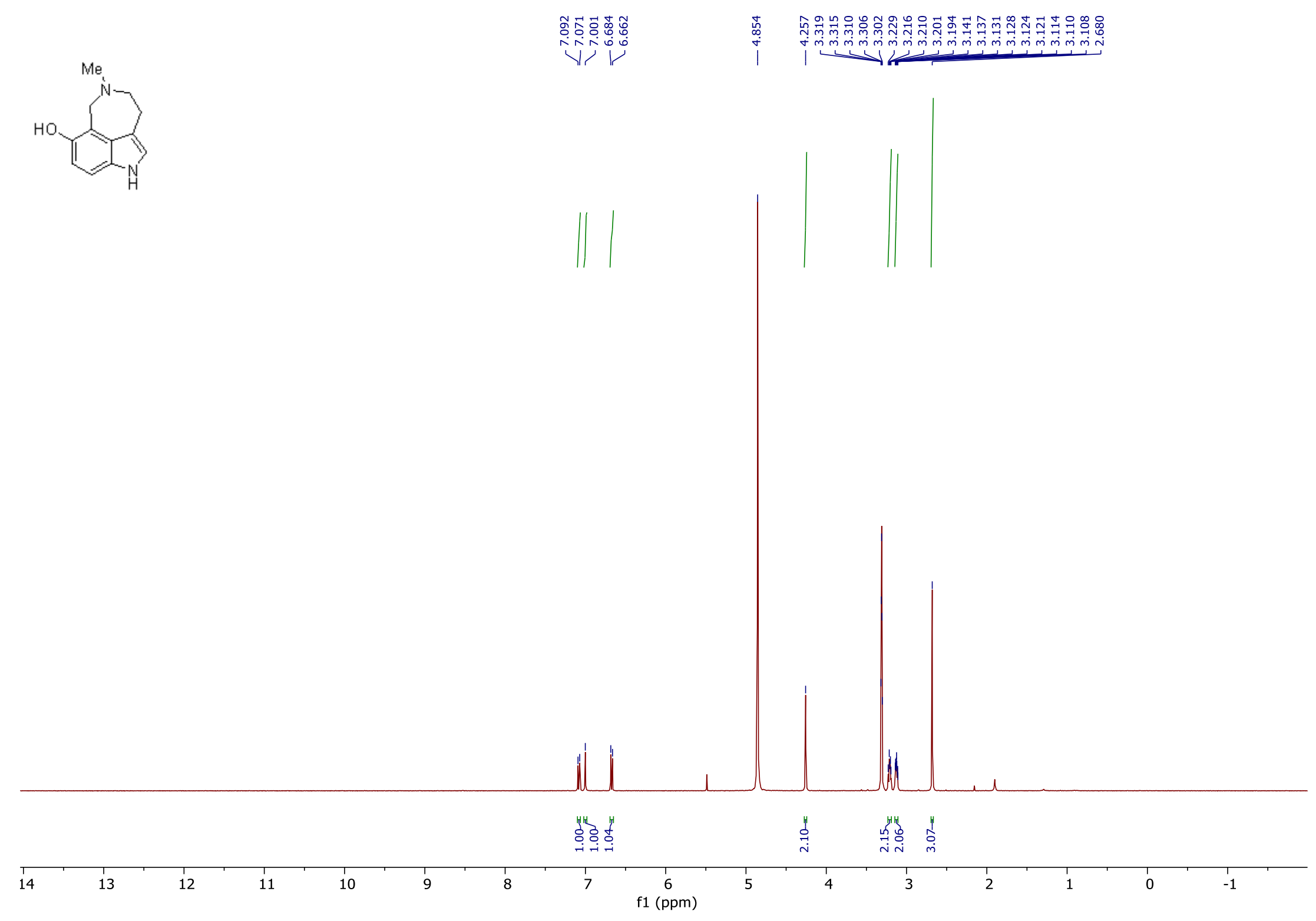

Figure 27: ${ }^{1} \mathrm{H}$ NMR of Compound 88 

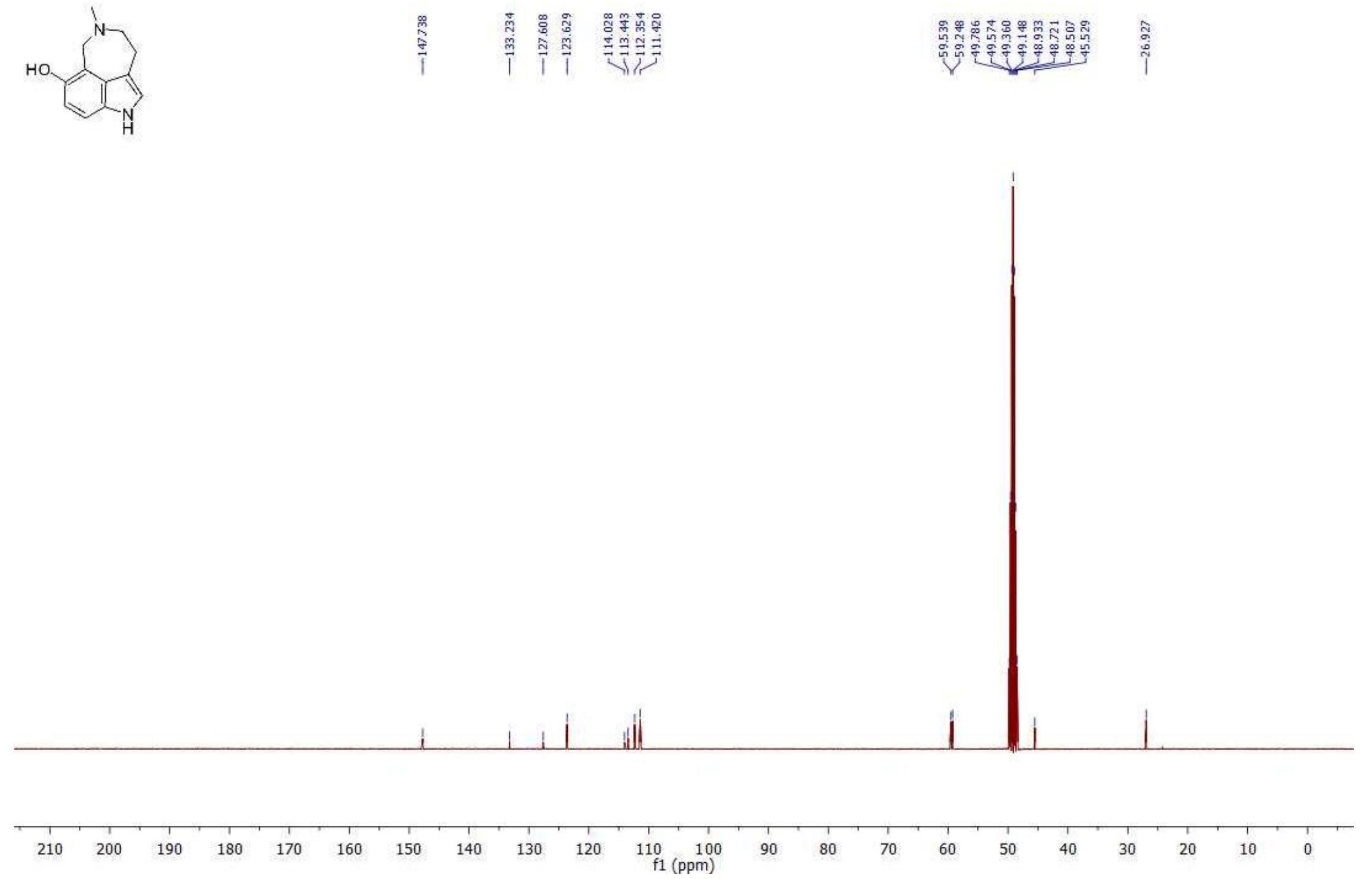

Figure 28: ${ }^{13} \mathrm{C}$ NMR of Compound 88 


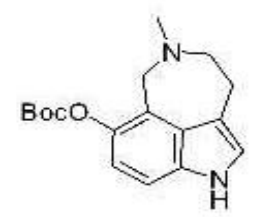

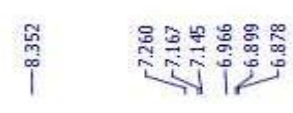

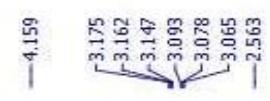

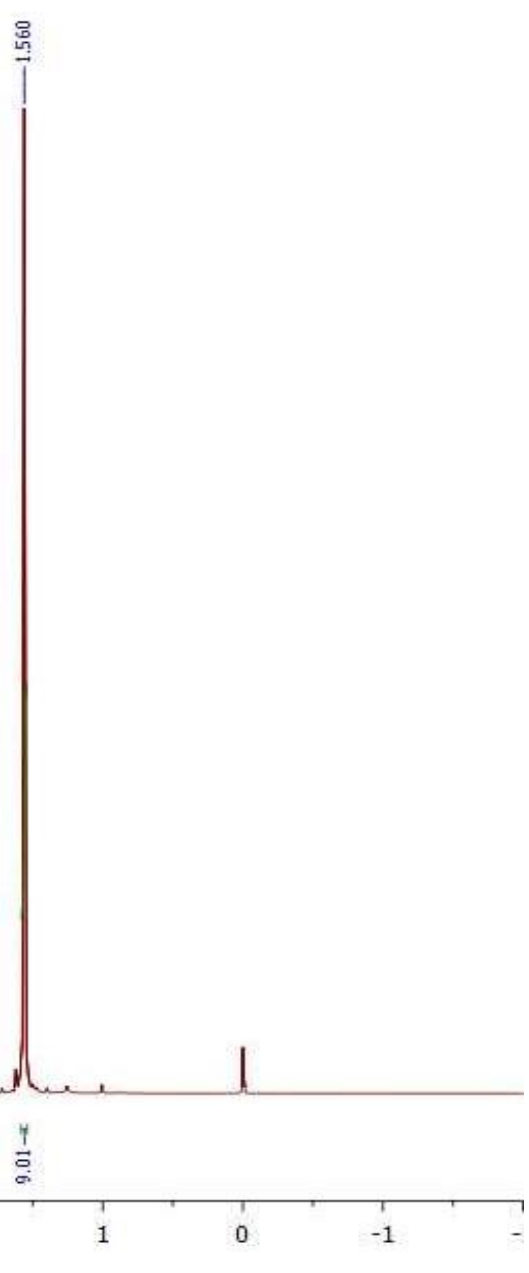

Figure 29: ${ }^{1} \mathrm{H}$ NMR of Compound 107

111 

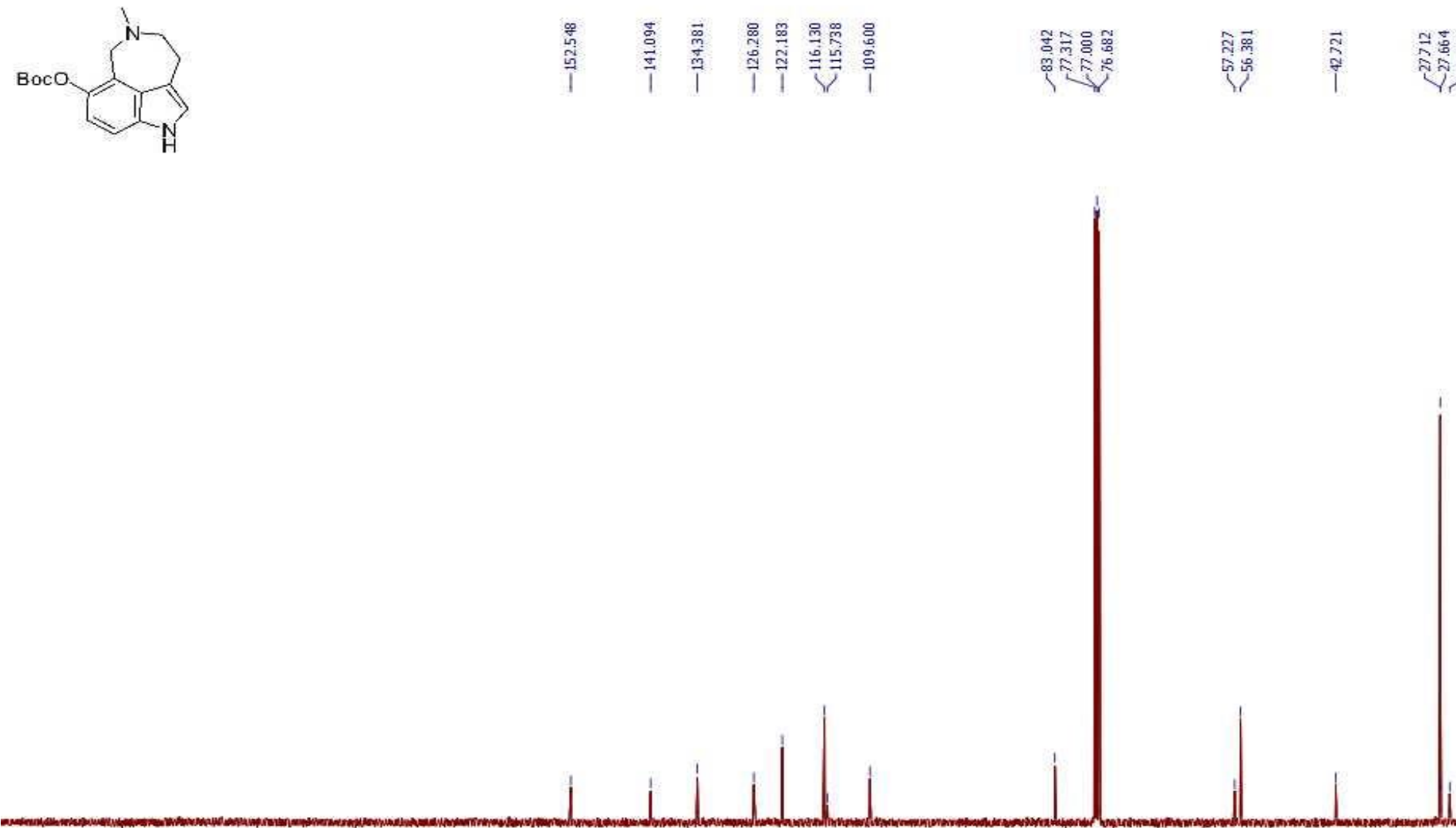

$\begin{array}{llll}230 & 220 & 210 & 200\end{array}$

$160 \quad 150 \quad 140$

130

$120 \stackrel{110}{110} 100$

70

605
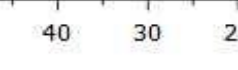

Figure 30: ${ }^{13} \mathrm{C}$ NMR of Compound 107 
${ }^{1} \mathrm{H}$ and ${ }^{13} \mathrm{C}$ NMR for Chapter 3: Hyrtioreticulins C \& D

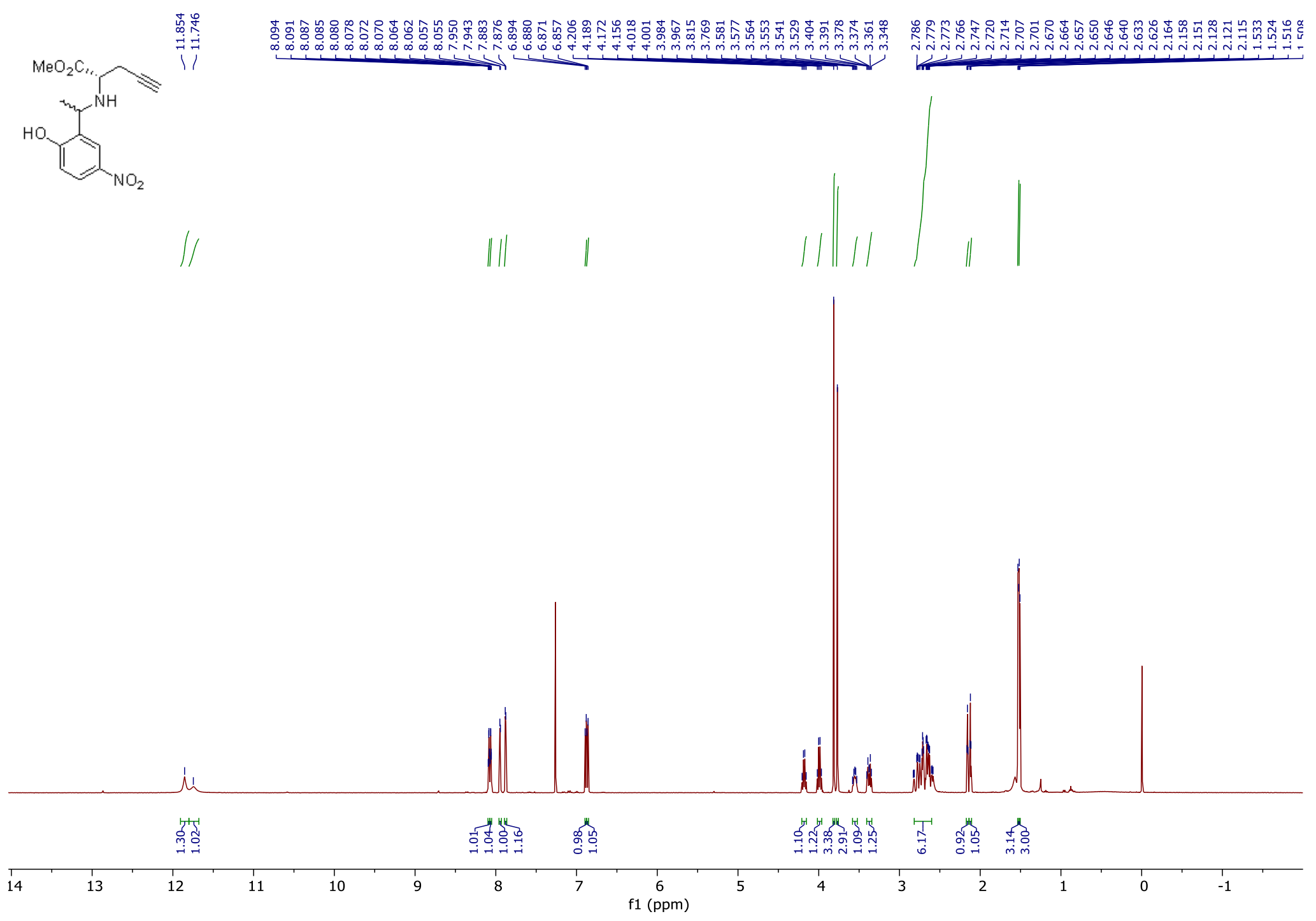

Figure 31: ${ }^{1} \mathrm{H}$ NMR of Compound 127 

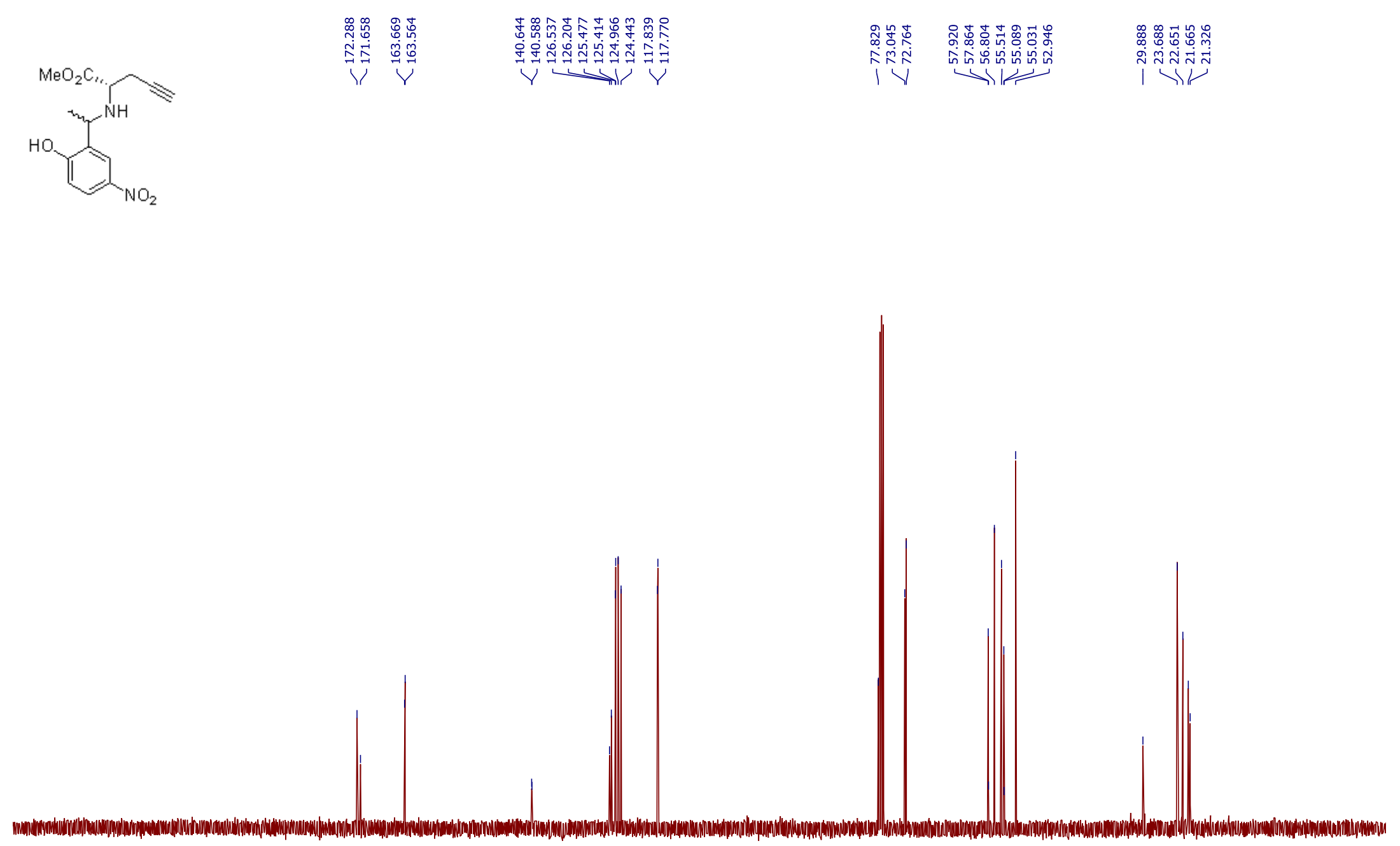

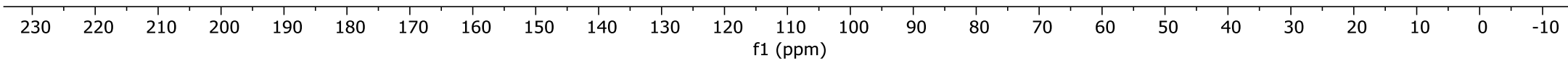

Figure 32: ${ }^{13} \mathrm{C}$ NMR of Compound 127 

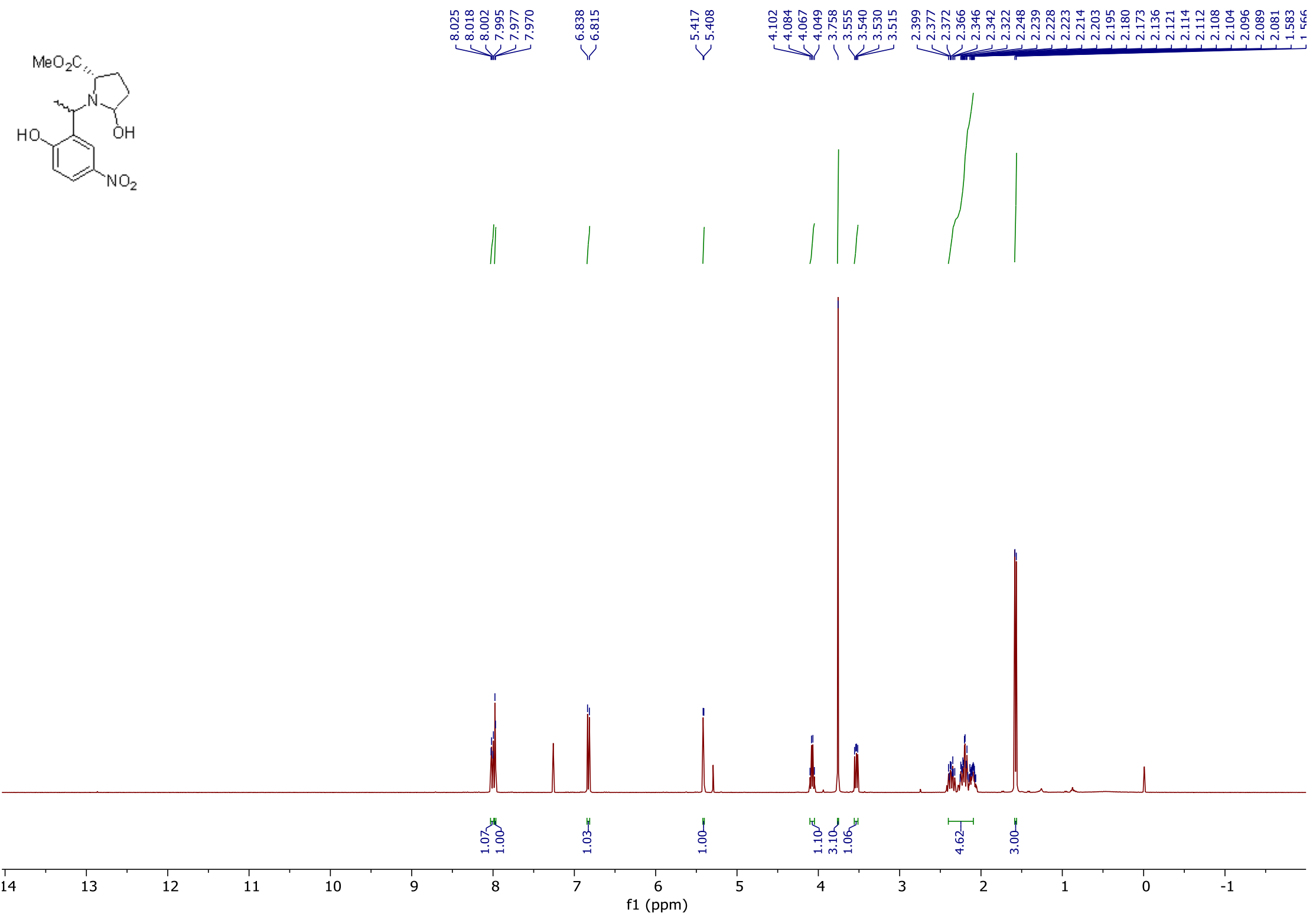

Figure 33: ${ }^{1} \mathrm{H}$ NMR of Compound 128 

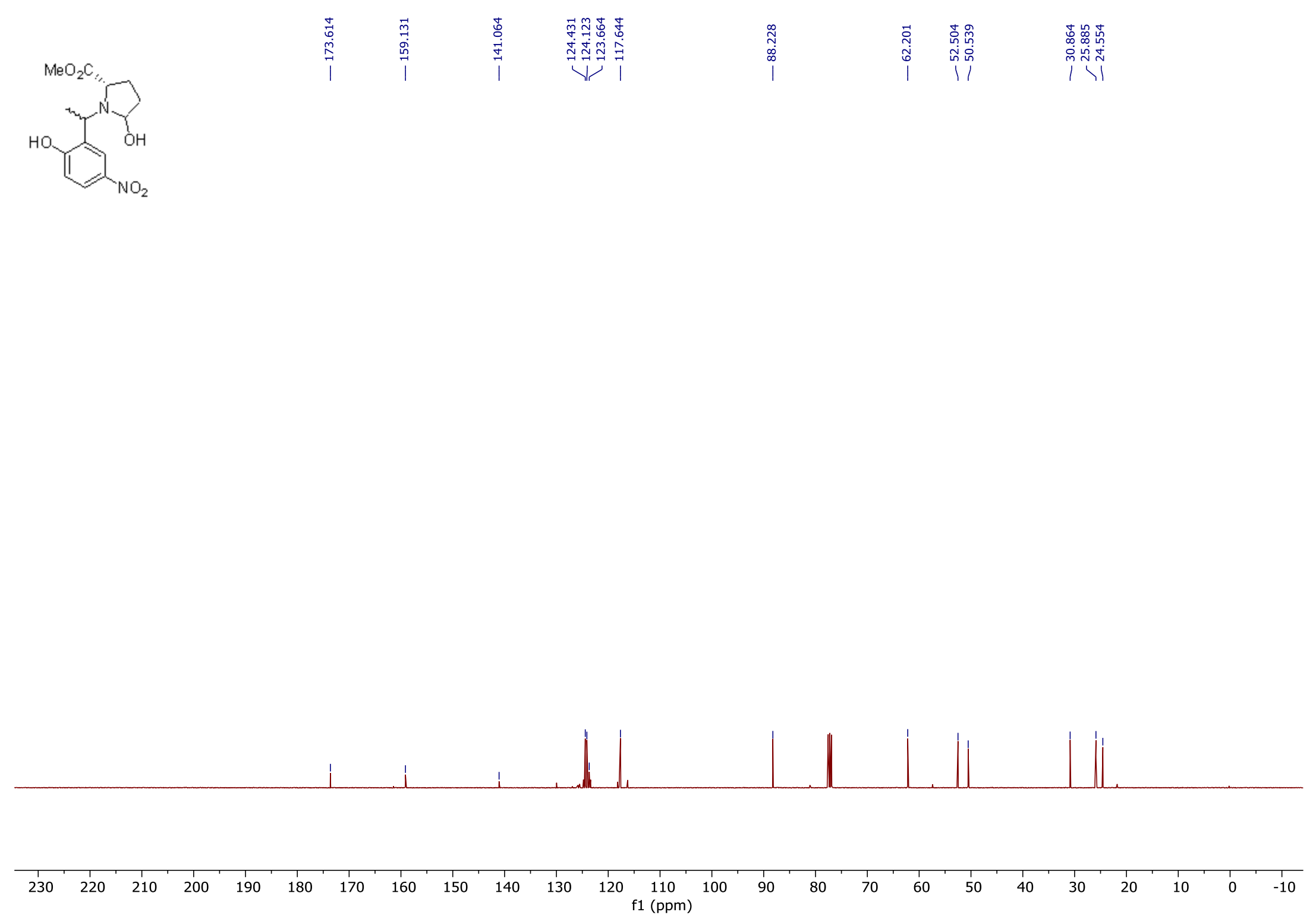

Figure $34:{ }^{13} \mathrm{C}$ NMR of Compound 128 


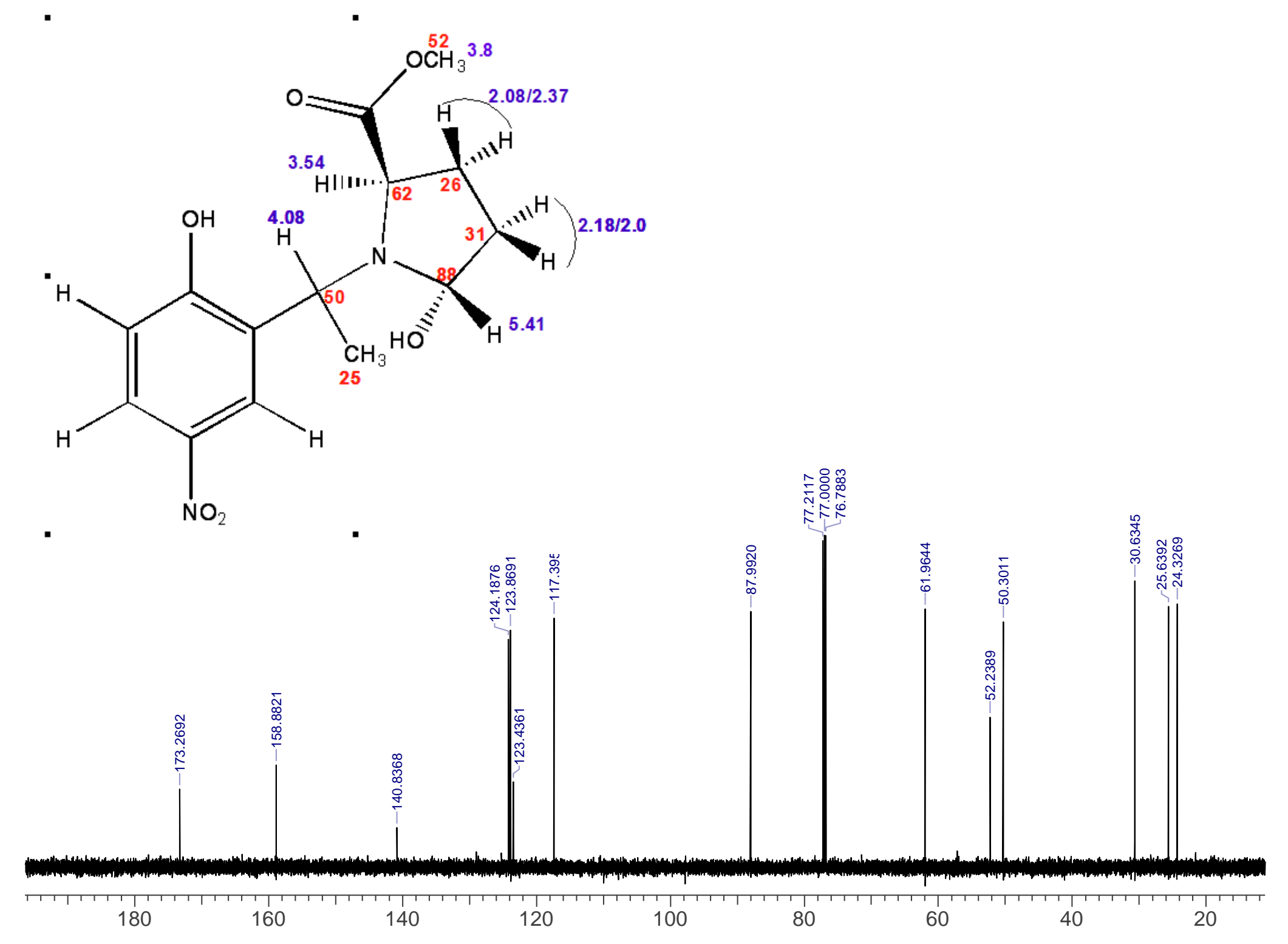

Figure 35: ${ }^{13} \mathrm{C}$ NMR of Compound $\mathbf{1 2 8}$ 


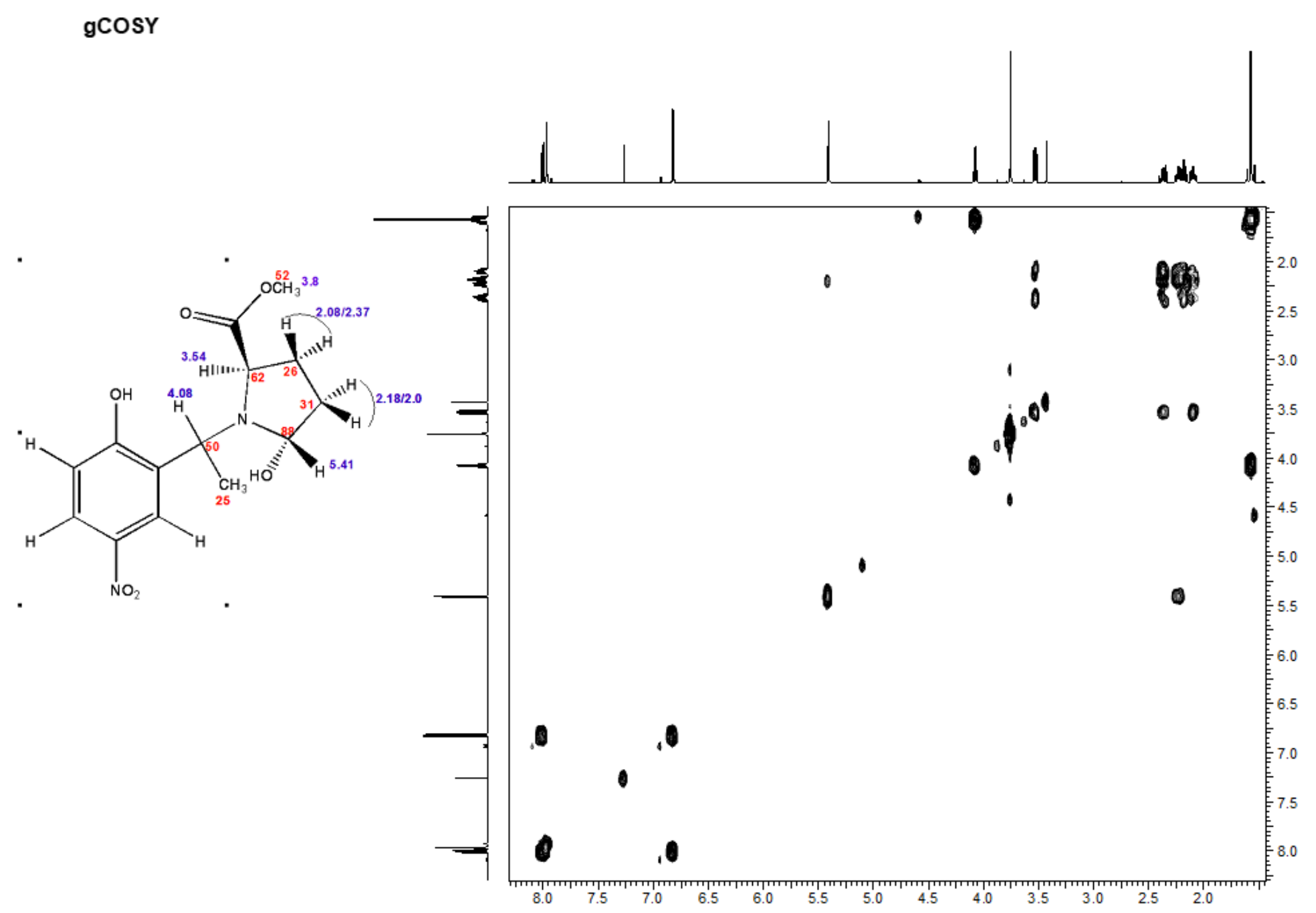

Figure 36: COSY of Compound 128 

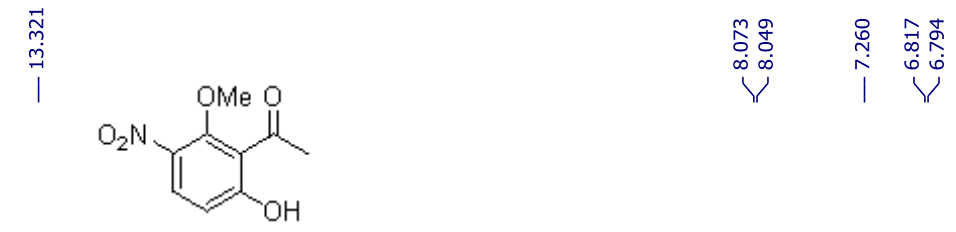

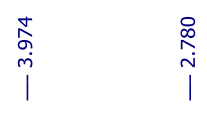

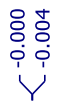

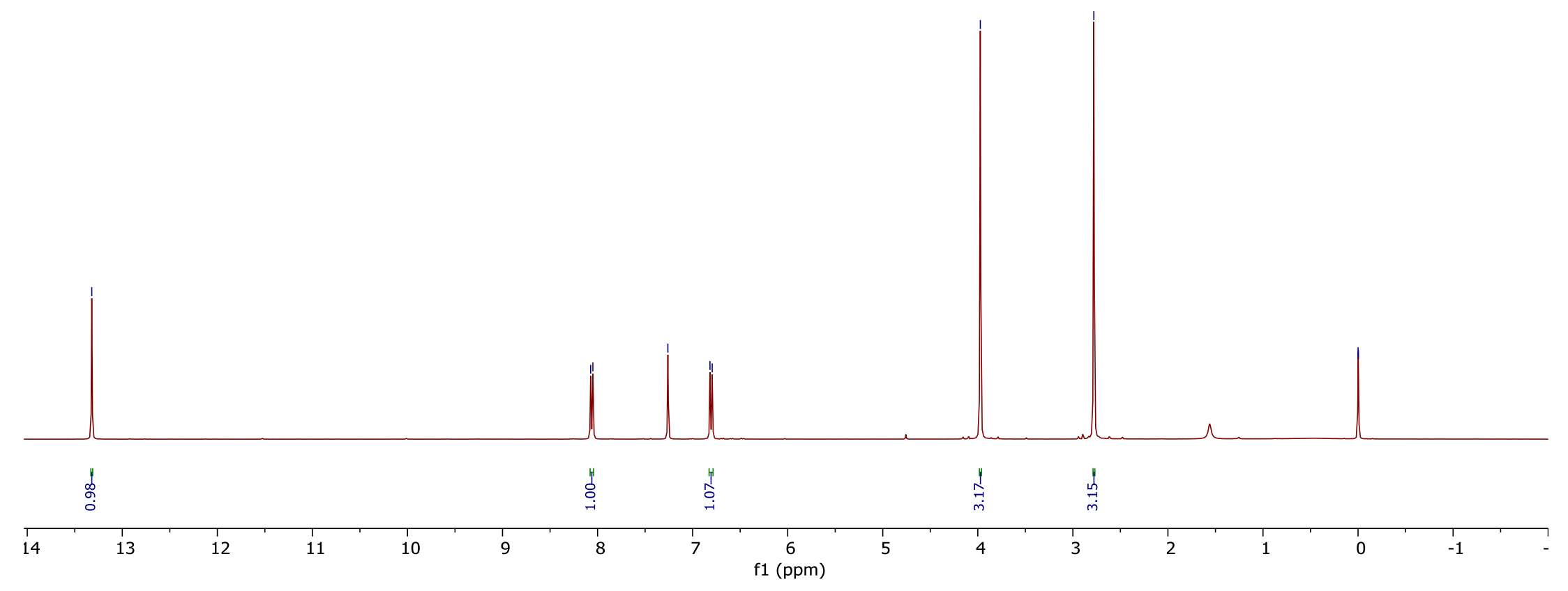

Figure 37: ${ }^{1} \mathrm{H}$ NMR of Compound 136 


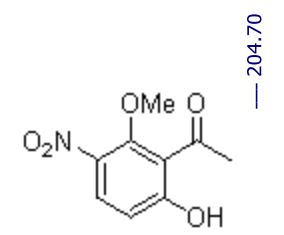

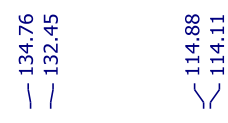

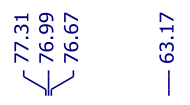

$\underset{\substack{\tilde{m} \\ \tilde{m}}}{\tilde{N}}$

$\stackrel{\text { iे }}{i}$

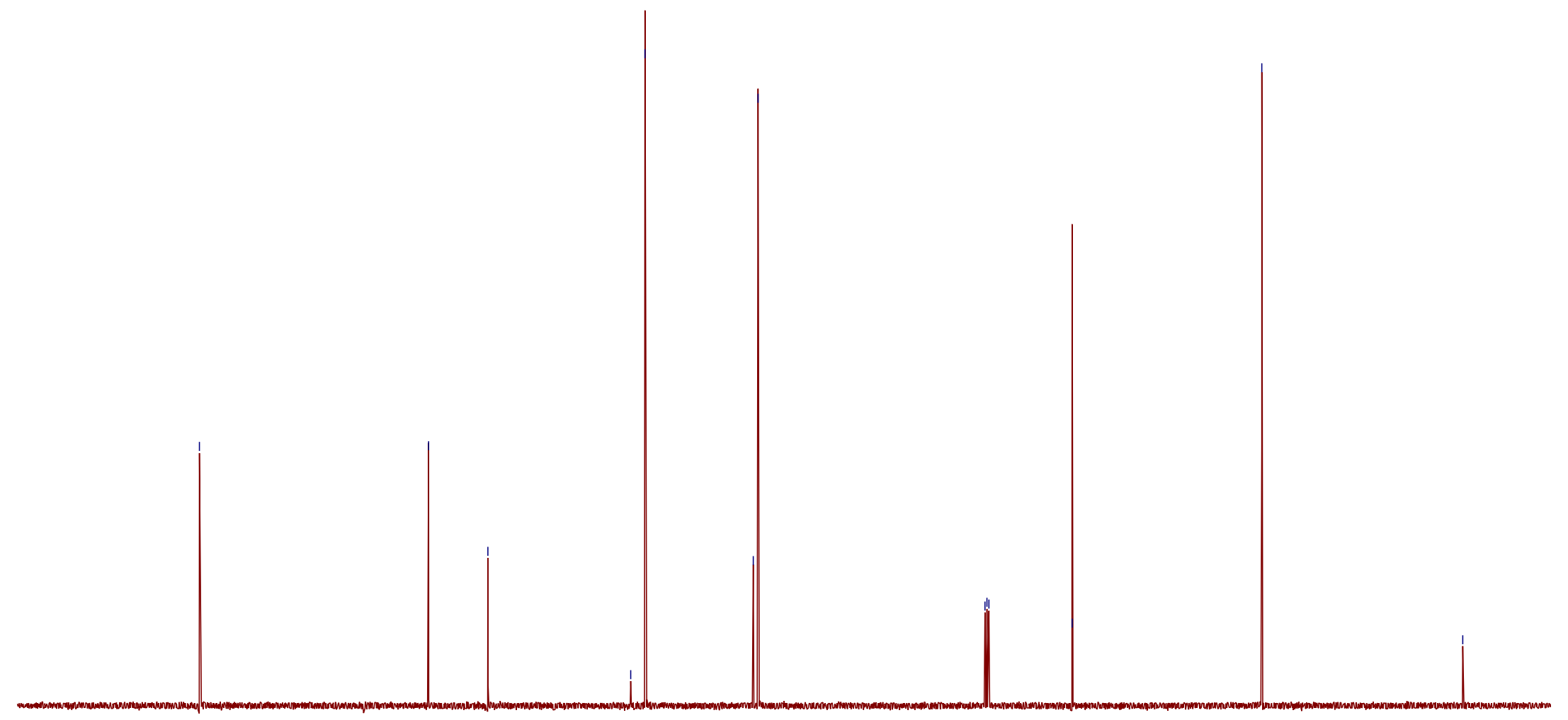

\begin{tabular}{lllllllllllllllllllllllll}
1 & 1 \\
\hline 230 & 220 & 210 & 200 & 190 & 180 & 170 & 160 & 150 & 140 & 130 & 120 & 110 & 100 & 90 & 80 & 70 & 60 & 50 & 40 & 30 & 20 & 10 & 0 & -10
\end{tabular}

Figure 38: ${ }^{13} \mathrm{C}$ NMR of Compound 136 

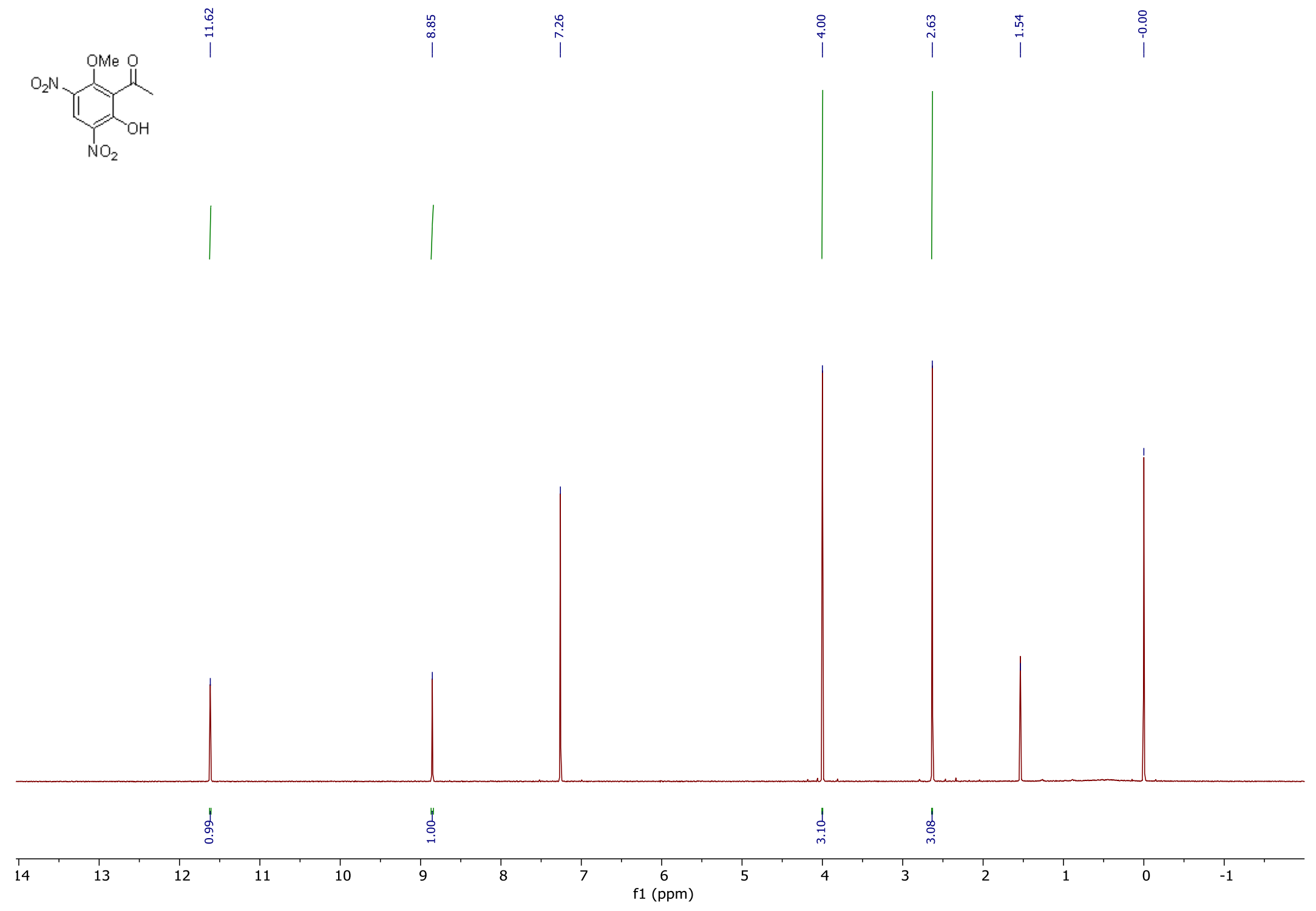

Figure 39: ${ }^{1} \mathrm{H}$ NMR of Compound 137 

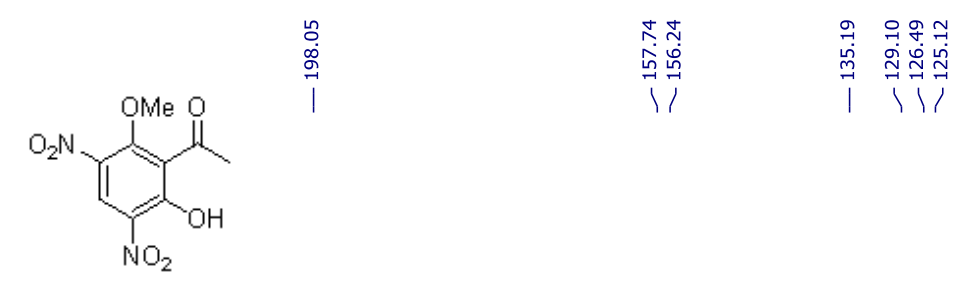

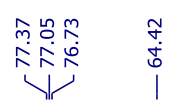

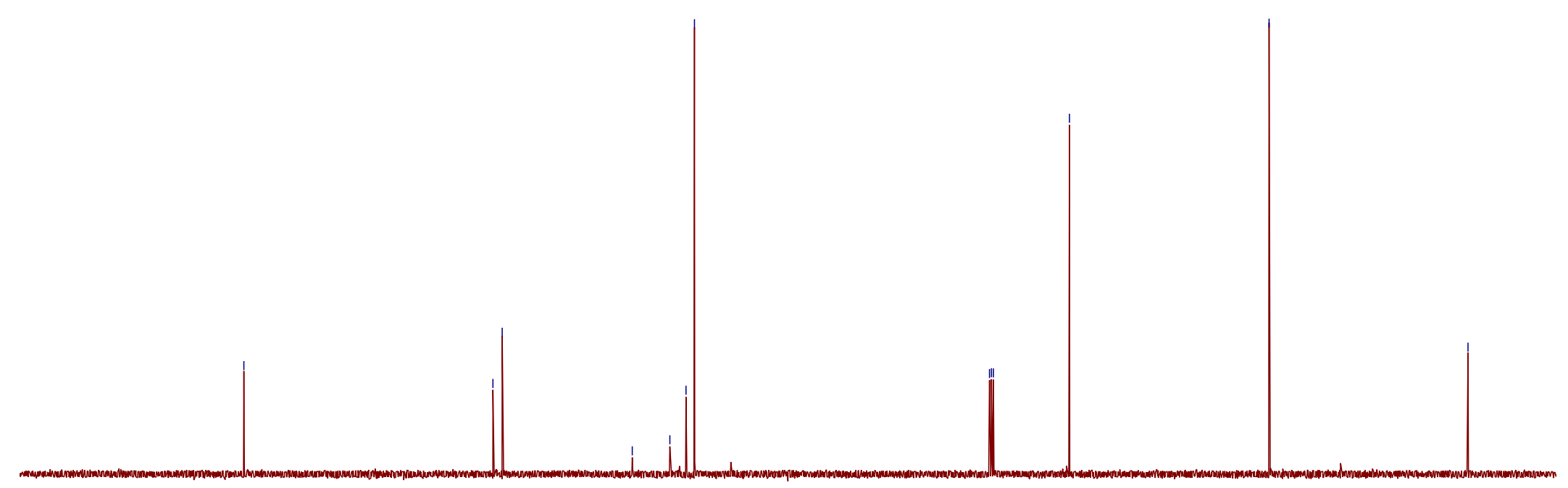

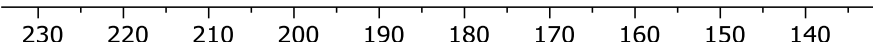

$120 \quad 110 \quad 100 \quad 90$ f1 (ppm)

Figure 40: ${ }^{13} \mathrm{C}$ NMR of Compound 137 


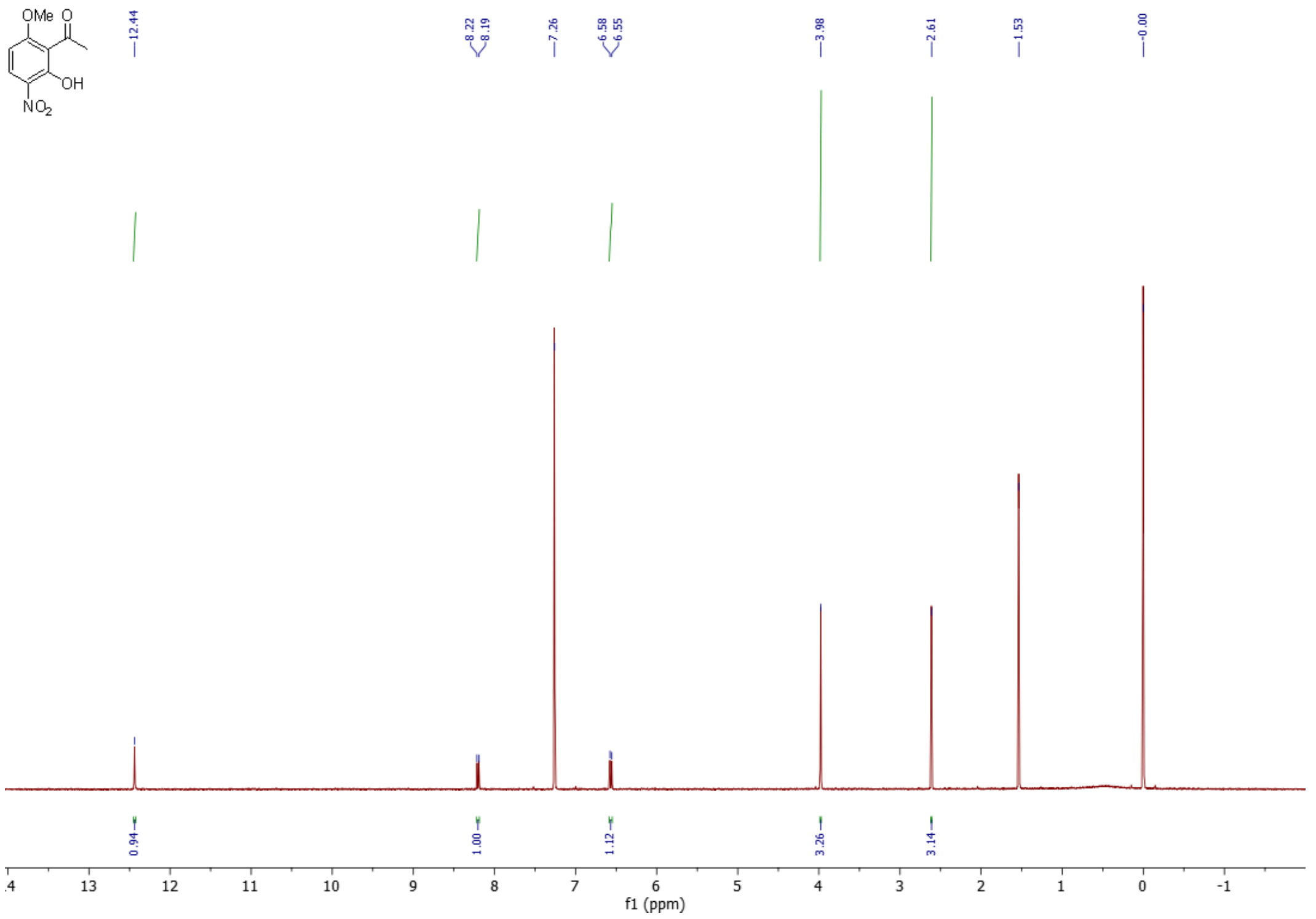

Figure 41: ${ }^{1} \mathrm{H}$ NMR of Compound 138 

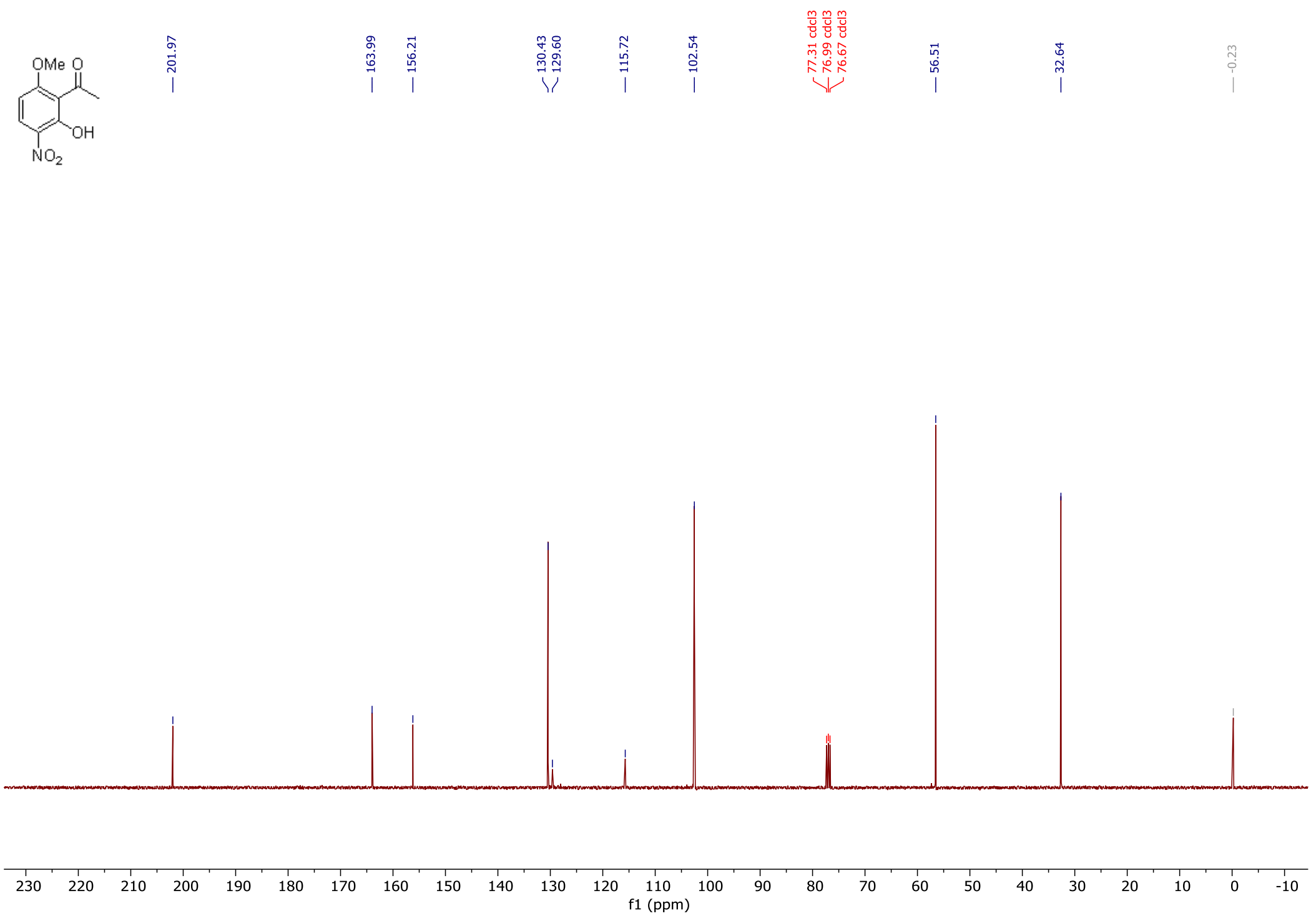

Figure 42: ${ }^{13} \mathrm{C}$ NMR of Compound 138 


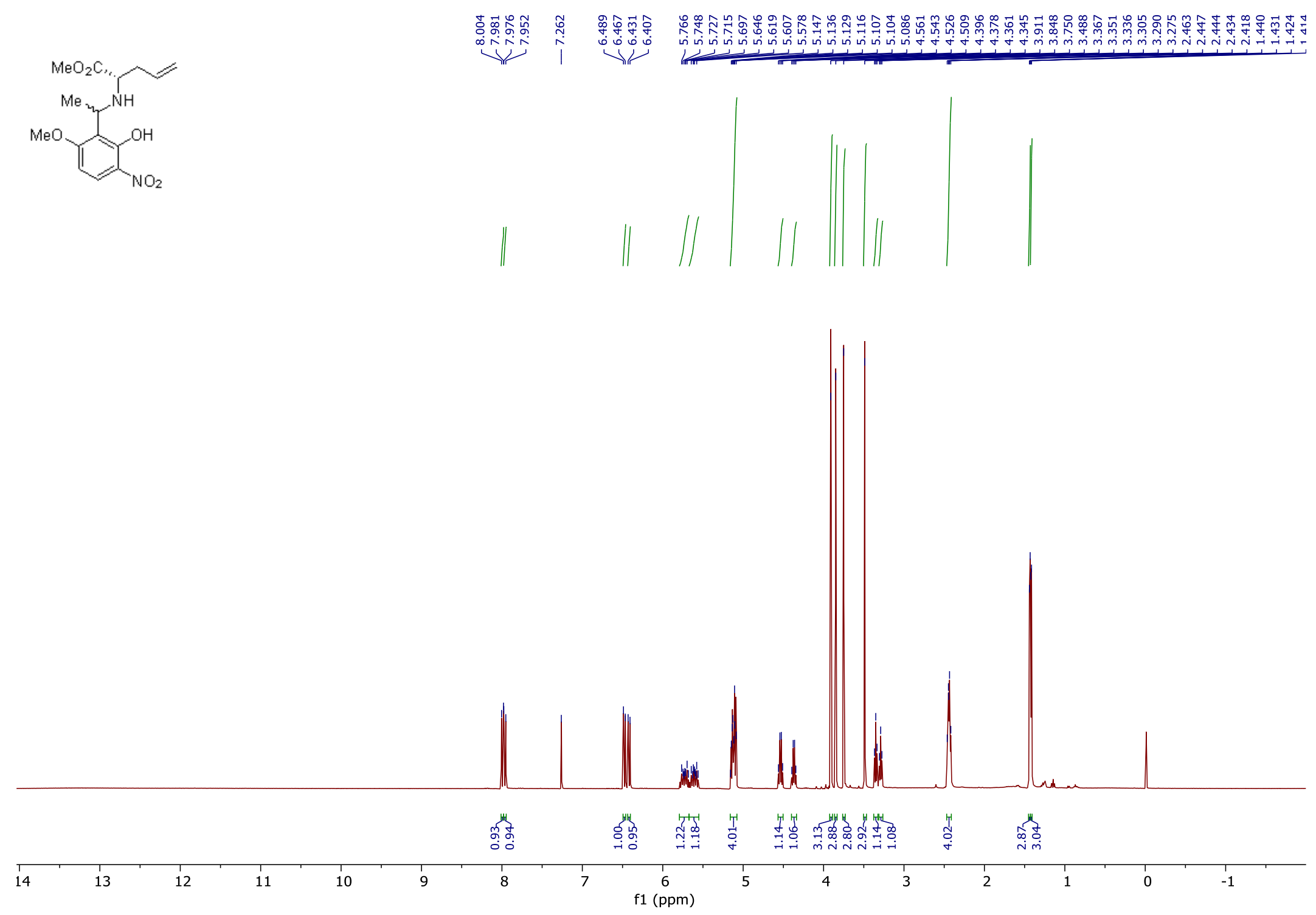

Figure 43: ${ }^{1} \mathrm{H}$ NMR of Compound 140 racemic mixture 

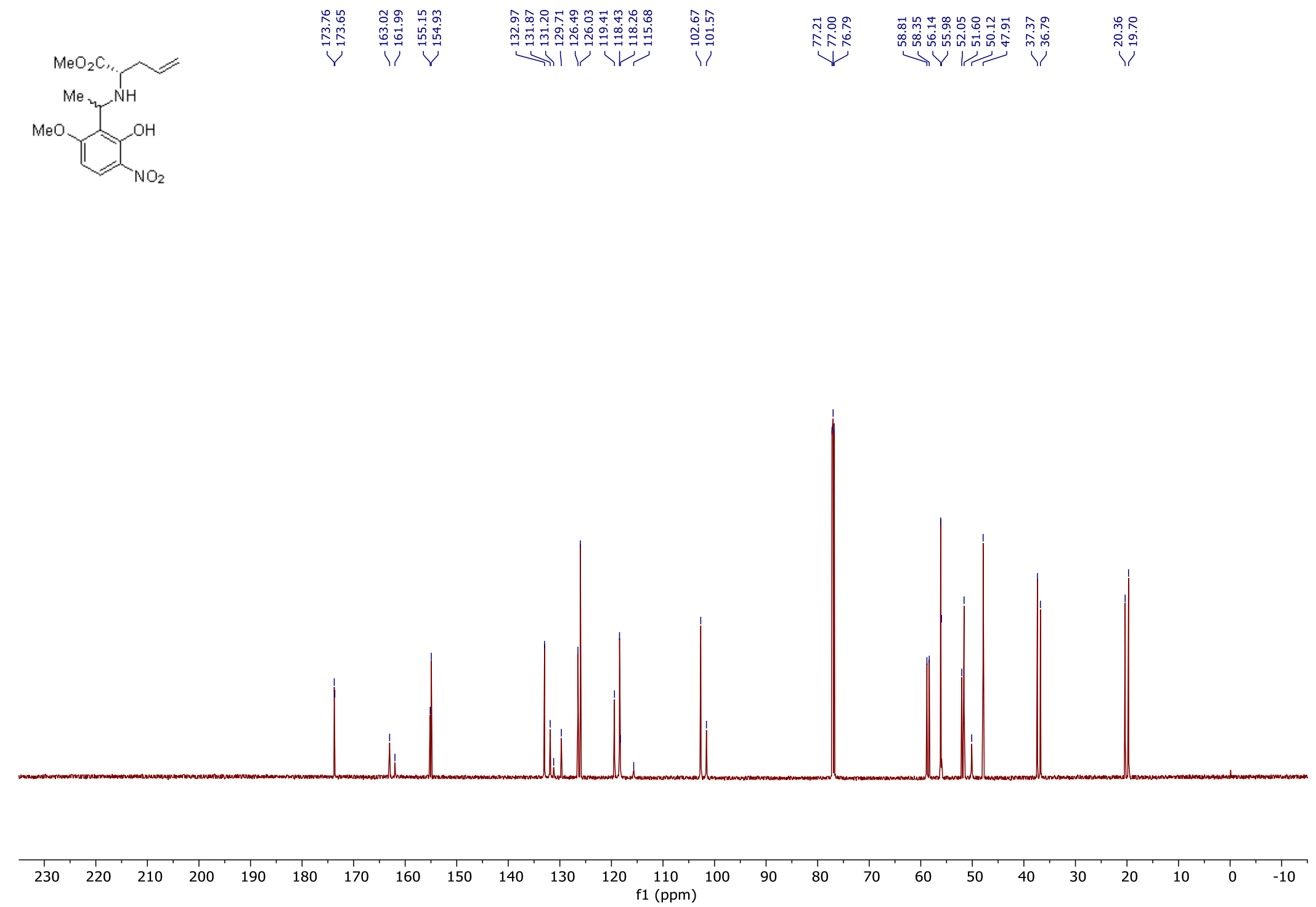

Figure 44: ${ }^{13} \mathrm{C}$ NMR of Compound 140 racemic mixture 


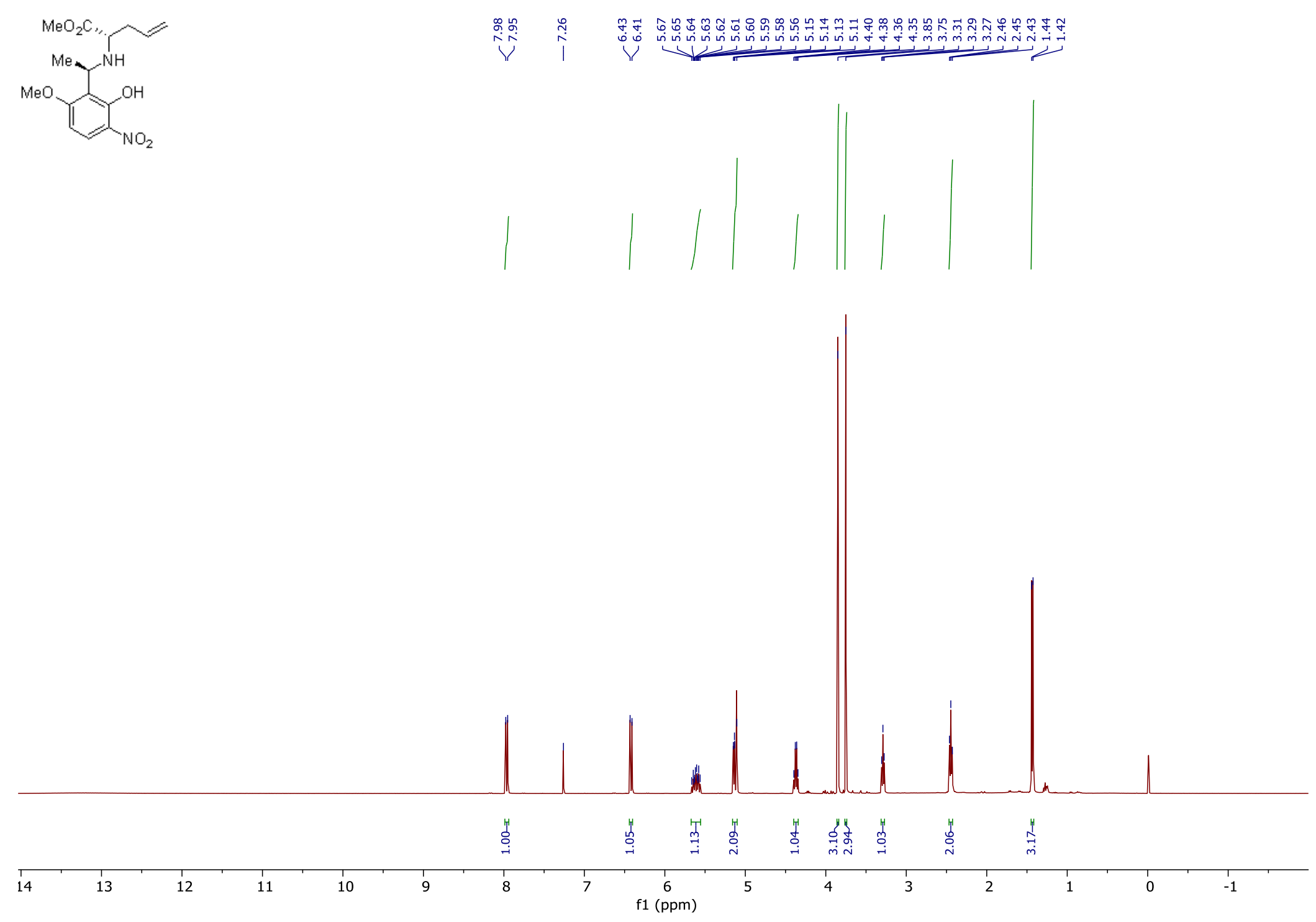

Figure 45: ${ }^{1} \mathrm{H}$ NMR of Compound 140 single isomer 

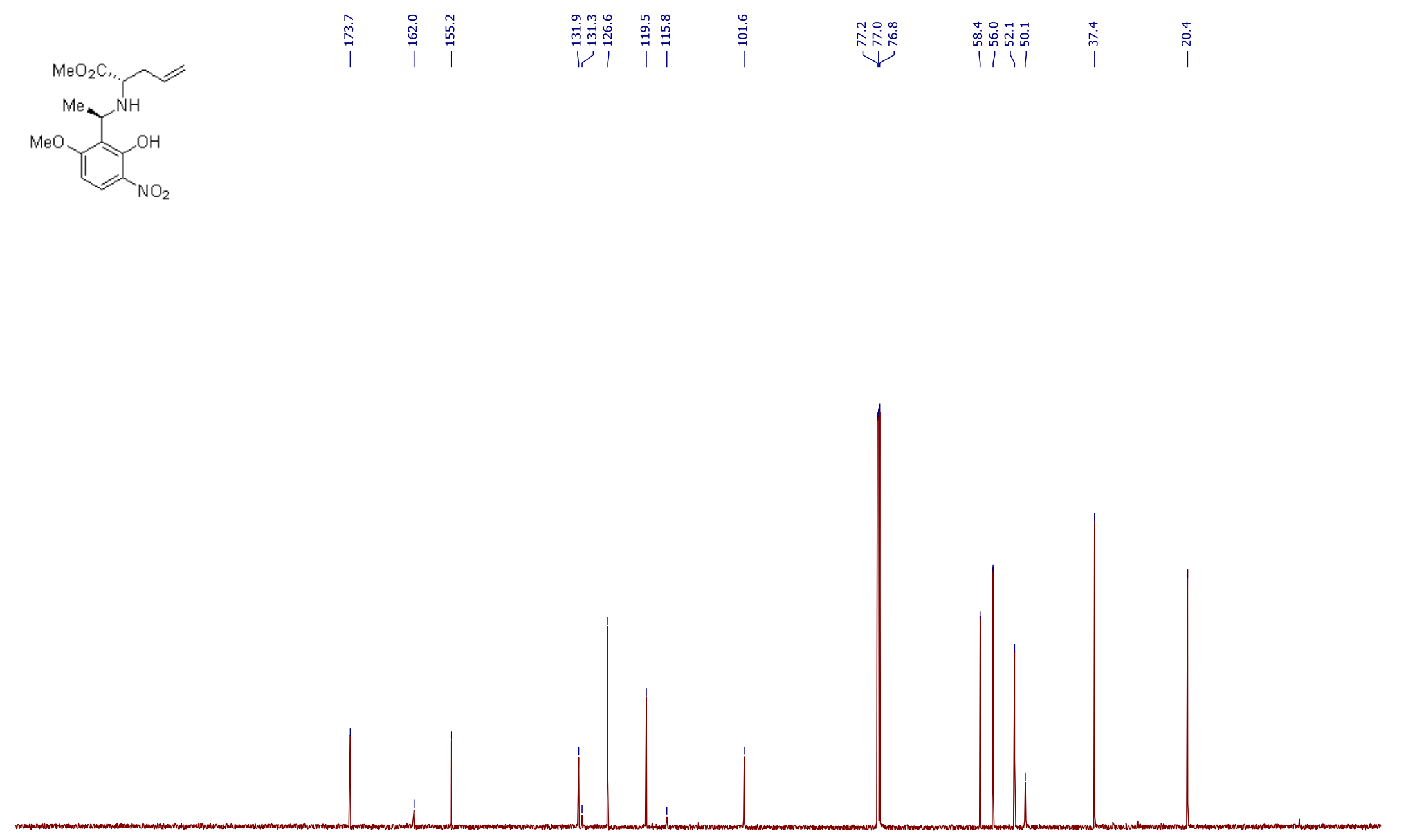

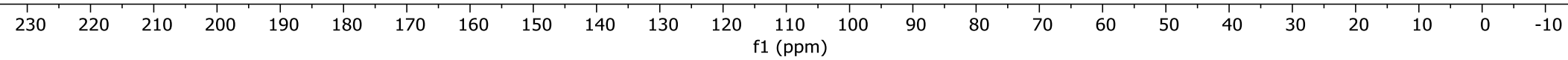

Figure 46: ${ }^{13} \mathrm{C}$ NMR of Compound 140 single isomer 


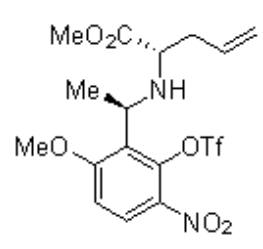

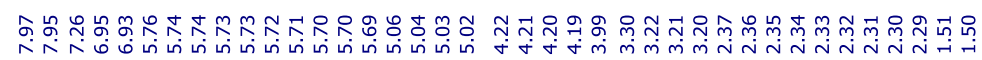

$\checkmark \underbrace{2}$
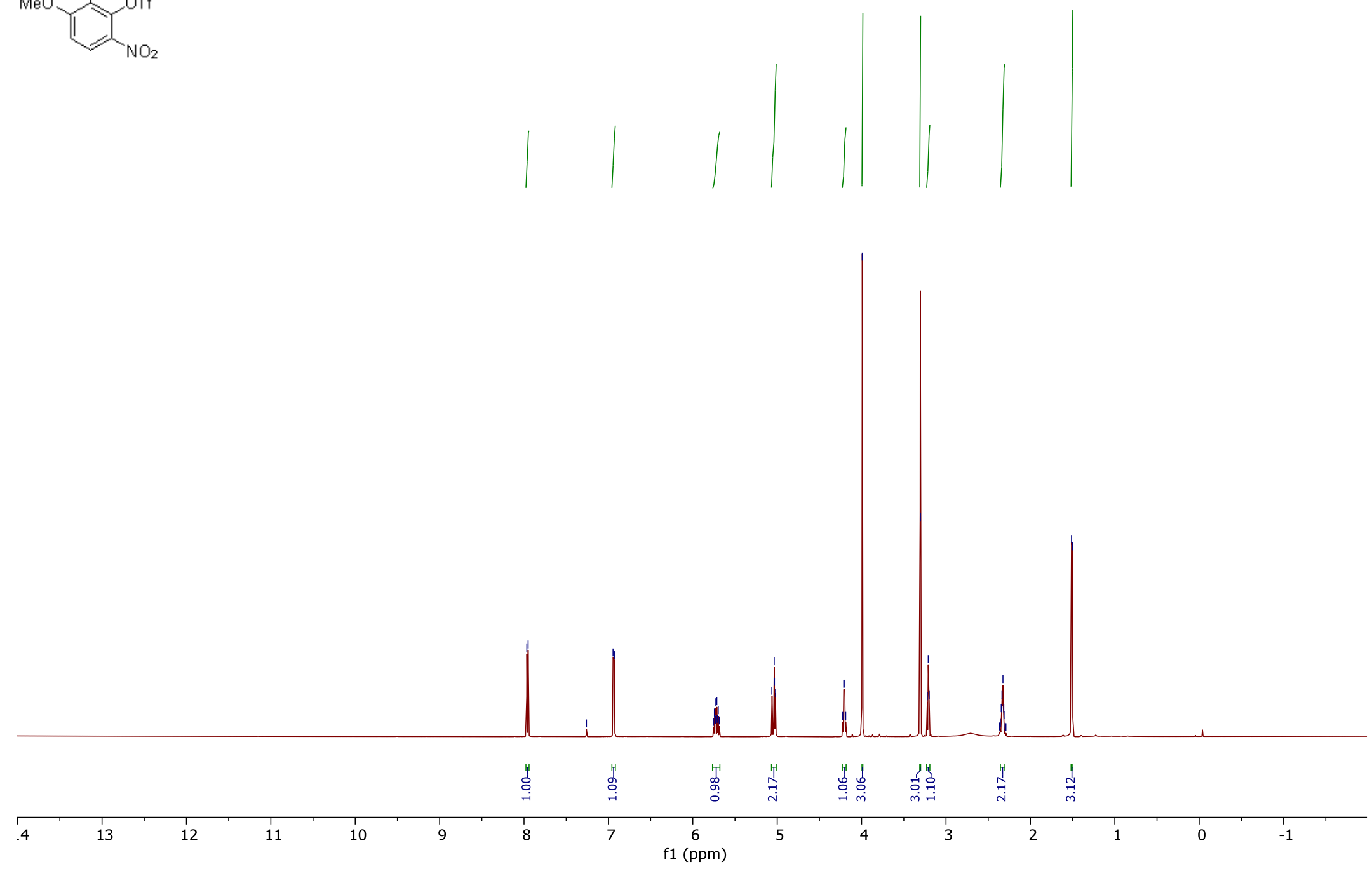

Figure 47: ${ }^{1} \mathrm{H}$ NMR of Compound 142 

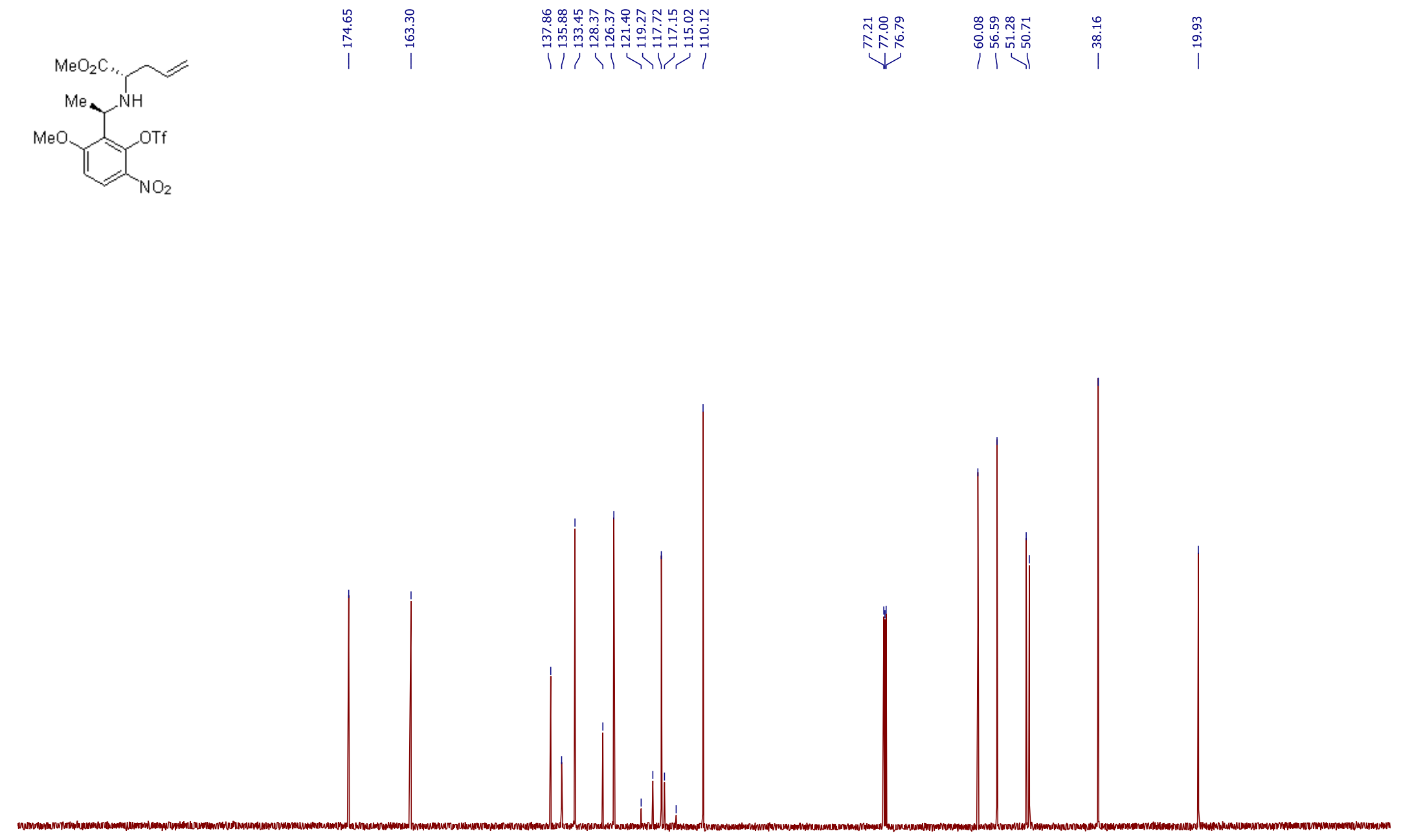
$140 \quad 130$ $120 \underset{f 1(\mathrm{ppm})}{110} 100 \quad 90$ $80 \quad 70$ $60 \quad 50$ 40 $30 \quad 20$ $\begin{array}{lll}10 & 0 & -10\end{array}$

Figure 48: ${ }^{13} \mathrm{C}$ NMR of Compound 142 

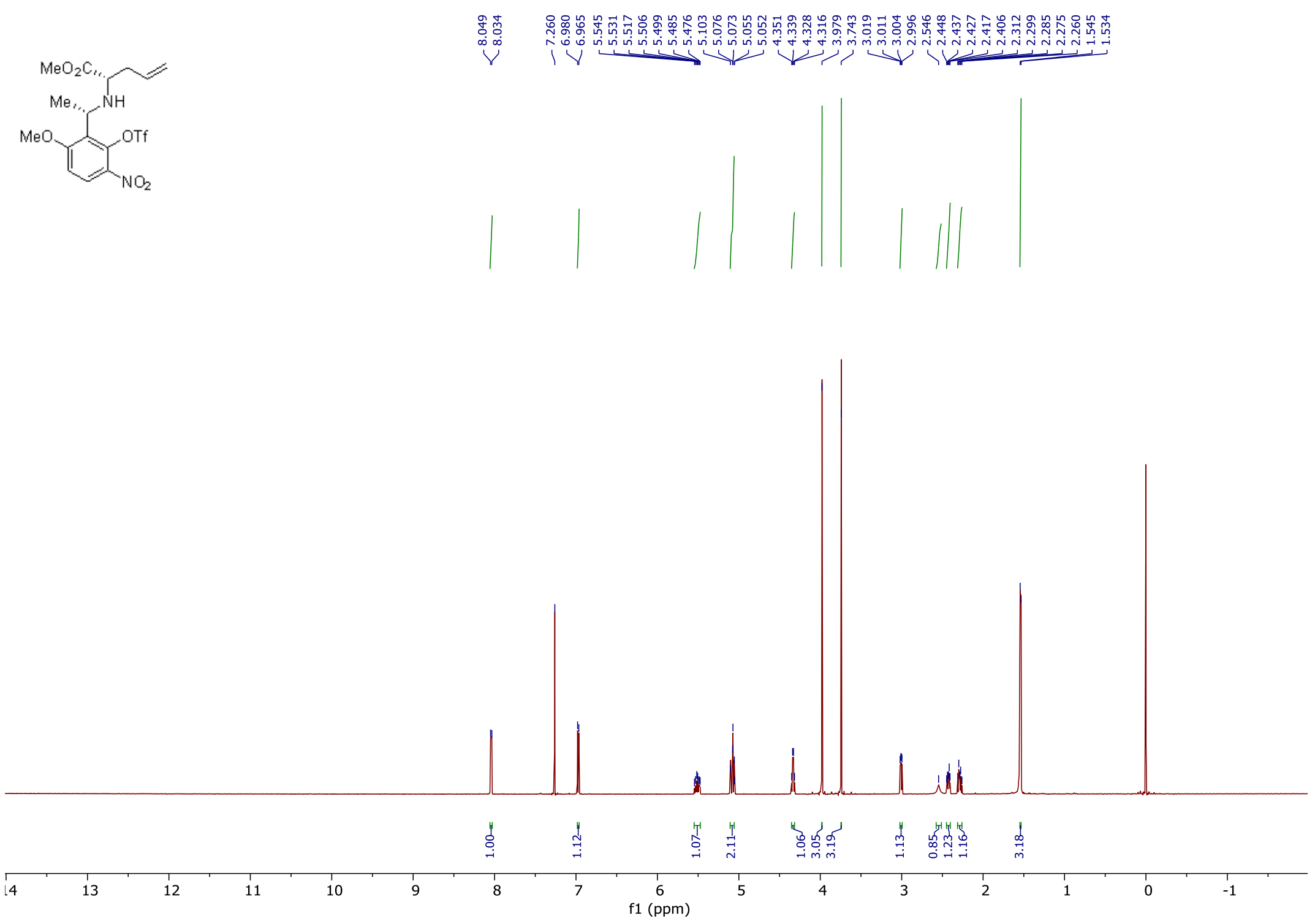

Figure 49: ${ }^{1} \mathrm{H}$ NMR of Compound 143 


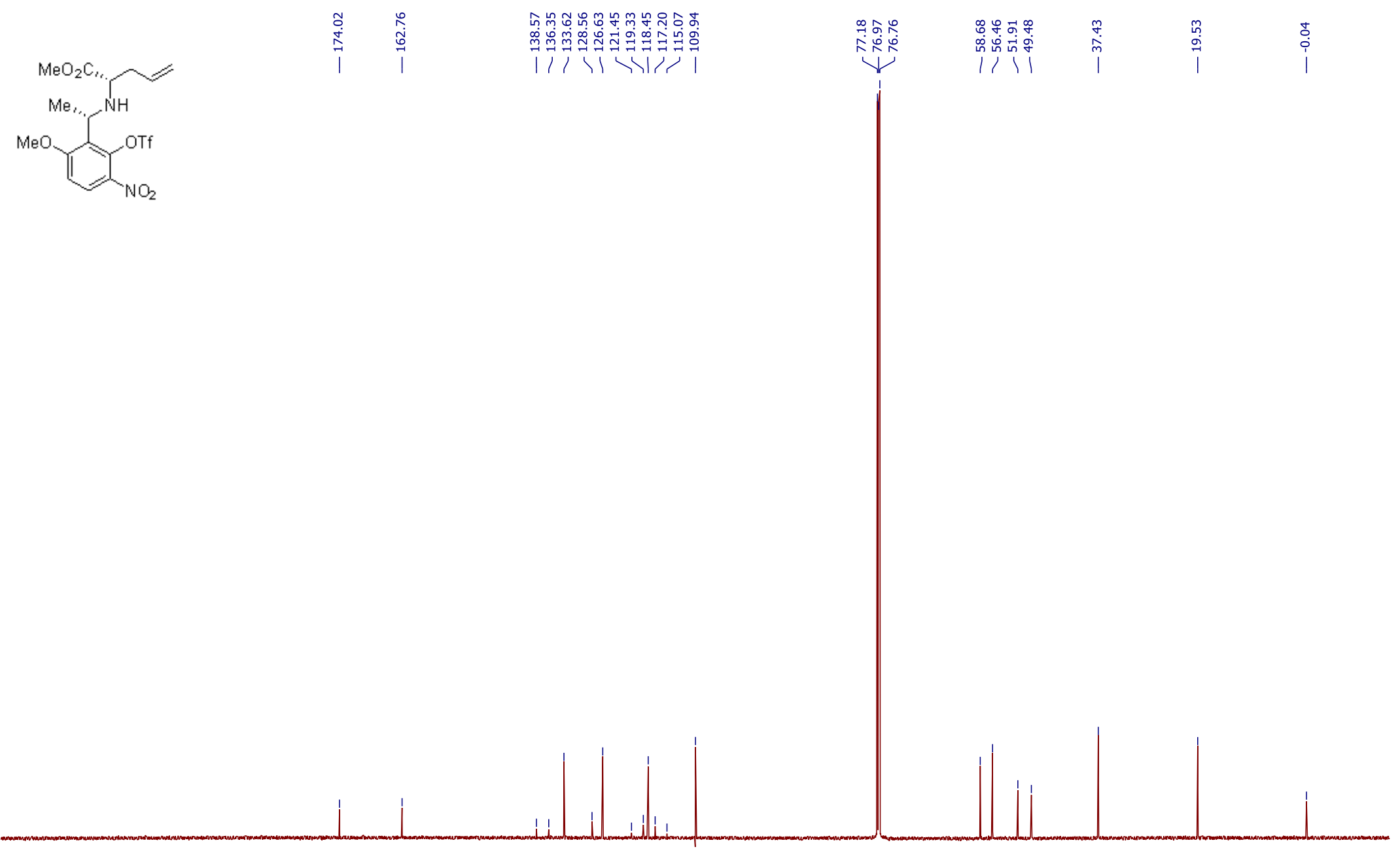

$\begin{array}{llllllllllllllllllllllllllllll}230 & 220 & 210 & 200 & 190 & 180 & 170 & 160 & 150 & 140 & 130 & 120 & 110 & 100 & 90 & 80 & 70 & 60 & 50 & 40 & 30 & 20 & 10 & 0 & -10\end{array}$

Figure 50: ${ }^{13} \mathrm{C}$ NMR of Compound 143 

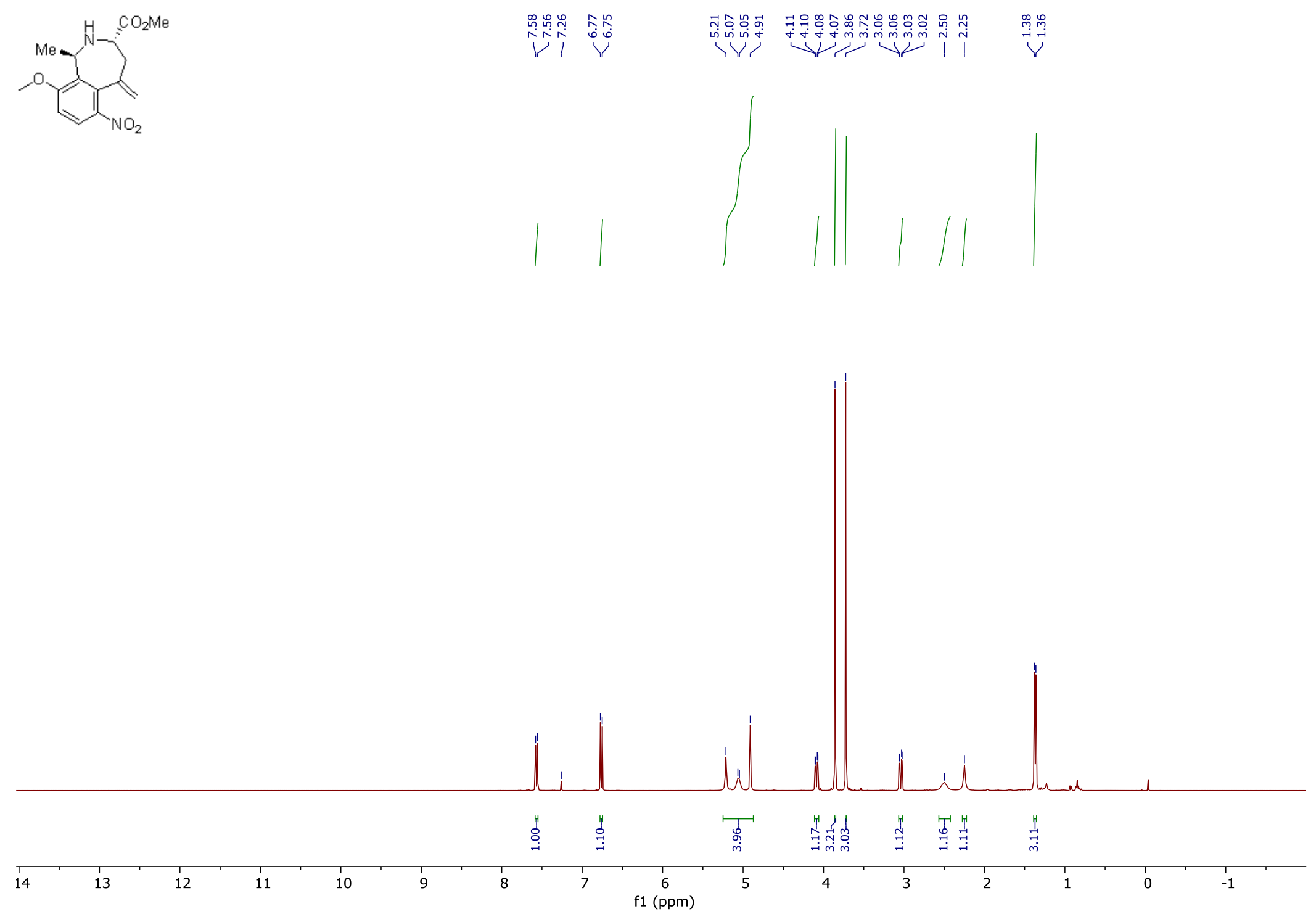

Figure 51: ${ }^{1} \mathrm{H}$ NMR of Compound 144 


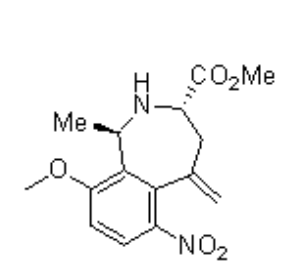

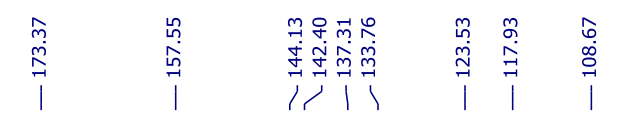

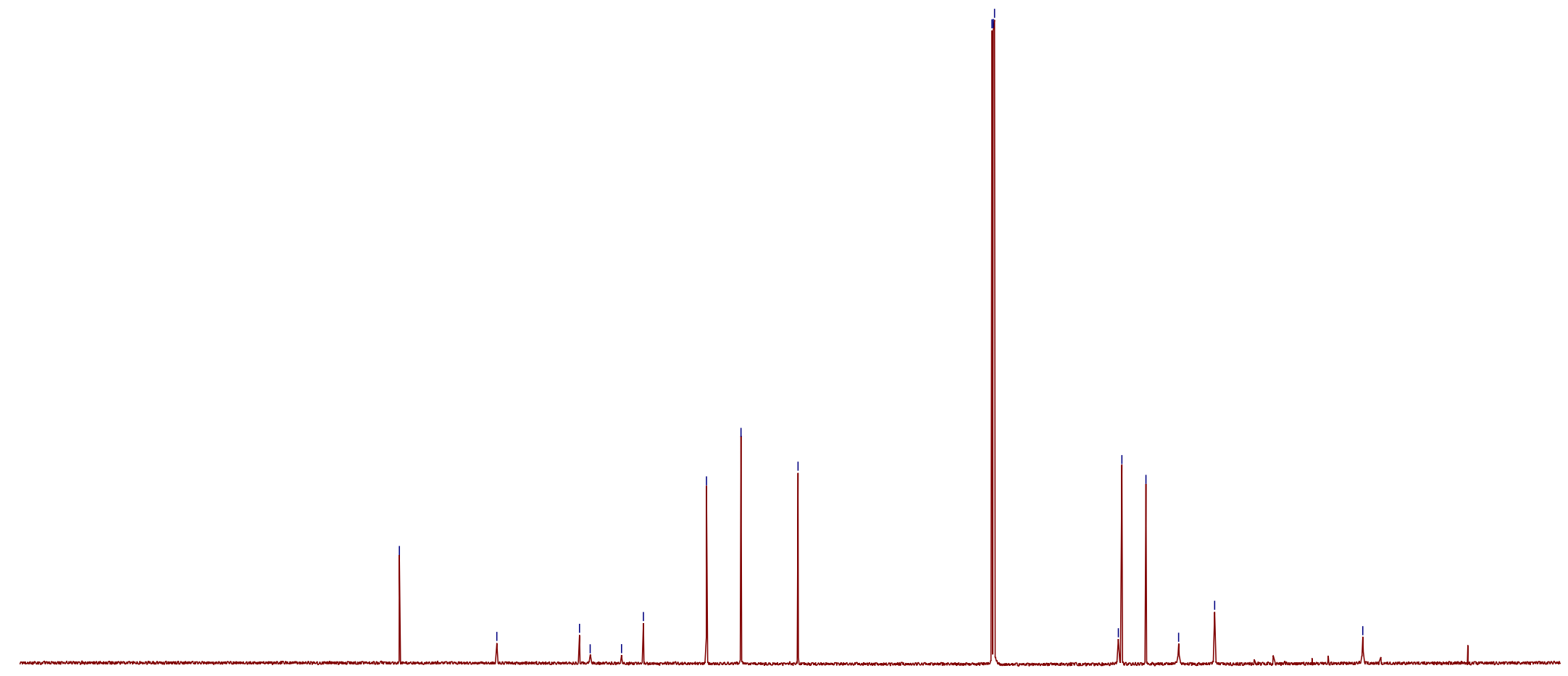

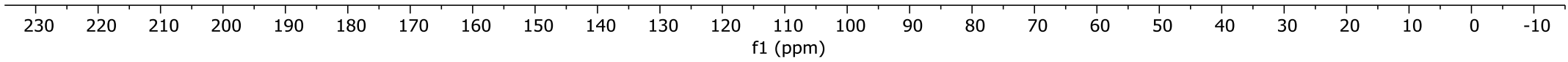

Figure 52: ${ }^{13} \mathrm{C}$ NMR of Compound 144 


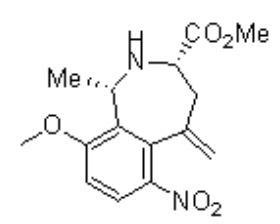

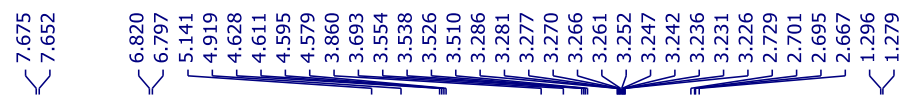

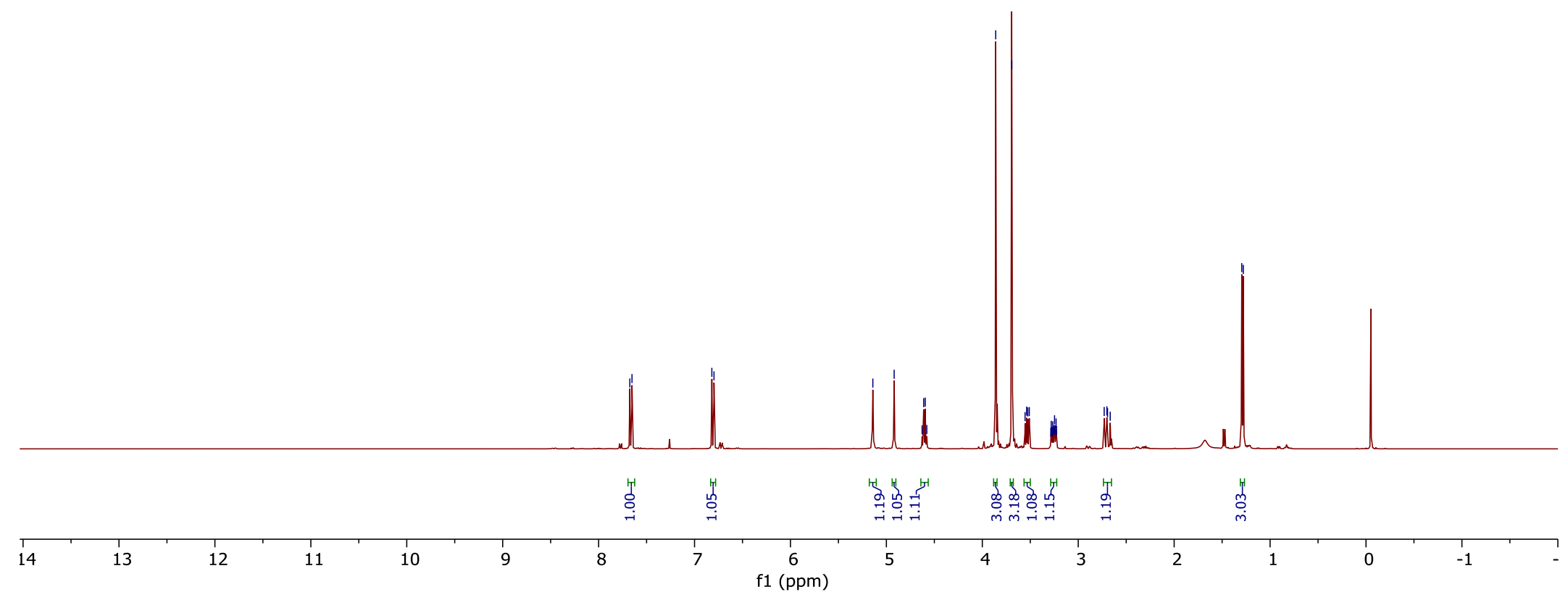

Figure 53: ${ }^{1} \mathrm{H}$ NMR of Compound 145 

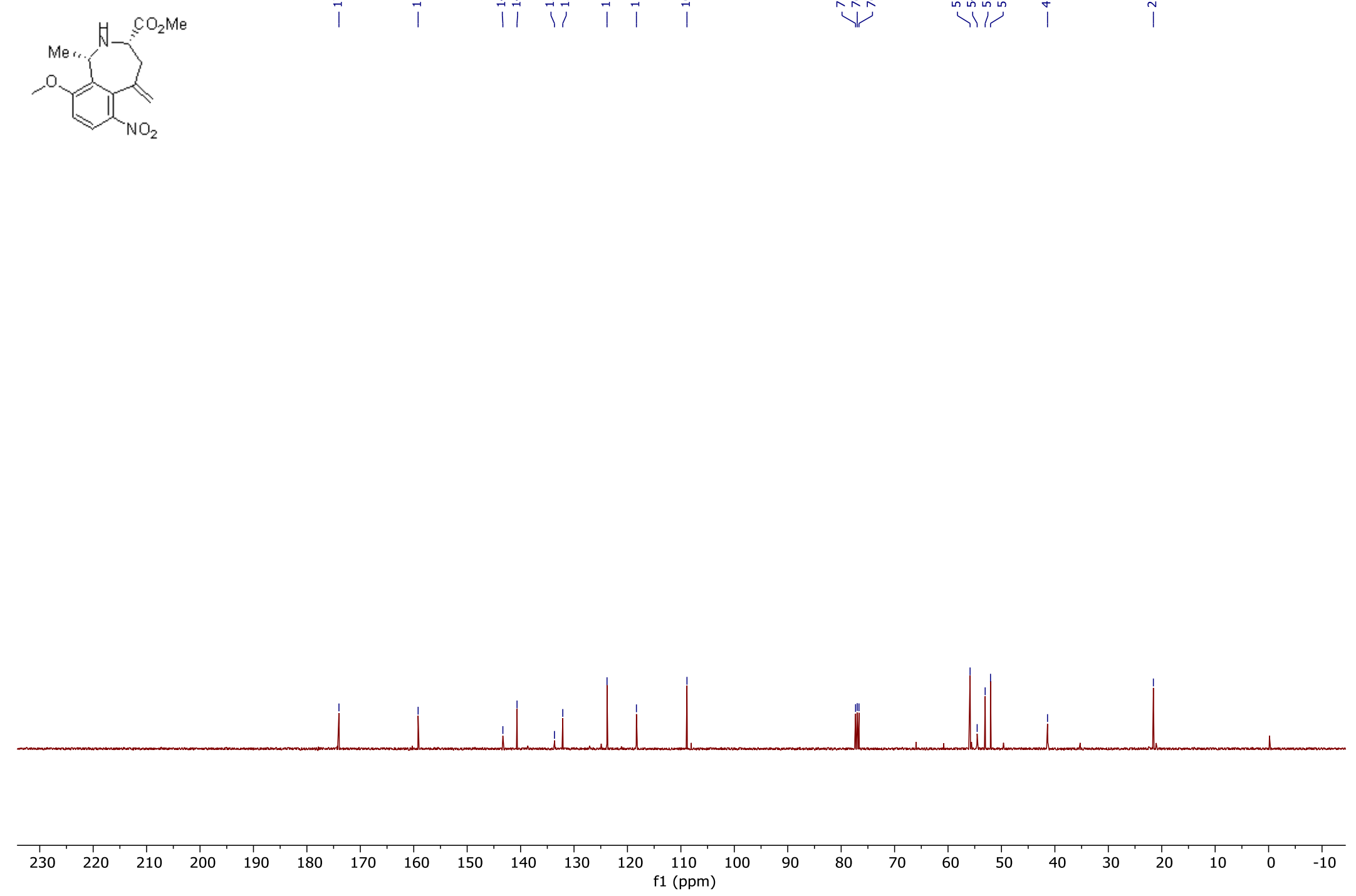

Figure 54: ${ }^{13} \mathrm{C}$ NMR of Compound $\mathbf{1 4 5}$ 


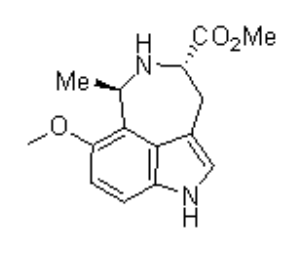

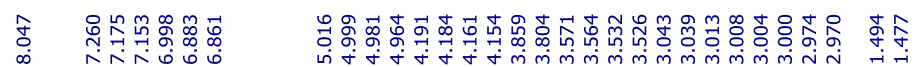

综

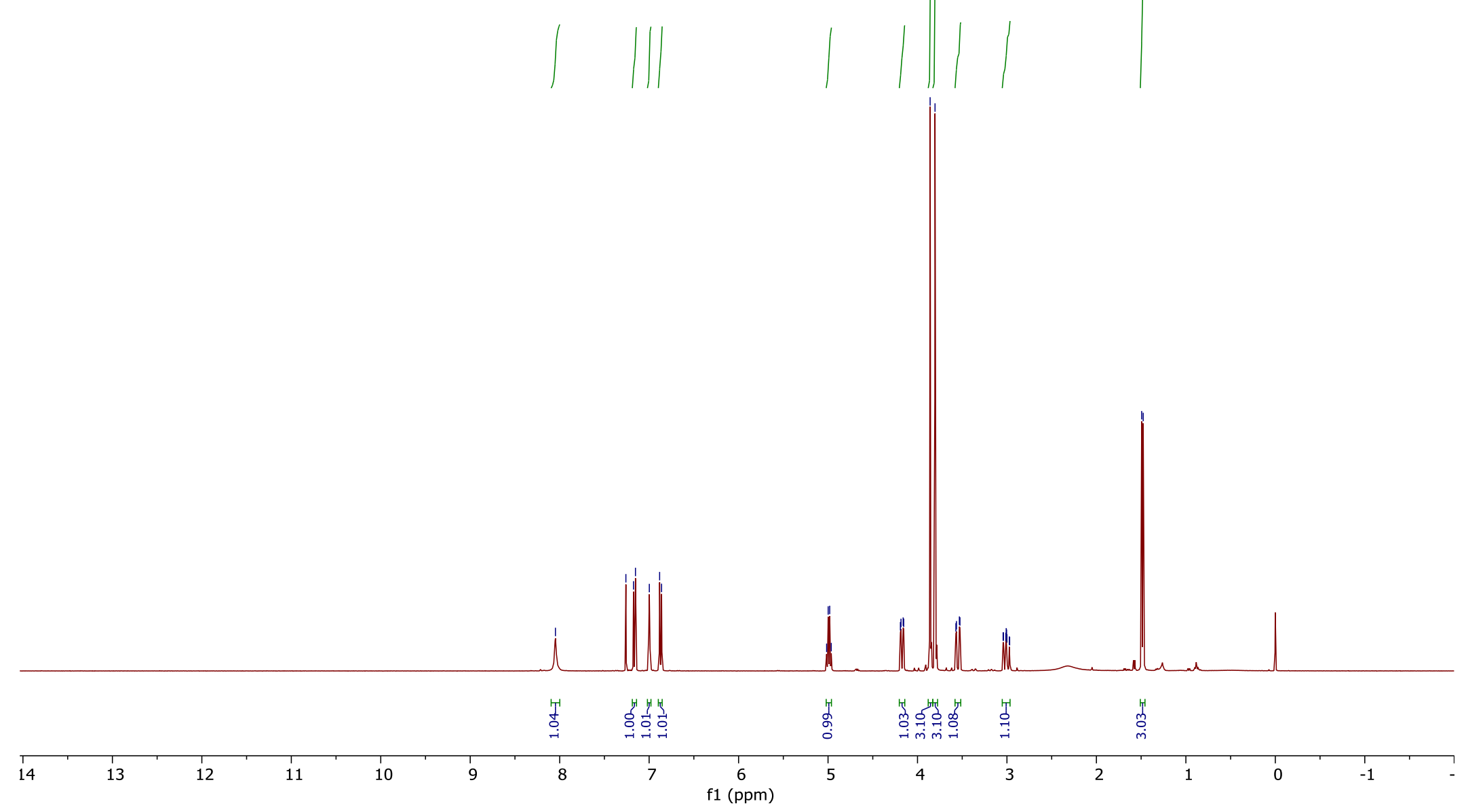

Figure 55: ${ }^{1} \mathrm{H}$ NMR of Compound 146 


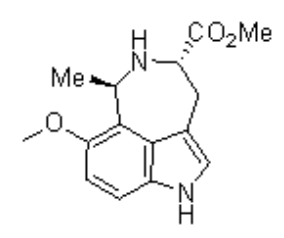

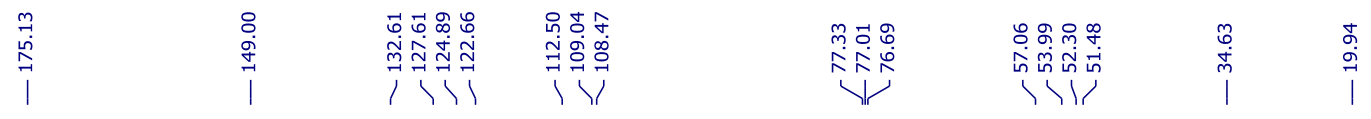

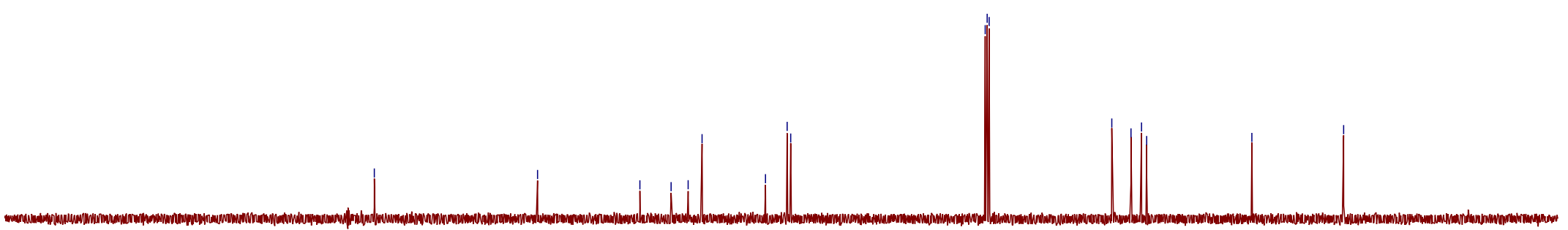

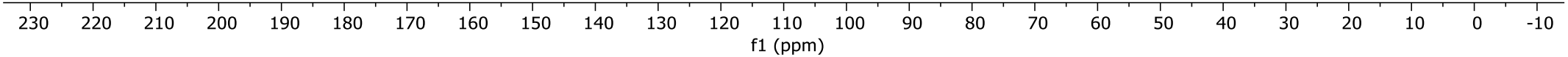

Figure 56: ${ }^{13} \mathrm{C}$ NMR of Compound 146 


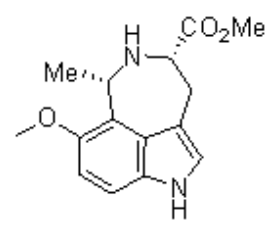

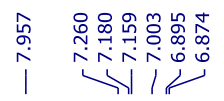

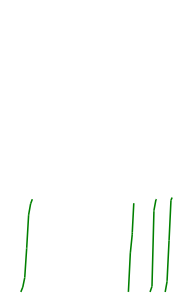

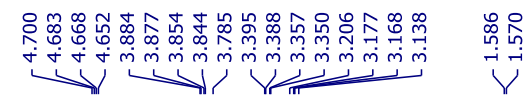
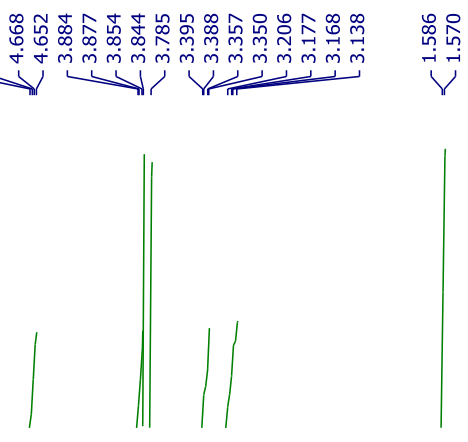

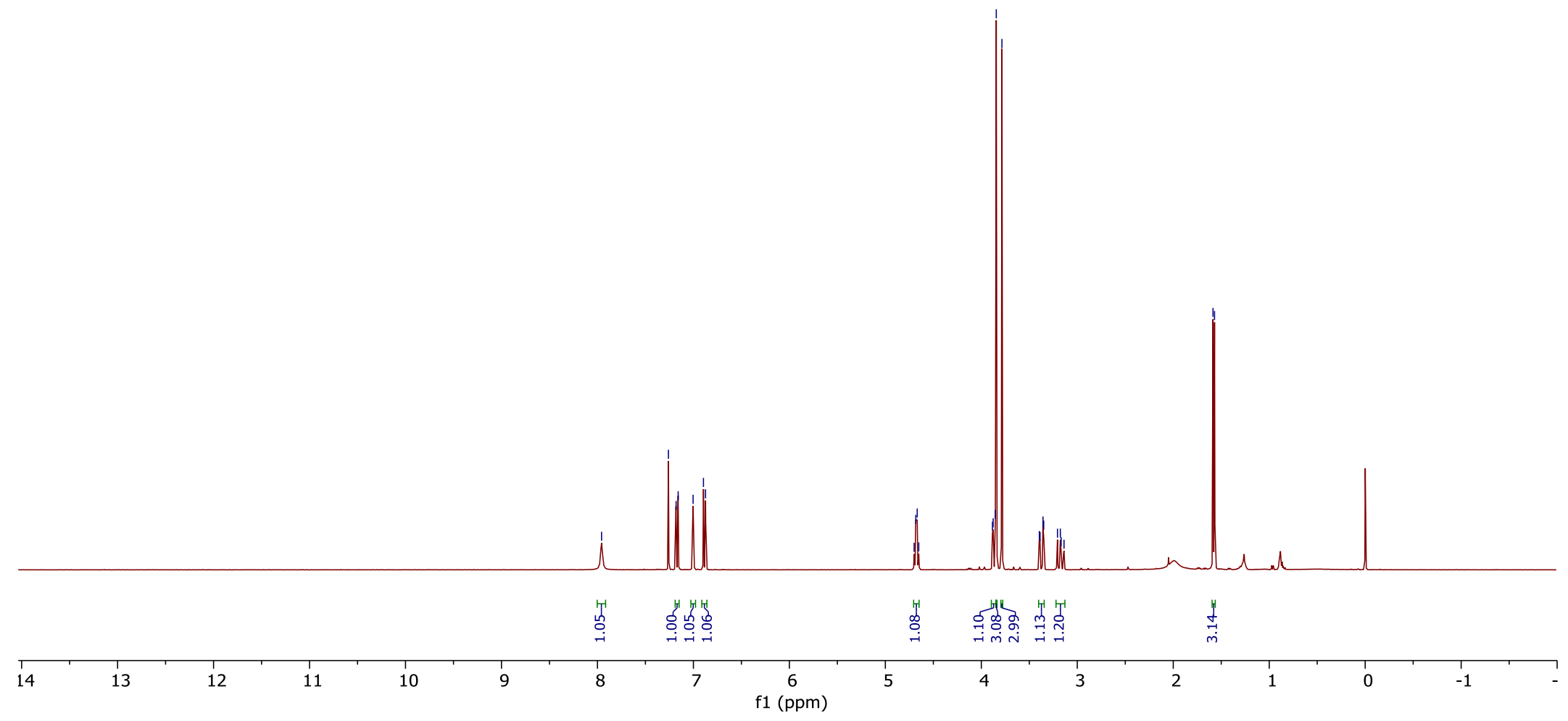

Figure 57: ${ }^{1} \mathrm{H}$ NMR of Compound 147

139 

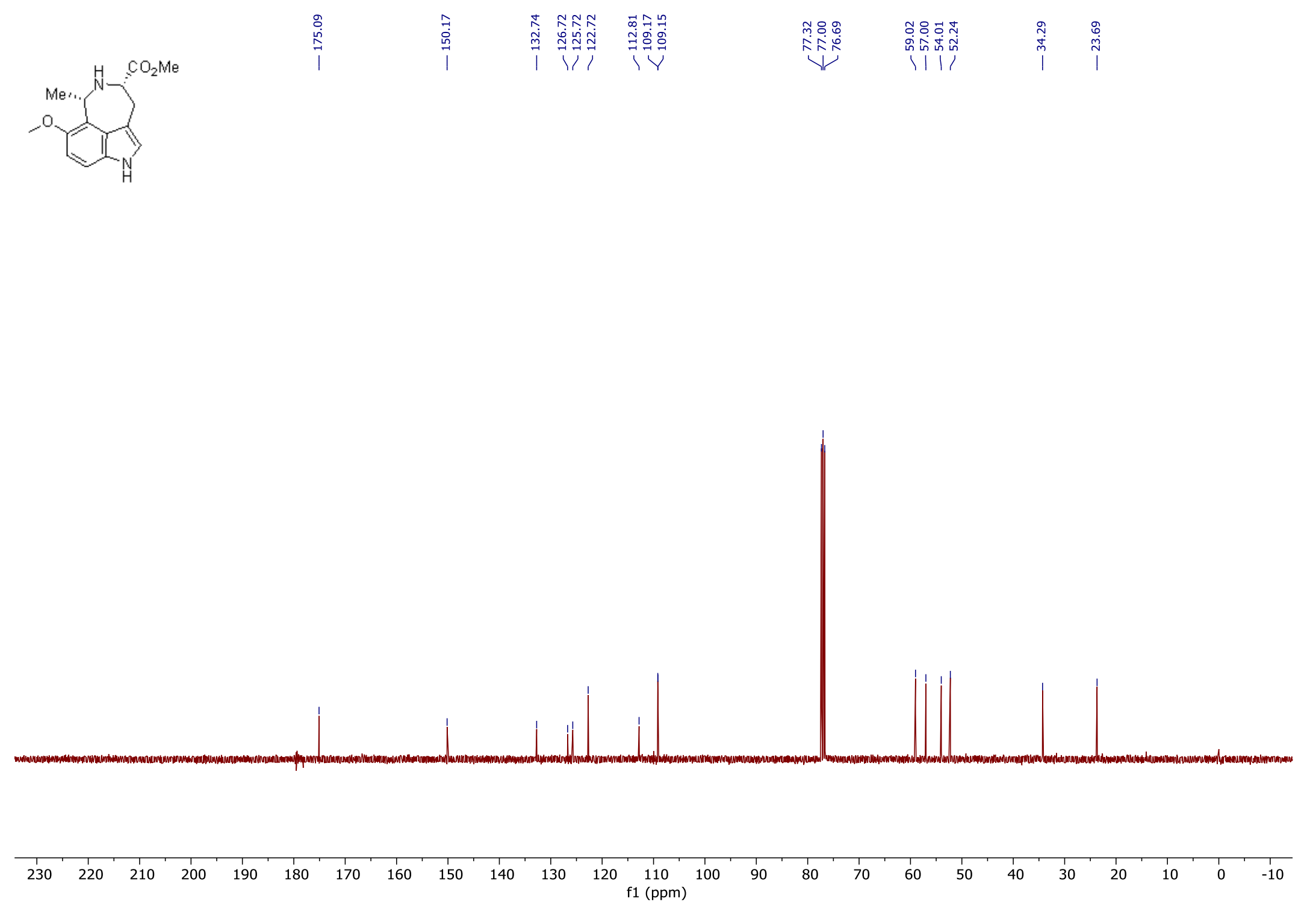

Figure 58: ${ }^{13} \mathrm{C}$ NMR of Compound 147 

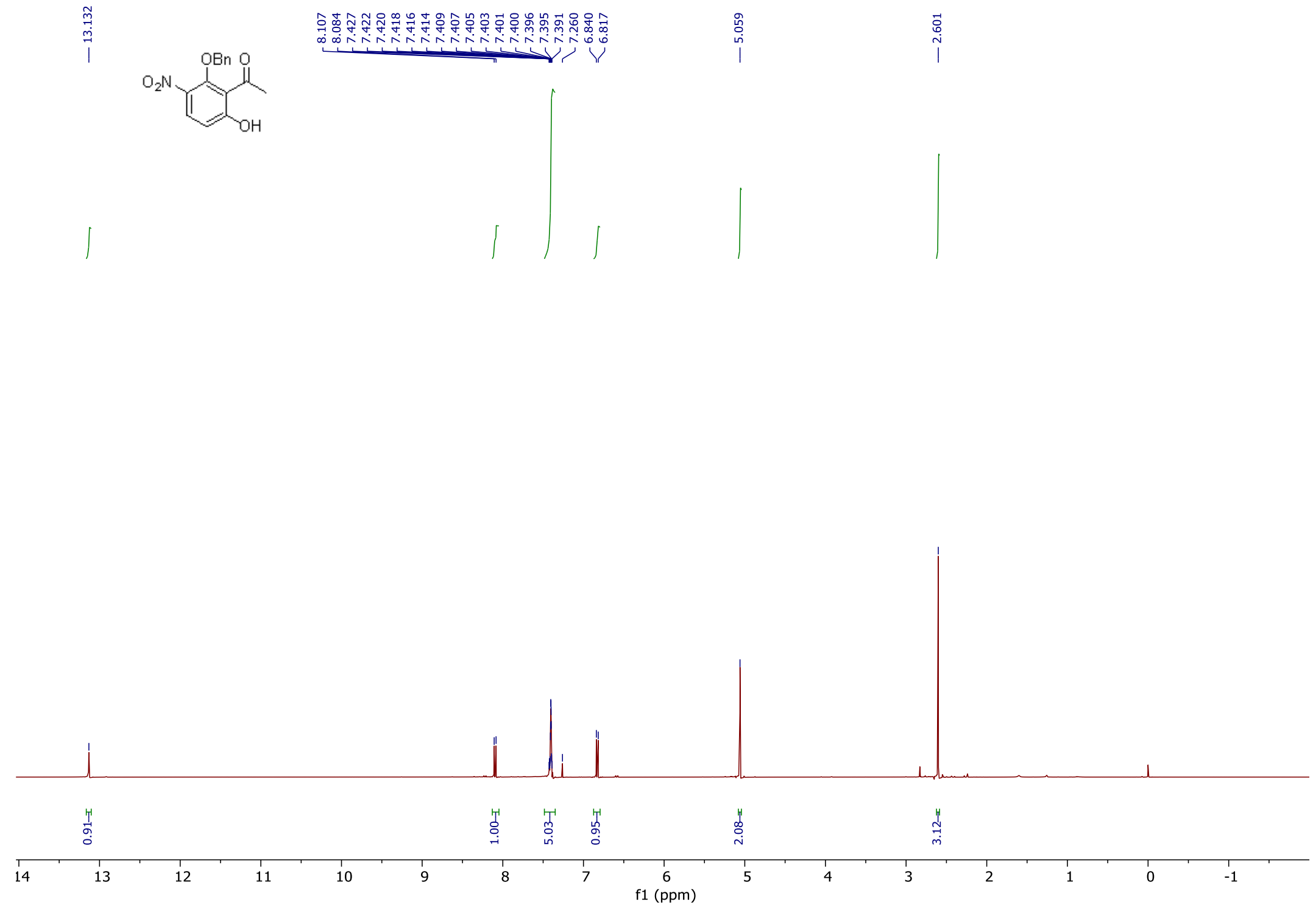

Figure 59: ${ }^{1} \mathrm{H}$ NMR of Compound 149 

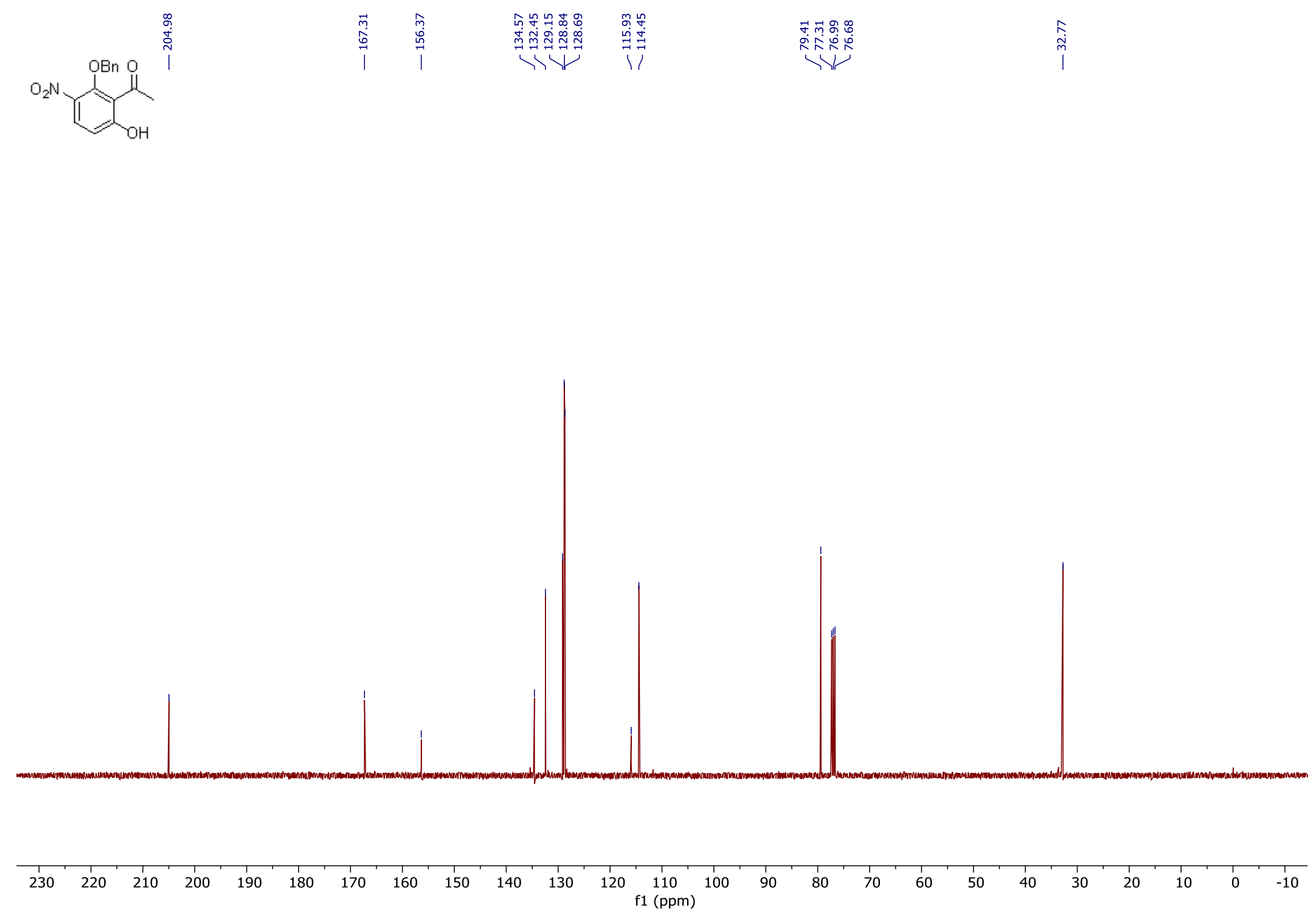

Figure 60: ${ }^{13} \mathrm{C}$ NMR of Compound 149 


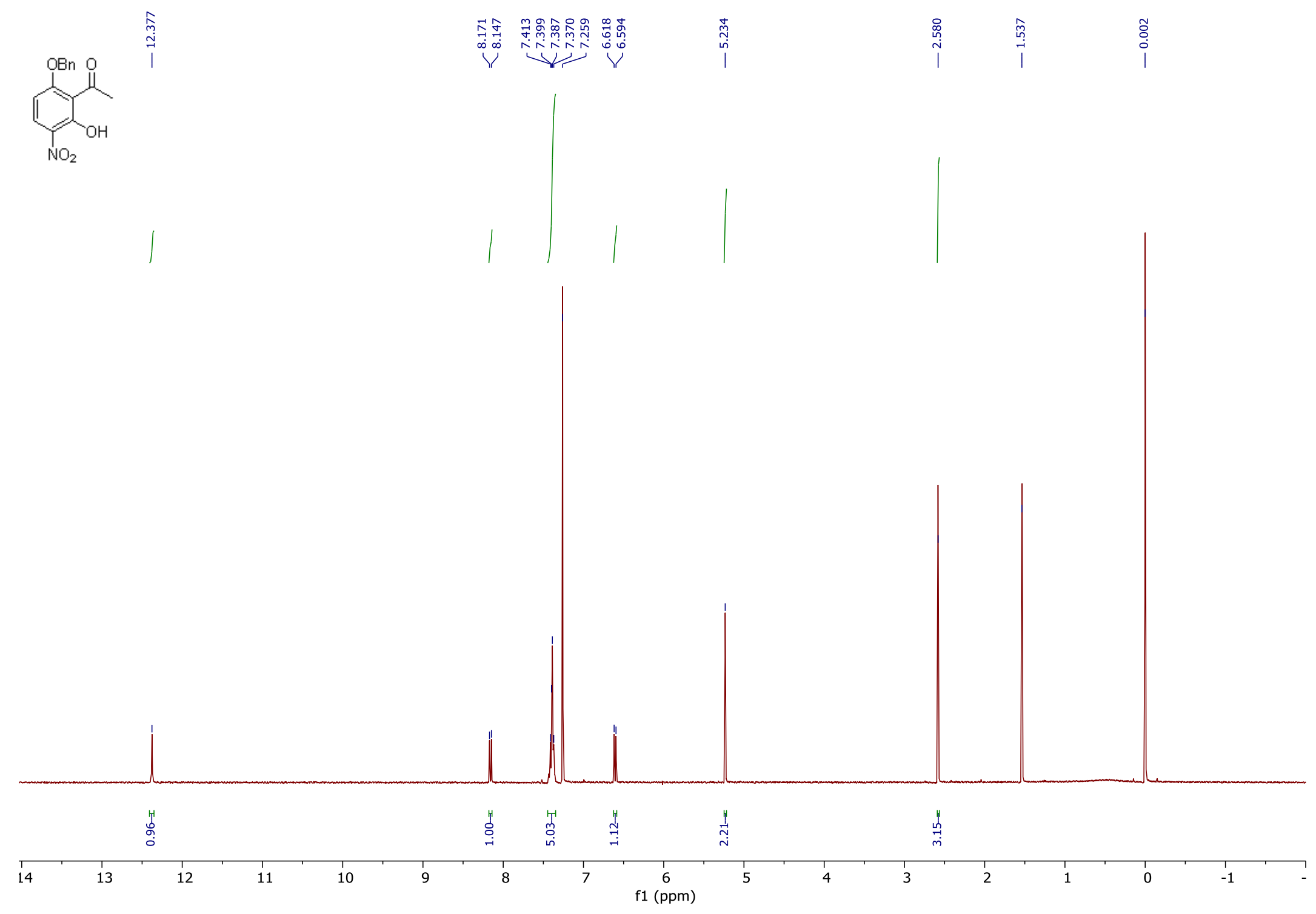

Figure 61: ${ }^{1} \mathrm{H}$ NMR of Compound 150 

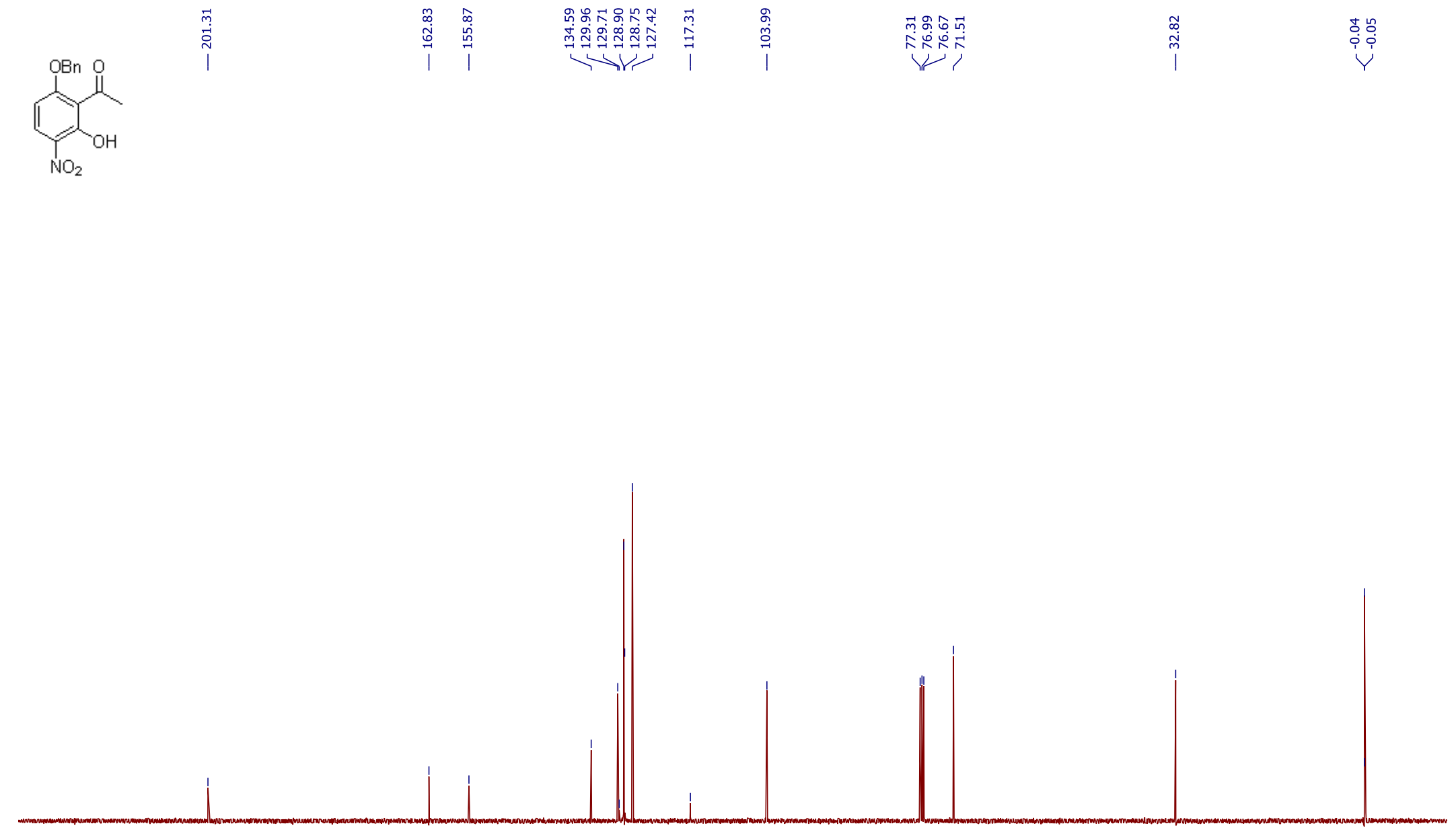

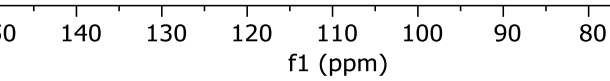

$70 \quad 60$

$50 \quad 40$

$30 \quad 20 \quad 10 \quad 0 \quad-10$

Figure 62: ${ }^{13} \mathrm{C}$ NMR of Compound 150 


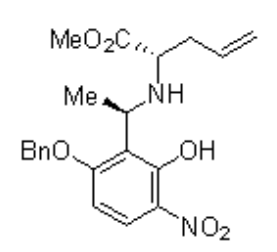

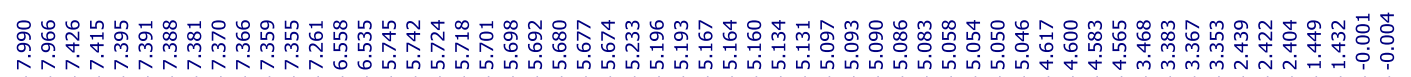
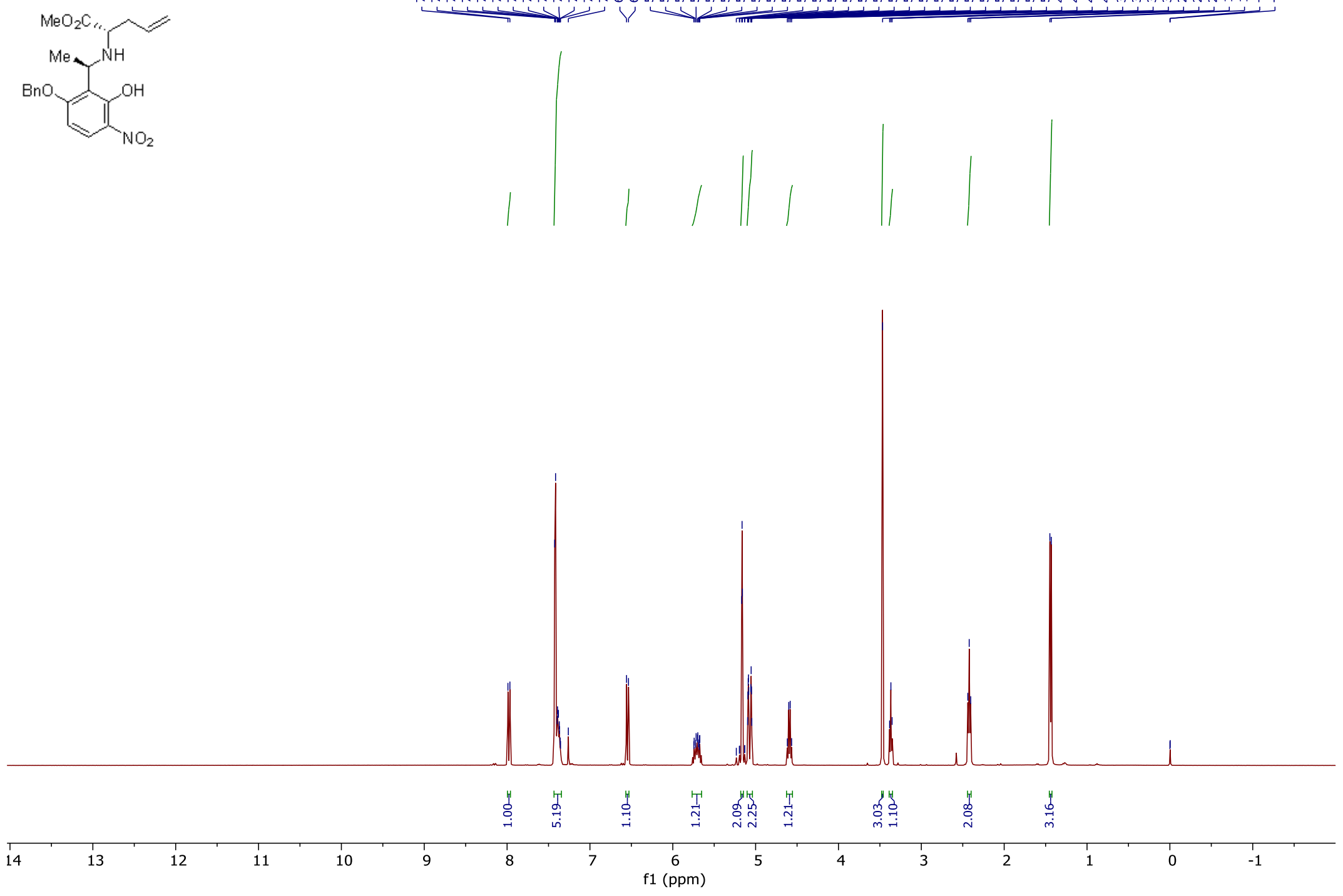

Figure 63: ${ }^{1} \mathrm{H}$ NMR of Compound 152 

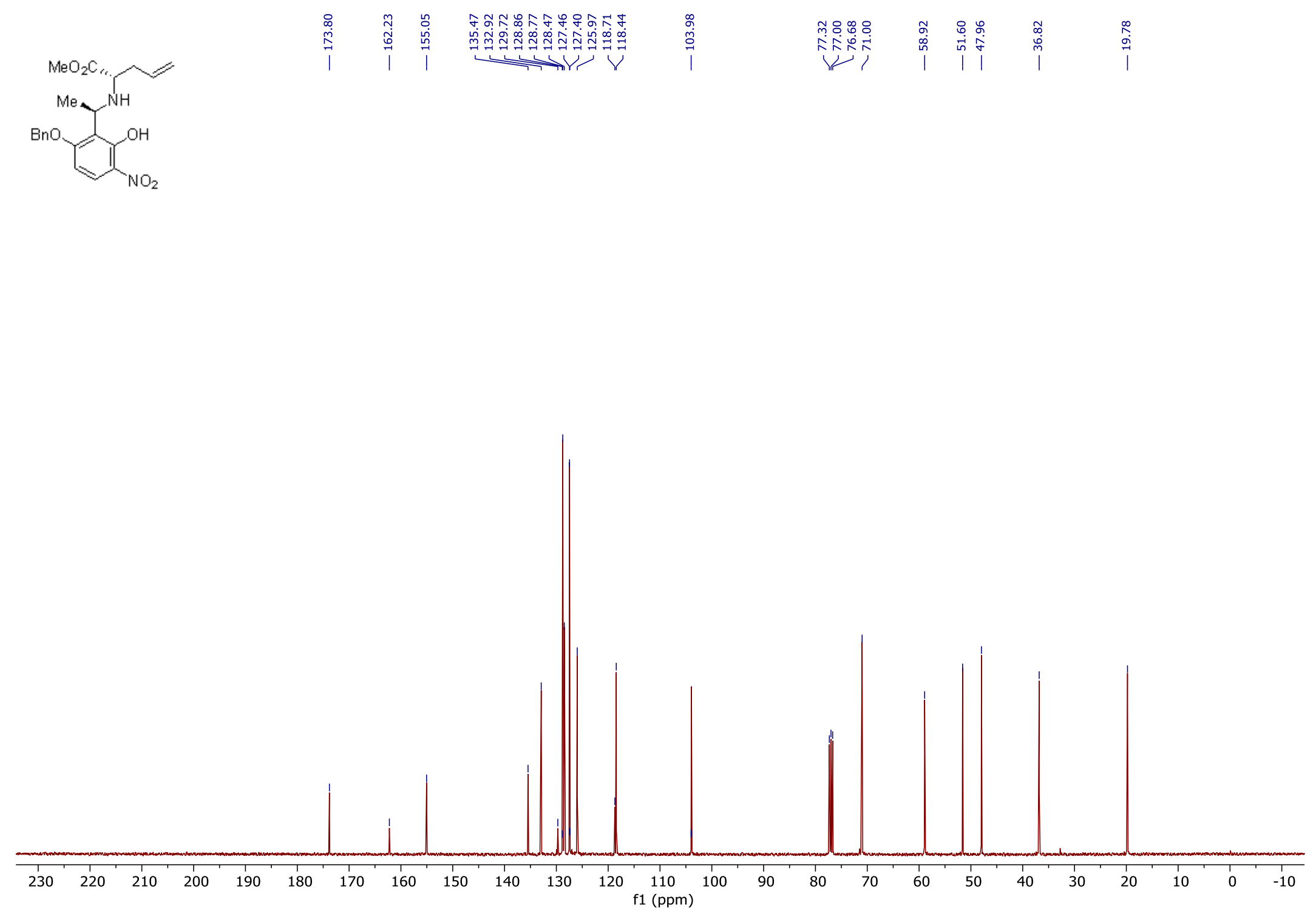

Figure 64: ${ }^{13} \mathrm{C}$ NMR of Compound 152 


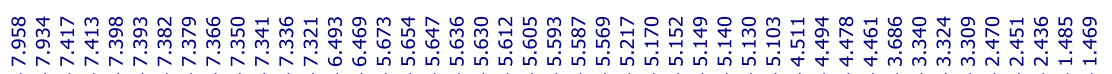
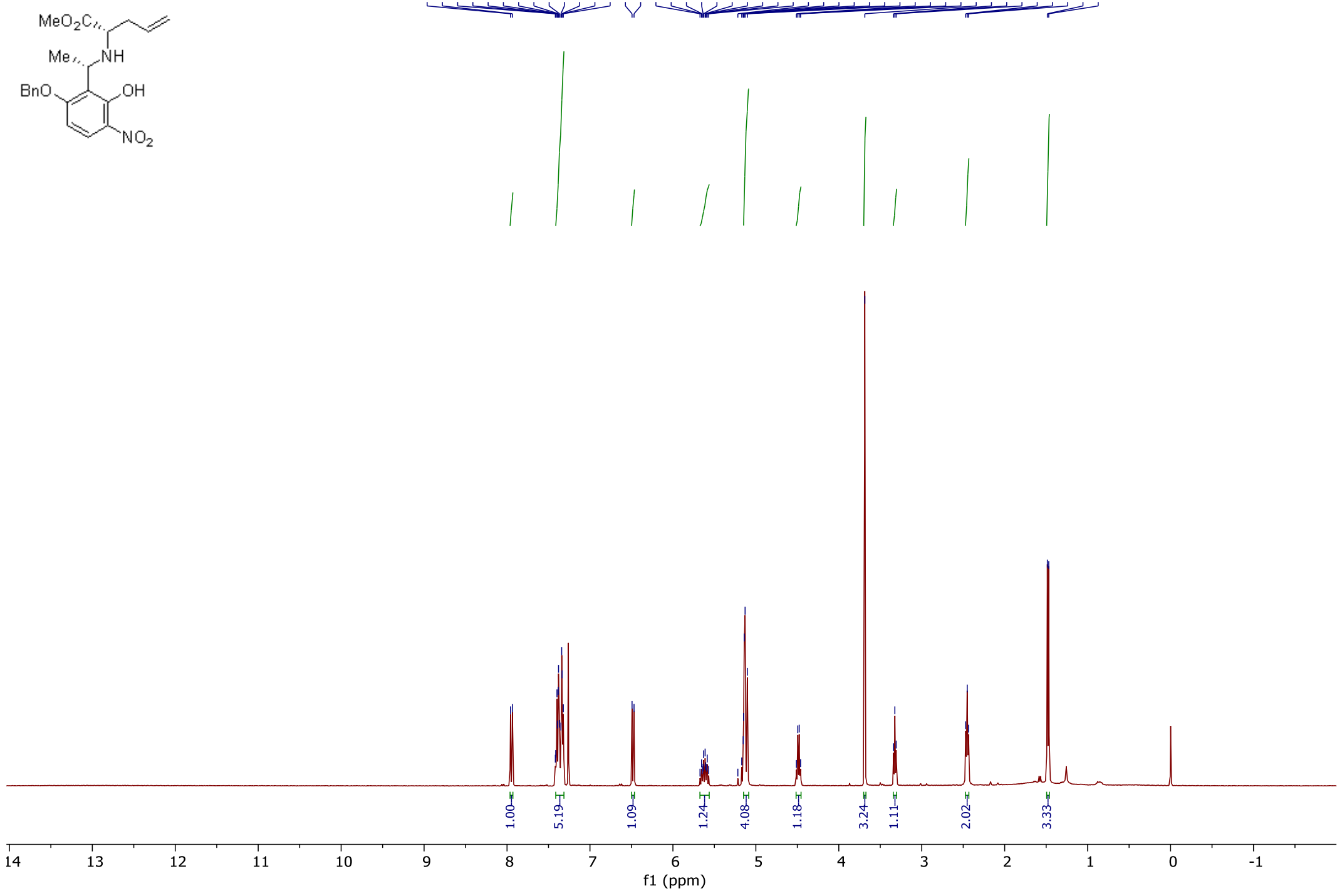

Figure 65: ${ }^{1} \mathrm{H}$ NMR of Compound $\mathbf{1 5 3}$ 

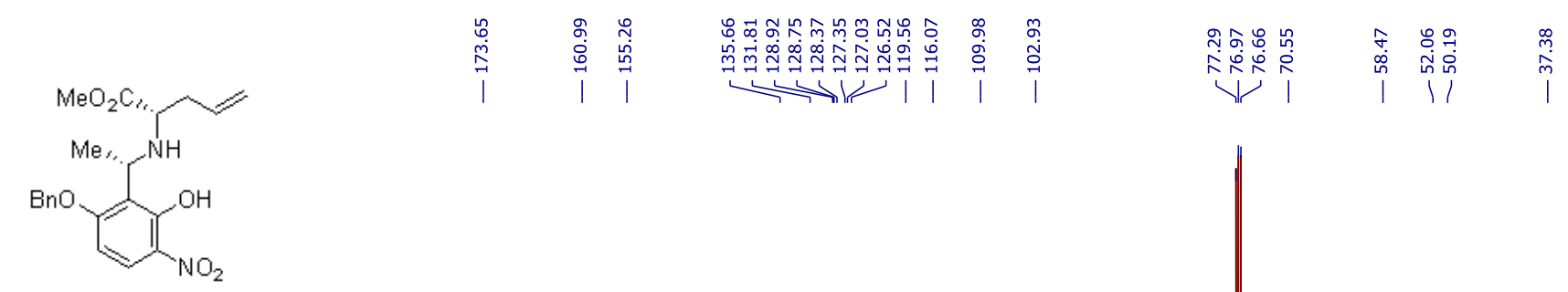

오ํ

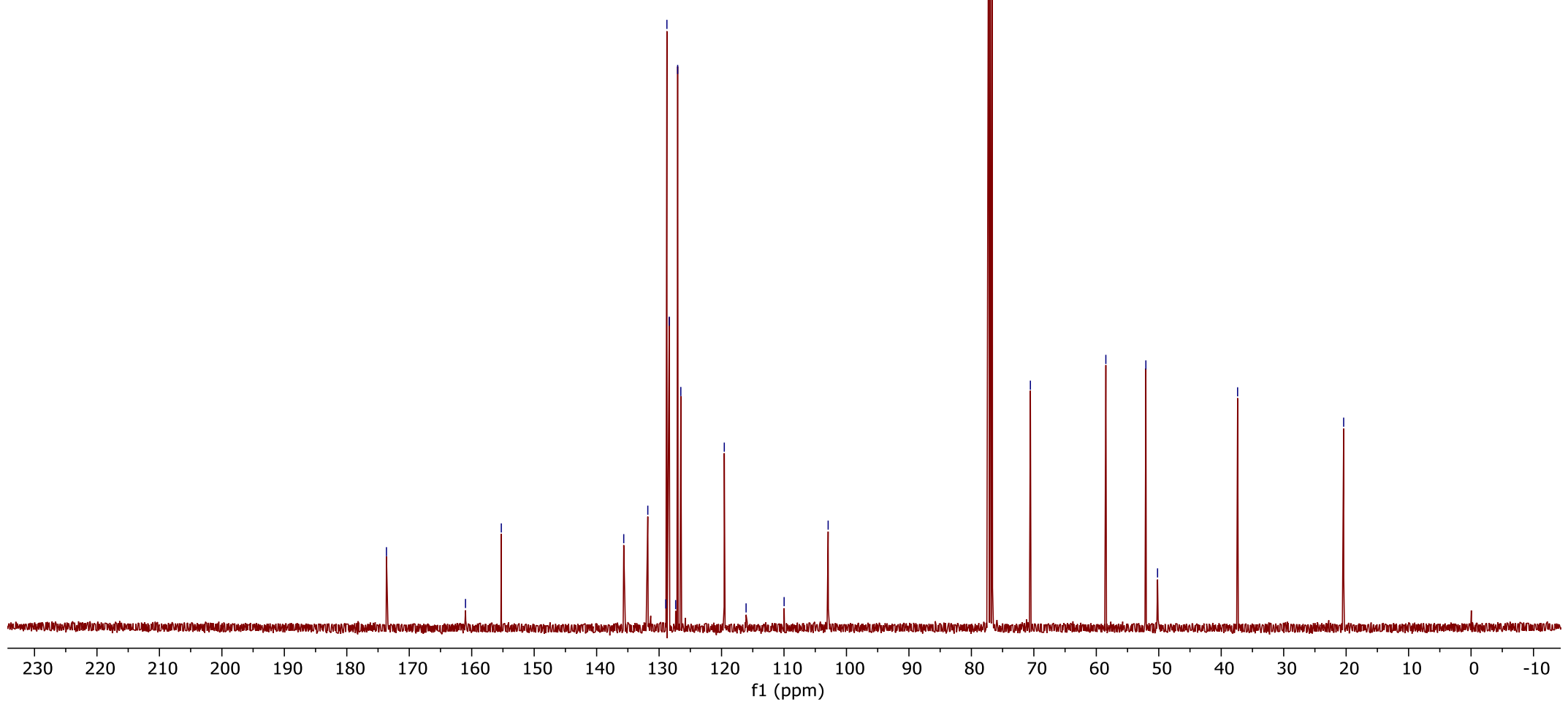

Figure 66: ${ }^{13} \mathrm{C}$ NMR of Compound 153

148 


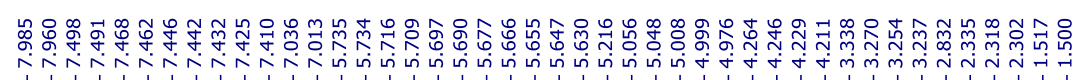
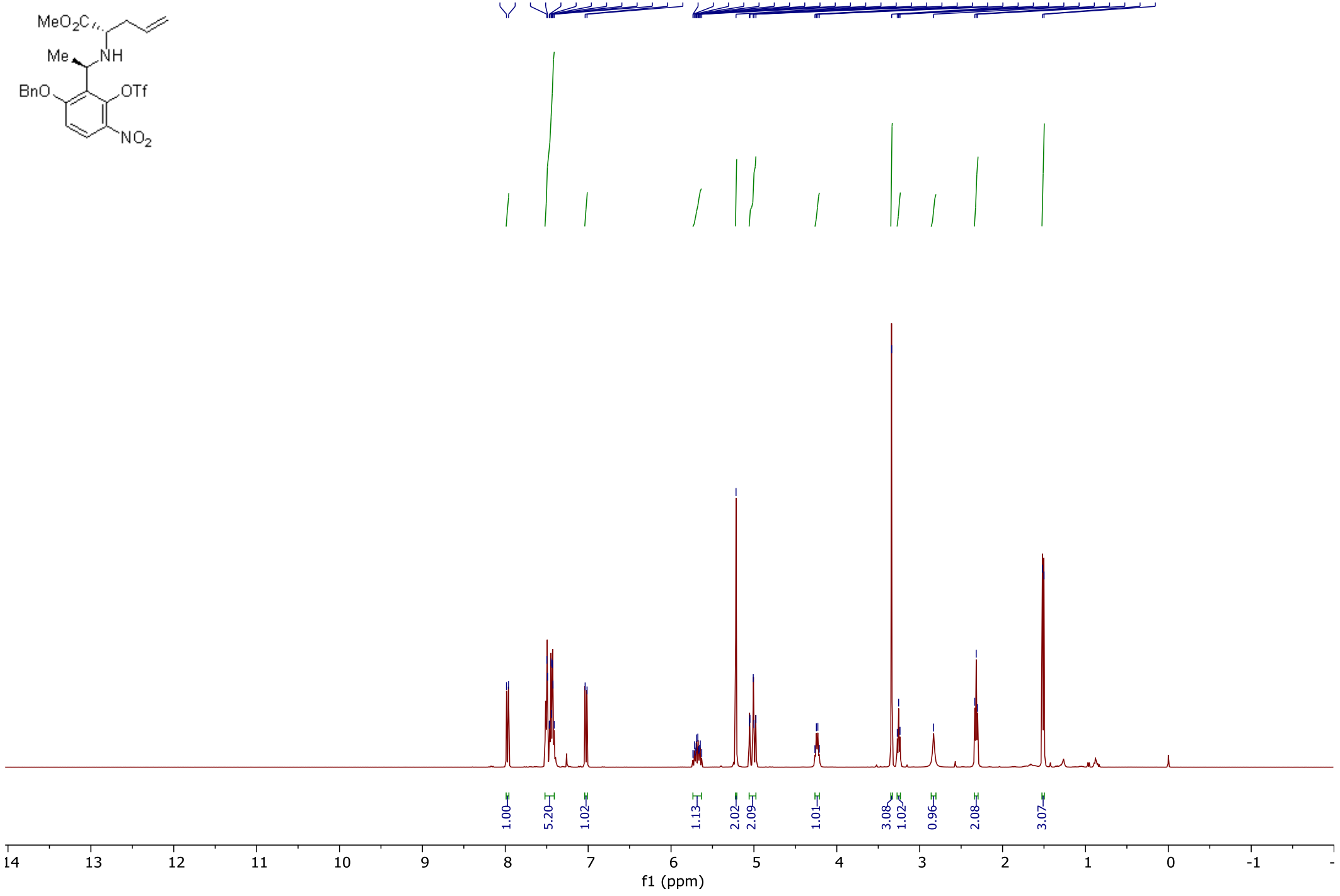

Figure 67: ${ }^{1} \mathrm{H}$ NMR of Compound 154 

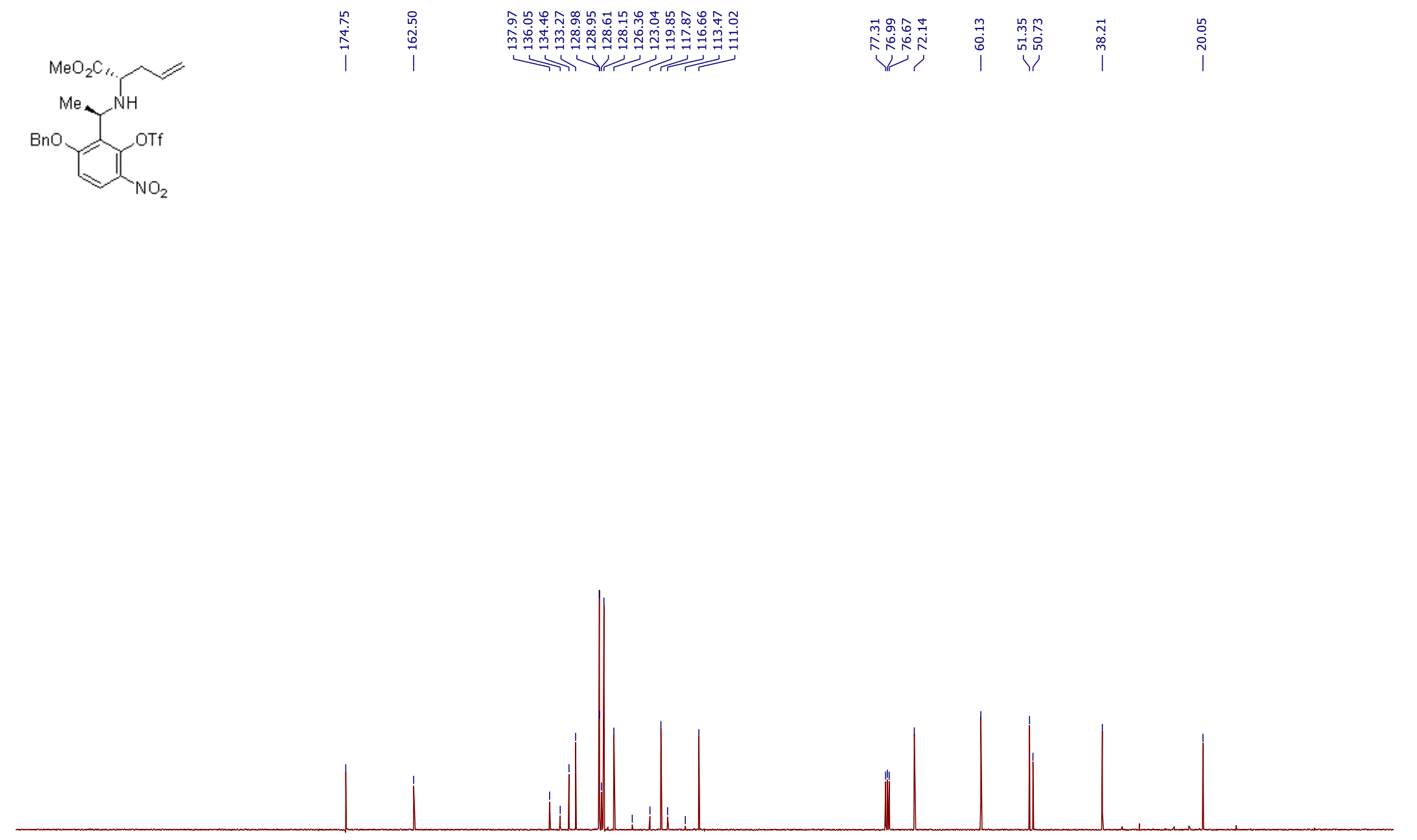

\begin{tabular}{lllllllllllllllllllllllll}
\hline 230 & 220 & 210 & 200 & 190 & 180 & 170 & 160 & 150 & 140 & 130 & 120 & 110 & 100 & 90 & 80 & 70 & 60 & 50 & 40 & 30 & 20 & 10 & 0 & -10
\end{tabular}

Figure 68: ${ }^{13} \mathrm{C}$ NMR of Compound 154 

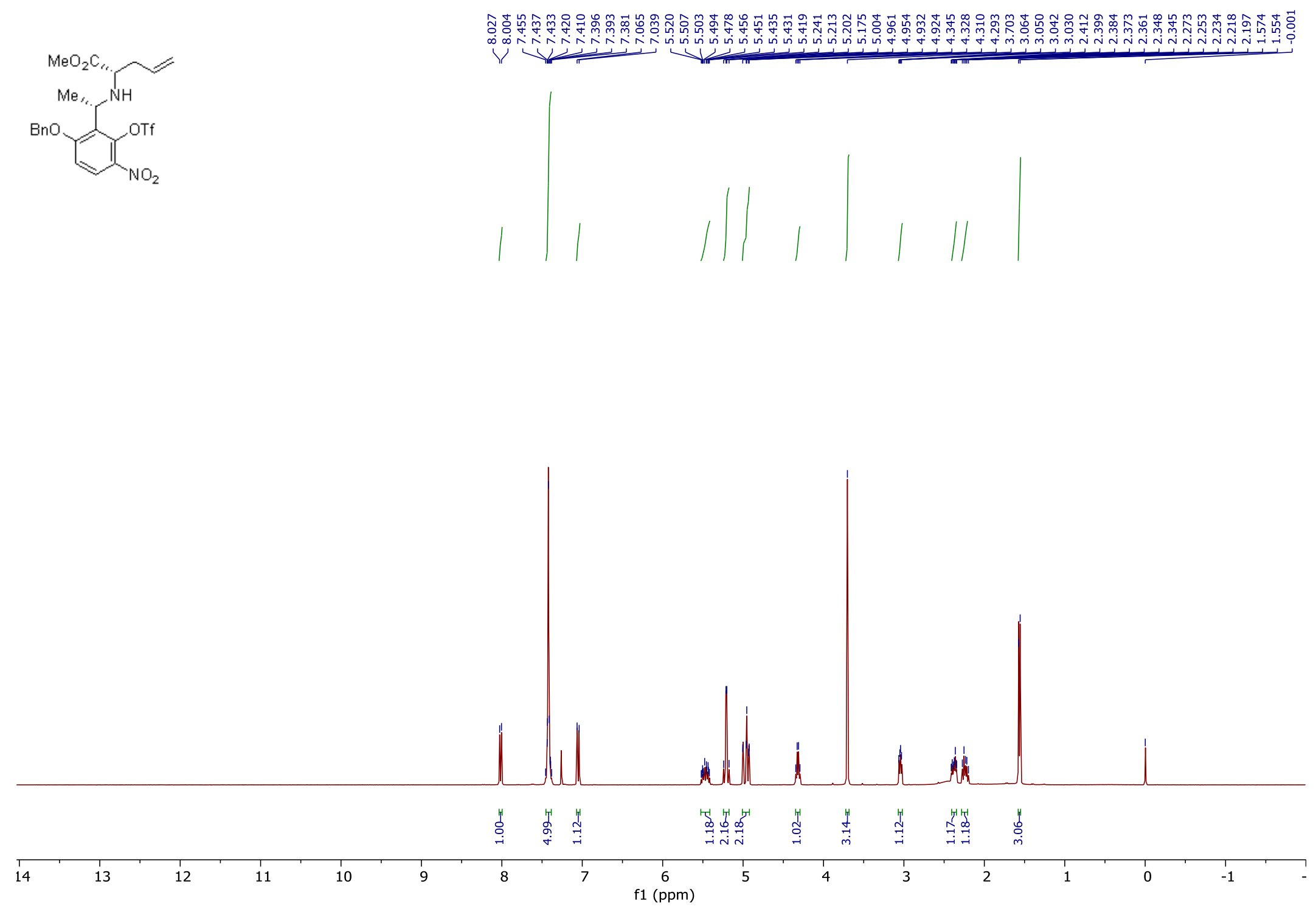

Figure 69: ${ }^{1} \mathrm{H}$ NMR of Compound 155 


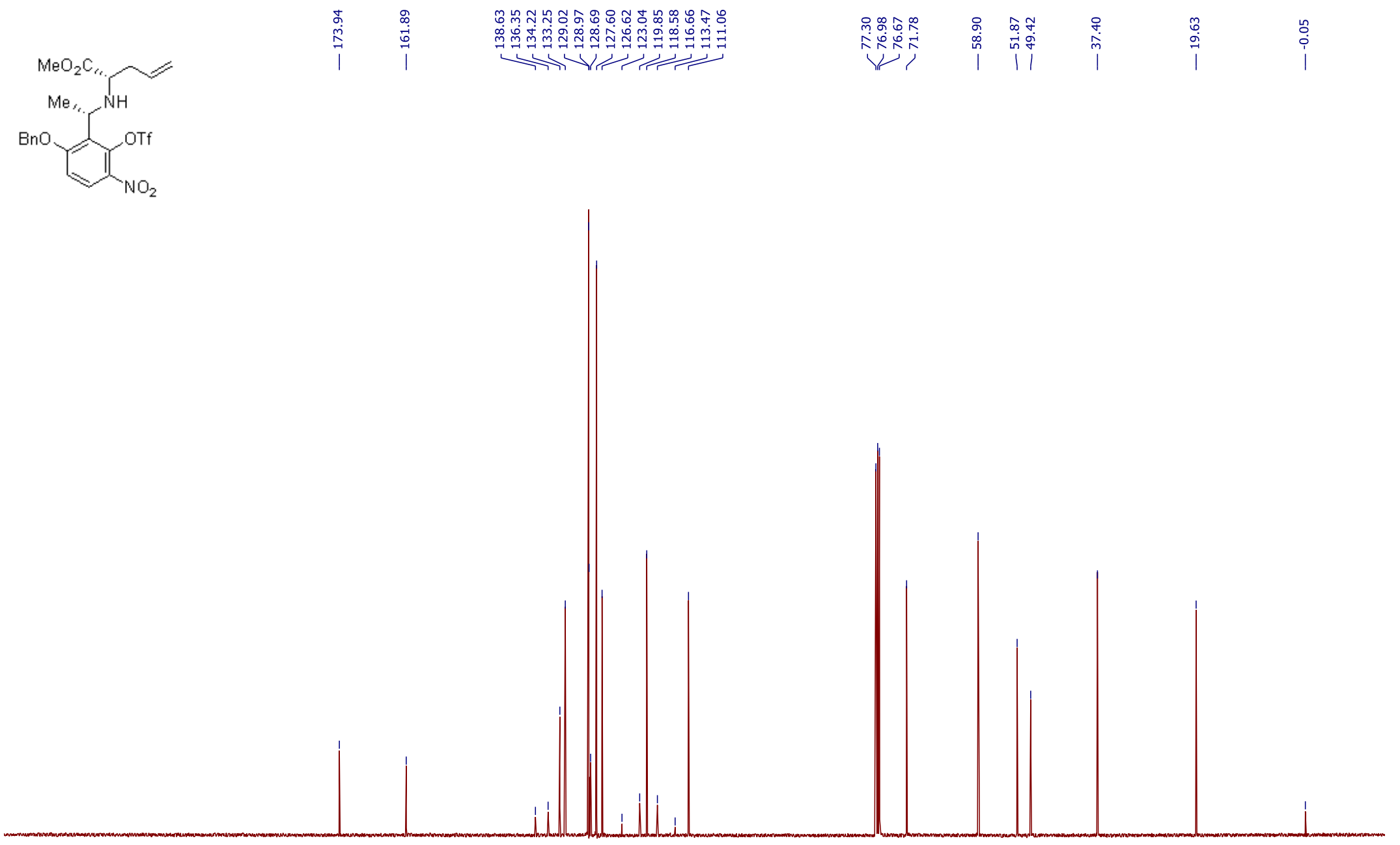

$\begin{array}{lllllllllll}230 & 220 & 210 & 200 & 190 & 180 & 170 & 160 & 150 & 140 & 130\end{array}$

$20 \quad 110 \quad 100$

90

$70 \quad 60$

$50 \quad 40$

Figure 70: ${ }^{13} \mathrm{C}$ NMR of Compound 155 


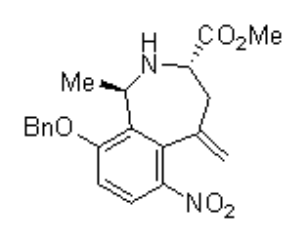

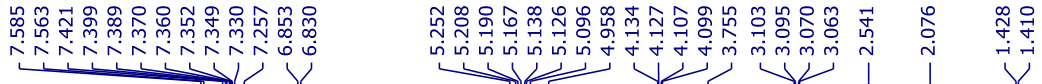
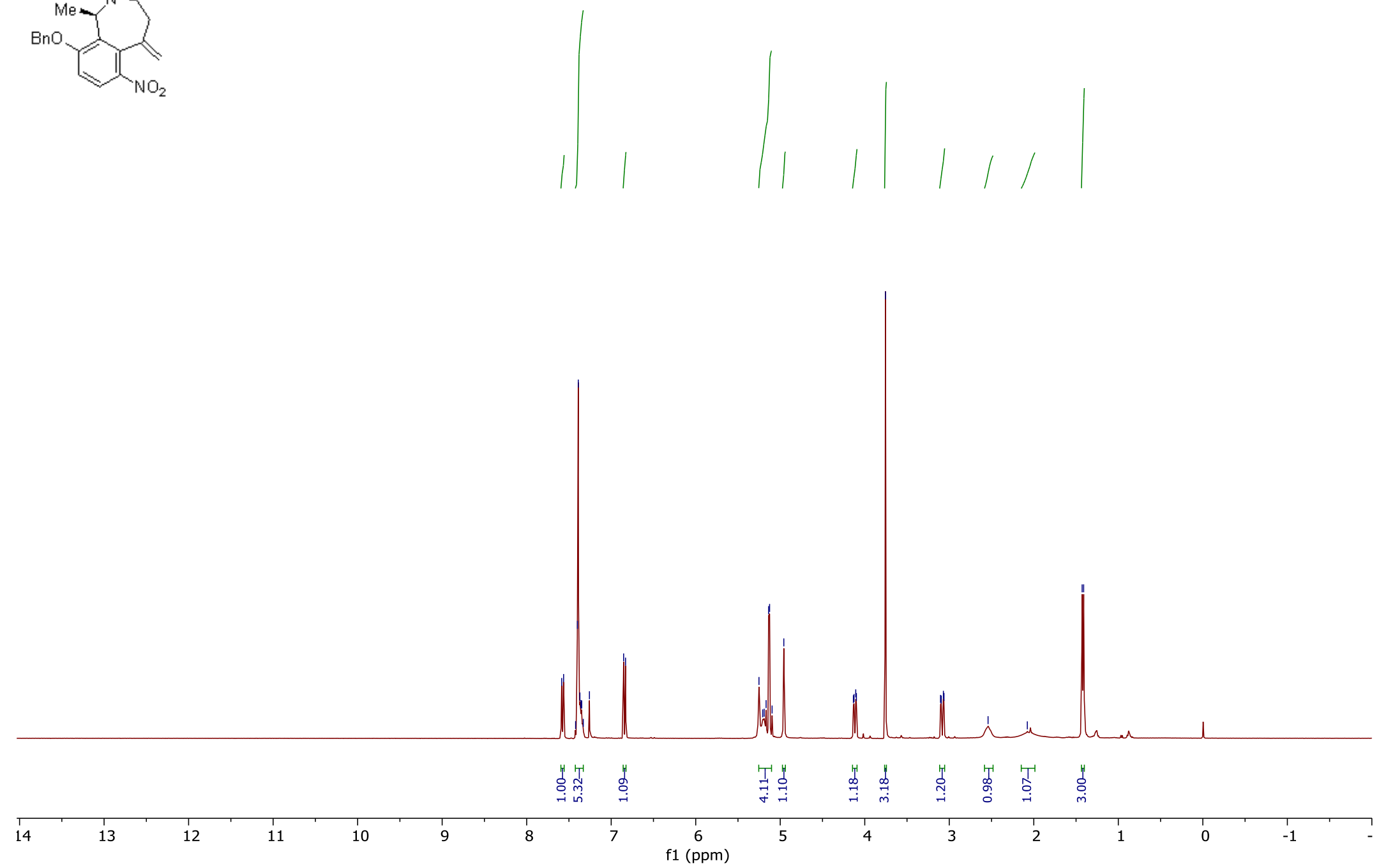

Figure 71: ${ }^{1} \mathrm{H}$ NMR of Compound 158 

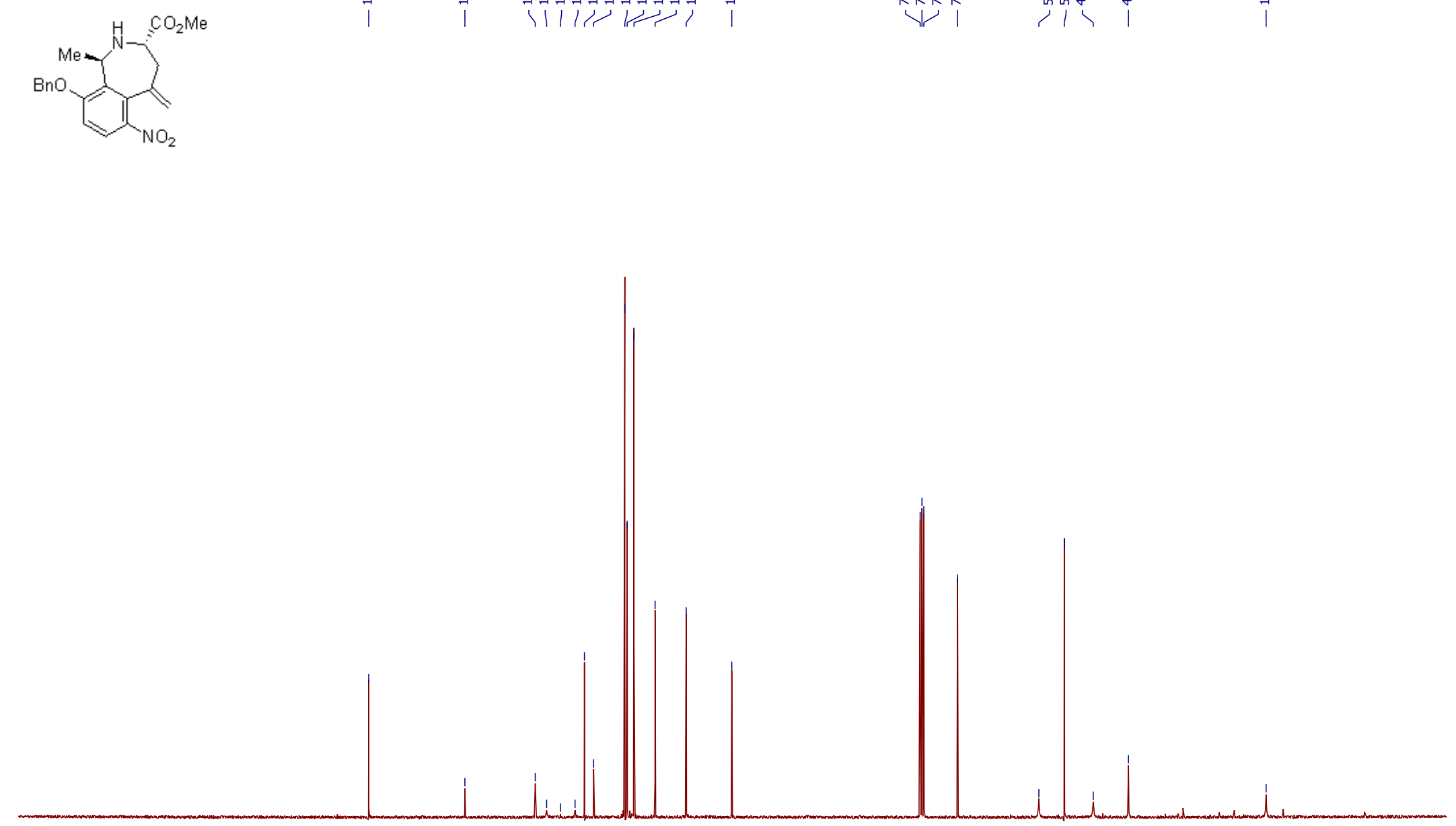

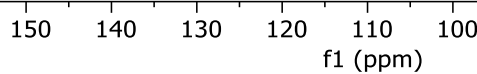

$80 \quad 70$

$60 \quad 50$

$40 \quad 30$

$\begin{array}{llll}1 & 10 & 0 & -10\end{array}$

Figure 72: ${ }^{13} \mathrm{C}$ NMR of Compound 158 


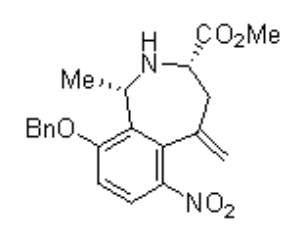

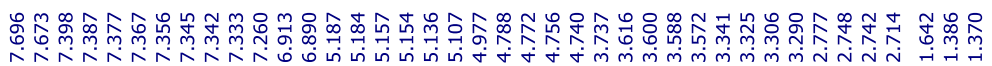
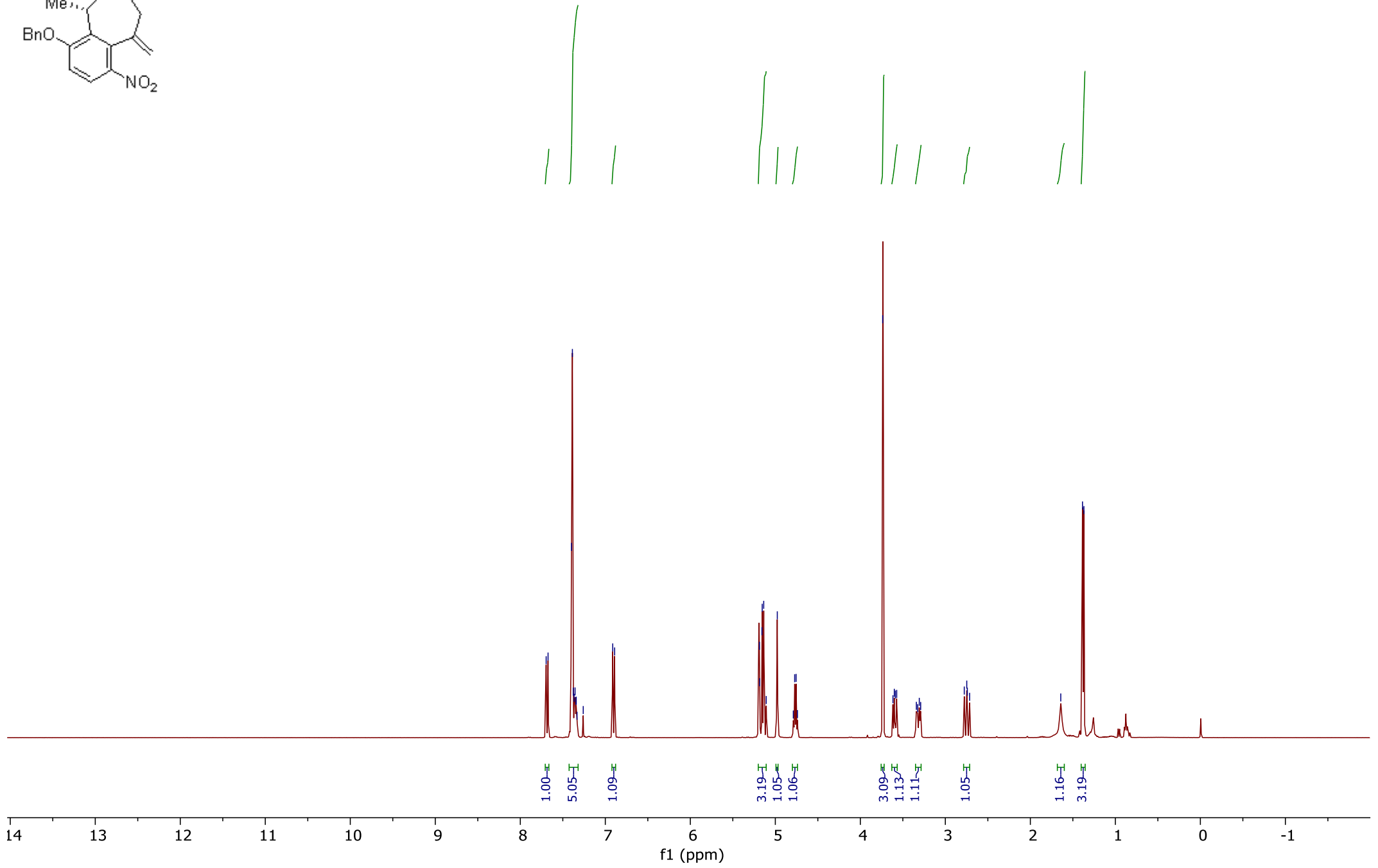

Figure 73: ${ }^{1} \mathrm{H}$ NMR of Compound 159 

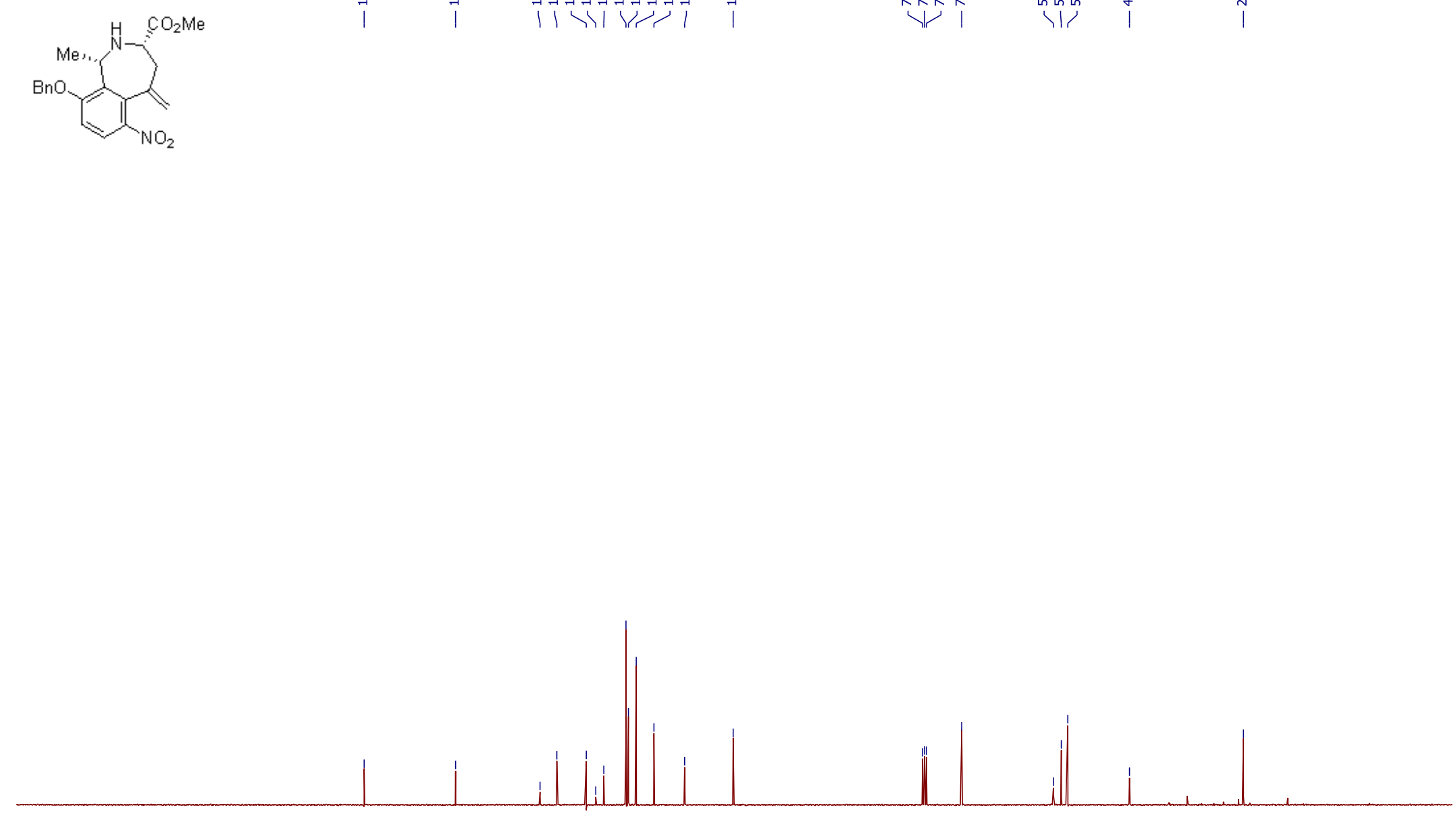

\begin{tabular}{lllllllllllllllllllllllllllllllll}
\hline & 130 & 220 & 210 & 200 & 190 & 180 & 170 & 160 & 150 & 140 & 130 & 120 & 110 & 100 & 90 & 80 & 70 & 60 & 50 & 40 & 30 & 20 & 10 & 0 & -10
\end{tabular}

Figure 74: ${ }^{13} \mathrm{C}$ NMR of Compound 159 


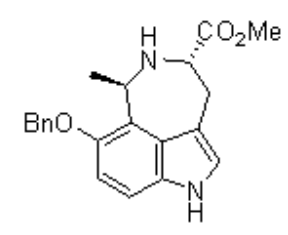

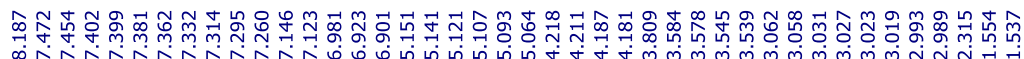

$\underline{4}$

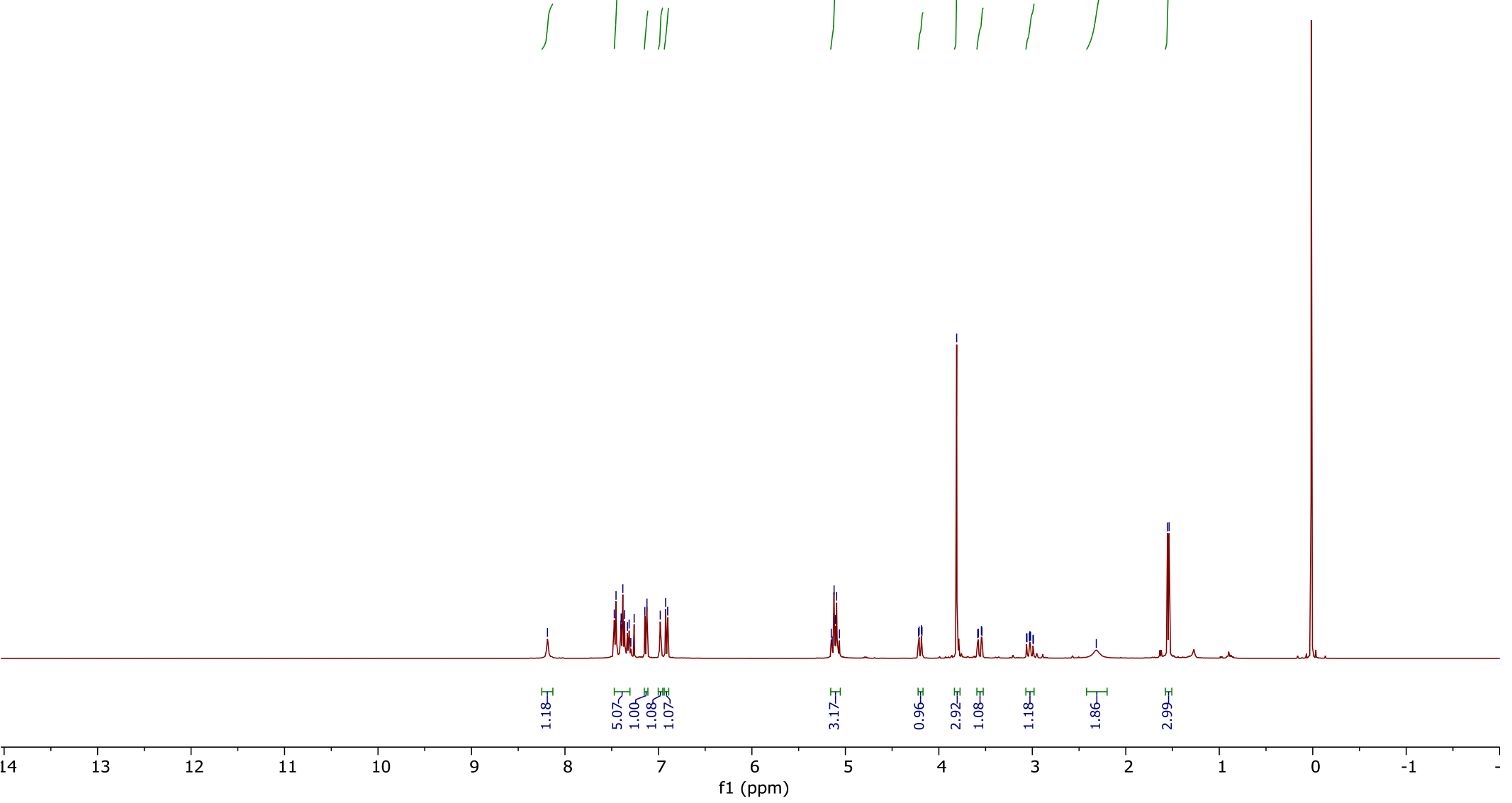

Figure 75: ${ }^{1} \mathrm{H}$ NMR of Compound 160 

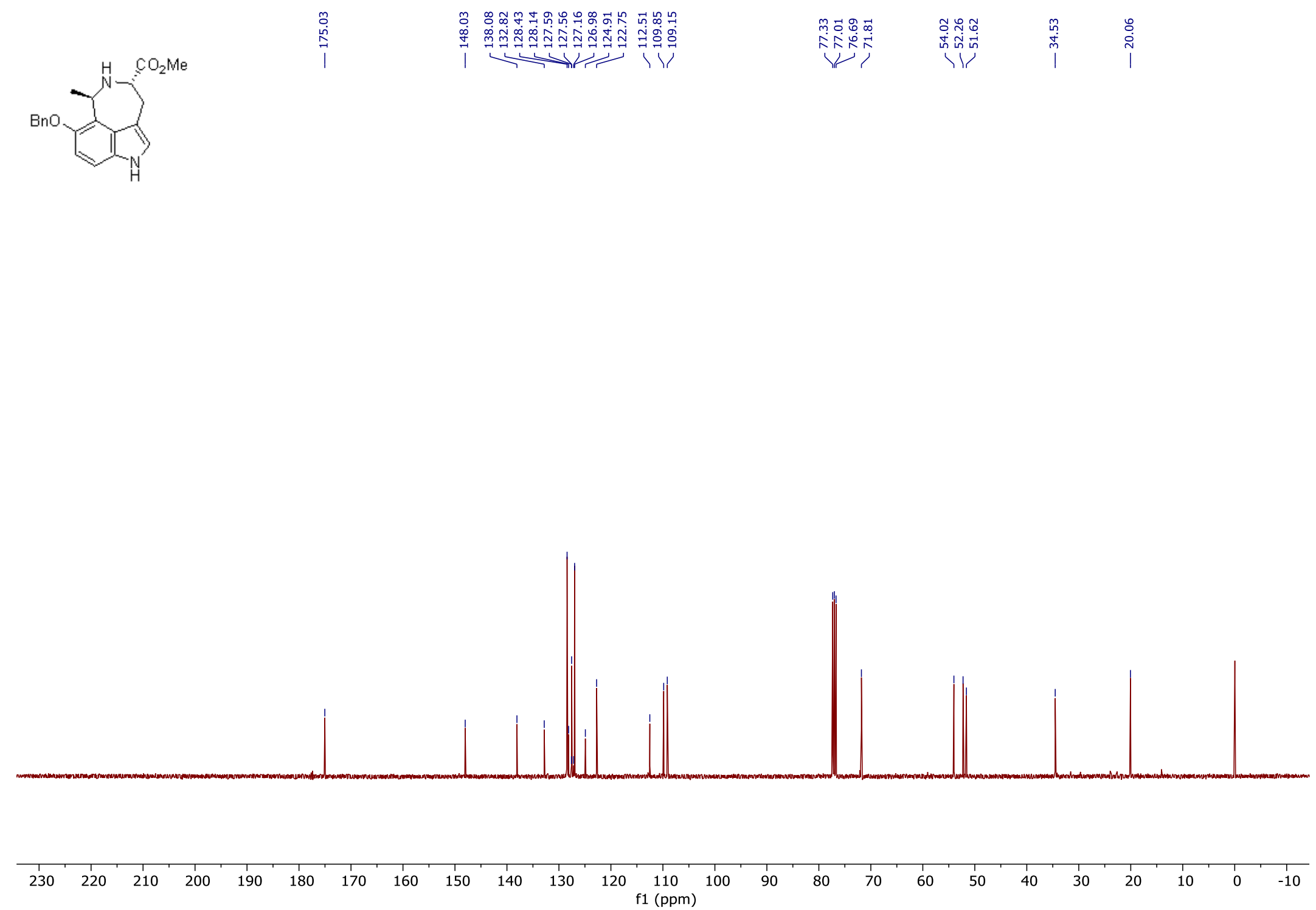

Figure 76: ${ }^{13} \mathrm{C}$ NMR of Compound 160 


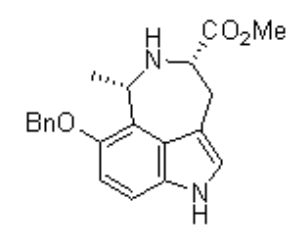

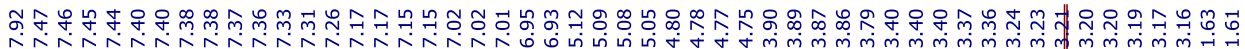
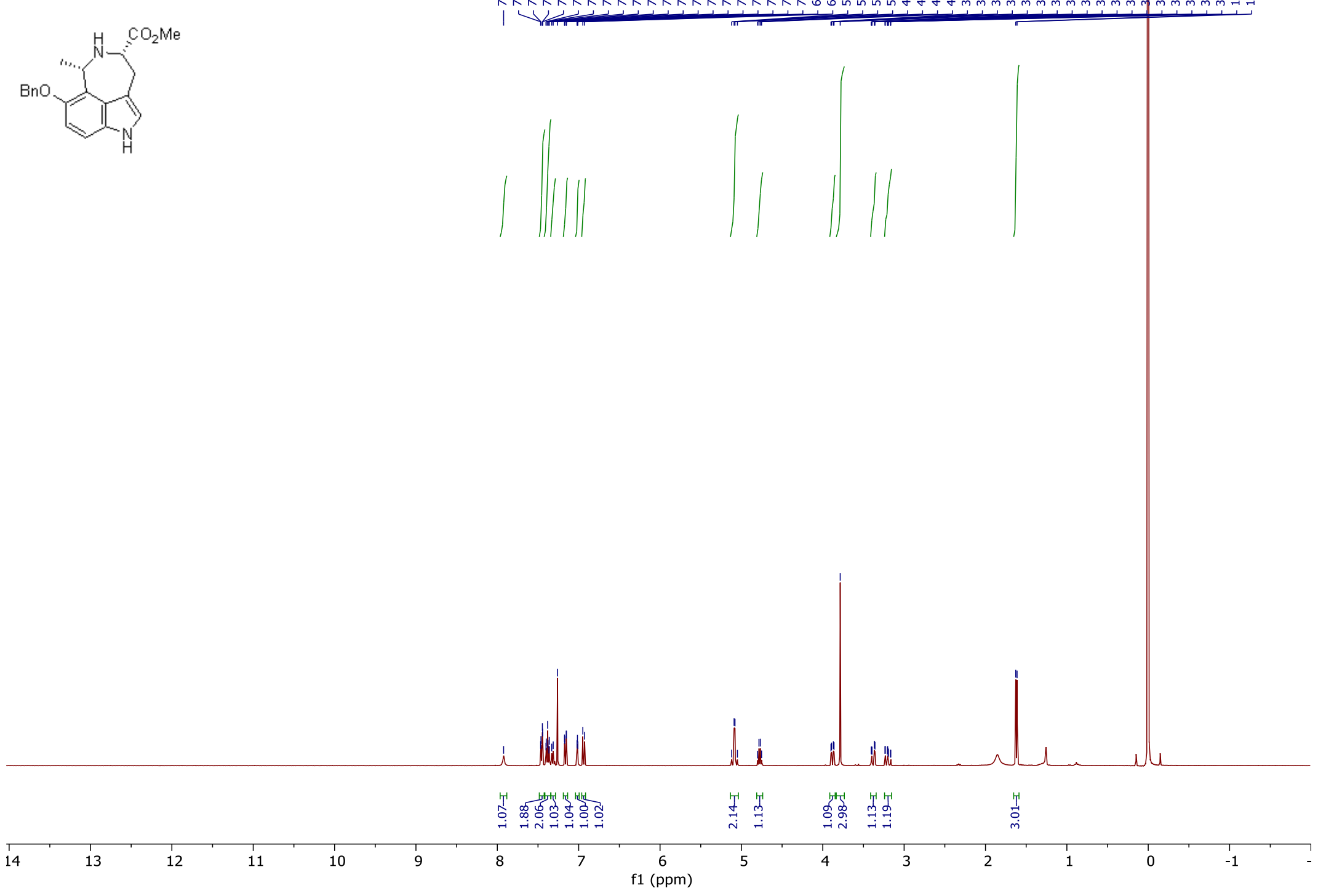

Figure 77: ${ }^{1} \mathrm{H}$ NMR of Compound 161 

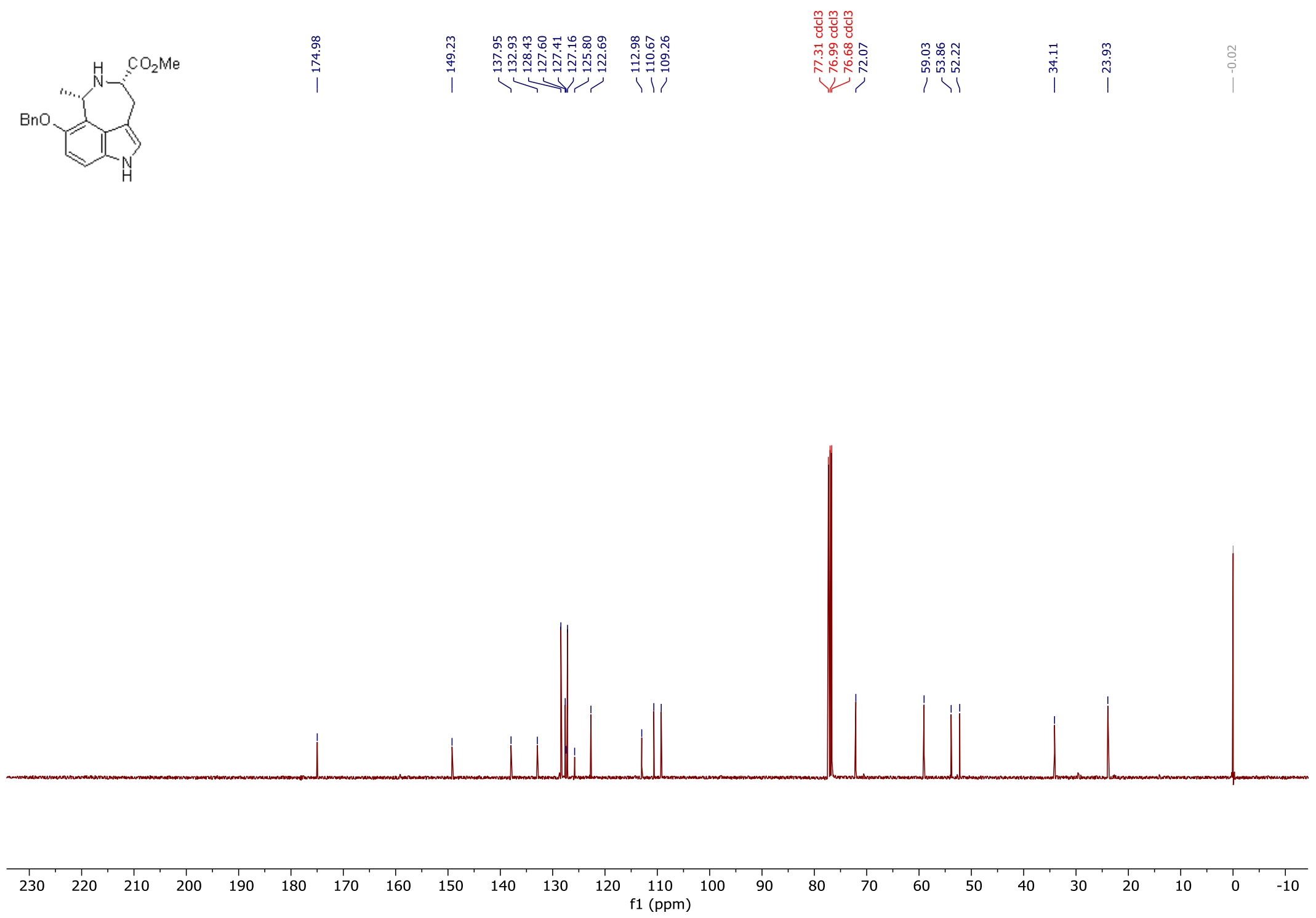

Figure 78: ${ }^{13} \mathrm{C}$ NMR of Compound $\mathbf{1 6 1}$

160 


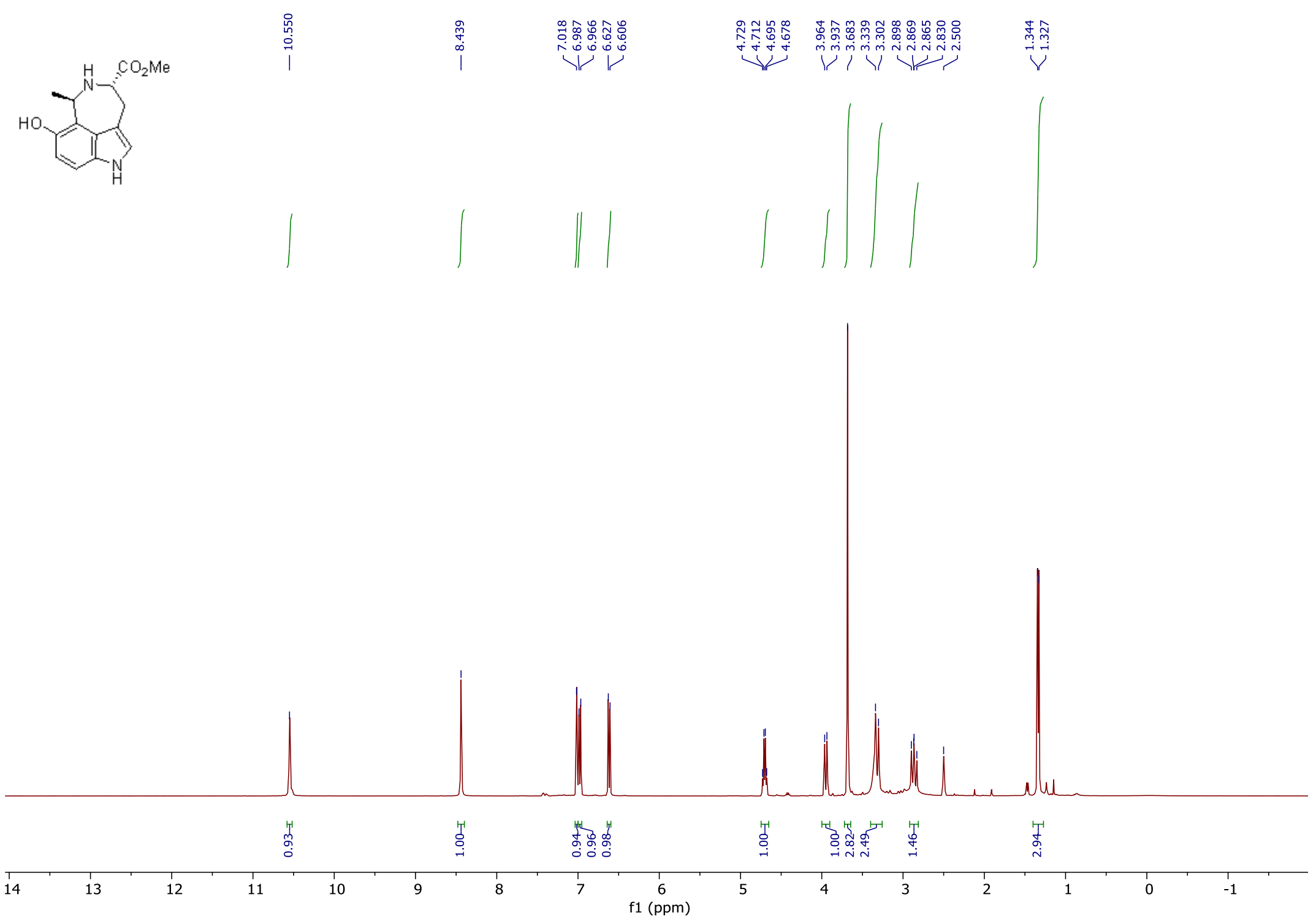

Figure 79: ${ }^{1} \mathrm{H}$ NMR of Compound 164 

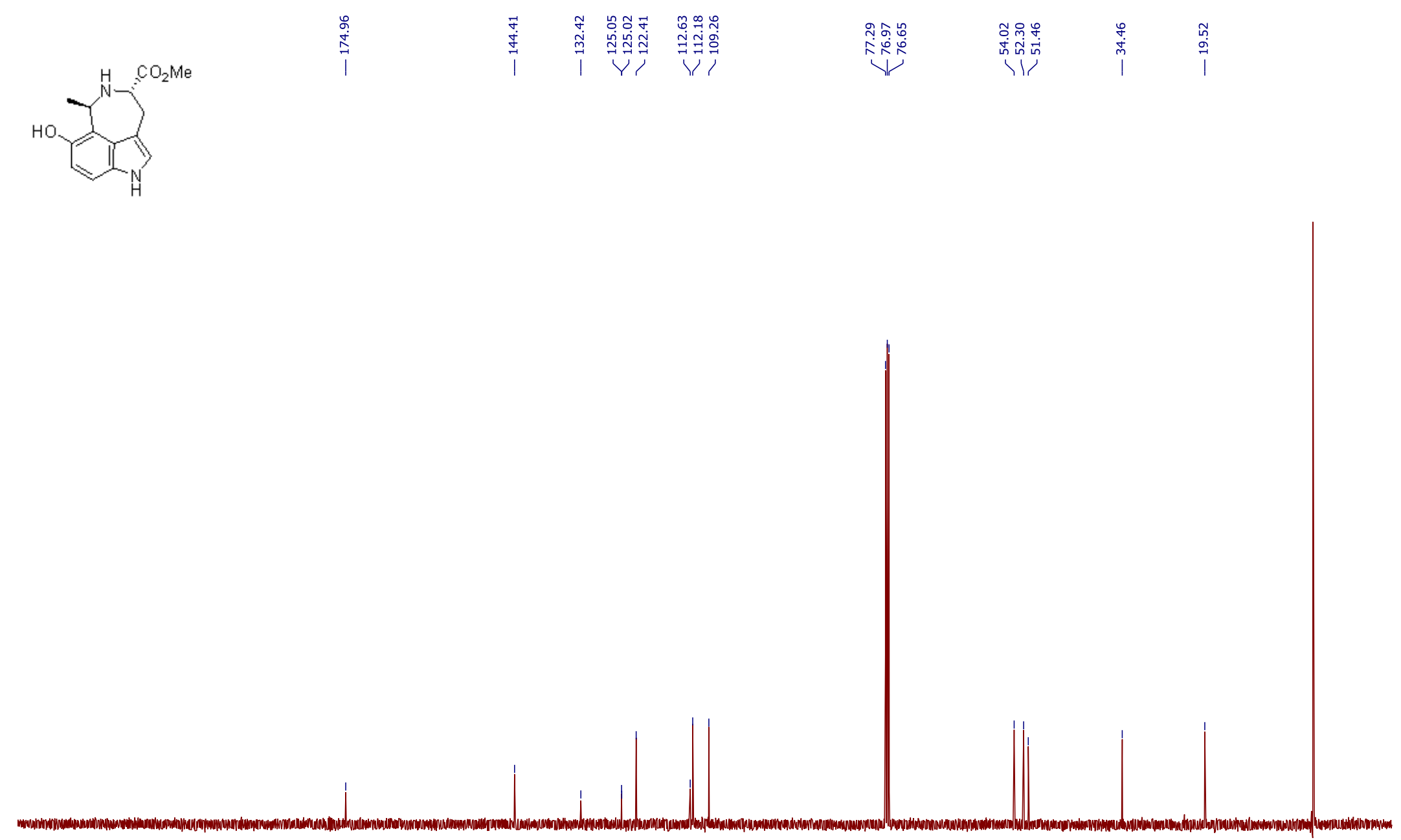

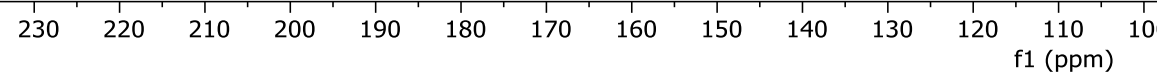

$80 \quad 70$

$60 \quad 50$

$40 \quad 30$

$20 \quad 10 \quad 0 \quad-10$

Figure 80: ${ }^{13} \mathrm{C}$ NMR of Compound 164 


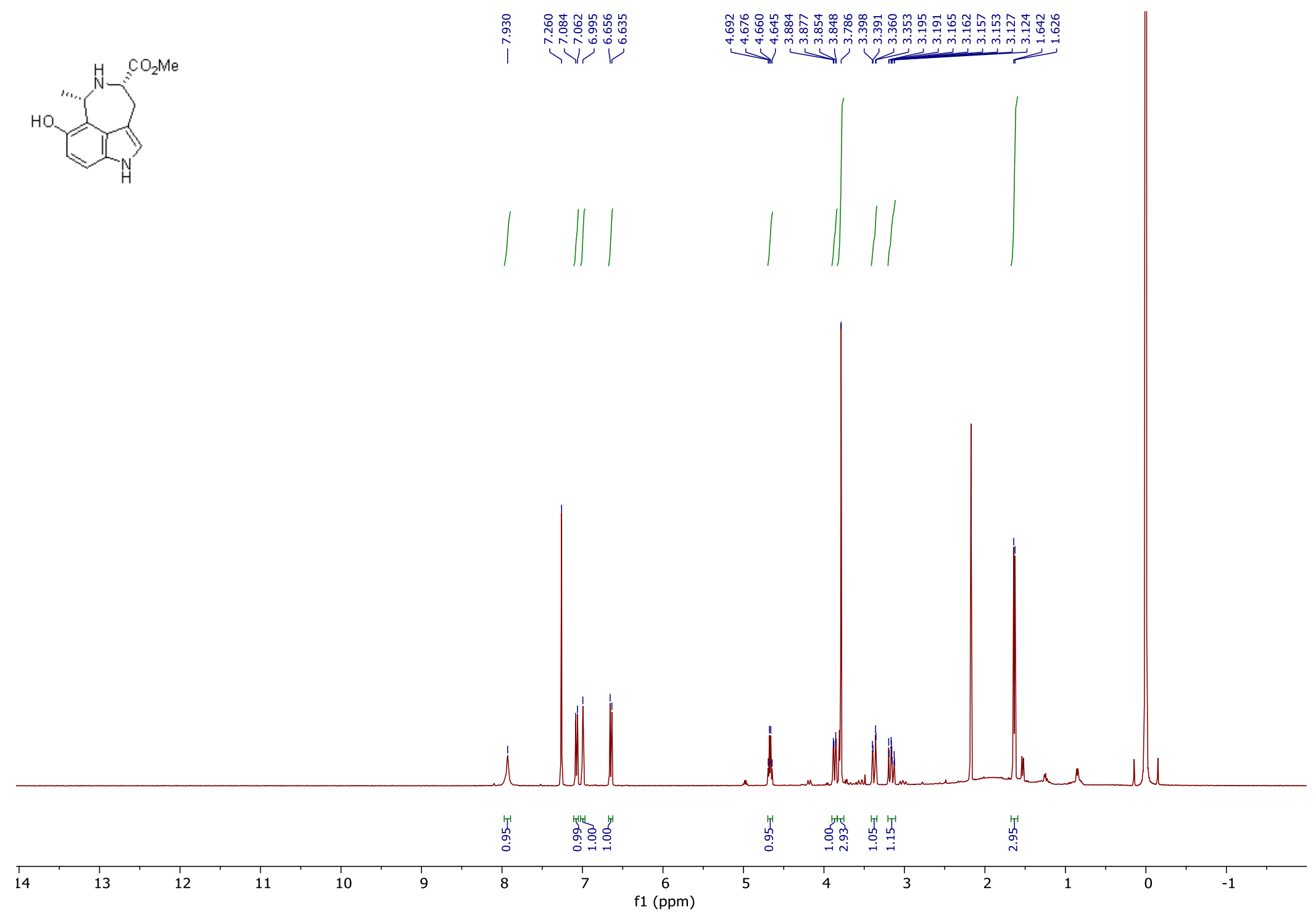

Figure 81: ${ }^{1} \mathrm{H}$ NMR of Compound 165 

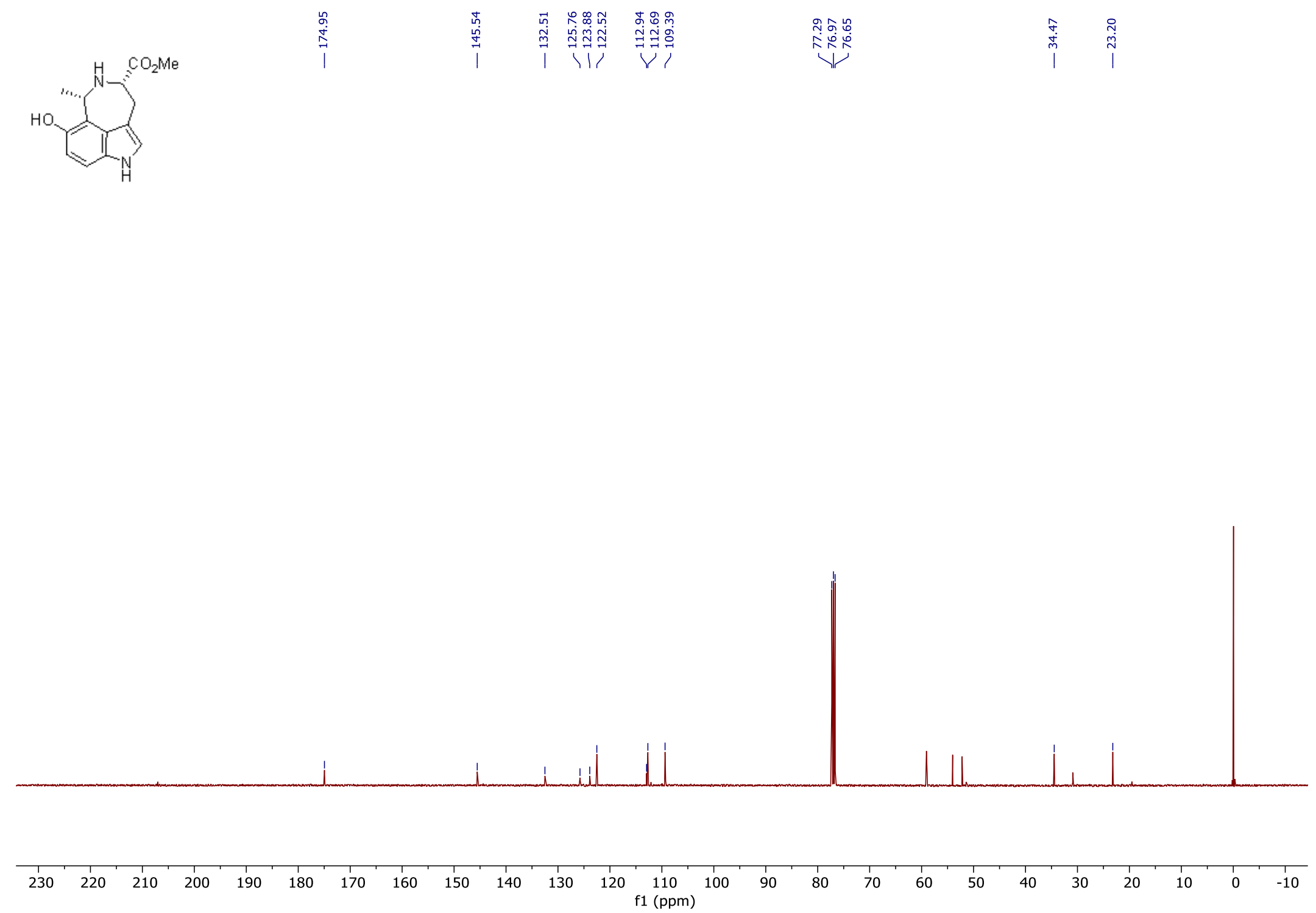

Figure 82: ${ }^{13} \mathrm{C}$ NMR of Compound 165 
${ }^{1} \mathrm{H}$ and ${ }^{13} \mathrm{C}$ NMR for Chapter 4: Aurantioclavine

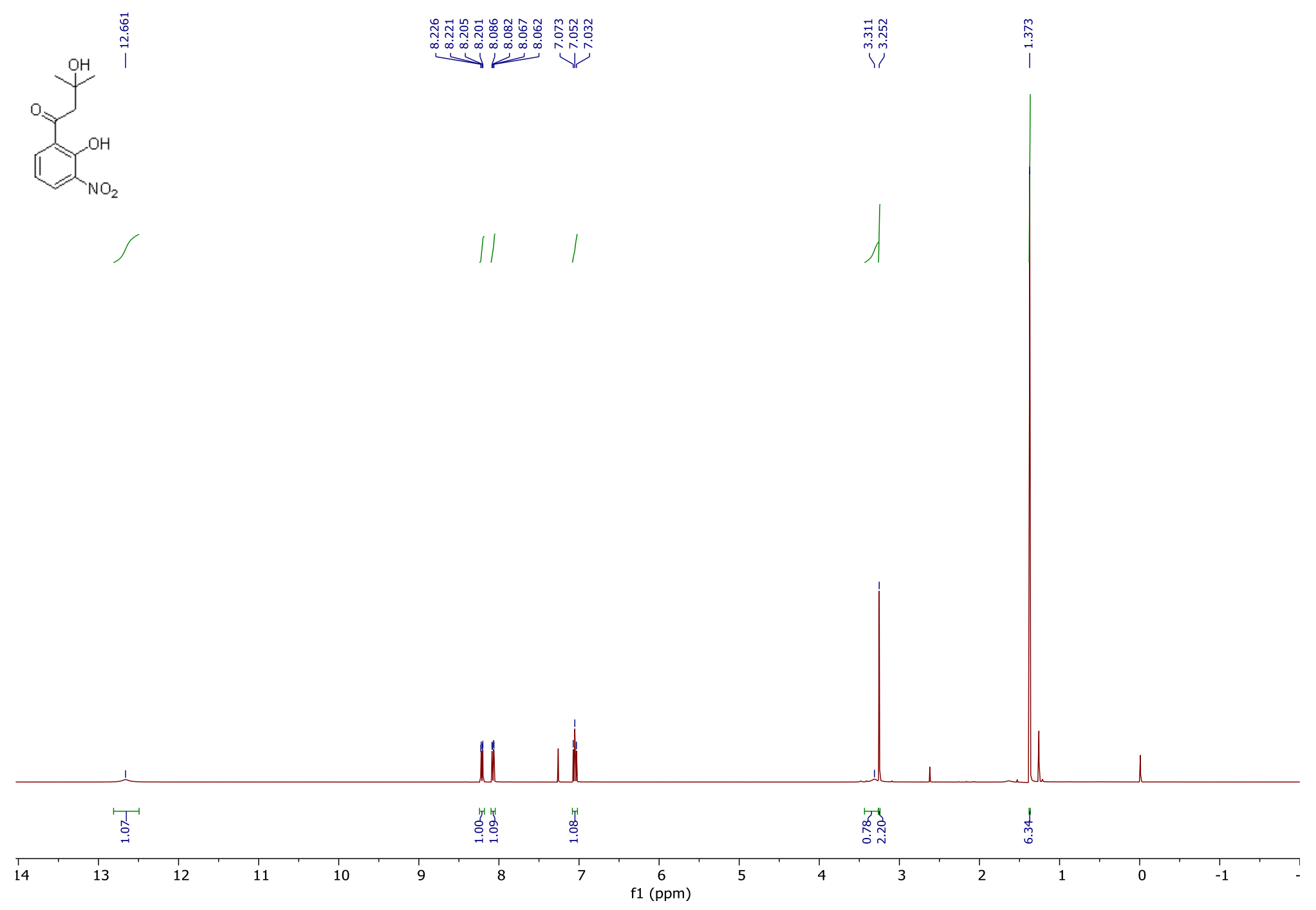

Figure 83: ${ }^{1} \mathrm{H}$ NMR of Compound 200 

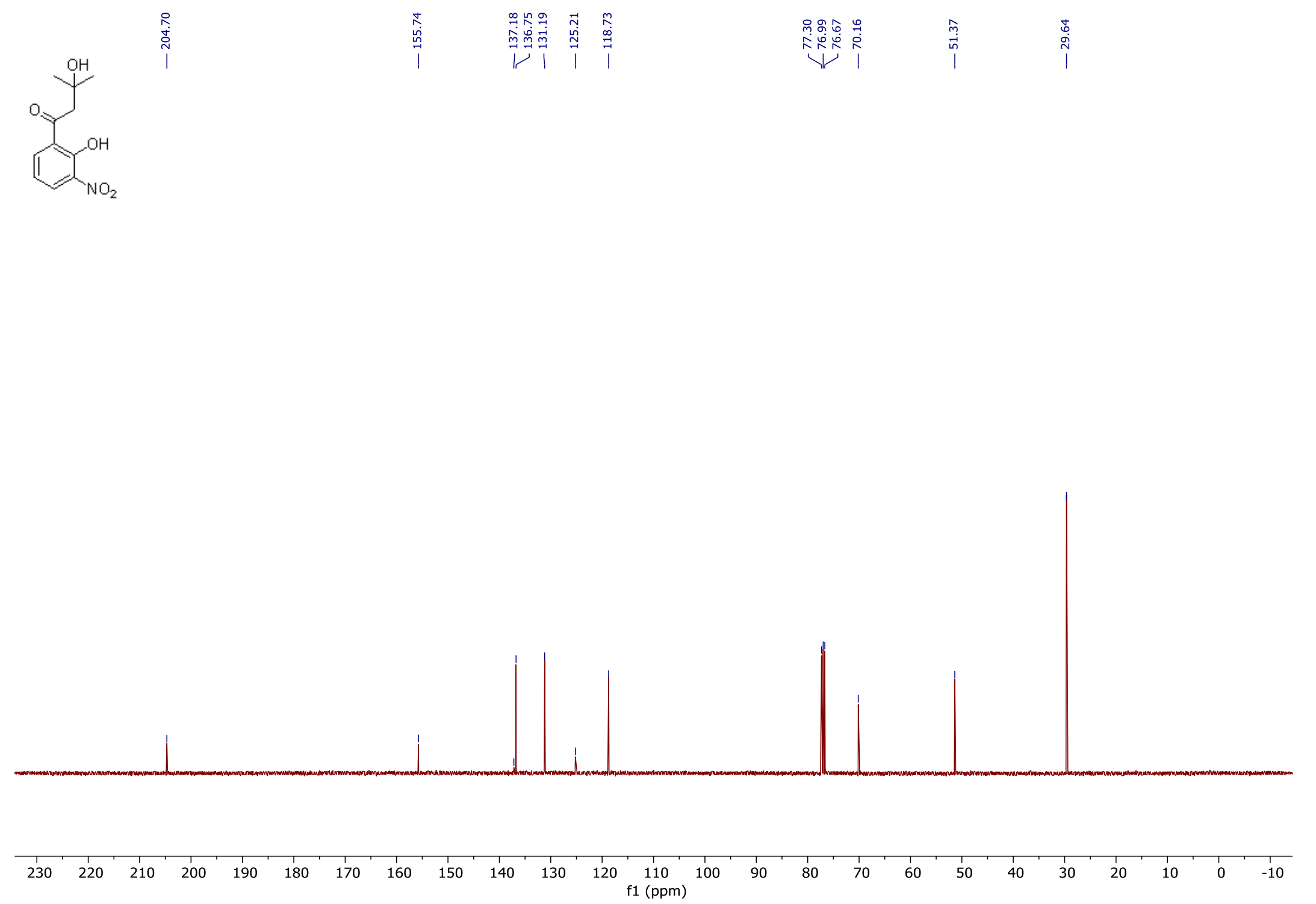

Figure 84: ${ }^{13} \mathrm{C}$ NMR of Compound 200 


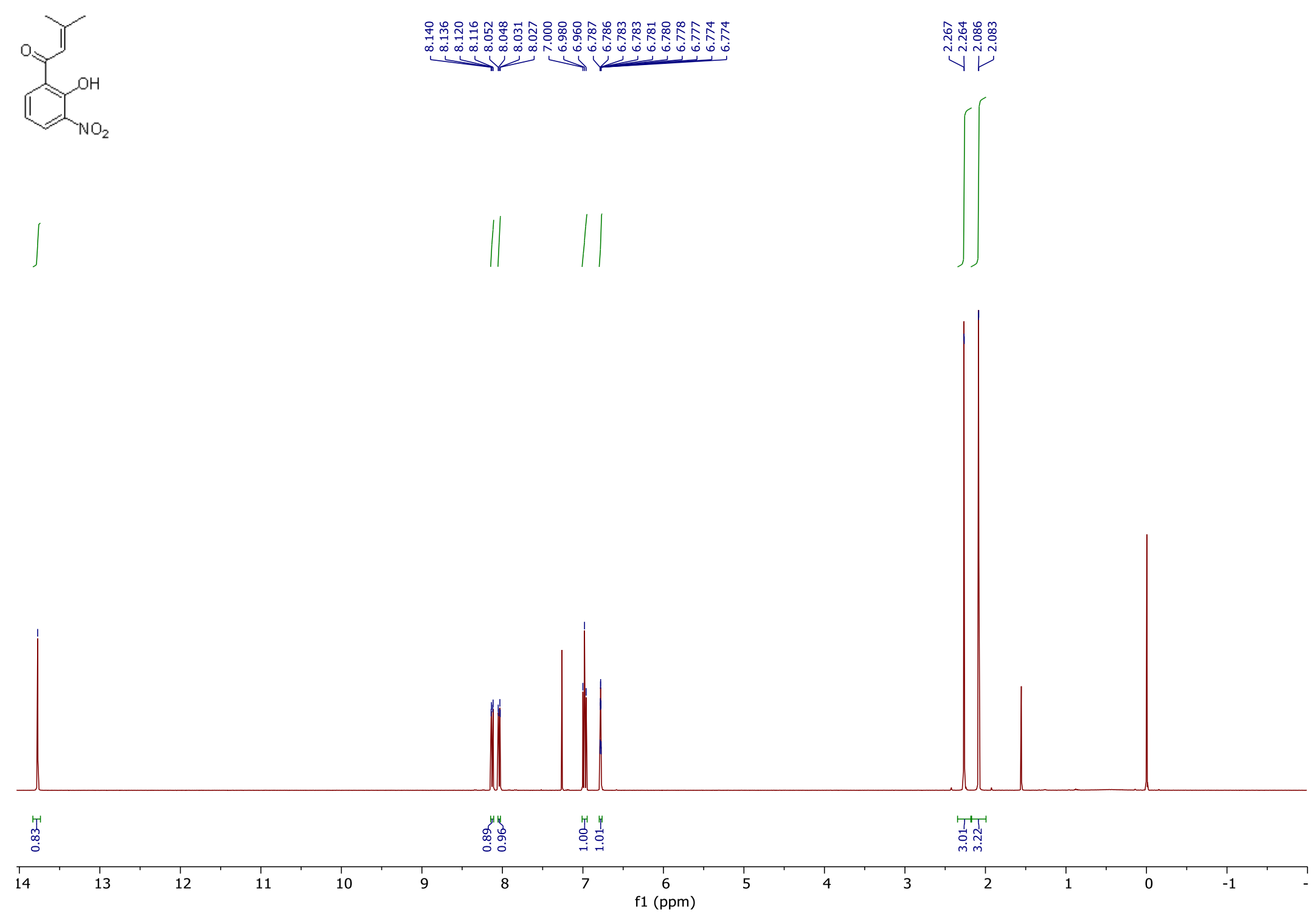

Figure 85: ${ }^{1} \mathrm{H}$ NMR of Compound 201 


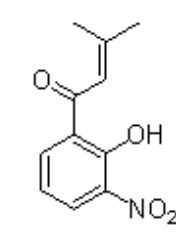

卓

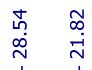

$\mathrm{NO}_{2}$

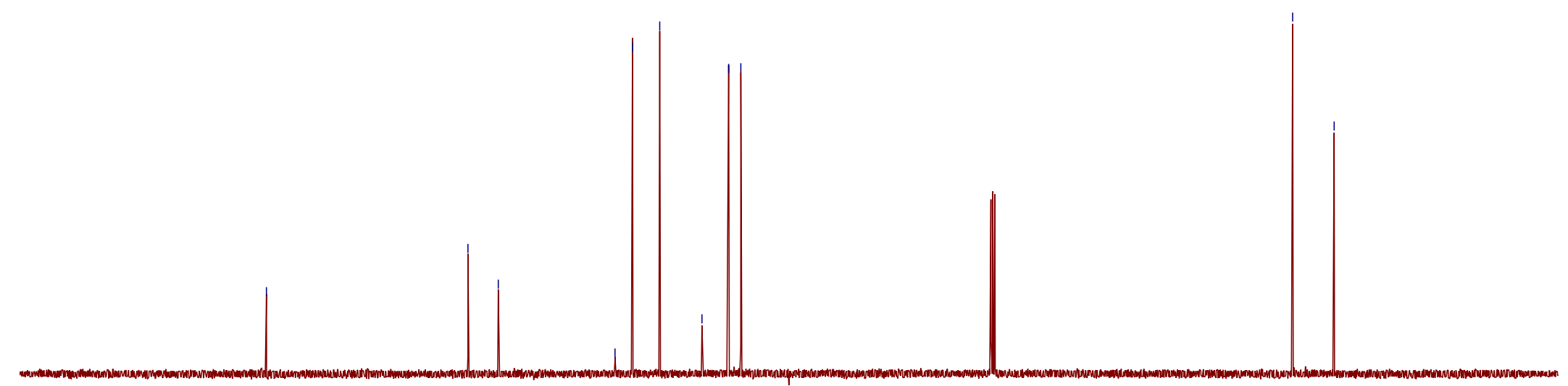

\begin{tabular}{llllllllllllllllllllllllllll}
\hline & 230 & 220 & 210 & 200 & 190 & 180 & 170 & 160 & 150 & 140 & 130 & 120 & 110 & 100 & 90 & 80 & 70 & 60 & 50 & 40 & 30 & 20 & 10 & 0 & -10
\end{tabular}

Figure 86: ${ }^{13} \mathrm{C}$ NMR of Compound 201 

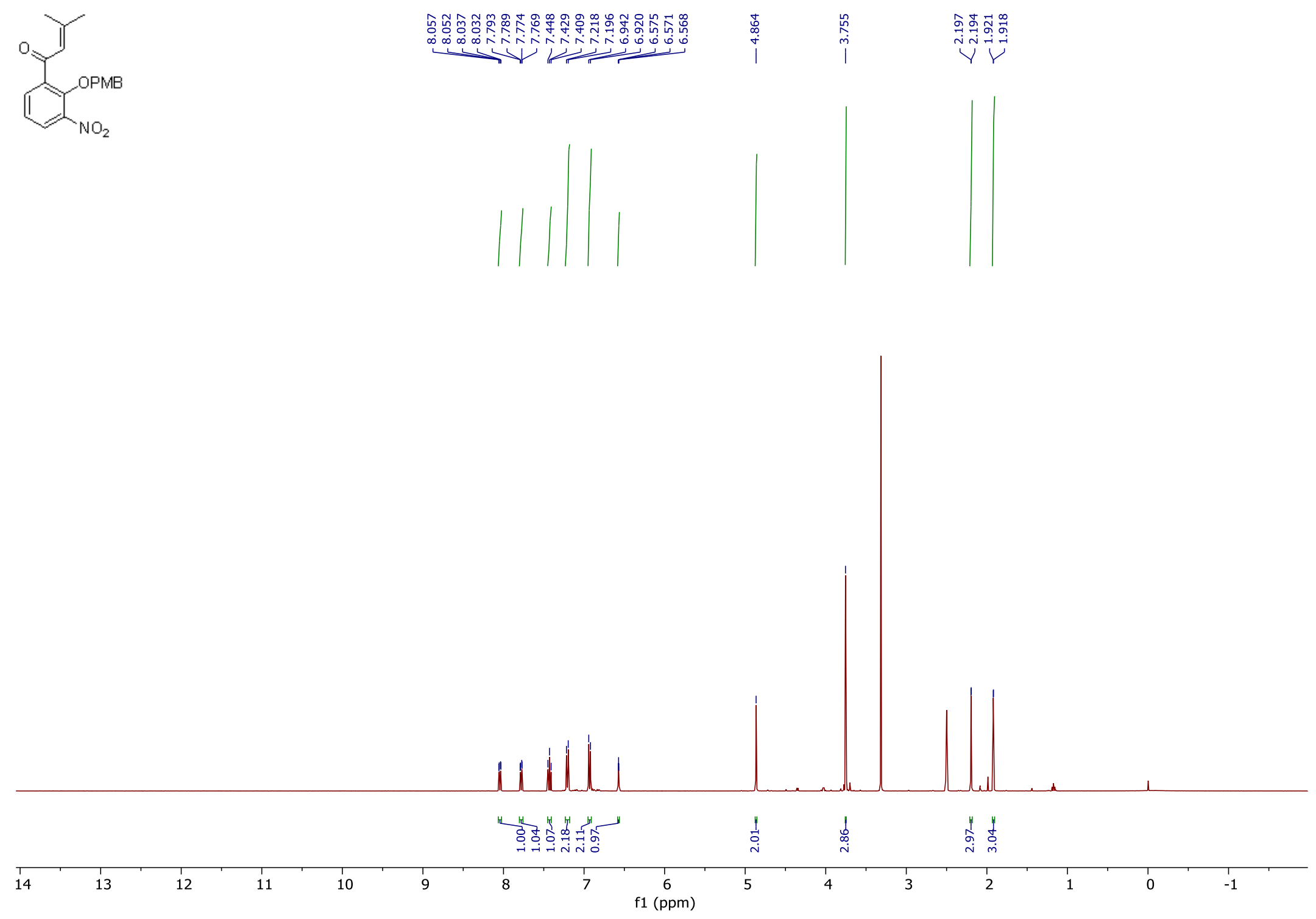

Figure 87: ${ }^{1} \mathrm{H}$ NMR of Compound 203 

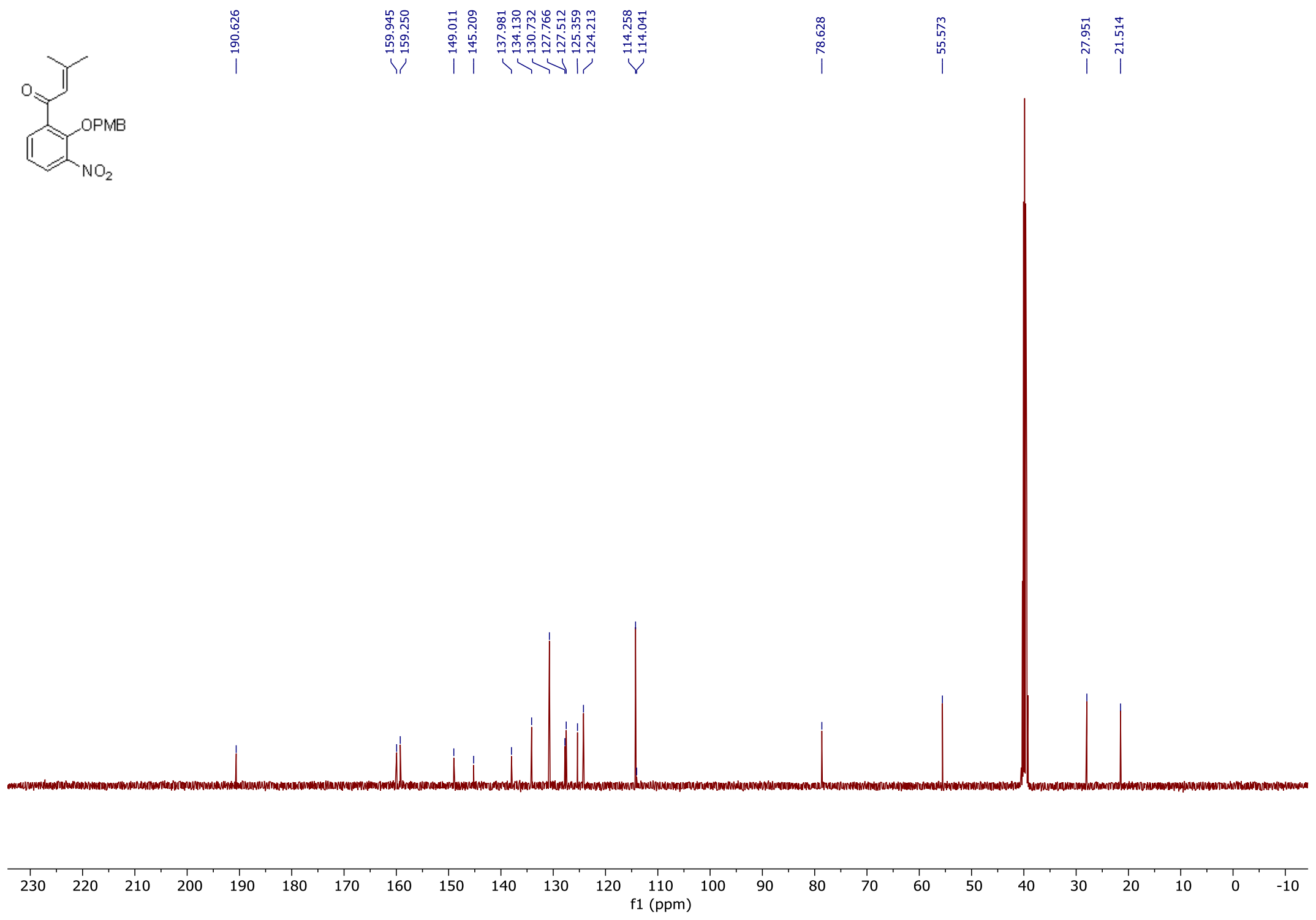

Figure 88: ${ }^{13} \mathrm{C}$ NMR of Compound 203

170 


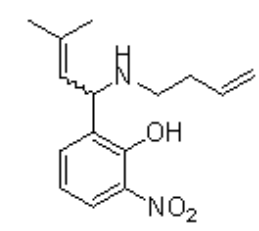

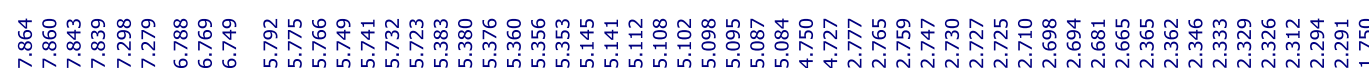

N V U

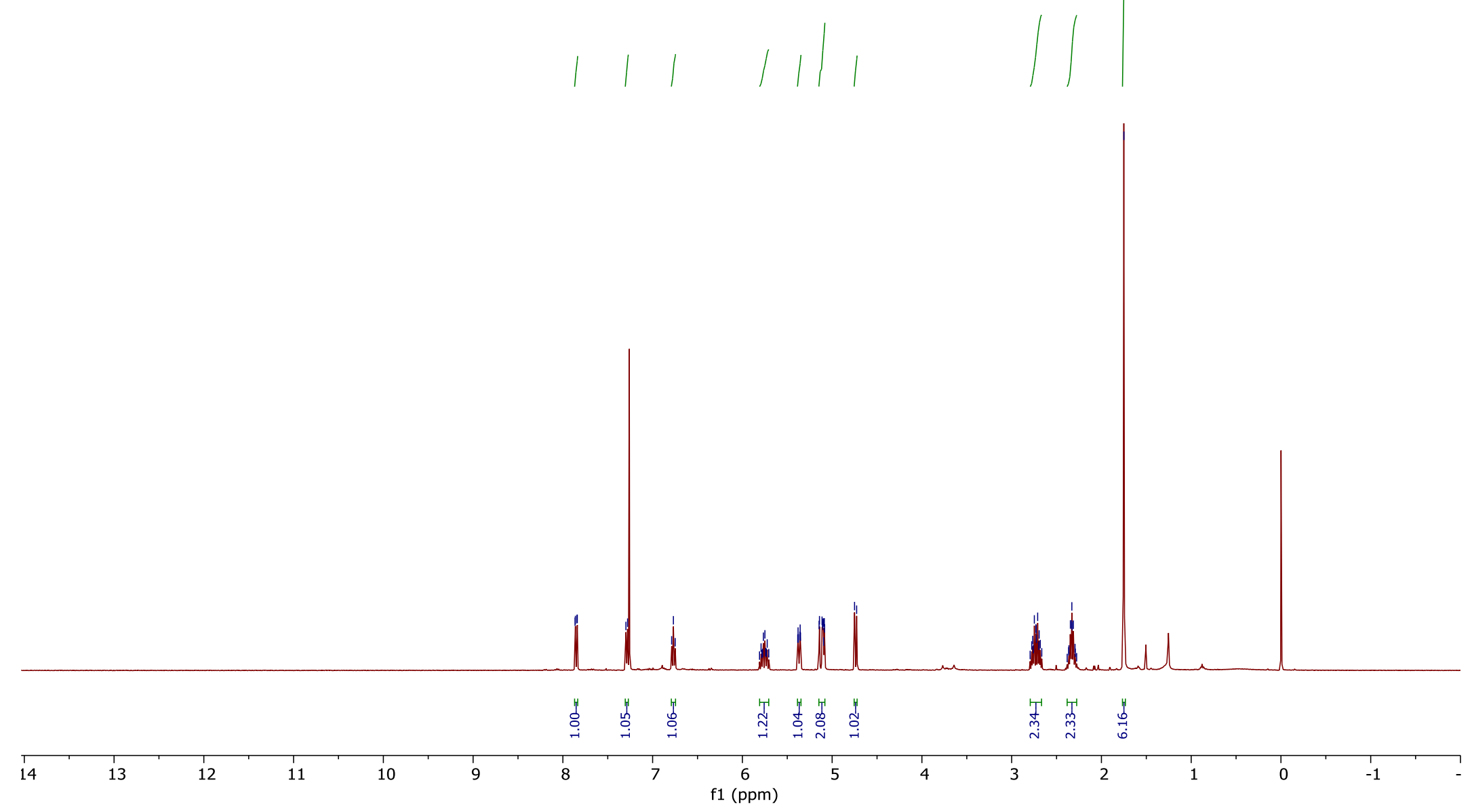

Figure 89: ${ }^{1} \mathrm{H}$ NMR of Compound $\mathbf{2 0 5}$ 


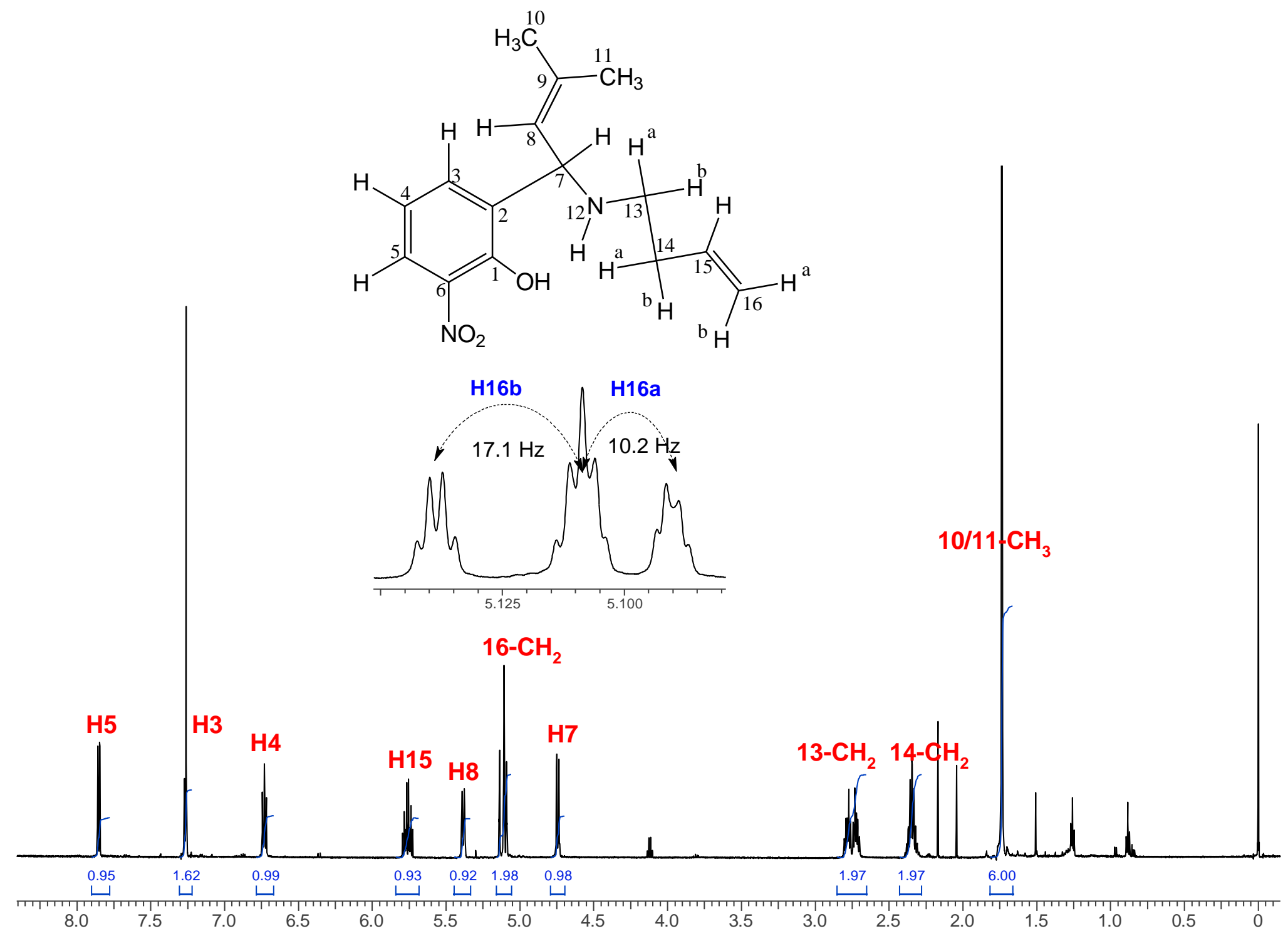

Figure 90: ${ }^{1} \mathrm{H}$ NMR of Compound 205 


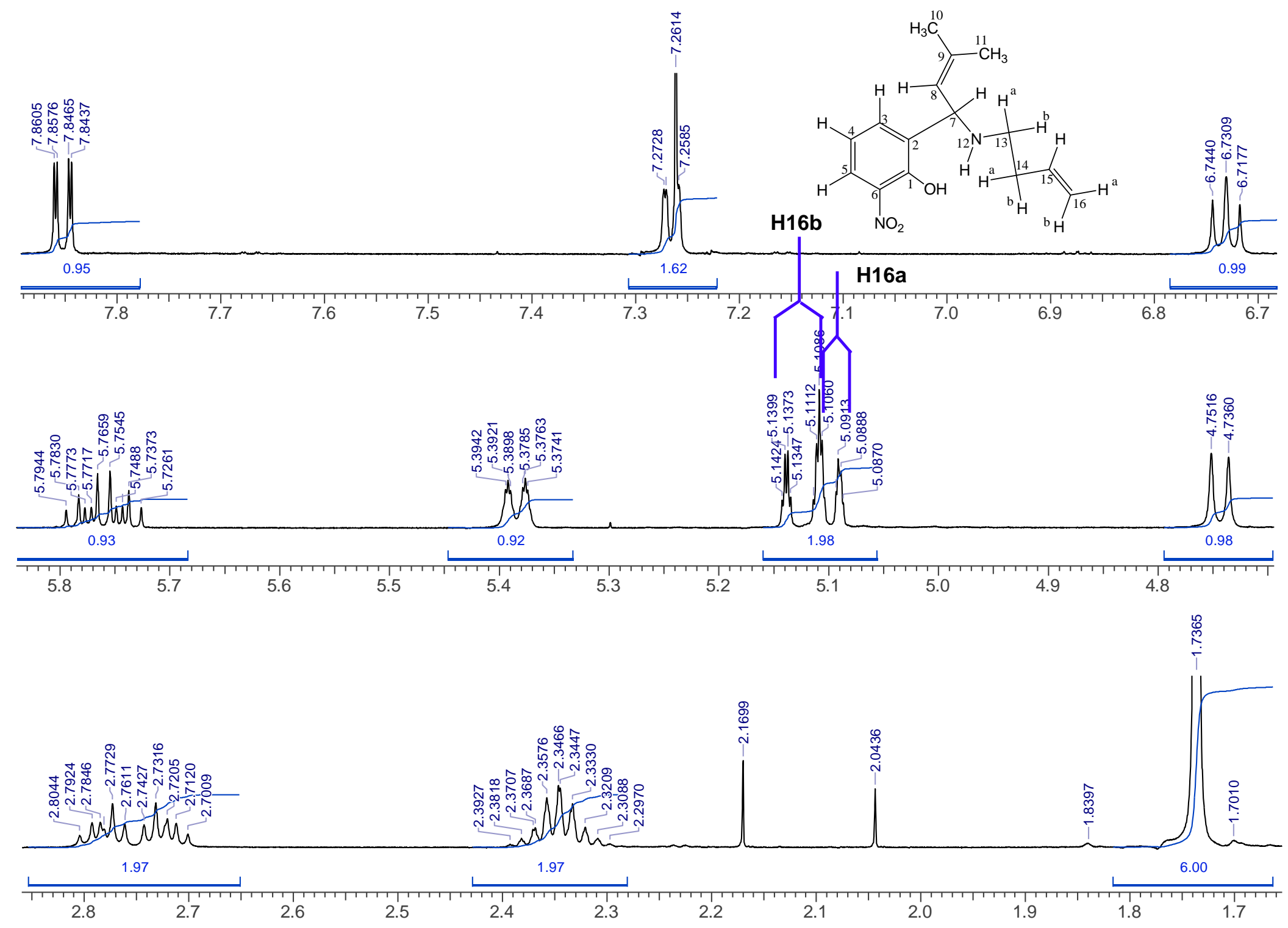

Figure 91: ${ }^{1} \mathrm{H}$ NMR of Compound 205 


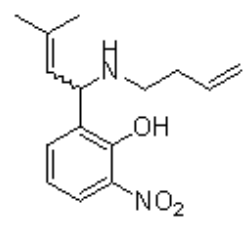

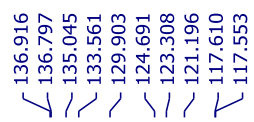
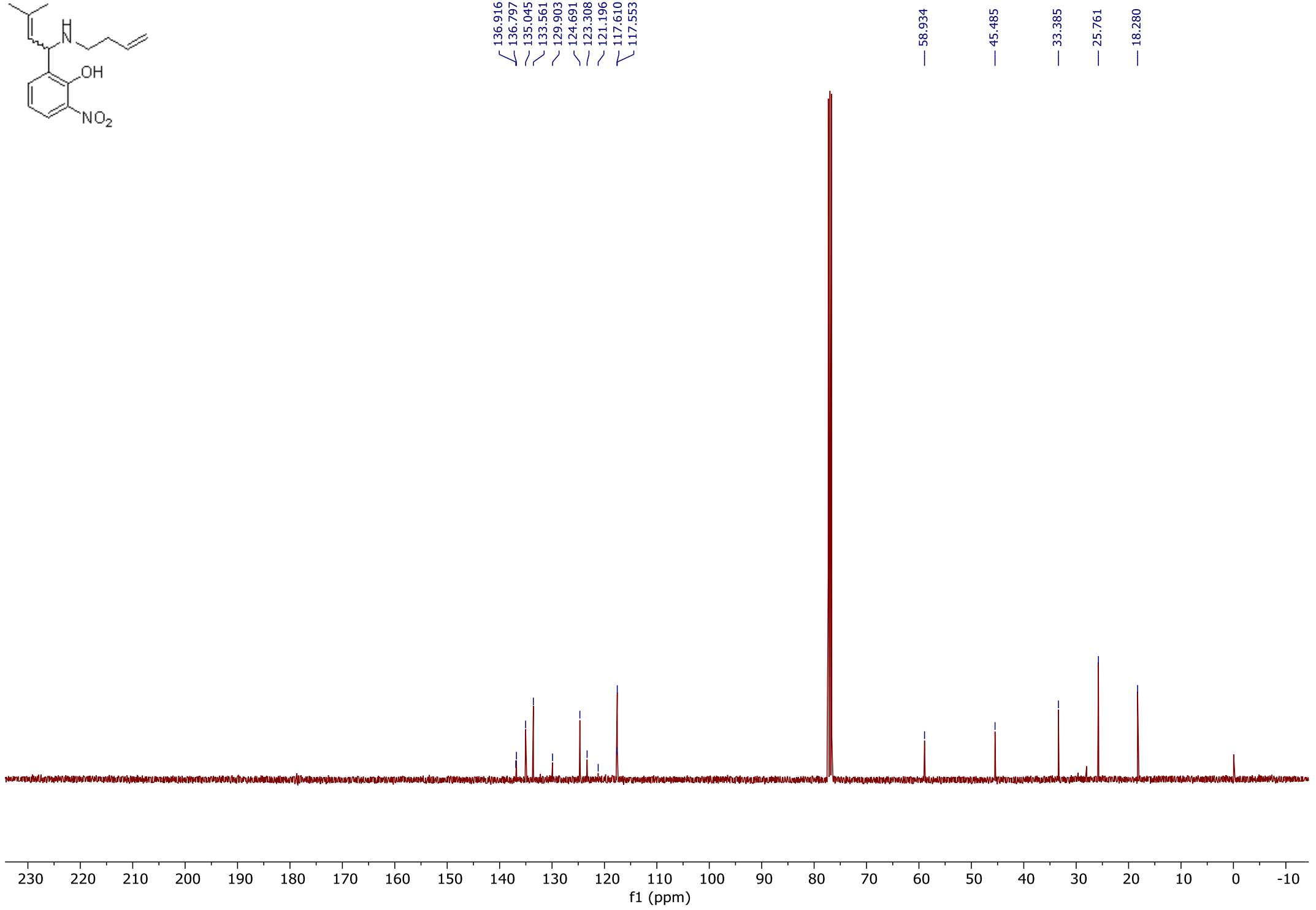

Figure 92: ${ }^{13} \mathrm{C}$ NMR of Compound 205

174 


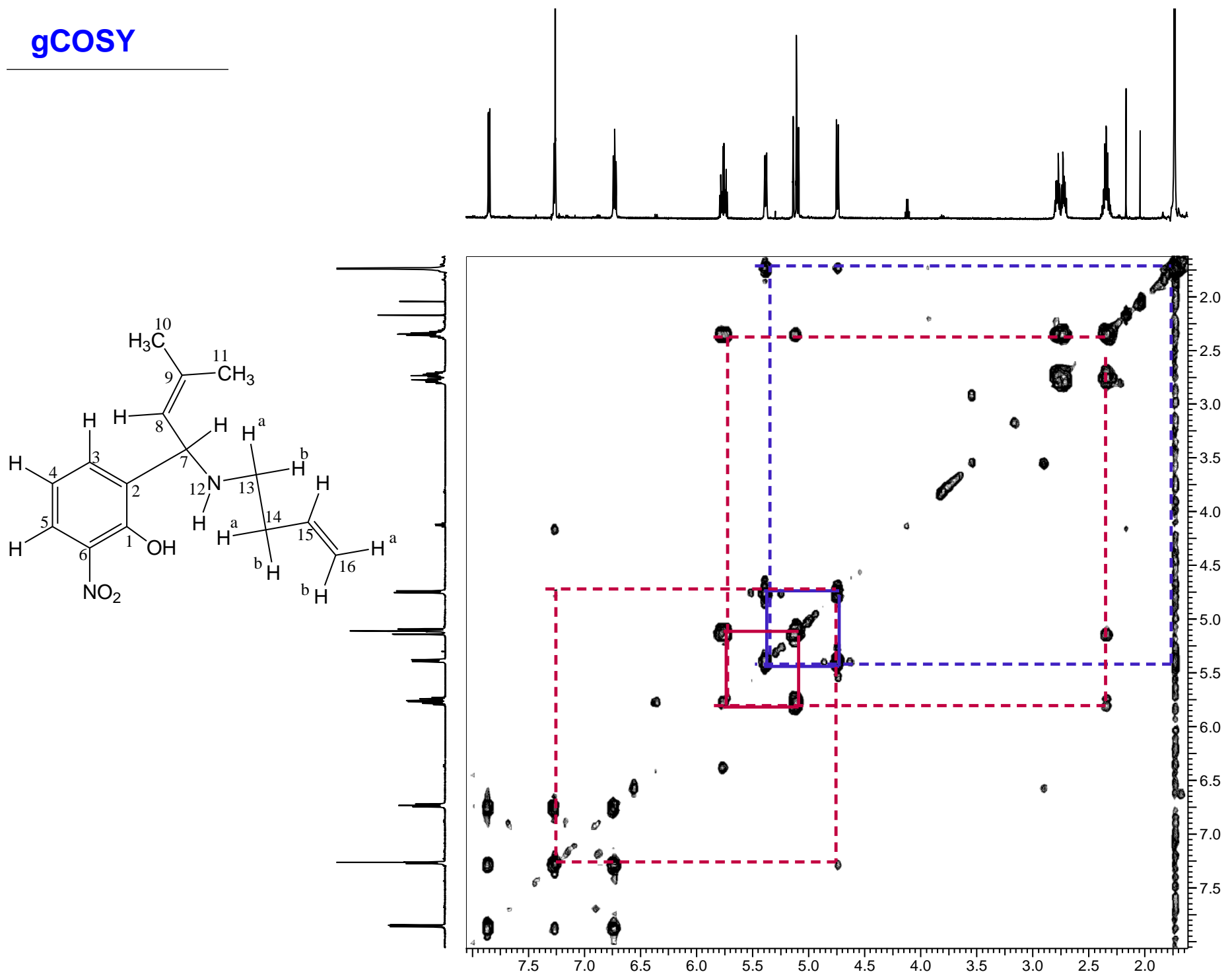

Figure 93: COSY of Compound 205 

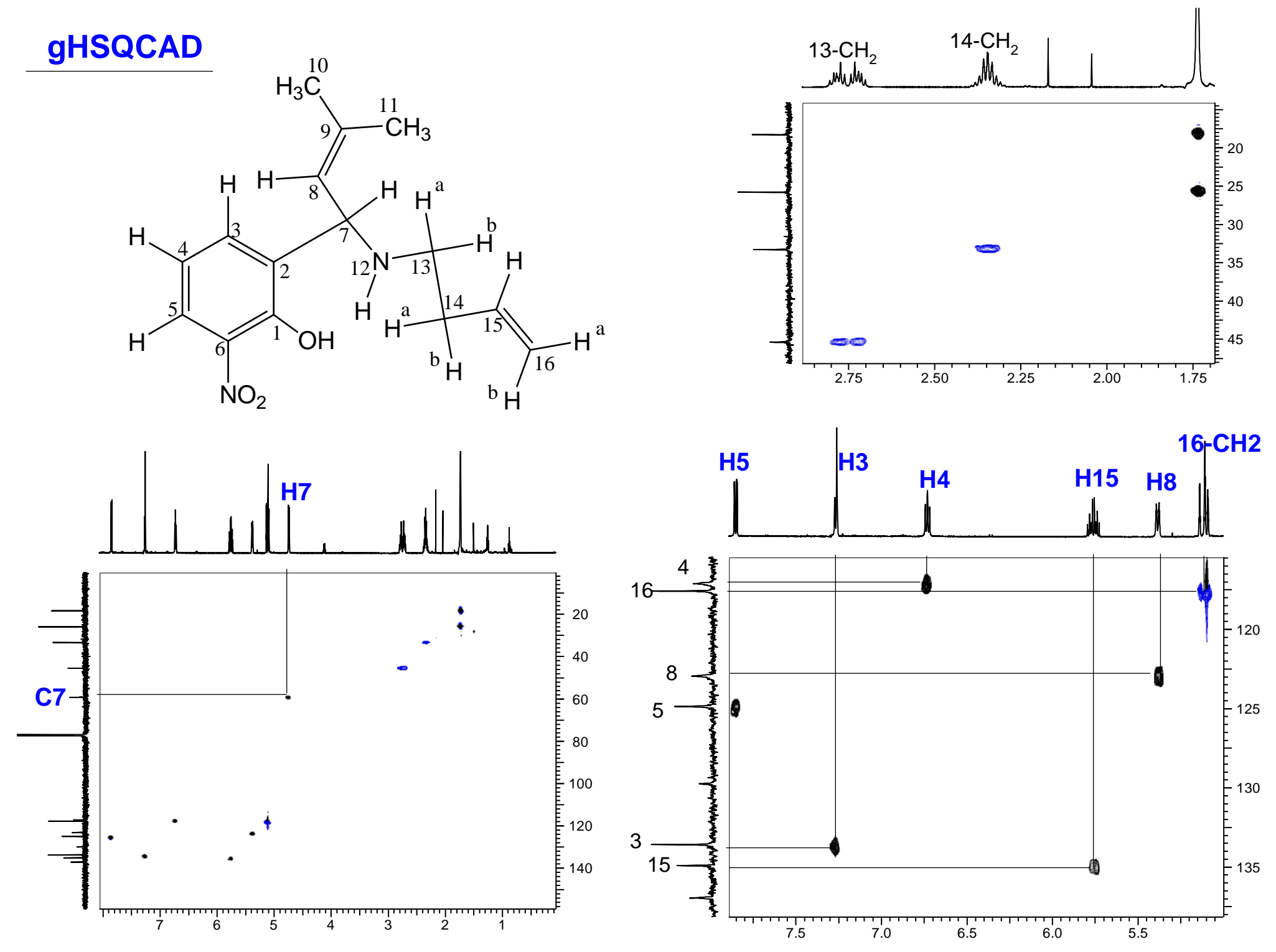

Figure 94: HSQC of Compound 205 


\section{DPFGSENOE}

subspectra

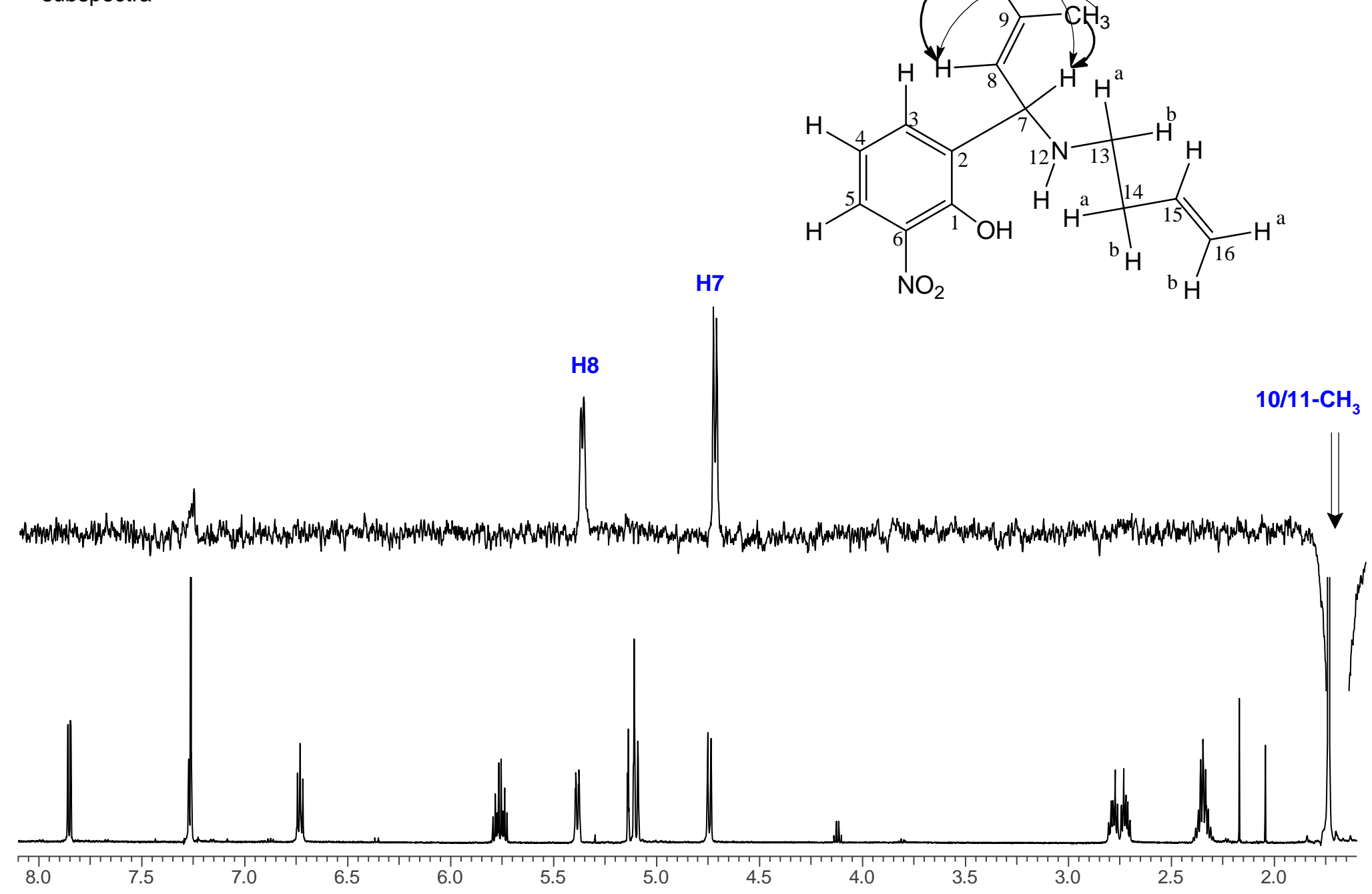

Figure 95: NOE of Compound 205 


\section{DPFGSENOE}

subspectra

H3

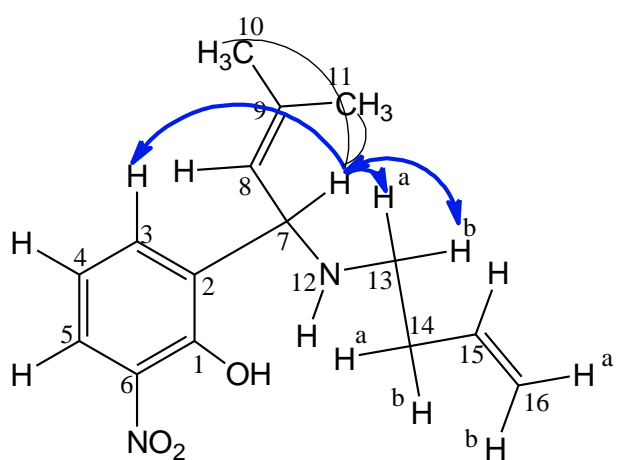

10/11- $\mathrm{CH}_{3}$

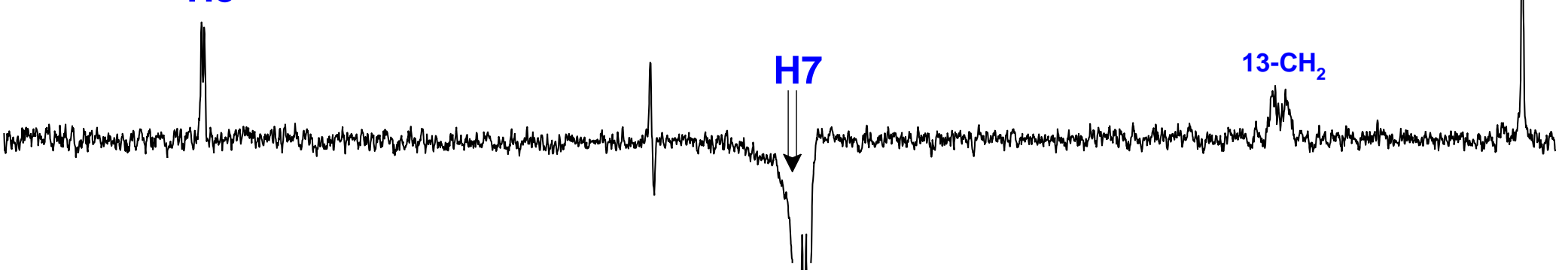

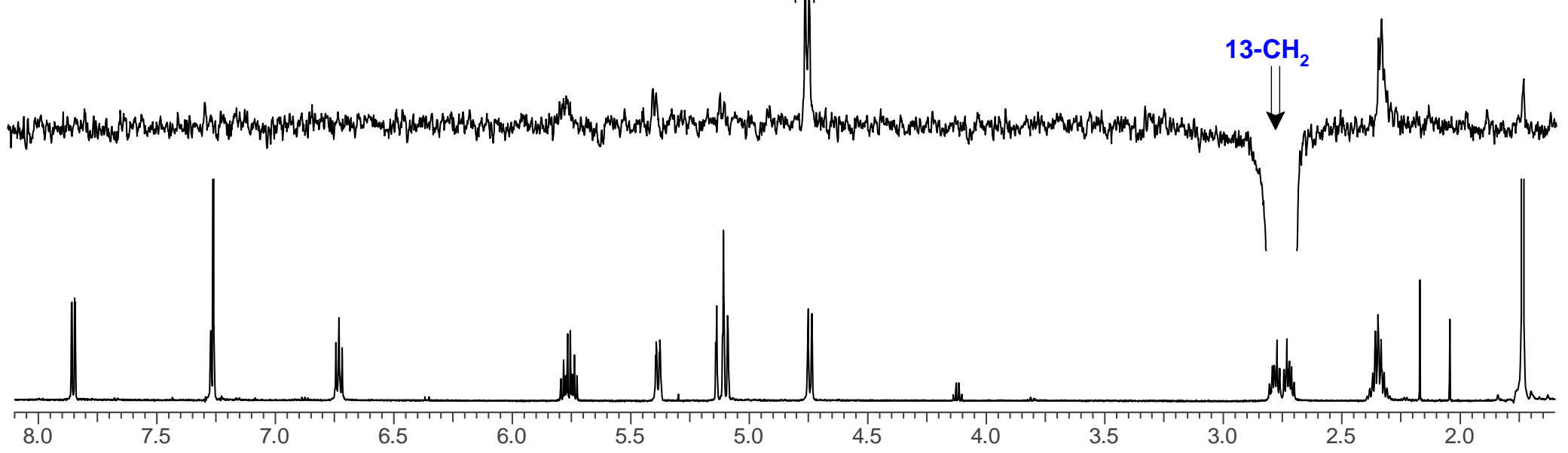

Figure 96: NOE of Compound 205 


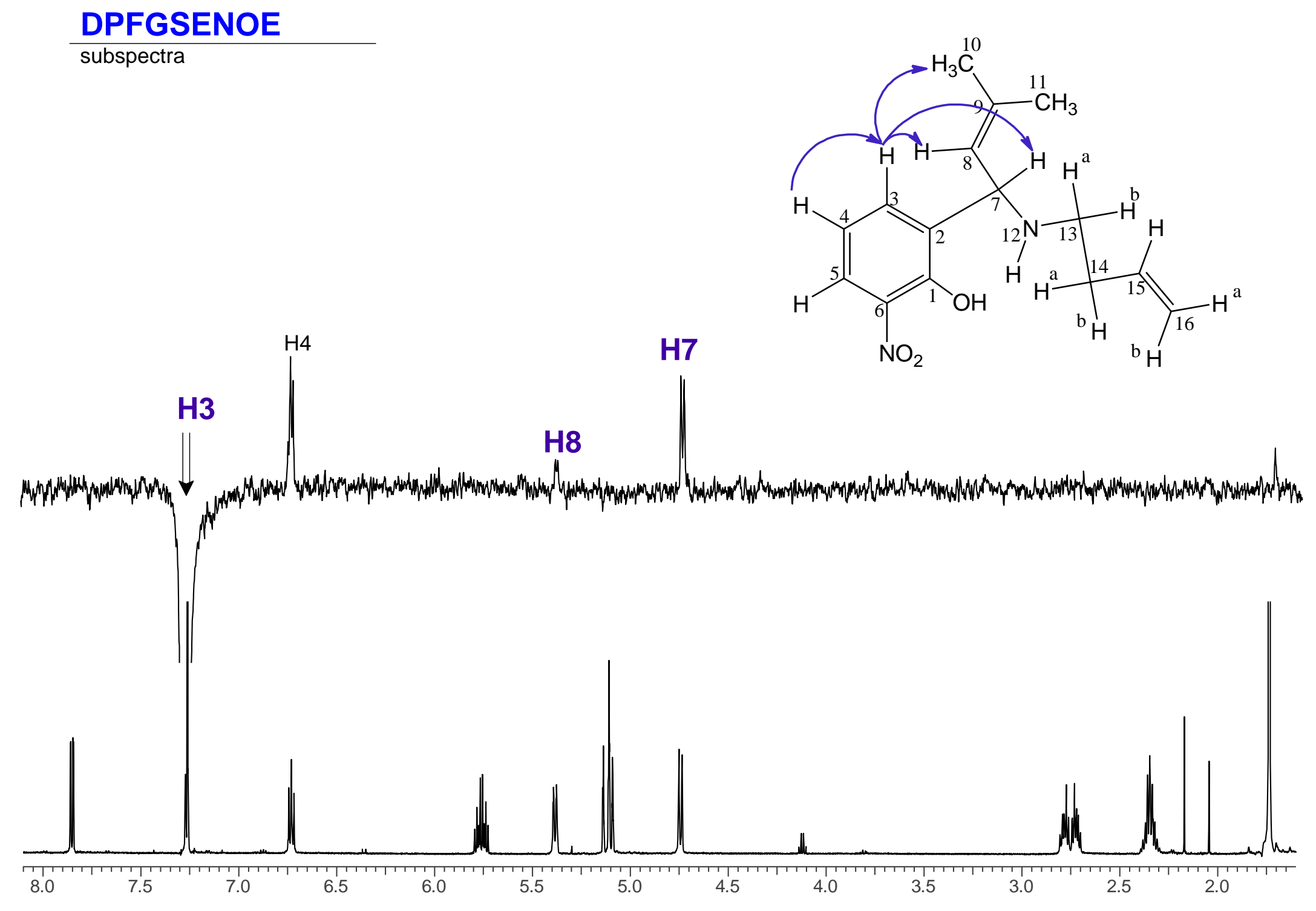

Figure 97: NOE of Compound 205 


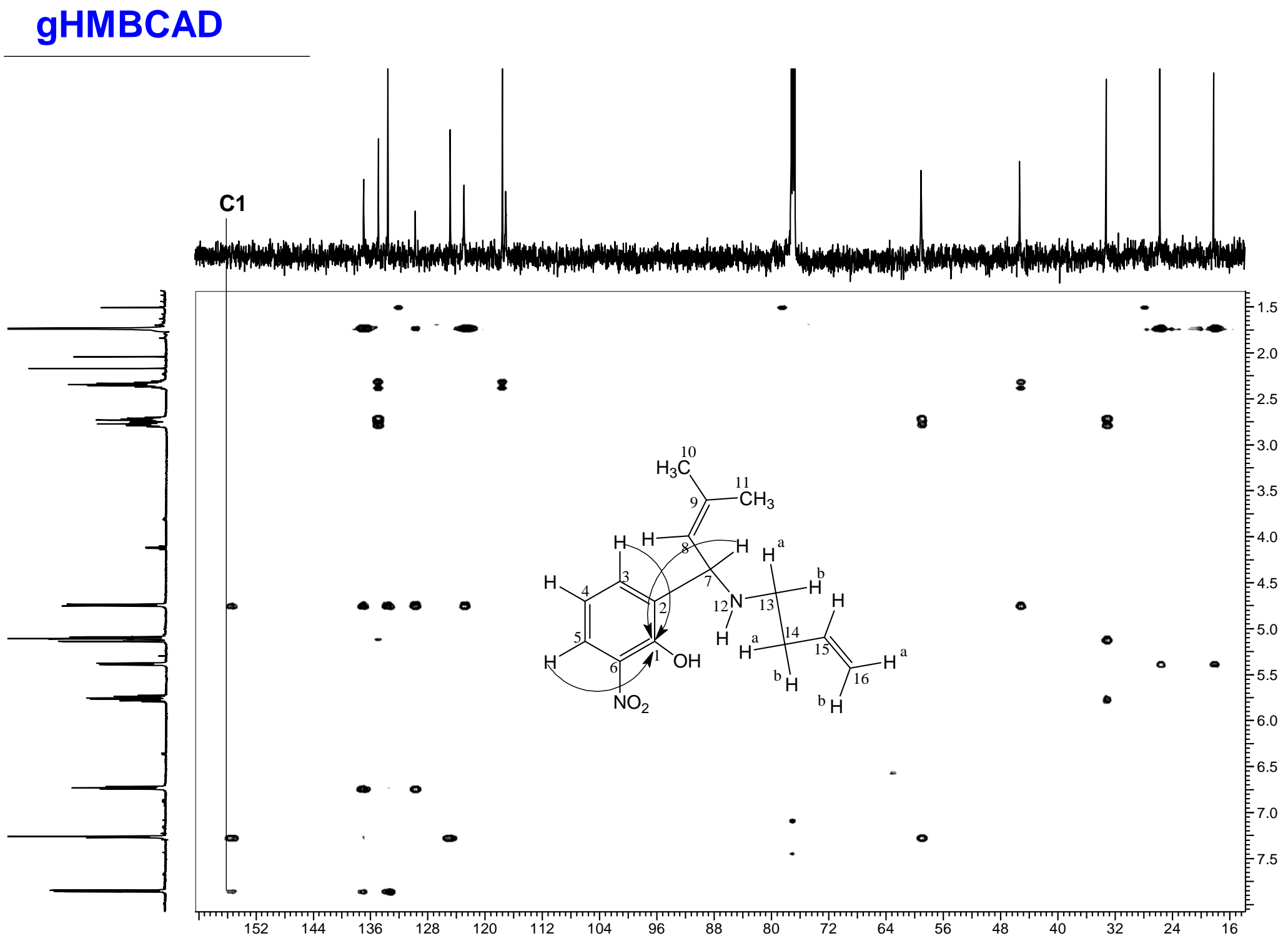

Figure 98: HMBC of Compound 205 


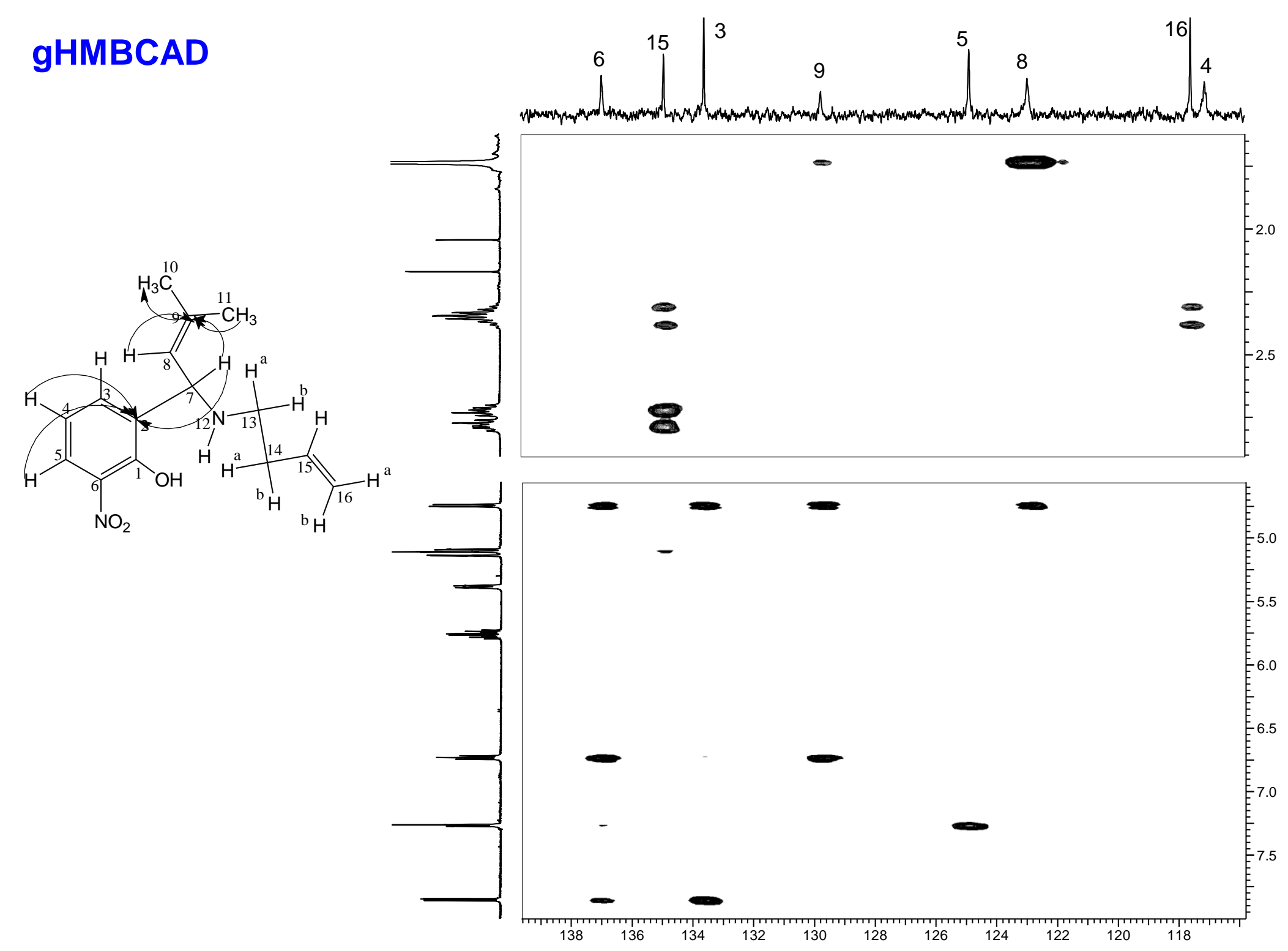

Figure 99: HMBC of Compound $\mathbf{2 0 5}$ 


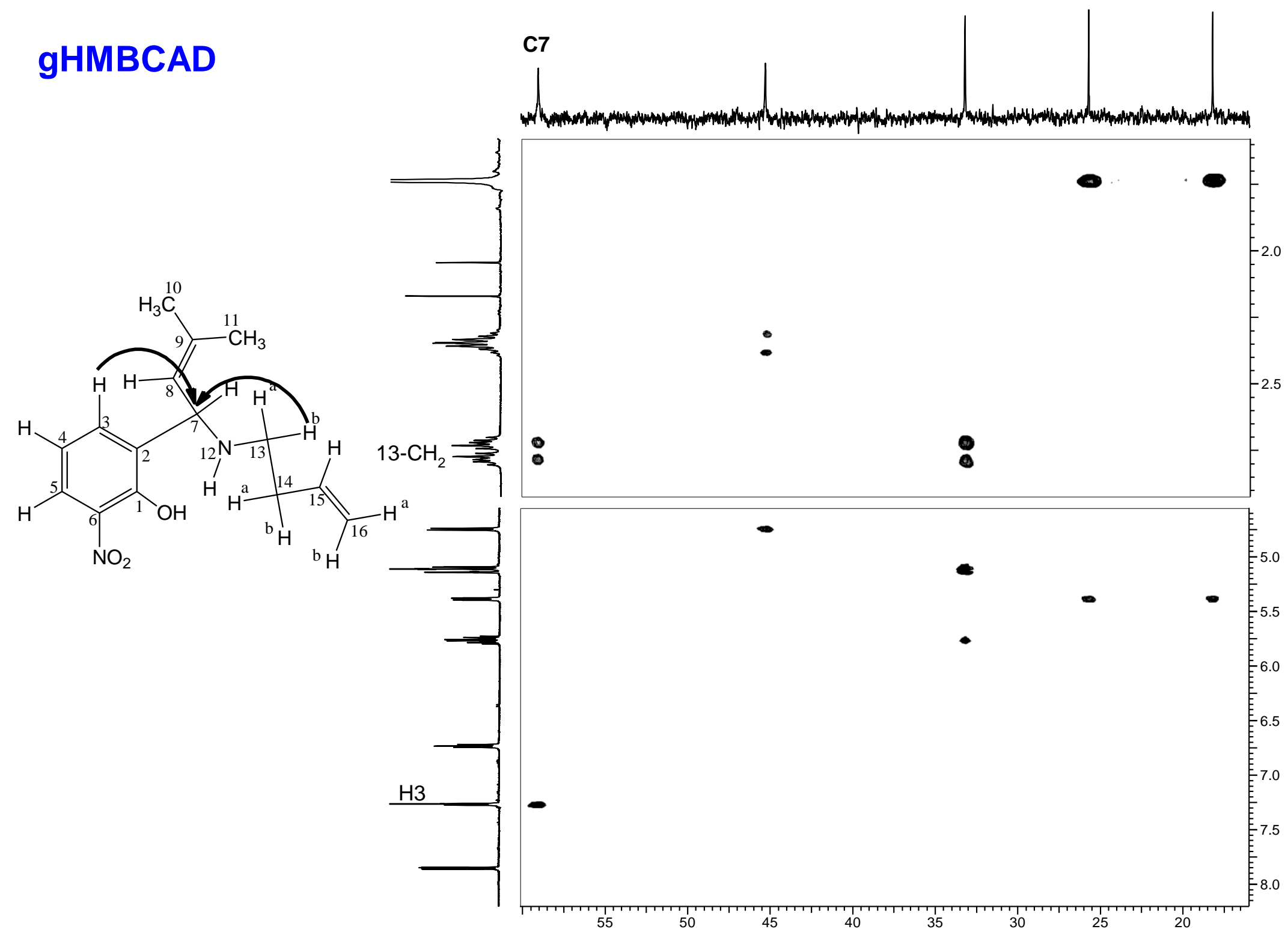

Figure 100: HMBC of Compound 205 